\title{
ENIO MORI
}

Infecção experimental em cavalos pelo herpesvírus eqüino tipo 1: aspectos clínicos e detecção do agente pela reação em cadeia pela polimerase 


\section{ENIO MORI}

\section{Infecção experimental em cavalos pelo herpesvírus eqüino tipo 1: aspectos clínicos e detecção do agente pela reação em cadeia pela polimerase}

Tese apresentada ao Programa de Pós-graduação em Clínica Veterinária da Faculdade de Medicina Veterinária e Zootecnia da Universidade de São Paulo para obtenção do título de Doutor em Medicina Veterinária

Departamento:

Clínica Médica

Área de concentração:

Clínica Veterinária

Orientador:

Prof. Dr. Wilson Roberto Fernandes

São Paulo 
Autorizo a reprodução parcial ou total desta obra, para fins acadêmicos, desde que citada a fonte.

DADOS INTERNACIONAIS DE CATALOGAÇÃO-NA-PUBLICAÇÃO

(Biblioteca da Faculdade de Medicina Veterinária e Zootecnia da Universidade de São Paulo)

T. 1458 Mori, Enio

FMVZ Infecção experimental em cavalos pelo herpesvírus eqüino tipo 1: aspectos clínicos e detecção do agente pela reação em cadeia pela polimerase / Enio Mori. - São Paulo : E. Mori, 2005.

$159 \mathrm{f.}:$ il.

Tese (doutorado) - Universidade de São Paulo. Faculdade de Medicina Veterinária e Zootecnia. Departamento de Clínica Médica, 2005.

Programa de Pós-graduação: Clínica Veterinária.

Área de concentração: Clínica Veterinária.

Orientador: Prof. Dr. Wilson Roberto Fernandes.

1. Eqüinos. 2. Rinopneumonite animal. 3. Herpesviridae. 4. DNA viral. 5. Reação em cadeia por polimerase. I. Título. 


\section{UNIVERSIDADE DE SÃO PAULO \\ Faculdade de Medicina Veterinária e Zootecnia \\ Cidade Universitária "Armando de Salles Oliveira" \\ Comissão Bioética \\ CERTIFICADO}

Certificamos que o Projeto intitulado "Infecção experimental em cavalos pelo herpesvírus equino tipo 1 (HVE-1): estudo das manifestações clínicas e deteç̧ão do agente pela reação em cadeia pela polimerase (PCR)" Protocolo $\mathrm{n}^{\circ} 240 / 2002$, utilizando 10 cavalos, sob a responsabilidade do Prof. Dr. Wilson Roberto Fernandes, está de acordo com os princípios éticos de experimentação animal da Comissão de Bioética da Faculdade de Medicina Veterinária e Zootecnia da Universidade de São Paulo e foi aprovado em reunião de $11 / 12 / 2002$.

(We certify that the Research "Experimental infection in horses with equine herpesvirus 1 (HVE-1): evaluation of clinical signs and detection of virus by polymerase chain reaction (PCR)" protocol number 240/2002, utilizing 10 horses, under the responsability of Prof. Dr. Wilson Roberto Fernandes, agree with Ethical Principles in Animal Research adopted by Bioethic Commision of the Faculty of Veterinary Medicine and Zootechny of University of São Paulo and was approved in 12/11/2002 meeting.)

São Paulo, 12 de dezembro de 2002

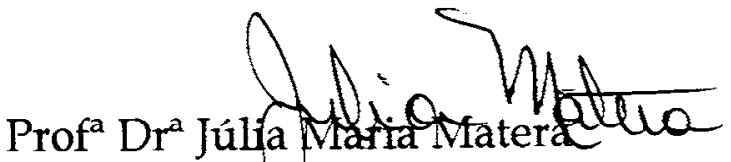

Presidente da Comissão de Bioética FMVZ/USP 


\section{FOLHA DE AVALIAÇÃO}

Nome: MORI, Enio

Título: Infecção experimental em cavalos pelo herpesvírus eqüino tipo 1: aspectos clínicos e detecção do agente pela reação em cadeia pela polimerase

Tese apresentada ao Programa de Pós-graduação em Clínica Veterinária da Faculdade de Medicina Veterinária e Zootecnia da Universidade de São Paulo para obtenção do título de Doutor em Medicina Veterinária

Data:

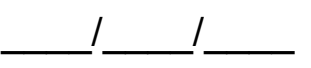

Banca Examinadora

Prof. Dr.

Assinatura:

Prof. Dr.

Assinatura:

Prof. Dr.

Assinatura:

Prof. Dr.

Assinatura:

Prof. Dr.

Assinatura:
Instituição:

Julgamento:

Instituição:

Julgamento:

Instituição:

Julgamento:

Instituição:

Julgamento:

Instituição:

Julgamento: 
Não basta ensinar ao homem uma especialidade porque se tornará assim uma máquina utilizável e não uma personalidade. É necessárío que adquira um sentimento, um senso prático daquilo que vale a pena ser empreendido, daquito que é belo, do que é moralmente correto.

Albert Einstein 
À minha esposa Claudia, que me auxiliou em todas as etapas desta tese. Agradeço a sua dedicação, companheirismo, carinho e espírito crítico sempre com muito bom humor mesmo nas horas mais difíceis.

Ao Prof. Dr.Wilson Roberto Fernandes, pela orientação, amizade e confiança. 


\section{AGRADECIMENTOS}

À Fundação de Amparo à Pesquisa (FAPESP), auxílio pesquisa processo no 02/12599-0, em nome do Prof. Dr.Wilson Roberto Fernandes, que me proporcionou o suporte financeiro necessário para este projeto.

Ao Conselho Nacional de Desenvolvimento Científico e Tecnológico (CNPq), processo nº 140342/04-4, pela concessão da bolsa de doutorado.

À Dra. Sílvia Maria Gomes Massironi pela amizade, pelas sugestões e imprescindível auxílio na confecção do trabalho, pelos ensinamentos, pela receptividade e paciência e pela utilização das instalações e equipamentos do seu laboratório.

À Dra. Maria do Carmo Custódio de Souza Hunold Lara pela execução das provas de isolamento e de sorodiagnóstico para o HVE-1. Também pela gentileza de fornecer a amostra de HVE-1 utilizada na inoculação nos cavalos.

À Profa. Dra. Maria Lúcia Zaidan Dagli pela utilização das instalações e equipamentos do laboratório de Oncologia Experimental.

Aos meus colegas do Laboratório de Oncologia Experimental José Luis, Ivone e Heidge pela cooperação nos meus primeiros passos na biologia molecular.

À Profa. Dra. Dolores Ursula Mehnert pelas preciosas sugestões a esse trabalho.

À Regina Mieko Sakata Mirandola, pelo exemplo de dignidade e determinação.

Ao Prof. Dr. Fernando José Benesi pelos ensinamentos transmitidos, incentivo e pela utilização das instalações e equipamentos dos Laboratórios de Pesquisa do Departamento de Clínica Médica.

Ao Prof. Dr. Enrico Lippi Ortolani, pelos conselhos, pelo incentivo e pela utilização das instalações e equipamentos do Laboratório de Doenças Nutricionais do Departamento de Clínica Médica, que tornaram possível a consecução deste trabalho.

À Profa. Dra. Alice Maria Melville de Paiva Della Libera pela amizade e pelo auxílio no desenvolvimento do presente trabalho. 
Aos demais docentes do Departamento de Clínica Médica da Faculdade de Medicina Veterinária e Zootecnia da Universidade de São Paulo, pelos ensinamentos e pela oportunidade da realização deste trabalho.

Ao Prof. Dr. José Luis Guerra pela leitura das lâminas dos exames histopatológicos.

Ao funcionário Cícero Antônio da Silva pela amizade, auxílio nas colheitas e na manipulação dos animais.

Às funcionárias Claudia Regina Stricagnolo e Maria Luisa Franchini pelo auxílio na execução dos hemogramas.

À Thais Marques pela valiosa colaboração que possibilitou a realização dos experimentos com os camundongos.

À Marieta Trancoso, pelo precioso auxílio nas correções ortográficas e gramaticais desta tese e pela amizade.

À Gláucia Fernandes, pelo auxílio na correção do "abstract".

Aos funcionários Marcos, Clara, Marly, Edna e Maria Helena pela agradável convivência, solidariedade e auxílio na realização deste trabalho.

Aos Médicos Veterinários Residentes e estagiários da área de Clínica e Cirurgia de Grandes Animais, pelo auxílio nas colheitas das amostras e no exame clínico dos animais.

Ao Prof. Dr. Francisco Gacek, Renaide Ferreira e José Victor de Oliveira, pela oportunidade de realizar os experimentos na Estação Experimental de Colina, que resultaram no trabalho da minha qualificação.

Ao Laboratório Biovet S.A. pela doação da vacina Equibort.

Aos colegas do curso de pós-graduação e da UniABC Celso, Marta, Alexandre, Sandra, Lílian, Carla Belli, Neimar, Pierre, Camila, Jean, José Ricardo, Flávio, Aline, João Batista Cruz, Juarez, Cibele Carvalho, Regina, Paula Bastos e Fernando pelo convívio por todos estes anos.

A todos que de alguma forma contribuíram para a realização desta tese. 


\section{RESUMO}

MORI, E. Infecção experimental em cavalos pelo herpesvírus eqüino tipo 1: aspectos clínicos e detecção do agente pela reação em cadeia pela polimerase. [Experimental infection in horses with equine herpesvirus 1: evaluation of clinical signs and detection of virus by polymerase chain reaction]. 2005. $159 \mathrm{f}$. Tese (Doutorado em Medicina Veterinária) - Faculdade de Medicina Veterinária e Zootecnia, Universidade de São Paulo, São Paulo, 2005.

Dez cavalos adultos clinicamente saudáveis foram inoculados por via intranasal com a estirpe A4/72 do herpesvírus eqüino tipo 1 (HVE-1). Com o intuito de estudar o efeito da dose infectante na severidade da rinopneumonite, os animais foram distribuídos em dois grupos experimentais: (a) grupo I (10 $\left.0^{6,6} \mathrm{DICT}_{50}\right)$ e (b) grupo II $\left(5 \times 10^{6,6} \mathrm{DICT}_{50}\right)$. Nos primeiros dez dias após a inoculação viral, todos os cavalos apresentaram manifestações de infecção respiratória leve e restrita às vias aéreas anteriores. Poucos animais desenvolveram leucopenia sangüínea envolvendo linfócitos $(n=4)$ e neutrófilos $(n=2)$. Somente em um houve aumento na contagem dos neutrófilos no lavado broncoalveolar (LBA). Apesar de possuírem elevados títulos de anticorpos neutralizantes antes da inoculação, alguns cavalos apresentaram soroconversão após o desafio viral. Esse padrão de resposta humoral foi determinado pelo aumento da dose infectante. O HVE-1 não foi isolado a partir das secreções nasais de nenhum animal. Entretanto, o DNA viral foi detectado pela reação em cadeia pela polimerase (PCR) nas células mononucleares sangüíneas entre o terceiro e o oitavo dias pós-inoculação (d.p.i.) em todos os animais, indicando a ocorrência de viremia. Além disso, a prova de PCR detectou o vírus nas amostras de LBA a partir do nono d.p.i. no grupo II, demonstrando que a disseminação do HVE-1 pelo trato respiratório após o desafio viral foi dosedependente. Com base nos resultados obtidos, foi possível concluir que a PCR é uma técnica com alta sensibilidade para o diagnóstico do HVE-1, capaz de detectar a presença do DNA viral mesmo quando não ocorre a constatação do agente pelos métodos tradicionais.

Palavras-chave: Eqüinos. Rinopneumonite animal. Herpesviridae. DNA viral. Reação em cadeia por polimerase. 


\begin{abstract}
MORI, E. Experimental infection in horses with equine herpesvirus 1: evaluation of clinical signs and detection of virus by polymerase chain reaction. [Infecção experimental em cavalos pelo herpesvírus eqüino tipo 1: aspectos clínicos e detecção do agente pela reação em cadeia pela polimerase]. 2005, 159 f. Tese (Doutorado em Medicina Veterinária) - Faculdade de Medicina Veterinária e Zootecnia, Universidade de São Paulo, São Paulo, 2005.
\end{abstract}

Ten clinically healthy adult horses were inoculated intranasally with the A4/72 strain of equine herpesvirus 1 (EHV-1). The animals were divided into two experimental groups in order to study the influence of the infective dose in the severity of rhinopneumonitis: (a) group I $\left(10^{6.6} \mathrm{TCID}_{50}\right)$ and (b) group II $\left(5 \times 10^{6.6} \mathrm{TCID}_{50}\right)$. In the first ten days after the inoculation, they showed signs of a mild, self-limiting upper respiratory tract infection. Very few animals developed transient blood leukopenia, involving lymphocytes $(n=4)$ as well as neutrophils $(n=2)$. Only one horse had an increase in the neutrophils count of the bronchoalveolar lavage (BAL) samples. In spite of the presence of neutralizing antibodies before the trial, seroconversion was observed in some horses. The pattern of antibody response was determined by the increase of the challenge exposure. The virus was not isolated from nasal swabs of any horse. However, the EHV-1 was detected through the polymerase chain reaction (PCR) from peripheral blood mononuclear cells (PBMC) of all horses in the experiment within the third to the eighth day after the inoculation that illustrated the viremia. In addition, the PCR assay also detected the virus in BAL samples starting on the ninth day after the experimental infection of group II. For that reason, the dissemination of the EHV-1 throughout the respiratory tract after virus exposure was dose-dependent. Based on the results obtained from this study, it can be affirmed that the PCR is a highly effective technique in detecting the EHV-1. It may be used in circumstances where traditional methods are not efficient due to the fact that it provides an enhanced diagnostic procedure for underdiagnosed diseases.

Key words: Equine. Animal rhinopneumonitis. Herpesviridae. Viral DNA. Polymerase chain reaction. 


\section{LISTA DE FIGURAS}

Figura 1 Representação esquemática da origem hipotética do herpesvírus eqüino tipo 1 (HVE-1)

Figura 2 Representação esquemática da reação em cadeia pela polimerase (PCR) ........

Figura 3 Seqüência de nucleotídeos (sentido $5^{\prime} \rightarrow 3^{\prime}$ ) representativa da região do gene que codifica a glicoproteína $\mathrm{B}(\mathrm{gB})$ do herpesvírus equino tipo 1 (HVE-1) determinada pelos oligonucleotídeos iniciadores (primers) FC2 (senso), RC (anti-senso) e R1 (anti-senso)

Figura 4 Seqüência de nucleotídeos (sentido $5^{\prime} \rightarrow 3^{\prime}$ ) representativa da região do gene que codifica a timidina quinase (tk) do herpesvírus eqüino tipo 1 (HVE-1) determinada pelos oligonucleotídeos iniciadores (primers) tkF1 (senso), tkR2 (anti-senso) e tkF3 (senso)

Figura 5 Representação esquemática das etapas da detecção do herpesvírus eqüino tipo 1 (HVE-1), pela reação em cadeia pela polimerase (PCR)

Figura 6 Fotomicrografia de células do lavado broncoalveolar de cavalo. Em destaque: macrófagos inativos. Coloração de Rosenfeld. Microscopia óptica de imersão, aumento $1000 \times$

Figura 7 Fotomicrografia de células do lavado broncoalveolar de cavalo. Em destaque: macrófago contendo partícula fagocitada no interior do citoplasma. Coloração de Rosenfeld. Microscopia óptica de imersão, aumento 1000×

Figura 8 Fotomicrografia de células do lavado broncoalveolar de cavalo. Em destaque: 1. macrófago contendo neutrófilo fagocitado no interior do citoplasma; 2. linfócito; 3. eosinófilo. Coloração de Rosenfeld. Microscopia óptica de imersão, aumento $1000 \times$

Figura 9 Fotomicrografia de células do lavado broncoalveolar de cavalo. Em destaque: macrófago espumoso. Coloração de Rosenfeld. Microscopia óptica de imersão, aumento $1000 \times$

Figura 10 Fotomicrografia de células do lavado broncoalveolar de cavalo. Em destaque: célula gigante multinucleada. Coloração de Rosenfeld. Microscopia óptica, aumento $400 \times$

Figura 11 Fotomicrografia de células do lavado broncoalveolar de cavalo. Em destaque: 1. macrófago; 2. linfócito; 3 . neutrófilo; 4. eosinófilo. Coloração de Rosenfeld. Microscopia óptica, aumento $400 \times$

Figura 12 Fotomicrografia de células do lavado broncoalveolar de cavalo. Em destaque: presença de grande número de eosinófilos. Coloração de Rosenfeld. Microscopia óptica, aumento $400 \times$ 
Figura 13 Eletroforese em gel de agarose a 1,5\% corado com brometo de etídio. Produtos amplificados com tamanho de $226 \mathrm{pb}$ obtidos com oligonucleotídeos iniciadores (primers) para a região do gene do herpesvírus eqüino tipo 1 (HVE-1) que codifica a timidina quinase (tk). PM: padrão de peso molecular de 100pb. 1: controle negativo. 2 a 4: amostras positivas do sangue de cavalos. 5 a 8: amostras positivas de lavado broncoalveolar (LBA) de cavalos. 9: vacina Equibort ${ }^{\circledR}$ Biovet. 10: amostra padrão A4/72. 11: vacina derivada da estirpe viral Army 183

Figura 14 Eletroforese em gel de agarose a 1,5\% corado com brometo de etídio. Produtos amplificados com tamanho de $460 \mathrm{pb}$ obtidos com oligonucleotídeos iniciadores (primers) para a região do gene do herpesvírus eqüino tipo 1 (HVE-1) que codifica a glicoproteína B (gB). PM: padrão de peso molecular de 100pb. 1: controle negativo. 2 a 4 : amostras positivas do sangue de cavalos. 5 a 8: amostras positivas de lavado broncoalveolar (LBA) de cavalos. 9: vacina Equibort ${ }^{\circledR}$ Biovet. 10: amostra padrão $A 4 / 72$. 11: vacina derivada da estirpe viral Army 183

Figura 15 Eletroforese em gel de poliacrilamida a $8 \%$ corado com nitrato de prata. Produtos amplificados com tamanho de $460 \mathrm{pb}$ obtidos com oligonucleotídeos iniciadores (primers) para a região do gene do herpesvírus eqüino tipo 1 (HVE-1) que codifica a glicoproteína B (gB). PM: padrão de peso molecular de 100pb. 1: amostra "fracamente" positiva de lavado broncoalveolar (LBA) de cavalo. 2: amostra negativa de LBA de cavalo. 3: controle negativo. 4 e 5: amostras positivas de sangue de cavalo. 6 e 7: amostras negativas (reações inespecíficas) de sangue de cavalo. 8: vacina Equibort ${ }^{\circledR}$ Biovet. 9: amostra padrão A4/72. 10: vacina derivada da estirpe viral Army 183

Figura 16 Camundongo inoculado com o herpesvírus eqüino tipo 1 (HVE-1) apresentando conjuntivite mucopurulenta

Figura 17 Camundongos inoculados com o herpesvírus eqüino tipo 1 (HVE-1) apresentando apatia e arqueamento do dorso

Figura 18 Camundongo inoculado com o herpesvírus eqüino tipo 1 (HVE-1) apresentando severa dispnéia

Figura 19 Camundongos inoculados com o herpesvírus eqüino tipo 1 (HVE-1) apresentando quadro convulsivo

Figura 20 Camundongo inoculado com o herpesvírus eqüino tipo 1 (HVE-1) apresentando diminuição na propriocepção 


\section{LISTA DE QUADROS}

Quadro 1 Principais herpesvírus de alguns membros da família Equidae

Quadro 2 Propriedades biológicas e moleculares dos herpesvírus eqüídeos tipo 1 (HVE-1), tipo 4 (HVE-4), tipo 8 (HVE-8) e tipo 9 (HVE-9) .........................

Quadro 3 Dados de levantamentos sorológicos de eqüinos infectados pelo herpesvírus eqüino tipo 1 (HVE-1) em diferentes regiões do Brasil

Quadro 4 Descrição dos cavalos utilizados nos experimentos. São Paulo, 2004

Quadro 5 Oligonucleotídeos iniciadores (primers) selecionados para a reação em cadeia pela polimerase (PCR) para a identificação do herpesvírus eqüino tipo 1 (HVE-1)

Quadro 6 Condições de temperatura e de tempo selecionadas para o ciclo da reação em cadeia pela polimerase (PCR), utilizando oligonucleotídeos iniciadores (primers) para a região do gene que codifica a glicoproteína $\mathrm{B}(\mathrm{gB})$ do herpesvírus eqüino tipo 1 (HVE-1)

Quadro 7 Condições de temperatura e de tempo selecionadas para o ciclo da reação em cadeia pela polimerase (PCR), utilizando oligonucleotídeos iniciadores (primers) para a região do gene que codifica a timidina quinase (tk) do herpesvírus eqüino tipo 1 (HVE-1).

Quadro 8 Achados macroscópicos observados no exame endoscópico das vias aéreas anteriores de cavalos dos grupos experimentais I e II, no período anterior (dia 0) à inoculação com o herpesvírus eqüino tipo 1 (HVE-1). São Paulo, 2004

Quadro 9 Achados macroscópicos observados no exame endoscópico das vias aéreas anteriores de cavalos dos grupos experimentais I e II, no quinto dia pósinoculação com o herpesvírus eqüino tipo 1 (HVE-1). São Paulo, 2004

Quadro 10 Contagem dos leucócitos sangüíneos totais de cavalos dos grupos experimentais I e II inoculados com o herpesvírus eqüino tipo 1 (HVE-1). Os resultados foram expressos em número de células $/ \mathrm{mm}^{3}$. São Paulo, 2004

Quadro 11 Contagem diferencial dos neutrófilos sangüíneos de cavalos dos grupos experimentais I e II inoculados com o herpesvírus eqüino tipo 1 (HVE-1). Os resultados foram expressos em número de células $/ \mathrm{mm}^{3}$ (valor absoluto). São Paulo, 2004

Quadro 12 Contagem diferencial dos linfócitos sangüíneos de cavalos dos grupos experimentais I e II inoculados com o herpesvírus eqüino tipo 1 (HVE-1). Os resultados foram expressos em número de células $/ \mathrm{mm}^{3}$ (valor absoluto). São Paulo, 2004

Quadro 13 Contagem diferencial dos monócitos sangüíneos de cavalos dos grupos experimentais I e II inoculados com o herpesvírus eqüino tipo 1 (HVE-1). Os resultados foram expressos em número de células $/ \mathrm{mm}^{3}$ (valor absoluto). São Paulo, 2004

Quadro 14 Contagem diferencial dos eosinófilos sangüíneos de cavalos dos grupos experimentais I e II inoculados com o herpesvírus eqüino tipo 1 (HVE-1). Os resultados foram expressos em número de células $/ \mathrm{mm}^{3}$ (valor absoluto). São Paulo, 2004 
Quadro 15 Contagem diferencial dos basófilos sangüíneos de cavalos dos grupos experimentais I e II inoculados com o herpesvírus eqüino tipo 1 (HVE-1). Os resultados foram expressos em número de células $/ \mathrm{mm}^{3}$ (valor absoluto). São Paulo, 2004

Quadro 16 Títulos de anticorpos soroneutralizantes contra o herpesvírus eqüino tipo 1 (HVE-1) em soros sangüíneos de cavalos dos grupos experimentais I e II. Os resultados foram expressos em $\log _{10}$. São Paulo, 2004

Quadro 17 Contagem diferencial (\%) dos macrófagos alveolares de cavalos dos grupos experimentais I e II inoculados com o herpesvírus eqüino tipo 1 (HVE-1). São Paulo, 2004

Quadro 18 Contagem diferencial (\%) dos linfócitos alveolares de cavalos dos grupos experimentais I e II inoculados com o herpesvírus eqüino tipo 1 (HVE-1). São Paulo, 2004

Quadro 19 Contagem diferencial (\%) dos neutrófilos alveolares de cavalos dos grupos experimentais I e II inoculados com o herpesvírus eqüino tipo 1 (HVE-1). São Paulo, 2004

Quadro 20 Contagem diferencial (\%) dos eosinófilos alveolares de cavalos dos grupos experimentais I e II inoculados com o herpesvírus eqüino tipo 1 (HVE-1). São Paulo, 2004

Quadro 21 Contagem diferencial (\%) dos mastócitos alveolares de cavalos dos grupos experimentais I e II inoculados com o herpesvírus eqüino tipo 1 (HVE-1). São Paulo, 2004

Quadro 22 Detecção do herpesvírus eqüino tipo 1 (HVE-1) proveniente de amostras do lavado broncoalveolar (LBA) de cavalos pela reação em cadeia pela polimerase (PCR), utilizando oligonucleotídeos iniciadores (primers) para a região do gene que codifica a timidina quinase (tk). São Paulo, 2004

Quadro 23 Detecção do herpesvírus eqüino tipo 1 (HVE-1) proveniente de amostras de sangue de cavalos pela reação em cadeia pela polimerase (PCR), utilizando oligonucleotídeos iniciadores (primers) para a região do gene que codifica a timidina quinase (tk). São Paulo, 2004

Quadro 24 Detecção do herpesvírus eqüino tipo 1 (HVE-1) proveniente de amostras do lavado broncoalveolar (LBA) de cavalos pela reação em cadeia pela polimerase (PCR), utilizando oligonucleotídeos iniciadores (primers) para a região do gene que codifica a glicoproteína B (gB). São Paulo, 2004

Quadro 25 Detecção do herpesvírus eqüino tipo 1 (HVE-1) proveniente de amostras de sangue de cavalos pela reação em cadeia pela polimerase (PCR), utilizando oligonucleotídeos iniciadores (primers) para a região do gene que codifica a glicoproteína B (gB). São Paulo, 2004 


\section{LISTA DE TABELAS}

Tabela 1 Variação da temperatura corpórea $\left({ }^{\circ} \mathrm{C}\right)$ de cavalos dos grupos experimentais I e II inoculados com o herpesvírus eqüino tipo 1 (HVE-1). Os resultados foram expressos em média \pm desvio padrão $(n=5)$. São Paulo, 2004

Tabela 2 Contagens total e diferencial do leucograma de cavalos do grupo experimental I inoculados com o herpesvírus eqüino tipo 1 (HVE-1). Os resultados foram expressos em média \pm desvio padrão do número de células $/ \mathrm{mm}^{3}$ (valor absoluto), n=5. São Paulo, 2004

Tabela 3 Contagem total e diferencial do leucograma de cavalos do grupo experimental II inoculados com o herpesvírus eqüino tipo 1 (HVE-1). Os resultados foram expressos em média \pm desvio padrão do número de células $/ \mathrm{mm}^{3}$ (valor absoluto), n=5. São Paulo, 2004

Tabela 4 Títulos de anticorpos soroneutralizantes contra o herpesvírus eqüino tipo 1 (HVE-1) em soros sangüíneos de cavalos do grupo experimental I. Os resultados foram expressos em média \pm desvio padrão $\left(\log _{10}\right), n=5$. São Paulo, 2004

Tabela 5 Títulos de anticorpos soroneutralizantes contra o herpesvírus eqüino tipo 1 (HVE-1) em soros sangüíneos de cavalos do grupo experimental II. Os resultados foram expressos em média \pm desvio padrão $\left(\log _{10}\right), n=5$. São Paulo, 2004

Tabela 6 Contagem diferencial de células alveolares de cavalos do grupo experimental I inoculados com o herpesvírus eqüino tipo 1 (HVE-1). Os resultados foram expressos em média \pm desvio padrão da porcentagem de macrófagos, linfócitos, neutrófilos, eosinófilos e mastócitos, $(n=5)$. São Paulo, 2004 ...............

Tabela $7 \quad$ Contagem diferencial de células alveolares de cavalos do grupo experimental II inoculados com o herpesvírus eqüino tipo 1 (HVE-1). Os resultados foram expressos em média \pm desvio padrão da porcentagem de macrófagos, linfócitos, neutrófilos, eosinófilos e mastócitos, (n=5). São Paulo, 2004

Tabela 8 Peso corpóreo (g) de camundongos dos grupos controle e experimental (inoculados com o herpesvírus eqüino tipo 1). Os resultados foram expressos em média \pm desvio padrão. São Paulo, 2004 


\section{LISTA DE GRÁFICOS}

Gráfico 1 Representação da variação da temperatura corpórea $\left({ }^{\circ} \mathrm{C}\right)$ de cavalos do grupo experimental I inoculados com o herpesvírus eqüino tipo 1 (HVE-1). Os resultados foram expressos em média \pm desvio padrão $(n=5)$. São Paulo, 2004

Gráfico 2 Representação da variação da temperatura corpórea $\left({ }^{\circ} \mathrm{C}\right)$ de cavalos do grupo experimental II inoculados com o herpesvírus eqüino tipo 1 (HVE-1). Os resultados foram expressos em média \pm desvio padrão $(n=5)$. São Paulo, 2004

Gráfico 3 Contagem dos leucócitos sangüíneos totais de cavalos do grupo experimental I inoculados com o herpesvírus eqüino tipo 1 (HVE-1). Os resultados foram expressos em número de células $/ \mathrm{mm}^{3}$. São Paulo, 2004

Gráfico 4 Contagem dos leucócitos sangüíneos totais de cavalos do grupo experimental II inoculados com o herpesvírus eqüino tipo 1 (HVE-1). Os resultados foram expressos em número de células $/ \mathrm{mm}^{3}$. São Paulo, 2004

Gráfico 5 Contagem diferencial dos neutrófilos sangüíneos de cavalos do grupo experimental I inoculados com o herpesvírus eqüino tipo 1 (HVE-1). Os resultados foram expressos em número de células $/ \mathrm{mm}^{3}$ (valor absoluto). São Paulo, 2004

Gráfico 6 Contagem diferencial dos neutrófilos sangüíneos de cavalos do grupo experimental II inoculados com o herpesvírus eqüino tipo 1 (HVE-1). Os resultados foram expressos em número de células $/ \mathrm{mm}^{3}$ (valor absoluto). São Paulo, 2004

Gráfico 7 Contagem diferencial dos linfócitos sangüíneos de cavalos do grupo experimental I inoculados com o herpesvírus eqüino tipo 1 (HVE-1). Os resultados foram expressos em número de células $/ \mathrm{mm}^{3}$ (valor absoluto). São Paulo, 2004

Gráfico 8 Contagem diferencial dos linfócitos sangüíneos de cavalos do grupo experimental II inoculados com o herpesvírus eqüino tipo 1 (HVE-1). Os resultados foram expressos em número de células $/ \mathrm{mm}^{3}$ (valor absoluto). São Paulo, 2004

Gráfico 9 Representação dos títulos de anticorpos soroneutralizantes contra o herpesvírus eqüino tipo 1 (HVE-1) em soros sangüíneos de cavalos do grupo experimental I. Os resultados foram expressos em $\log _{10}$. São Paulo, 2004 ..........

Gráfico 10 Representação dos títulos de anticorpos soroneutralizantes contra o herpesvírus eqüino tipo 1 (HVE-1) em soros sangüíneos de cavalos do grupo experimental II. Os resultados foram expressos em $\log _{10}$. São Paulo, 2004

Gráfico 11 Representação da contagem diferencial (\%) dos macrófagos alveolares de cavalos do grupo experimental I inoculados com o herpesvírus eqüino tipo 1 (HVE-1). São Paulo, 2004

Gráfico 12 Representação da contagem diferencial (\%) dos macrófagos alveolares de cavalos do grupo experimental II inoculados com o herpesvírus eqüino tipo 1 (HVE-1). São Paulo, 2004

Gráfico 13 Representação da contagem diferencial (\%) dos neutrófilos alveolares de cavalos do grupo experimental I inoculados com o herpesvírus eqüino tipo 1 (HVE-1). São Paulo, 2004

Gráfico 14 Representação da contagem diferencial (\%) dos neutrófilos alveolares de cavalos do grupo experimental II inoculados com o herpesvírus eqüino tipo 1 (HVE-1). São Paulo, 2004 


\section{LISTA DE ABREVIATURAS E SIGLAS}

\begin{tabular}{|c|c|}
\hline BHK-21 & rim de hamster neonato \\
\hline $\mathrm{CHCM}$ & concentração de hemoglobina corpuscular média \\
\hline d.p.i. & dias pós-inoculação \\
\hline $\mathrm{DICT}_{50}$ & dose infectante $50 \%$ em cultura de tecidos \\
\hline ECP & efeito citopático \\
\hline E-Derm & fibroblasto eqüino derivado da derme \\
\hline EDTA & ácido etileno-diamino tetracético \\
\hline EFK & rim fetal eqüino \\
\hline EFL & pulmão fetal eqüino \\
\hline FC & fixação de complemento \\
\hline gB & glicoproteína B \\
\hline gG & glicoproteína G \\
\hline $\mathrm{HCM}$ & hemoglobina corpuscular média \\
\hline HE & hematoxilina e eosina \\
\hline HVE-1 & herpesvírus eqüino tipo 1 \\
\hline HVE-2 & herpesvírus eqüino tipo 2 \\
\hline HVE-3 & herpesvírus eqüino tipo 3 \\
\hline HVE-4 & herpesvírus eqüino tipo 4 \\
\hline HVE-5 & herpesvírus eqüídeo tipo 5 \\
\hline HVE-6 & herpesvírus eqüídeo tipo 6 \\
\hline HVE-7 & herpesvírus eqüídeo tipo 7 \\
\hline HVE-8 & herpesvírus eqüídeo tipo 8 \\
\hline HVE-9 & herpesvírus eqüídeo tipo 9 \\
\hline i.c. & intracerebral \\
\hline ICTV & Comitê Internacional de Taxonomia Viral \\
\hline IFI & Imunofluorescência indireta \\
\hline i.n. & intranasal \\
\hline IP & imunoperoxidase \\
\hline LBA & lavado broncoalveolar \\
\hline LTB & lavado traqueobrônquico \\
\hline MDBK & rim de bovino Madin-Darby \\
\hline MEM & meio essencial mínimo \\
\hline $\mathrm{pb}$ & pares de bases \\
\hline PBS & solução fosfatada salina tamponada \\
\hline PCR & reação em cadeia pela polimerase \\
\hline PK-15 & rim de suíno \\
\hline RK-13 & rim de coelho \\
\hline SDS & sulfato dodecil de sódio \\
\hline SFB & soro fetal bovino \\
\hline SN & soroneutralização \\
\hline SPF & livre de patógenos específicos \\
\hline Taq & Thermus aquaticus \\
\hline tk & timidina quinase \\
\hline VCM & volume corpuscular médio \\
\hline VERO & rim de macaco \\
\hline
\end{tabular}




\section{SUMÁRIO}

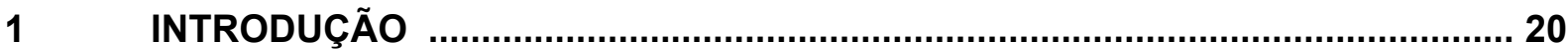

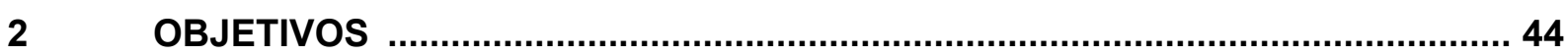

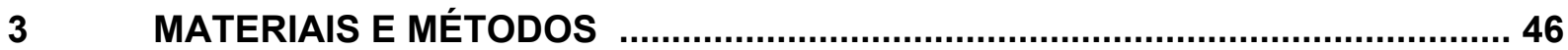

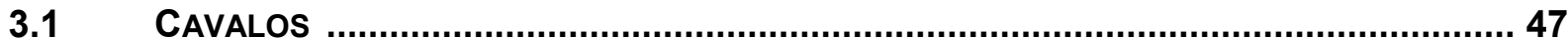

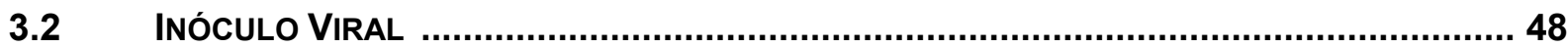

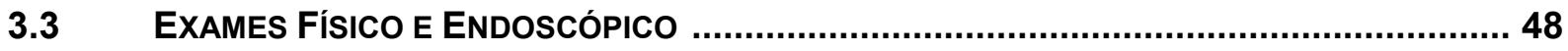

3.4 EXAMES COMPLEMENTARES LABORATORIAIS ................................................. 50

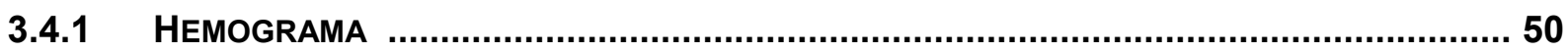

3.4.2 PROVA DE SORODIAGNÓSTICO PARA O HVE-1 ................................................. 51

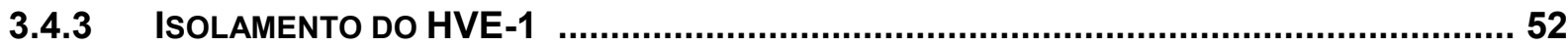

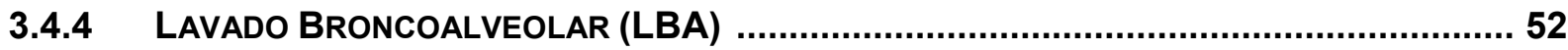

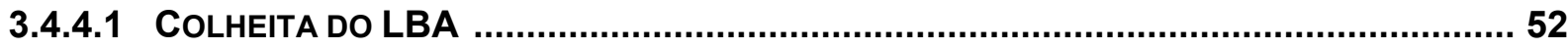

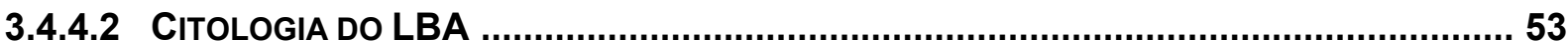

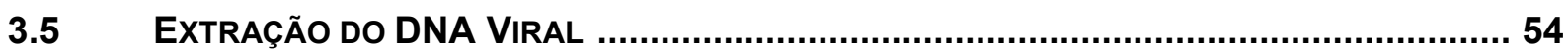

3.5.1 ColHeita de SANGUE PARA EXTRAÇÃo do DNA VIRAL ........................................ 54

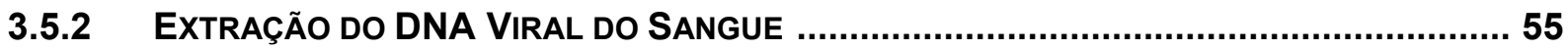

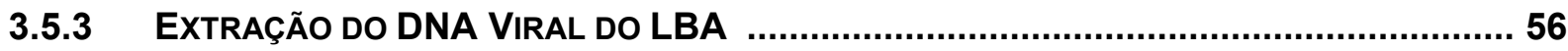

3.6 DetecÇÃo do HVE-1 Pela ReaçÃo em Cadeia Pela Polimerase (PCR) .............. 56

3.7 INFECÇÃo EXPERIMENTAL PELO HVE-1 EM CAMUNDONGOS ................................... 64

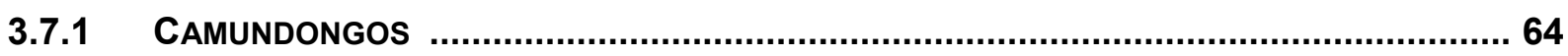

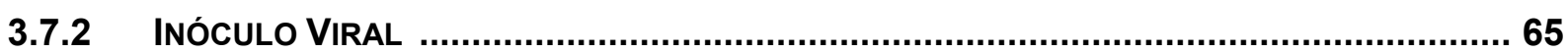

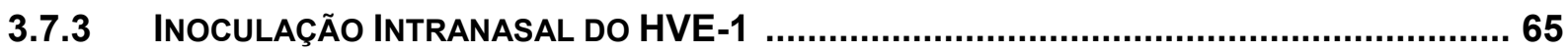

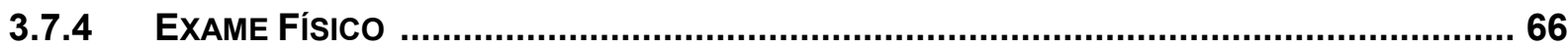

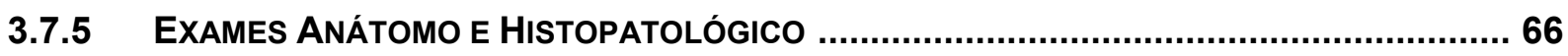

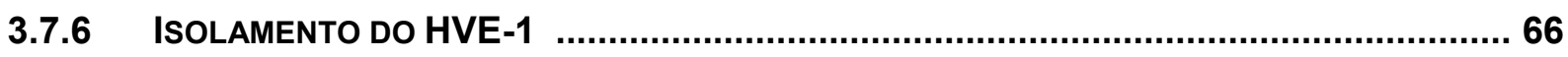

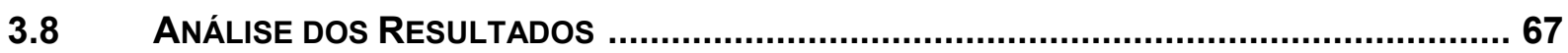

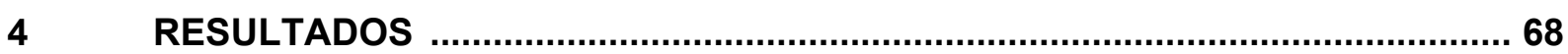

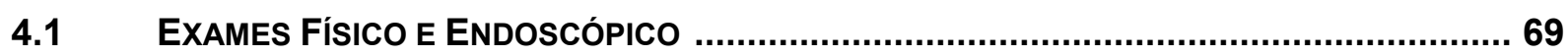

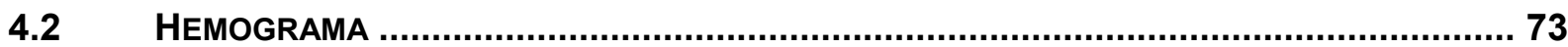

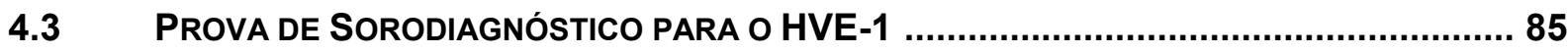

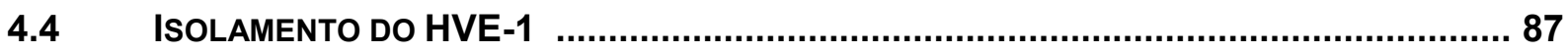

4.5 Citologia do LAVAdo BRoncoALVEOLAR (LBA) .............................................. 87

4.6 DETECÇÃo do dNA VIRAL PELA Eletroforese dos PRodutos dA PCR .............. 98

4.7 INFECÇÃO EXPERIMENTAL PELO HVE-1 EM CAMUNDONGOS .................................. 105

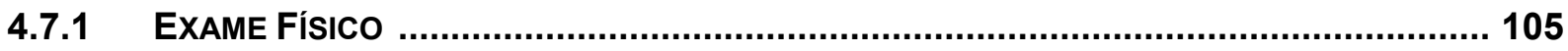

4.7.2 EXAMES ANÁtOMO E Histopatológico ........................................................ 109 


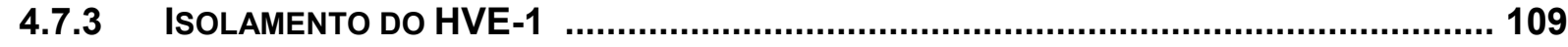

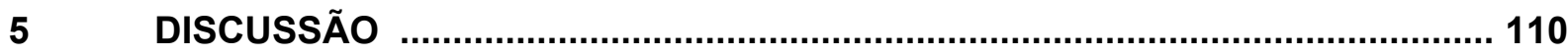

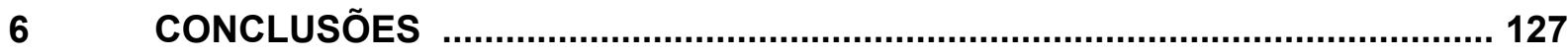

REFERÊNCIAS .................................................................................. 130

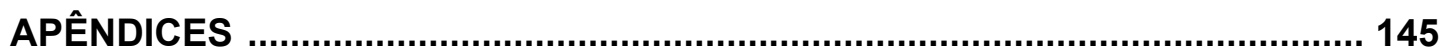

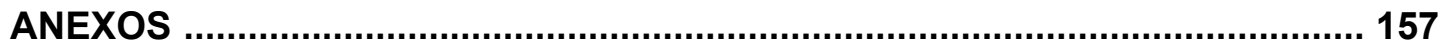


O herpesvírus eqüino tipo 1 (HVE-1) é o agente causador de diferentes formas de doença em cavalos, das quais as mais comuns são a rinopneumonite eqüina, caracterizada por manifestações respiratórias com viremia e pirexia; o abortamento eqüino a vírus, responsável pela mortalidade perinatal de potros e pelo abortamento no terço final da gestação (entre $\circ 8^{\circ}$ e $\circ 11^{\circ}$ meses); e a mieloencefalopatia herpética eqüina, caracterizada por manifestações neurológicas. Além disso, e ainda que com menor freqüência, o HVE-1 pode provocar doenças oculares e genitais e infecção pulmonar vasculotrópica. Essas enfermidades podem ocorrer de forma isolada ou conjunta (ALLEN, 2002a; ALLEN; BRYANS, 1986; CRABB; STUDDERT, 1995; MORI, 2000).

De acordo com o Comitê Internacional de Taxonomia Viral (ICTV), o HVE-1 é um DNA-vírus, envelopado e com capsídeo de simetria icosaédrica, pertencente à família Herpesviridae, subfamília Alphaherpesvirinae e gênero Varicellovirus (MINSON et al., 2000). Seu genoma é linear e consiste de uma fita dupla de DNA de 150.223 pares de bases $(\mathrm{pb})$ de comprimento contendo 76 genes distintos, os quais codificam várias proteínas e glicoproteínas importantes na patogenicidade e imunidade virais (CRABB; STUDDERT, 1995; TELFORD et al., 1992).

Dimock e Edwards (1936), que realizaram um estudo retrospectivo abrangendo o período de 1922 a 1936, foram os pioneiros a citar a ocorrência de surtos de abortamentos causados pelo HVE-1 em éguas nos Estados Unidos da América. O primeiro relato de doença herpética em cavalos no Brasil remonta a 1964, e registra os achados anatomopatológicos de Corrêa e Nilsson em fetos abortados. No entanto, mais dois anos foram necessários para que tais autores isolassem o vírus (NILSSON; CORREAA, 1966). 
Até o presente momento foram identificados nove tipos distintos de herpesvírus que acometem os eqüídeos (Quadro 1). A nomenclatura taxonômica desses tipos foi determinada pela ordem de descoberta ou de classificação como herpesvírus, e nem todos estão relacionados com a manifestação de enfermidades em cavalos (OSTLUND, 1993).

Quadro 1 - Principais herpesvírus de alguns membros da família Equidae

\begin{tabular}{cccc}
\hline Vírus & Sinônimos & Subfamília & Hospedeiro natural \\
\hline HVE-1 & $\begin{array}{c}\text { Vírus da rinopneumonite eqüina ou do } \\
\text { abortamento eqüino } \\
\text { (antigo HVE-1 subtipo 1) }\end{array}$ & $\alpha$ & Equus caballus \\
HVE-2 & Antigo citomegalovírus eqüino & $\gamma$ & Equus caballus \\
HVE-3 & Vírus do exantema coital eqüino & $\alpha$ & Equus caballus \\
HVE-4 & Vírus da rinopneumonite eqüina & $\alpha$ & Equus caballus \\
HVE-5 & Antigo citomegalovírus eqüino & $\gamma$ & Equus caballus \\
HVE-6 & Herpesvírus asinino tipo 1 (HVA-1) & $\alpha$ & Equus asinus \\
HVE-7 & Herpesvírus asinino tipo 2 (HVA-2) & $\gamma$ & Equus asinus \\
HVE-8 & Herpesvírus asinino tipo 3 (HVA-3) & $\alpha$ & Equus asinus \\
HVE-9 & Herpesvírus de gazela tipo 1 (HVG-1) & $\alpha$ & Equus zebra (?) \\
\hline
\end{tabular}

$\alpha$ : Alphaherpesvirinae; $\gamma$ : Gammaherpesvirinae

Fonte dos dados brutos: Minson et al. (2000)

Sabe-se que, embora haja técnicas específicas e bem desenvolvidas para a detecção de anticorpos contra o HVE-1, os resultados podem ser comprometidos em função de reações sorológicas cruzadas com outros herpesvírus de eqüídeos. O 
herpesvírus eqüino tipo 4 (HVE-4), o herpesvírus eqüídeo tipo 8 (HVE-8) e o herpesvírus eqüídeo tipo 9 (HVE-9) apresentam características antigênicas bastante semelhantes àquelas do HVE-1. Conseqüentemente, diferenciá-los pelos métodos de sorodiagnóstico tradicionais com anticorpos policlonais é difícil (BROWNING; FICORILLI; STUDDERT, 1988; CUNHA et al., 2002; FUKUSHI et al., 1997; THOMSON et al., 1976).

O HVE-4 também está relacionado à ocorrência de rinopneumonite em cavalos e mais raramente ao abortamento (OSTLUND, 1993). Devido às similaridades antigênicas e biológicas, até 1981 o HVE-1 e o HVE-4 eram considerados um único agente, denominados subtipos 1 e 2 do HVE-1 (BURROWS; GOODRIDGE, 1975). Com base nos diferentes padrões eletroforéticos do DNA viral obtidos pela endonuclease de restrição, Studdert, Simpson e Roizman (1981) reclassificaram essa divisão do HVE-1 em subtipos 1 e 2 para HVE-1 e HVE-4, respectivamente.

O HVE-8 foi isolado a partir de secreções nasais de jumentos submetidos à imunossupressão experimental com corticosteróides, mas sua relevância como agente infeccioso em eqüinos ainda é desconhecida (BROWNING; FICORILLI; STUDDERT, 1988; CRABB; STUDDERT, 1995). Além da similaridade antigênica entre o HVE-8 e o HVE-1, alguns autores demonstraram elevada homologia genética entre eles, sugerindo que o HVE-1 poderia ser uma variante genética do HVE-8 adaptada à espécie eqüina, após o contato prévio entre populações de jumentos e de cavalos (Fig. 1) (BROWNING; FICORILLI; STUDDERT, 1988; CRABB; STUDDERT, 1995). 


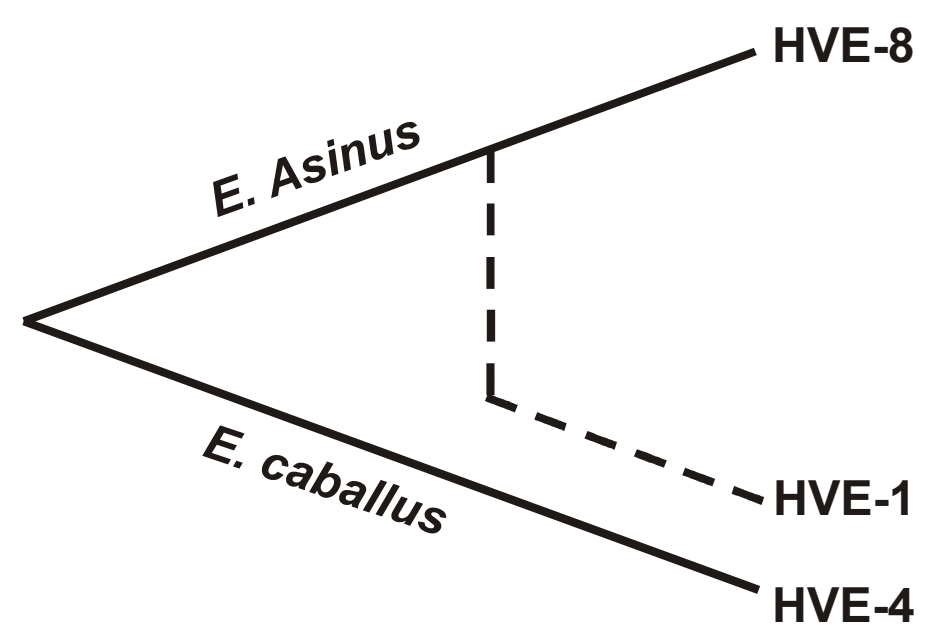

Figura 1 - Representação esquemática da origem hipotética do herpesvírus eqüino tipo 1 (HVE-1)

Fonte dos dados brutos: Crabb e Studdert (1995)

Fukushi et al. (1997) isolaram o HVE-9 a partir de um surto de encefalite epizoótica em gazelas que haviam tido contato prévio com zebras. Os autores observaram considerável similaridade sorológica e genética deste vírus com o HVE-1. A comparação entre as seqüências de bases dos genes das regiões homólogas que codificam as glicoproteínas G (gG) e B (gB) do HVE-9 e do HVE-1 demonstrou que, na análise filogenética, esses vírus são os mais próximos (Quadro 2). Taniguchi et al. (2000) inocularam experimentalmente o HVE-9 em cavalos e verificaram lesões histopatológicas no encéfalo e no pulmão desses animais, sem manifestações neurológicas ou respiratórias compatíveis. As manifestações clínicas observadas por tais pesquisadores eram leves e restringiamse ao trato respiratório anterior, à semelhança das respostas anamnésticas encontradas após sucessivas infecções pelo HVE-1.

De acordo com Allen e Bryans (1986) e Fukushi et al. (1997), os diferentes herpesvírus de eqüídeos apresentam características biológicas - como a patogenicidade no hospedeiro natural, a virulência em camundongos e o isolamento viral em cultivo celular - distintas, o que pode ser observado no Quadro 2. 
Quadro 2 - Propriedades biológicas e moleculares dos herpesvírus eqüídeos tipo 1 (HVE-1), tipo 4 (HVE-4), tipo 8 (HVE-8) e tipo 9 (HVE-9)

\begin{tabular}{|c|c|c|c|c|}
\hline Propriedades & HVE-1 & HVE-4 & HVE-8 & HVE-9 \\
\hline $\begin{array}{l}\text { Patogenicidade no } \\
\text { hospedeiro }\end{array}$ & $\begin{array}{l}\text { Rinopneumonite } \\
\text { Abortamento } \\
\text { Mieloencefalopatia }\end{array}$ & Rinopneumonite & Rinite & Encefalite \\
\hline Tropismo & Endotelial & Não & - & Neuronal \\
\hline $\begin{array}{l}\text { Viremia associada aos } \\
\text { leucócitos }\end{array}$ & Sim & Não & - & Sim \\
\hline Latência & Sim & Sim & Sim & - \\
\hline $\begin{array}{l}\text { Virulência em } \\
\text { camundongo lactente } \\
\text { (i.c.) }\end{array}$ & Sim & Não & - & Sim \\
\hline $\begin{array}{l}\text { Virulência em } \\
\text { camundongo } \\
\text { desmamado (i.n.) }\end{array}$ & $\begin{array}{c}\operatorname{Sim} \\
\text { (pneumonia) }\end{array}$ & Não & - & $\underset{\text { (encefalite) }}{\operatorname{Sim}}$ \\
\hline $\begin{array}{l}\text { Cultivo em células } \\
\text { eqüinas }\end{array}$ & Sim & Sim & Sim & Sim \\
\hline $\begin{array}{l}\text { Cultivo em células não } \\
\text { eqüinas }\end{array}$ & $>15$ tipos & PK-15 & RK-13 & MDBK \\
\hline $\begin{array}{l}\text { Homologia com o HVE-1 } \\
\text { seqüência gB (\%) }\end{array}$ & - & 85,3 & - & 97,5 \\
\hline $\begin{array}{l}\text { Homologia com o HVE-1 } \\
\text { seqüência gG (\%) }\end{array}$ & - & 65,5 & 91,8 & 91,3 \\
\hline
\end{tabular}

i.c.: inoculação intracerebral. i.n.: intranasal

Fonte dos dados brutos: Allen e Bryans (1986); Fukushi et al. (1997)

Estudos comparativos realizados por Patel, Edington e Mumford (1982) em cavalos apontaram diferenças relativas ao tropismo tecidual entre o HVE-1 e o HVE-4. Apesar de ambos os vírus serem detectados no epitélio do trato respiratório e nos macrófagos pulmonares, somente o HVE-1 demonstrou predileção por células endoteliais vasculares do sistema nervoso central e do trato respiratório, bem como por leucócitos sangüíneos circulantes. 
Taniguchi et al. (2000) isolaram o HVE-9 nos leucócitos sangüíneos e na cavidade nasal de cavalos, sugerindo a ocorrência de viremia e de replicação viral no trato respiratório.

A infecção causada pelo HVE-1 em camundongos de quatro semanas de idade inoculados por via intranasal geralmente se restringe ao trato respiratório (AWAN; CHONG; FIELD, 1990; GALOSI et al., 2004; INAZU et al., 1993; WALKER et al., 1998). Relatos da literatura indicam que a virulência do HVE-1 - expressa pela taxa de letalidade e pelo isolamento viral a partir do encéfalo e das vísceras - após a inoculação intracerebral em camundongos lactentes de dois dias de idade varia de acordo com natureza da estirpe viral (NOWOTNY; BURTSCHER; BÜRKI, 1987; PALFI; CHRISTENSEN, 1995; PATEL; EDINGTON, 1983).

Já a inoculação com o HVE-4, além de não provocar manifestações clínicas, não permitiu a detecção de replicações virais nos tecidos de camundongos (AZMI; FIELD, 1993; PALFI; CHRISTENSEN, 1995; PATEL; EDINGTON, 1983).

Para Fukushi et al. (1997), a alta letalidade em camundongos inoculados com o HVE-9 pelas vias intranasal e intracerebral sugere que esse vírus é o mais virulento para a espécie. Os autores observaram manifestações neurológicas e confirmaram o neurotropismo pelos achados histopatológicos e pelo isolamento viral a partir do encéfalo dos animais experimentalmente infectados.

O HVE-1 possui capacidade de replicar-se em uma ampla variedade de células hospedeiras de diferentes origens, tais como: rim de macaco (VERO), rim de bovino Madin-Darby (MDBK), rim de coelho (RK-13), rim de hamster neonato (BHK-21), rim de suíno (PK-15), rim fetal eqüino (EFK), pulmão fetal eqüino (EFL) e fibroblasto eqüino derivado da derme (E-Derm), dentre outras (ALLEN, 2000; CAMPBELL; STUDDERT, 1983; MUMFORD, 1994). Para Crabb e Studdert (1995), 
o comportamento do HVE-8 deve ser semelhante ao do HVE-1, pois também o HVE-8 cresce em linhagens celulares não eqüinas como o RK-13. Já o HVE-4 é mais seletivo, pois se replica apenas em células de origem eqüina e PK-15 (ALLEN, 2000; ALLEN; BRYANS, 1986; CRABB; STUDDERT, 1995). Fukushi et al. (1997) demonstraram que o HVE-9 replica-se em células de origem eqüina e MDBK, provocando efeito citopático.

Como mencionado anteriormente, o HVE-1 é responsável por diferentes enfermidades em cavalos, dentre as quais se destaca a rinopneumonite eqüina, que é considerada uma das mais relevantes causas de doença respiratória viral aguda nessa espécie. Tal moléstia, que apresenta alta morbidade e baixa mortalidade na população de eqüinos, geralmente é negligenciada pelos tratadores porque, na maioria dos casos, suas manifestações clínicas são de caráter leve ou inaparente. No entanto, a rinopneumonite eqüina resulta em consideráveis perdas econômicas quando acomete animais de competição, perdas estas decorrentes do cancelamento das provas, da interrupção de esquemas de treinamento, da diminuição do desempenho atlético e dos altos custos de tratamento - especialmente quando ocorrem complicações bacterianas secundárias (ALLEN; BRYANS, 1986; DONALDSON, 2003).

O HVE-1 distribui-se geograficamente em todos os continentes (ALLEN; BRYANS, 1986). Levantamentos sorológicos realizados nos últimos 16 anos demonstraram que, no Brasil, a infecção pelo HVE-1 em eqüinos está amplamente disseminada, situação que indica o potencial risco de perdas econômicas que esse agente pode ocasionar (Quadro 3). 
Quadro 3 - Dados de levantamentos sorológicos de eqüinos infectados pelo herpesvírus eqüino tipo 1 (HVE-1) em diferentes regiões do Brasil

\begin{tabular}{lcccc}
\hline \multicolumn{1}{c}{ Autores } & $\begin{array}{c}\text { Teste } \\
\text { sorológico }\end{array}$ & \% de positivos & $n$ & Localidade \\
\hline Fernandes (1988) & FC & 67,2 & 586 & SP \\
Modolo et al. (1989) & FC & 17,6 & 250 & SP (noroeste) \\
Kotait et al. (1989a) & SN & 13,5 & 1.178 & SP \\
Kotait et al. (1989b) & SN & $24,3(1986)$ & - & SP (Ribeirão Preto) \\
& SN & $50,0(1987)$ & - & SP (Ribeirão Preto) \\
& SN & $70,0(1988)$ & - & SP (Ribeirão Preto) \\
Vargas e Weiblen (1991) & SN & $40,0(1989)$ & - & SP (Ribeirão Preto) \\
Vasconcellos (1992) & SN & 84,7 & 348 & RS \\
& FC & 88,14 & $59^{*}$ & SP \\
Gama (1992) & FC & 67,3 & $52^{* *}$ & SP \\
& FC & 55 & 300 & SP \\
Lara et al. (2003b) & IP & 92 & 300 & SP \\
Heinemann et al. (2002) & IFI & 92 & 300 & SP \\
& SN & 92,3 & 300 & SP \\
& SN & 17,71 & 96 & SP (noroeste) \\
& SN & 14,3 & 70 & PA (Uruará) \\
& SN & 33,4 & 659 & SP \\
\hline
\end{tabular}

FC: fixação de complemento, SN: soroneutralização, IP: imunoperoxidase, IFI: imunofluorescência indireta

* histórico de abortamento

** sem relatos anteriores de abortamento

Uma vez infectados pelo HVE-1, os eqüinos tornam-se portadores latentes e potenciais fontes de infecção do vírus. O HVE-1 aloja-se nos linfonodos e em células do trato respiratório, nos leucócitos mononucleares - monócitos/macrófagos e linfócitos $T$ - e no nervo trigêmeo, no qual permanece em estado de latência. A reexposição ao vírus ou a sua reativação por fatores estressantes predisponentes podem provocar novas infecções durante toda a vida do animal (EDINGTON; 
BRIDGES; HUCKLE, 1985; EDINGTON; WELCH; GRIFFITHS, 1994; SCOTT; DUTTA; MYRUP, 1983; SLATER et al., 1994; WELCH et al., 1992).

A doença respiratória aguda causada pelo HVE-1 é observada principalmente em potros de até um ano de idade, em infecções primárias. Nesses animais imunologicamente inexperientes, a infecção geralmente acomete as vias aéreas anteriores, manifestando-se sob a forma de rinite e de faringite, com viremia e pirexia (ALLEN; BRYANS, 1986; GIBSON et al., 1992a; OSTLUND, 1993).

As diferentes manifestações clínicas da rinopneumonite eqüina podem ser atribuídas à exposição prévia ao agente infeccioso. Reinfecções pelo HVE-1 em animais adultos geralmente são responsáveis por enfermidade inaparente, pois a multiplicação viral no trato respiratório é reduzida devido à presença de anticorpos neutralizantes protetores (BREATHNACH et al., 2001; BRYANS, 1969; BURROWS; GOODRIDGE, 1975; POWELL; BURROWS; GOODRIDGE, 1974).

Além de variarem em função do grau de imunidade do animal, as manifestações clínicas da infecção causada pelo HVE-1 também podem variar de acordo com a virulência das estirpes virais e a dose infectante. Outros fatores que influenciam a severidade das manifestações clínicas são: presença de infecções bacterianas secundárias, condições climáticas adversas - outono e inverno -, condições estressantes, como alta densidade populacional, transporte, procedimentos cirúrgicos, desmame e exercício intenso em treinamentos e competições (BURROWS; GOODRIDGE, 1975; DONALDSON, 2003; GIBSON et al., 1992a; MUMFORD, 1994; MUMFORD; ROSSDALE, 1980).

A literatura destaca três principais fontes de infecção natural do HVE-1 para cavalos susceptíveis, a saber: (1) animais ativamente infectados, que eliminam o 
vírus nas secreções respiratórias da nasofaringe; (2) fetos abortados e seus envoltórios, ou secreções provenientes do trato reprodutivo de éguas imediatamente após o abortamento; (3) reativação endógena do vírus, que se encontrava em estado quiescente, em indivíduos portadores de infecção latente (ALLEN, 2002b; CRABB; STUDDERT, 1995; KOTAIT, 1991; VAN MAANEN, 2002).

Em estudos epidemiológicos realizados na Austrália, Gilkerson et al. (1999a, 1999b) demonstraram que as éguas são a principal fonte de infecção primária do HVE-1 para potros em fase de lactação, com idade entre 30 e 120 dias. Posteriormente, a disseminação viral para os animais susceptíveis é ampliada pela transmissão entre populações de potros antes e após o desmame. No final desse ciclo, observa-se que quase todos os animais tornaram-se portadores latentes.

O HVE-1 é altamente contagioso e sua transmissão é horizontal, ou seja, ocorre pela inalação de aerossóis provenientes do trato respiratório ou pela ingestão de alimento e água contaminados por secreções (ALLEN, 2002b; ALLEN; BRYANS, 1986; KOTAIT, 1991; MUMFORD, 1994). A transmissão via fômite também pode ocorrer, por exemplo, quando o mesmo endoscópio é utilizado em diversos indivíduos, sem desinfecção prévia (ALLEN, 2002b). Além disso, Carvalho et al. (2000a) apontam o sêmen de garanhões persistentemente infectados como potencial transmissor do HVE-1, durante a cópula ou pela inseminação artificial.

A principal porta de entrada do HVE-1 é a mucosa do trato respiratório, na qual a infecção primária se instala pela multiplicação viral local (ALLEN, 2002b; KOTAIT, 1991; OSTLUND, 1993).

Embora o cavalo seja o principal hospedeiro susceptível à infecção natural pelo HVE-1, relatos da literatura indicam que outros eqüídeos - como jumentos, 
zebras e cavalos selvagens Przewalski - também são susceptíveis à infecção por esse agente (ALLEN, 2000; BORCHERS; FRÖLICH, 1997; BORCHERS; FRÖLICH; LUDWIG, 1999; CRANDELL, 1985; GUPTA et al., 2000). Embora mais raramente, há registros de que algumas espécies não-eqüídeas - como bovinos, Ihamas, alpacas, gazelas e antílopes - foram infectadas pelo HVE-1, desenvolvendo enfermidades como o abortamento e a encefalite (ALLEN, 2000; CRANDELL, DRYSDALE; STEIN, 1979; FUKUSHI et al., 1997).

Quando a rinopneumonite eqüina é experimentalmente induzida em cavalos pela inoculação intranasal do agente viral, o período de incubação oscila, via de regra, entre um e dois dias, mas pode ser maior, estendendo-se algumas vezes por até 10 dias (ALLEN, 2002a; CRANDELL, 1985; FERNANDES, 2001; GIBSON et al., 1992a; OSTLUND, 1993; WALKER; LOVE; WHALLEY, 1999). Segundo Bryans e Allen (1989), essa variação no período de incubação pode estar relacionada à virulência da estirpe do HVE-1 infectante.

Em sua forma respiratória mais severa, a enfermidade caracteriza-se pelo aumento - de intensidade variável - da temperatura corpórea, que pode atingir valores máximos de até $41,1^{\circ} \mathrm{C}$, quadro que pode perdurar por períodos de um a sete dias. A evolução da febre é intermitente, ou seja, os períodos de pirexia são transitórios e de curta duração, e intercalados por períodos normotérmicos. A febre apresenta característica bifásica, e o segundo pico de elevação térmica geralmente coincide com a viremia (ALLEN, 2002a; ALLEN; BRYANS, 1986; BRYANS; ALLEN, 1989; CRANDELL, 1985; OSTLUND, 1993; WALKER; LOVE; WHALLEY, 1999).

A presença de secreção nasal bilateral é o quadro clínico característico e mais constantemente observado na rinopneumonite eqüina. Essa secreção, 
inicialmente serosa, de consistência líquida e de natureza profusa e incolor, contém alta concentração do agente infeccioso. Com a progressão da infecção viral, entre o segundo e o terceiro dias, a secreção evolui rapidamente para mucosa, de consistência mais viscosa, apresentando maior densidade e cor esbranquiçada em virtude da presença de células epiteliais de descamação e de leucócitos inflamatórios, podendo se tornar ressecada ao redor das narinas. Decorridos quatro a cinco dias do início das manifestações clínicas, a infecção bacteriana secundária pode produzir um exsudato nasal mucopurulento bastante viscoso, opaco e de cor amarelada (ALLEN, 2002a; BRYANS; ALLEN, 1989).

Também são observadas conjuntivite - caracterizada pela presença de lacrimejamento leve, com secreção variando de serosa a mucopurulenta - e congestão das mucosas óculo-palpebrais e nasal. Ainda, é possível que o animal atravesse um período transitório de anorexia, depressão e linfoadenopatia, esta última marcada pela sensibilidade e pelo aumento do tamanho dos linfonodos mandibulares e retrofaríngeos (ALLEN, 2000; ALLEN, 2002a; BEECH, 1991; DONALDSON, 2003; GIBSON et al., 1992a; MUMFORD, 1994; POWELL, 1975).

Em casos não complicados, a rinite e a faringite aguda - que são as manifestações clínicas mais comuns causadas pelo HVE-1 no trato respiratório de cavalos - persistem entre uma e duas semanas após o início da infecção (ALLEN, 2002a; GIBSON et al., 1992a).

Ocasionalmente, o HVE-1 pode alcançar as vias aéreas mais distais, causando traqueobronquite, bronquiolite e/ou pneumonite. Além disso, pode ocorrer o desenvolvimento concomitante de infecções bacterianas secundárias, o que implica manifestações clínicas mais severas e compatíveis com broncopneumonia, 
como tosse produtiva, ruídos respiratórios anormais e dispnéia (ALLEN, 2002a; ALLEN; BRYANS, 1986; BEECH, 1991; POWELL, 1991; WALKER; LOVE; WHALLEY, 1999).

No exame endoscópico, as características da infecção pelo HVE-1 são hiperemia, ulcerações e necrose focal na mucosa da nasofaringe, com presença de exsudato purulento na traquéia, além de hiperplasia linfóide faringeana, identificada pelo grande número de folículos linfóides ativos distribuídos na superfície da faringe (PRICKETT, 1970; RAKER, 1982; ROBERTSON, 1991; SUTTON et al., 1998).

Entretanto, diversos autores comentam que, em cavalos adultos com mais de dois anos de idade, que já sofreram infecções sucessivas pelo HVE-1 e possuem altos títulos de anticorpos neutralizantes protetores - responsáveis pela redução da replicação viral no trato respiratório -, tais manifestações clínicas raramente são observadas (ALLEN 2002a; BREATHNACH et al., 2001; BRYANS, 1969; BURROWS; GOODRIDGE, 1975; MORI et al., 2003; MUMFORD; ROSSDALE, 1980; POWELL; BURROWS; GOODRIDGE, 1974).

Durante a fase aguda da infecção viral observam-se também alterações hematimétricas, como a leucopenia por neutropenia e a linfopenia conseqüente à diminuição dos linfócitos T. Já a leucocitose por neutrofilia pode ocorrer devido ao desenvolvimento de infecções bacterianas secundárias. Moderada leucocitose por linfocitose pode aparecer na fase de convalescença da infecção viral, principalmente em decorrência do aumento de células B responsáveis pela produção de anticorpos (ALLEN, 2002a; ALLEN; BRYANS, 1986; BRYANS; ALLEN, 1989; CRANDELL, 1985; MCCULLOCH et al., 1993; MUMFORD; ROSSDALE, 1980; SUTTON et al., 1998; WALKER; LOVE; WHALLEY, 1999). 
Com base na avaliação dos tipos celulares presentes no pulmão e na função dos macrófagos alveolares, alguns autores sugerem que os lavados traqueobrônquico (LTB) e broncoalveolar (LBA) são importantes ferramentas no estudo da patogenia e no auxílio diagnóstico das afecções respiratórias causadas pelo HVE-1 em cavalos (FERNANDES; SANCHES, 2002; KYDD; HANNANT; MUMFORD, 1996; MORI, 2000; MORI et al., 2003).

O HVE-1 infecta macrófagos e linfócitos alveolares, e pode ser responsável pela diminuição dessas células no LBA de cavalos durante a fase aguda da doença. Isso, segundo Kydd, Hannant e Mumford (1996), provavelmente é decorrência da lise das células infectadas pelo vírus, ou do aumento de adesão dos leucócitos ao epitélio broncoalveolar infectado. Concomitantemente à diminuição de células mononucleares, os autores observaram aumento da população de células polimorfonucleares no LBA em resposta à infecção viral.

Fernandes e Sanches (2002) relatam aumento de células epiteliais cilíndricas ciliadas no LTB de cavalos com afecções virais. Tal aumento seria conseqüência da descamação do epitélio respiratório, causada provavelmente pela multiplicação do vírus nesse tipo celular.

Estudando a influência da infecção pelo HVE-1 na função dos macrófagos alveolares de cavalos inoculados experimentalmente, Mori (2000) e Mori et al. (2003) observaram linfocitose no LBA desses animais no $16^{\circ}$ dia pós-inoculação, provavelmente devido à resposta imune dos linfócitos-T contra a infecção viral.

O HVE-1 pode ser recuperado da nasofaringe de potros com primoinfecção por períodos superiores a 12 dias. Já em cavalos adultos sem manifestações clínicas aparentes, a eliminação viral ocorre por um período mais curto - entre 24 a 
48 horas -, e muitas vezes em quantidade insuficiente para produzir efeito citopático no cultivo celular, o que dificulta o isolamento do vírus (ALLEN; BRYANS, 1986; BEECH, 1991; FERNANDES, 2001; MUMFORD; ROSSDALE, 1980; SHARMA et al., 1992; WALKER; LOVE; WHALLEY, 1999).

Segundo Ostlund (1993), a replicação do HVE-1 no interior dos monócitos e dos linfócitos T sangüíneos ocorre durante a fase de viremia, que coincide com a manifestação aguda da doença respiratória. Outros pesquisadores sugerem que o período de maior sucesso para o isolamento do vírus a partir dos leucócitos sangüíneos varia entre quatro e dez dias após o início da doença respiratória (ALLEN, 2002a; BRYANS, 1969). Nesse mesmo período, o HVE-1 também pode ser isolado no tecido linfóide e em diferentes segmentos do trato respiratório posterior (KYDD et al., 1994a; 1994b).

Atualmente, o isolamento viral em cultivo celular é o principal método de detecção do HVE-1 em amostras clínicas, tais como secreções da cavidade nasal, sangue e fetos abortados. Esse método é considerado eficaz e confiável, mas a obtenção dos resultados demanda um longo período de tempo, e requer quantidade suficiente de vírus viável na amostra para infectar o cultivo celular e promover o efeito citopático (ALLEN, 2000).

A viabilidade do HVE-1 em cultivo celular pode ser prejudicada por diferentes fatores, como por exemplo: colheita de secreções nasais em períodos de baixa eliminação viral ou de fetos abortados em mau estado de conservação, utilização de meios de transporte em condições inadequadas de preservação e presença de contaminantes como bactérias, produtos químicos e toxinas (ALLEN, 2002a; CRABB; STUDDERT, 1995; GALOSI et al., 2001; OSTLUND, 1993). 
Já os métodos sorológicos convencionais, como a fixação de complemento e a soroneutralização, quando utilizados para o diagnóstico de infecções recentes, requerem amostras de soro pareadas da fase aguda - dois a três dias após o aparecimento das manifestações clínicas -, e da fase de convalescença - três a quatro semanas após o início da doença. O resultado é considerado positivo quando ocorre a soroconversão, ou seja, quando os títulos de anticorpos das amostras aumentam pelo menos quatro vezes - ou $\geq 10^{0,6} \mathrm{em}$ log - entre as duas fases (ALLEN, 2000; ALLEN, 2002a; ALLEN; BRYANS, 1986; MORI et al., 2003; THOMSON et al., 1976).

Cavalos adultos pertencentes a uma população na qual o HVE-1 é endêmico são submetidos a sucessivos desafios virais e, conseqüentemente, apresentam elevados títulos de anticorpos séricos neutralizantes por tempo prolongado, muitas vezes perdurando por mais de um ano (DOLL; BRYANS, 1962; MUMFORD, 1994). Em tais casos a soroconversão pode não ocorrer, pois a infecção pelo HVE-1 fica restrita ao trato respiratório anterior dos animais, o que dificulta o isolamento viral a partir das secreções nasais e dos leucócitos sangüíneos (BRYANS, 1969; GIBSON et al., 1992b).

A partir da década de 90 do século $\mathrm{XX}$, estudos voltados à detecção do HVE-1 pela reação em cadeia pela polimerase (PCR) passaram a ser desenvolvidos. Esse método de diagnóstico apresenta algumas vantagens em relação àqueles anteriormente mencionados, como alta sensibilidade e especificidade, rapidez na obtenção dos resultados - entre um e dois dias -, possibilidade de detectar proteínas ou ácido nucléico em amostras nas quais o vírus 
não permanece viável e capacidade de diferenciar os herpesvírus relacionados imunologicamente (ALLEN, 2000).

Assim, e de acordo com a literatura, atualmente a PCR é a técnica mais eficaz para a detecção do HVE-1 em uma ampla variedade de amostras, independentemente de o vírus nelas encontrado estar ou não viável. Experimentos realizados por diferentes pesquisadores, em regiões distintas, demonstraram que a PCR é mais sensível no diagnóstico do HVE-1 em amostras clínicas - como secreções nasais, sangue ou fetos abortados de cavalos - do que o isolamento viral em cultivo celular (BALLAGI-PORDÁNY et al., 1990; GUPTA; SINGH; YADAV, 1996; KIRISAWA et al., 1993; LAWRENCE et al., 1994; SHARMA et al., 1992; STUDDERT et al., 2003; VAN MAANEN et al., 2000; VARASSO et al., 2001; WAGNER et al., 1992). Outros trabalhos apontam a capacidade desse método em determinar a ocorrência de infecção viral latente pelo HVE-1 nos linfonodos, no nervo trigêmeo, nos linfócitos e monócitos sangüíneos, no baço e no tecido pulmonar de cavalos (CARVALHO et al., 2000b; EDINGTON; WELCH; GRIFFITHS, 1994; FOOTE et al., 2004; SLATER et al., 1994; TAOUJl et al., 2002; WELCH et al., 1992).

A PCR também foi utilizada com sucesso por O’Keefe et al. (1994) e Rimstad e Evensen (1993) em investigações retrospectivas sobre a ocorrência de abortamentos causados pelo HVE-1 em éguas a partir de blocos de parafina que continham tecidos fetais eqüinos fixados em formol, e na detecção do HVE-1 em situações nas quais o isolamento viral em cultivo celular era difícil ou impossível devido à natureza das amostras, como por exemplo, órgãos autolisados e sêmen (CARVALHO et al., 2000a; GALOSI et al., 2001; MACKIE et al., 1996). 
Outras aplicações da PCR são a diferenciação entre estirpes naturais e vacinais do HVE-1 (OSTERRIEDER et al., 1994) e a detecção de variações genéticas entre as diferentes estirpes desse vírus (MCCANN; MUMFORD; BINNS, 1995; RIMSTAD; HYLLSETH, 1994).

A PCR é uma técnica enzimática in vitro, originalmente descrita por Mullis e Faloona (1987) e modificada por Saiki et al. (1988), a qual consiste em repetições cíclicas de seqüências específicas de DNA a partir de quantidades mínimas da molécula original, que servem como molde. O processo de amplificação do número de moléculas de DNA apresenta crescimento exponencial, aumentando seletivamente a quantidade original de DNA-alvo em milhões de vezes.

A especificidade da reação é comandada pelo uso de dois oligonucleotídeos, que são pequenas moléculas de fita simples de DNA quimicamente sintetizadas compostas por 18 a 30 nucleotídeos, as quais localizam e delimitam o segmento de DNA a ser amplificado (seqüência-alvo) e atuam como iniciadores (primers) para a extensão do DNA, catalisada pela enzima Thermus aquaticus (Taq) DNA polimerase termoestável. Os dois primers são complementares às duas fitas opostas do DNA, ficando pareados de modo antiparalelo à seqüência-alvo que será amplificada. Conforme mostra a figura 2, os primers são orientados de tal modo que as suas extensões do segmento de DNA constituam um molde em cada novo ciclo. Esse processo envolve repetidos ciclos (20 a 45) de desnaturação pelo calor (92 a $\left.95^{\circ} \mathrm{C}\right)$, hibridização dos primers a uma temperatura mais baixa $\left(37\right.$ a $\left.70^{\circ} \mathrm{C}\right)$ e extensão do DNA pela enzima Taq DNA polimerase $\left(70\right.$ a $\left.72^{\circ} \mathrm{C}\right)$ (BASCUÑANA, 1997; REUBEL; STUDDERT, 1998). 


\section{DNA}

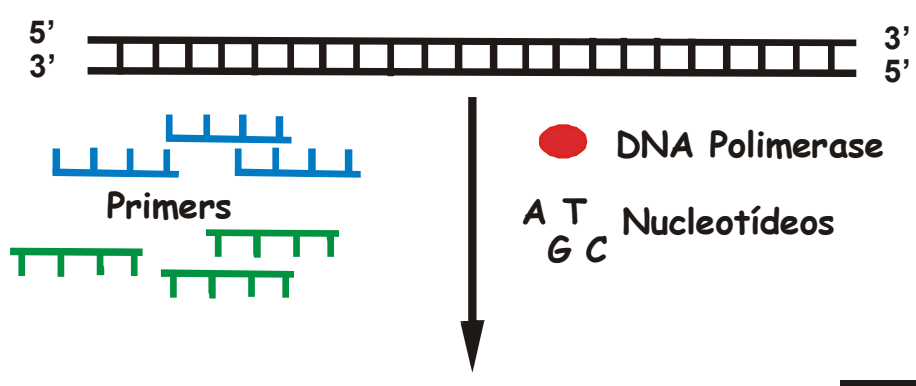

Desnaturação $\left(92\right.$ a $\left.95^{\circ} \mathrm{C}\right)$

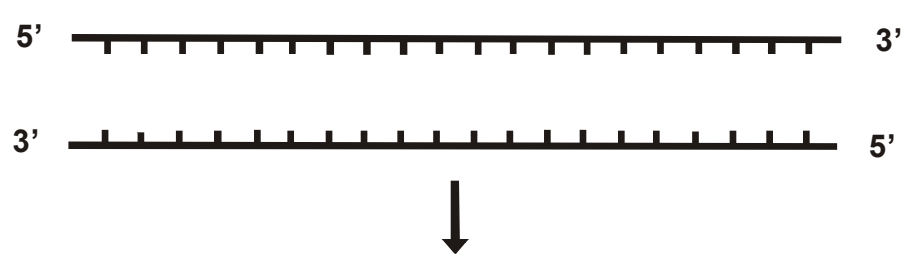

Hibridização dos primers $\left(37\right.$ a $\left.70^{\circ} \mathrm{C}\right)$
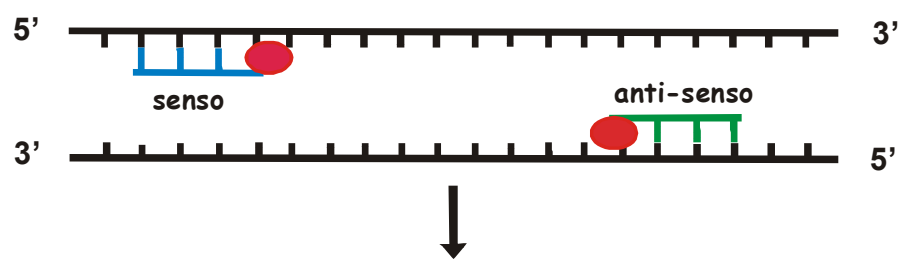

20 a 45

ciclos

Extensão $\left(70\right.$ a $\left.72^{\circ} \mathrm{C}\right)$

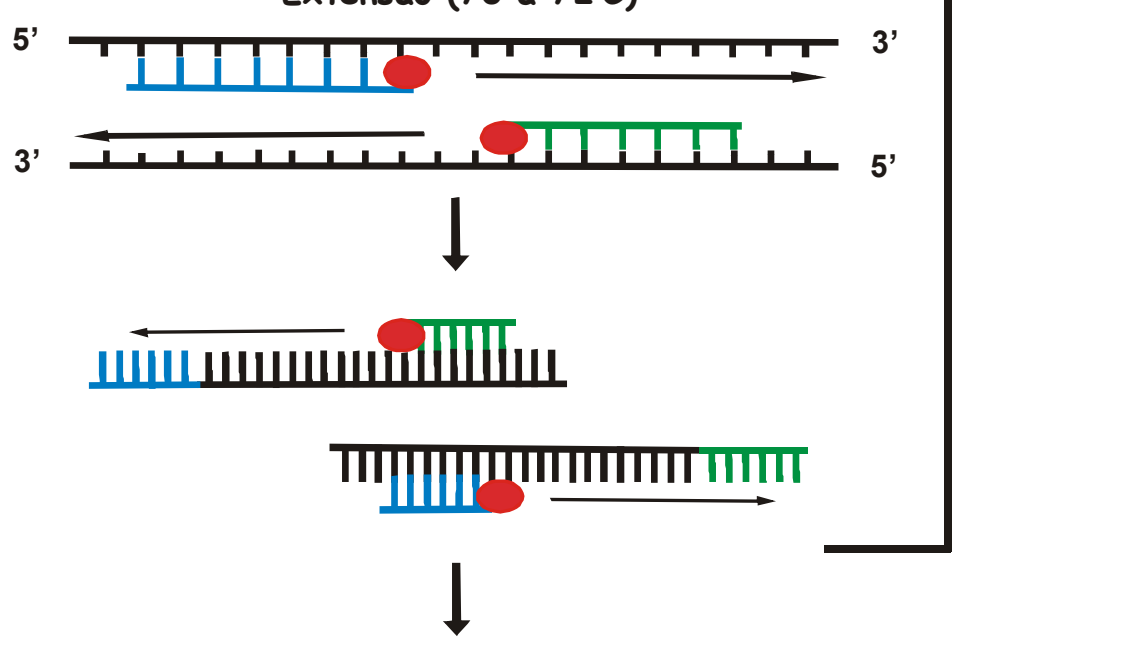

\section{IIIIIIIIIIIIIIIIIII}

IIIIIIIIIIIIIIIIIIII

\section{IIIIIIIIIIIIIIIIIII}

\section{IIIIIIIIIIIIIIIIIIII}

Figura 2 - Representação esquemática da reação em cadeia pela polimerase (PCR) 
Inicialmente, as seqüências de nucleotídeos dos primers foram escolhidas com base nas regiões mais conservadas do genoma viral, que eram comuns entre os diferentes tipos de herpesvírus eqüino e, conseqüentemente, amplificavam produtos do mesmo tamanho, impossibilitando a sua diferenciação. Para confirmar a especificidade e diferenciar os fragmentos de DNA amplificados, os pesquisadores utilizavam técnicas complementares como a hibridização do produto da PCR com sondas de oligonucleotídeos internos específicos (BALLAGI-PORDÁNY et al., 1990; SHARMA et al., 1992), ou a digestão por endonucleases de restrição (O'KEEFE et al., 1991; WELCH et al., 1992).

Posteriormente, Telford et al. (1992) seqüenciaram o genoma completo do HVE-1, e alguns autores realizaram o seqüenciamento parcial do genoma do HVE-4 (NICOLSON; CULLINANE; ONIONS, 1990; NICOLSON; ONIONS, 1990; RIGGIO; CULLINANE; ONIONS, 1989). Em 1998, Telford et al. completaram o seqüenciamento do genoma do HVE-4. A partir desses estudos foi possível selecionar primers específicos, baseados na seqüência de nucleotídeos de regiões divergentes do genoma do HVE-1 e do HVE-4, permitindo assim a diferenciação direta entre eles pela PCR (BORCHERS; SLATER, 1993; KIRISAWA et al., 1993).

Outros autores identificaram a seqüência de nucleotídeos da glicoproteína $\mathrm{G}$ (gG) homóloga do HVE-8 (FICORILLI; STUDDERT; CRABB, 1995), e das glicoproteínas G (gG) e B (gB) homólogas do HVE-9 (FUKUSHI et al., 1997).

Atualmente, uma das provas mais utilizadas para a diferenciação entre os tipos de herpesvírus eqüinos é a nested-PCR, composta por duas etapas de PCR: (1) um fragmento de DNA é amplificado; (2) o fragmento específico de DNA amplificado na primeira etapa é utilizado como molde, mas submetido a um novo par de primers internos (BAXI et al., 1996; BORCHERS; SLATER, 1993; KIRISAWA et 
al., 1993; MACKIE et al., 1996; SLATER et al., 1994; VARASSO et al., 2001). As vantagens desse método são o aumento da sensibilidade em relação à $\mathrm{PCR}$ convencional e a diluição de possíveis inibidores da PCR presentes no DNA-molde original quando da transferência do produto amplificado da primeira etapa para os reagentes de uma nova reação (REUBEL; STUDDERT, 1998).

O desenho dos primers do HVE-1 tomou como base o estudo de pelo menos oito diferentes regiões genômicas, das quais a região gB foi a mais utilizada (REUBEL; STUDDERT, 1998). A seqüência dos nucleotídeos dos primers deve ser derivada de regiões conservadas do genoma, evitando assim falhas de detecção decorrentes das variações naturais ou das adaptações laboratoriais (KIRISAWA et al., 1993; WAGNER et al., 1992).

A glicoproteína B (gB) do HVE-1 desempenha um papel importante na patogenicidade viral, mediando tanto a entrada do vírus no interior da célula hospedeira - via adsorção e penetração - quanto a disseminação do vírus entre as células. Devido à sua localização no envelope viral e na superfície das células infectadas, ela também é importante na imunidade do hospedeiro, sendo o principal alvo dos anticorpos neutralizantes de cavalos convalescentes da infecção herpética. Essa glicoproteína é uma das principais responsáveis pelo compartilhamento das propriedades antigênicas - reações cruzadas - entre os tipos de herpesvírus eqüídeos, conseqüente à similaridade na seqüência dos nucleotídeos e dos aminoácidos (CRABB; STUDDERT, 1995; RIGGIO; CULLINANE; ONIONS, 1989).

A região do gene gB é considerada altamente conservada entre os membros da família Herpesviridae. O alinhamento da seqüência dos nucleotídeos codificantes da região gB dos genomas do HVE-1 e do HVE-4 revelou forte grau de conservação, com cerca de $85 \%$ de homologia. Apesar dessa grande homologia, foram 
detectadas diferentes seqüências de nucleotídeos nessa mesma região dos genomas do HVE-1 e do HVE-4, evidenciadas pelo tamanho dos produtos amplificados (KIRISAWA et al., 1993; WAGNER et al., 1992; WELCH et al., 1992). Já Fukushi et al. (1997) não observaram diferenças entre os produtos obtidos pela PCR do HVE-1 e do HVE-9, devido à grande homologia $(97,5 \%)$ existente entre eles. Nesse caso, para a realização da tipificação viral, foram necessários a clonagem e o seqüenciamento dos nucleotídeos.

Outra região bastante conservada e de alta homologia entre o HVE-1 e o HVE-4 (cerca de 85\%) é aquela que codifica a timidina quinase (tk) (CARVALHO; PASSOS; MARTINS, 2000). A timidina quinase (tk) é uma enzima importante para a patogenicidade do HVE-1, pois atua no estabelecimento de latência e reativação do vírus no hospedeiro (SLATER; GIBSON; FIELD, 1993).

A eficiência e a sensibilidade da PCR podem ser prejudicadas por diversos fatores, como: (1) DNA de baixa qualidade devido à sua degradação ou quebra pela autólise; (2) presença de hemoglobina e de alguns reagentes utilizados na extração do DNA - tais como fenol, EDTA, proteinase $\mathrm{K}$ e dodecil sulfato de sódio (SDS) -, que atuam inibindo a Taq DNA polimerase; (3) concentrações inadequadas dos reagentes, como o $\mathrm{Mg}^{2+}$ - cujo excesso aumenta a ocorrência de amplificações inespecíficas; (4) amplificação de segmentos muito grandes; (5) contaminação cruzada - pequenas quantidades de DNA de uma amostra para outra - na colheita ou na manipulação laboratorial (BASCUNÃNA, 1997; GALOSI et al., 2001; O’KEEFE et al., 1994; REUBEL; STUDDERT, 1998; RIMSTAD; EVENSEN, 1993).

Os métodos empregados na extração do DNA também podem afetar a eficiência da amplificação (GALOSI et al., 2001; RIMSTAD; EVENSEN, 1993). A utilização de técnicas de extração que quebrem a membrana celular e desnaturem 
as proteínas do virion com maior eficiência, melhorando o rendimento e a pureza do DNA - como a digestão pela proteinase $\mathrm{K}$ associada ao fenol-clorofórmio e posterior precipitação pelo etanol - é recomendada por muitos pesquisadores (CARVALHO; PASSOS; MARTINS, 2000; MCCANN; MUMFORD; BINNS, 1995; WAGNER et al., 1992). Técnicas de extração de DNA mais simples, como aquela que preconiza o aquecimento das amostras (BALLAGI-PORDÁNY et al., 1990; GUPTA; SINGH; YADAV, 1996; LAWRENCE et al., 1994; O'KEEFE et al., 1991; OSTERRIEDER et al., 1994; SHARMA et al., 1992) resultam em uma incompleta dissociação entre o DNA e a proteína, o que pode gerar uma PCR menos eficiente (RIMSTAD; EVENSEN, 1993).

Até o presente momento, estudos voltados à utilização de técnicas de PCR para a identificação dos herpesvírus que acometem os eqüinos são escassos e limitados no Brasil. A literatura nacional registra apenas três relatos nos quais os autores detectaram o HVE-1 em diferentes tipos de amostras clínicas, tais como secreções nasais, sangue, sêmen, órgãos de animais provenientes de abatedouros e tecidos de fetos abortados (CARVALHO; PASSOS; MARTINS, 2000; CARVALHO et al., 2000a; CARVALHO et al., 2000b). Além disso, a aplicação de técnicas de PCR para o estabelecimento de um diagnóstico rápido e preciso nos casos de rinopneumonite eqüina ainda não foi adequadamente explorada. Outro aspecto que merece atenção é o fato de não existirem dados disponíveis sobre a ocorrência de outros tipos do herpesvírus eqüídeos no país (CARVALHO et al., 2000b; CUNHA et al., 2002). Desta forma, e tendo em vista a relevância do HVE-1 como agente causador de enfermidades em cavalos - e as perdas econômicas delas decorrentes -, as investigações sobre técnicas que facilitem o diagnóstico desse agente em animais infectados revestem-se de grande importância. 
2 Objetivos 
Os objetivos do presente trabalho foram:

2.1 Analisar, por meio de exames físico e endoscópico, as manifestações clínicas da rinopneumonite em cavalos inoculados com a estirpe A4/72 do HVE-1.

2.2 Investigar possíveis alterações decorrentes da infecção pelo HVE-1 no hemograma desses animais.

2.3 Pesquisar a resposta de anticorpos soroneutralizantes em cavalos, após o desafio viral.

2.4 Verificar a ocorrência de infecção respiratória pelo HVE-1 por meio do isolamento viral em cultivo de células VERO, a partir das secreções nasais dos cavalos inoculados.

2.5 Avaliar citologicamente a composição e a morfologia dos tipos celulares presentes no lavado broncoalveolar (LBA) de cavalos, antes e após a inoculação com o HVE-1.

2.6 Detectar pela reação em cadeia pela polimerase $(\mathrm{PCR})$, a presença de DNA viral em amostras do LBA e de sangue de cavalos inoculados com o HVE-1.

2.7 Comparar os resultados obtidos pelas provas de sorodiagnóstico e de isolamento viral com aqueles da PCR. 
3 Materiais e Métodos 


\subsection{Cavalos}

Foram utilizados 10 cavalos (Equus caballus) adultos - oito machos e duas fêmeas -, sem raça definida, com idade e peso corpóreo variando de 8 a 16 anos e de 332 a 462kg, respectivamente (Quadro 4).

Quadro 4 - Descrição dos cavalos utilizados nos experimentos. São Paulo, 2004

\begin{tabular}{ccccc}
\hline Animal & \multicolumn{4}{c}{ Características Individuais } \\
\cline { 2 - 5 } & Idade (anos) & Peso $(\mathrm{kg})$ & Pelagem & Sexo \\
\hline 01 & 16 & 415 & Castanha & Macho Castrado \\
02 & 08 & 355 & Pampa & Fêmea \\
03 & 12 & 452 & Alazão & Macho Castrado \\
04 & 16 & 372 & Castanha & Macho Castrado \\
05 & 16 & 405 & Alazão & Macho Castrado \\
06 & 12 & 395 & Castanha & Fêmea \\
08 & 15 & 428 & Castanho & Macho Castrado \\
09 & 16 & 420 & Alazão & Macho Castrado \\
10 & 10 & 462 & Alazão & Macho Castrado \\
& 09 & 332 & Castanho & Macho Castrado \\
\hline
\end{tabular}

Os animais foram alojados em baias individuais com dimensões de $3,5 \times 3,5 \mathrm{~m}$, isoladas do atendimento clínico, pertencentes ao Setor de Clínica de Eqüinos do Departamento de Clínica Médica da Faculdade de Medicina Veterinária e Zootecnia da Universidade de São Paulo. A alimentação para cada animal foi composta por $4 \mathrm{~kg}$ de ração peletizada comercial para eqüinos e $4 \mathrm{~kg}$ de feno, divididos em duas vezes ao dia, e a água oferecida ad libitum. A cama utilizada nas baias foi a maravalha de pinus, trocada diariamente. As condições de alojamento e de 
manutenção dos animais, bem como os procedimentos experimentais adotados, estão de acordo com a Comissão de Bioética da Faculdade de Medicina Veterinária e Zootecnia da Universidade de São Paulo, e seguem as recomendações descritas no Canadian Council Animal Care (1993).

No início dos experimentos, nenhum dos animais utilizados apresentava manifestações clínicas respiratórias, ou de qualquer outro sistema orgânico, compatíveis com a infecção causada pelo HVE-1. Não havia histórico de vacinação ou infecção experimental prévia por esse agente.

Os cavalos foram distribuídos em dois grupos experimentais, a saber: (I) animais (01 a 05) inoculados com 1ml da suspensão viral; (II) animais (06 a 10) inoculados com $5 \mathrm{ml}$ da suspensão viral.

\subsection{INÓCULO VIRAL}

Foi utilizado o HVE-1, derivado da amostra padrão de vírus A4/72 (Instituto Biológico de São Paulo, São Paulo - SP), originalmente isolado de feto eqüino abortado (REINER et al., 1972) e cultivado por 15 passagens em células VERO. O inóculo viral de desafio foi de $10^{6,6} \mathrm{DICT}_{50} / \mathrm{ml}$ (dose infectante $50 \%$ em cultura de tecidos) do HVE-1 por instilação intranasal direta nos turbinados rostrais da narina direita de cada cavalo (MORI, 2000; MORI et al., 2003).

\subsection{EXAMES Físico E ENDOSCÓPICO}

Todos os animais foram submetidos ao exame físico duas vezes ao dia. Esse exame contemplou primeiramente o exame geral dos sistemas orgânicos e, em 
seguida, o exame específico do sistema respiratório, com a utilização dos meios semiológicos para a deteç̧ão das manifestações clínicas. O exame físico foi realizado diariamente durante a fase aguda da infecção pelo HVE-1, ou seja, até dez dias após a inoculação.

No exame físico geral foram avaliadas as mucosas aparentes - bucal, nasal e óculo-palpebrais -, em relação à sua coloração. Além disso, os linfonodos mandibulares foram inspecionados e palpados para avaliação de consistência, mobilidade, tamanho, forma, sensibilidade e temperatura. Observou-se também o estado geral dos animais em relação ao comportamento e foram mensuradas as funções vitais: freqüências respiratória e cardíaca e temperatura corpórea (DIRKSEN; GRÜNDER; STÖBER, 1993; GIBSON et al., 1992a; SPEIRS, 1997).

No exame físico específico do sistema respiratório foram observados o tipo e a intensidade dos movimentos respiratórios e a duração relativa da inspiração e da expiração. Foram pesquisados ruídos de origem respiratória que pudessem ser escutados externamente, como tosse, espirros ou estridores. Em relação às secreções nasal e ocular, foram observadas características como coloração, consistência, odor, quantidade e localização (uni ou bilateral). Na palpação da traquéia e da laringe foram pesquisadas a sensibilidade local, o reflexo da tosse e os frêmitos. O exame do tórax teve como objetivo verificar a presença ou não de frêmitos pela palpação ou alterações de sons pela percussão. Posteriormente foi realizada a auscultação da traquéia e do tórax, com o intuito de pesquisar a presença de ruídos respiratórios anormais (DIRKSEN; GRÜNDER; STÖBER, 1993; SPEIRS, 1997).

Para a visualização interna do trato respiratório anterior utilizou-se a técnica de endoscopia (endoscópio flexível da marca Olympus ${ }^{\circledR}$ com fibra óptica de 1,20m 
de comprimento). Os exames endoscópicos foram realizados no dia 0 (préinoculação) e no quinto dia pós-inoculação, com os animais mantidos em estação, com gel anestésico de cloridrato de lidocaína a 2\% (Xylocaina Astra ${ }^{\circledR}$ ) na extremidade da fibra óptica para introdução da mesma na narina, o que possibilitou a inspeção desde a região da cavidade nasal até a porção média da traquéia.

As alterações observadas por esse exame, em especial a hiperplasia linfóide faringeana, foram classificadas pela variação de coloração, localização, tamanho e quantidade dos folículos linfóides no trato respiratório anterior, conforme preconizado por Raker (1982) (Anexo A).

\subsection{EXames Complementares LaboratoriaIS}

\subsubsection{Hemograma}

Diariamente, durante os dez primeiros dias após a inoculação, foram colhidas assepticamente amostras de 3,0ml de sangue pela punção da veia jugular externa, por meio de um sistema a vácuo (Vacutainer ${ }^{\circledR} \mathrm{BD}$, Becton Dickinson) composto por tubos de vidro siliconizado providos de tampa de borracha contendo EDTA K2 como anticoagulante e agulhas descartáveis de $40 \times 9 \mathrm{~mm}$. Após a colheita, as amostras de sangue foram mantidas à temperatura de $4^{\circ} \mathrm{C}$ e processadas com intervalo máximo de 2 horas, conforme descrito por Jain (1986). As lâminas de esfregaço sangüíneo para contagem diferencial de leucócitos foram confeccionadas com sangue in natura, imediatamente após a colheita. A contagem total de hemácias e leucócitos $\left(\right.$ por $\mathrm{mm}^{3}$ ) foi realizada com o auxílio de contador eletrônico da marca Serono Baker $^{\circledR}$ e a contagem diferencial dos leucócitos, pela quantificação de pelo menos 
100 células, foi realizada após coloração das lâminas pelo método de Rosenfeld (1947). A taxa de hemoglobina (g/dl) e o volume globular (\%) foram determinados pelo método de cianometahemoglobina e pela técnica de microhematócrito, respectivamente (BIRGEL, 1982). Os índices hematimétricos absolutos - volume corpuscular médio (VCM), hemoglobina corpuscular média (HCM) e concentração de hemoglobina corpuscular média $(\mathrm{CHCM})$ - foram calculados a partir do número de hemácias, volume globular e teor de hemoglobina (JAIN, 1986). A análise dos resultados baseou-se nos valores de referência descritos para a espécie por Jain (1986) (Anexo B).

\subsubsection{Prova de Sorodiagnóstico para o HVE-1}

Nos períodos pré-inoculação $(-21,-14$ e 0 dias $)$ e pós-inoculação $(+7,+14$, +21 e +28 dias), foram colhidas assepticamente amostras de 10,0ml de sangue, pela punção da veia jugular externa, com tubos de vidro siliconizados providos de tampa de borracha, sem anticoagulante, com sistema a vácuo (Vacutainer ${ }^{\circledR}$ BD, Becton Dickinson) e agulhas descartáveis de $40 \times 9 \mathrm{~mm}$. Os tubos foram mantidos em temperatura ambiente para a coagulação do sangue e retração do coágulo, e posteriormente foram centrifugados (centrífuga Baby Excelsa ${ }^{\circledR}$ 206/l) a uma velocidade de $260 \mathrm{~g}$ por 15 minutos, a fim de separar o soro sangüíneo. Em seguida, as amostras de soro foram aliquotadas em tubos plásticos resistentes ao congelamento e armazenadas à temperatura de $-20^{\circ} \mathrm{C}$, até o momento do processamento laboratorial.

A detecção de anticorpos contra o HVE-1 foi realizada pela microtécnica de soroneutralização, segundo metodologia descrita por Kotait et al. (1989a). 
Os títulos dos soros sangüíneos (expressos em $\log _{10}$ ) foram considerados positivos a partir da menor diluição (maior ou igual a 2) capaz de inibir $100 \%$ do efeito citopático (ECP) viral induzido pelo HVE-1 em cultura de células VERO.

\subsubsection{ISOLAMENTO DO HVE-1}

Para o isolamento viral foram colhidas amostras das secreções presentes na cavidade nasal esquerda dos animais inoculados com o HVE-1 nos dias $0,+01,+02$, $+03,+04,+05,+07$ e +09 após a inoculação. Para tanto, foram utilizadas hastes flexíveis revestidas de algodão estéril nas extremidades (swab). Estas amostras foram mantidas em meio de cultura MEM (meio essencial mínimo) de Eagle com $10 \%$ de soro fetal bovino (SFB), à temperatura de $-70^{\circ} \mathrm{C}$, até o momento da realização das provas de isolamento viral, conforme descrição de Saxegaard (1966). Para isolamento do HVE-1 foram utilizadas células da linhagem VERO cultivadas em monocamadas com meio MEM de Eagle e 10\% SFB. O isolamento viral era considerado positivo quando apresentava ECP característico.

\subsubsection{LAVADO BRONCOALVEOLAR (LBA)}

\subsubsection{COLHEITA DO LBA}

A técnica adotada foi aquela descrita por Fernandes, Mori e Sanches (2000). Os animais foram sedados com cloridrato de xilazina a $10 \%$ (Sedazine ${ }^{\circledR}$, Fort Dodge) na dosagem de $0,44 \mathrm{mg} / \mathrm{kg}$, associado com butorfanol a $1 \%$ (Torbugesic $^{\circledR}$, Fort Dodge) na dosagem de $0,033 \mathrm{mg} / \mathrm{kg}$ por via intravenosa e posicionados em estação, 
com a cabeça e o pescoço estendidos. Um cateter de silicone da marca Bivona ${ }^{\circledR}$, com $10 \mathrm{~mm}$ de diâmetro externo, $2,5 \mathrm{~mm}$ de diâmetro interno e $300 \mathrm{~cm}$ de comprimento, foi introduzido através da narina até a altura dos pequenos brônquios. O volume de $300 \mathrm{ml}$ de solução fisiológica estéril $0,9 \%$ foi introduzido em cinco alíquotas de $60 \mathrm{ml}$ através desse cateter, sendo imediatamente aspirado por meio de sucção leve por seringa. Foram colhidas amostras a cada sete dias, conforme descrito por Kydd, Hannant e Mumford (1996), nos períodos pré-inoculação (-7 dias) e pós-inoculação $(+2,+9,+16,+23$ e +30 dias $)$. As amostras do LBA foram acondicionadas em tubos cônicos de polipropileno de $50 \mathrm{ml}$ e mantidas em gelo até o processamento no laboratório, realizado com intervalo máximo de duas horas após a colheita.

\subsubsection{CITOLOGIA DO LBA}

Para a realização da citologia do LBA, foram confeccionadas lâminas pela citocentrifugação de $200 \mu \mathrm{l}$ das amostras de suspensões celulares, à velocidade de $28 g$ por 6 minutos (citocentrífuga modelo cytospin3 Shadon ${ }^{\circledR}$ ). Essas lâminas foram coradas pelo método de Rosenfeld, e a contagem diferencial foi realizada pela quantificação de pelo menos 300 leucócitos (FERNANDES; MORI; SANCHES, 2000). A análise dos resultados baseou-se nos valores de referência descritos para a espécie por Fernandes, Mori e Sanches (2000) (Anexo C). 


\subsection{EXTRAÇÃO DO DNA VIRAL}

\subsubsection{Colmeita de SANGUe PARA EXTRAÇÃo do DNA VIRAL}

Diariamente, nos dez primeiros dias pós-inoculação, e semanalmente, nos dias $+16,+23$ e +30 pós-inoculação, foram colhidas amostras de 20,0ml de sangue, por punção da veia jugular externa, com agulhas descartáveis de $40 \times 12 \mathrm{~mm}$, em tubos cônicos de polipropileno de 50ml contendo 40mg de EDTA K2 (Merck) como anticoagulante. As amostras de sangue foram conservadas à temperatura de $4^{\circ} \mathrm{C}$, e as hemácias foram lisadas em intervalo máximo de 24 horas após a colheita.

Para a lise das hemácias, as amostras de sangue foram adicionadas de $20 \mathrm{ml}$ de uma solução tampão $\mathrm{A}\left(144 \mathrm{mM} \mathrm{NH}_{4} \mathrm{Cl} ; 1 \mathrm{mM} \quad \mathrm{NH}_{4} \mathrm{HCO}_{3}\right)$, agitando-se vigorosamente os tubos e incubando-os em gelo por 10 minutos. Posteriormente todas as amostras foram centrifugadas a $3500 \mathrm{~g}$, por 10 minutos, em temperatura de $4^{\circ} \mathrm{C}$ (centrífuga refrigerada Sorvall ${ }^{\circledR}$ modelo RT7); em seguida, o sobrenadante foi desprezado. Os sedimentos celulares foram ressuspensos em $40 \mathrm{ml}$ de tampão A, agitando-se vigorosamente os tubos e incubando-os em gelo por 10 minutos. Esse procedimento foi repetido até que os sedimentos ficassem bem claros e livres de resíduos de hemácias. A seguir, as amostras foram armazenadas em microtubos de polipropileno de $1,5 \mathrm{ml}$ (Axygen) e congeladas a $-70^{\circ} \mathrm{C}$, para posterior extração do DNA. 


\subsubsection{EXTRAÇÃO DO DNA VIRAL DO SANGUE}

A extração do DNA genômico, a partir do sangue total, foi realizada com a utilização de uma solução de fenol e isotiocianato de guanidina (TRIzol ${ }^{\circledR}$, Invitrogen Life Technologies) associado com clorofórmio (Merck), conforme técnica descrita por Chomczynski (1993).

Após descongelamento, o sedimento leucocitário foi ressuspenso e homogeneizado com $1,0 \mathrm{ml}$ de $\mathrm{TRIzol}^{\circledR}$. Essa mistura foi incubada por 5 minutos à temperatura ambiente $\left(15\right.$ a $\left.30^{\circ} \mathrm{C}\right)$, e posteriormente foram adicionados $200 \mu \mathrm{l}$ de clorofórmio (Merck). Após a agitação vigorosa dos tubos por 15 segundos, a mistura foi novamente incubada por 2-3 minutos à temperatura ambiente. Em seguida, ela foi centrifugada a $12.000 \mathrm{~g}$ por 15 minutos a $4^{\circ} \mathrm{C}$ (centrífuga Eppendorf ${ }^{\circledR}$ modelo $5417 \mathrm{R}$ ). Após a centrifugação, a mistura foi separada em três fases distintas: na parte inferior do tubo uma fase orgânica (vermelha), uma interfase branca e, na parte superior, uma fase aquosa (incolor) contendo proteínas, DNA e RNA, respectivamente.

A fase aquosa foi desprezada e as fases remanescentes ressuspensas em 0,3ml de etanol $100 \%$. Após a homogeneização por simples inversão, essa mistura foi incubada por 2-3 minutos à temperatura ambiente. Em seguida, ela foi centrifugada a $3.500 \mathrm{~g}$ por 5 minutos a $4^{\circ} \mathrm{C}$ (centrífuga Eppendorf ${ }^{\circledR}$ modelo $5417 \mathrm{R}$ ).

O sobrenadante fenol-etanol foi desprezado e o DNA precipitado foi ressuspenso em $1,0 \mathrm{ml}$ de solução de citrato de sódio $0,1 \mathrm{M}$ em etanol a $10 \%$. Em seguida, a lavagem do DNA foi efetuada por meio da homogeneização periódica por 30 minutos à temperatura ambiente e, posteriormente, esse material foi submetido à centrifugação a $3.500 \mathrm{~g}$ por 5 minutos a $4^{\circ} \mathrm{C}$ (centrífuga Eppendorf ${ }^{\circledR}$ modelo $5417 \mathrm{R}$ ). Este procedimento foi repetido duas vezes. 
Após as lavagens, o DNA precipitado foi ressuspenso em $1,5 \mathrm{ml}$ de etanol $75 \%$ e incubado por 10-20 minutos à temperatura ambiente. Em seguida, o material foi centrifugado a $3.500 \mathrm{~g}$ por 5 minutos a $4^{\circ} \mathrm{C}$ (centrífuga Eppendorf ${ }^{\circledR}$ modelo 5417R).

O DNA precipitado foi ressuspenso em TE (10mM Tris-HCl, 1mM EDTA pH 8,0) - conforme a quantidade obtida -, e incubado em banho-maria a $65^{\circ} \mathrm{C}$, por 10 minutos. Posteriormente, o DNA foi quantificado em espectrofotômetro com absorbância de $260 \mathrm{~nm}$ para ácidos nucléicos e de $280 \mathrm{~nm}$ para proteínas (modelo Biophotometer Eppendorf $^{\circledR}$ ). Avaliou-se também o grau de pureza do DNA, calculado pela razão da absorbância de $260 \mathrm{~nm}$ e $280 \mathrm{~nm}$. Os DNA puros, livres de proteína e de outros contaminantes que possam inibir a PCR, possuem razão A260/A280 entre 1,70 e $1,90$.

\subsubsection{EXTRAÇÃO DO DNA VIRAL DO LBA}

As células presentes no LBA foram processadas pela centrifugação à velocidade de $450 \mathrm{~g}$ durante 20 minutos, em temperatura de $4^{\circ} \mathrm{C}$ (centrífuga refrigerada Sorvall ${ }^{\circledast}$ modelo RT7) e congeladas a $-70^{\circ} \mathrm{C}$, para posterior extração do DNA. A extração de DNA foi realizada conforme descrito para as amostras de sangue, iniciando-se o procedimento pela adição do TRIzol ${ }^{\circledR}$.

\subsection{Deteç̧ão do HVE-1 Pela Reação em Cadeia pela Polimerase (PCR)}

Para a detecção do HVE-1 nas amostras de sangue e de LBA foi utilizada a PCR, conforme propõem Carvalho et al. (2000a) e Kirisawa et al. (1993). 
Os oligonucleotídeos iniciadores (primers) (Invitrogen Life Techonlogies) para diagnóstico foram selecionados para a região do gene que codifica a glicoproteína B (gB) do HVE-1, sendo os da primeira PCR: FC2 (5'-CTTGTGAGATCTAACCGCAC3') senso e RC (5'-GGGTATAGAGCTTTCATGGG-3') anti-senso; e os da segunda semi-nested PCR: FC2 (5'-CTTGTGAGATCTAACCGCAC-3') senso e R1 (5'GCGTTATAGCTATCACGTCC-3') anti-senso, para amplificar fragmentos de $1.181 \mathrm{e}$ de 460 pares de base (pb), respectivamente (Fig. 3) (KIRISAWA et al., 1993).

\begin{tabular}{|c|c|c|c|c|c|c|}
\hline & & & FC2 & $\rightarrow$ & & \\
\hline 2881 & GAACTCGCCA & GGCTGTACCT & GAACGAGCTT & GTGAGATCTA & ACCGCACCTA & CGACCTAAAA \\
\hline 941 & AАTCTATTGA & ACCCCAATGC & AAACAATAAC & AATAACACCA & CGCGAAGACG & CAGGTCTCTC \\
\hline 3001 & CTGTCAGTAC & CAGAACCTCA & GCCAACCCAA & GATGGTGTGC & ATAGAGAACA & ААTTCTACAT \\
\hline 3061 & CGCTTGCACA & AACGAGCAGT & GGAGGCAACG & GCAGGTACCG & АTTСTTCCAA & CGTCACCGCC \\
\hline 3121 & AAACAGCTGG & AGCTCATCAA & AACCACGTCG & TCTATCGAGT & TTGCCATGCT & ACAGTTTGCA \\
\hline 3181 & TACGATCACA & TCCAATCCCA & CGTCAATGAA & ATGCTAAGTA & GAATAGCAAC & TGCGTGGTGT \\
\hline 3241 & АСССТССАAА & ACAAAGAGCG & GACССТATGG & AACGAAATGG & TGAAGATTAA & CCCGAGCGCC \\
\hline 3301 & $\begin{array}{c}\text { ATAGTCTCCG } \\
\leftarrow \mathbf{R} \mathbf{1}\end{array}$ & CAACCCTTGA & CGAGCGAGTT & GCAGCGAGGG & TCCTGGGGGA & CGT \\
\hline 361 & ATAACGCACT & GCGCCAAAAT & AGAGGGCAAC & GTGTACTTGC & ААААСТССАТ & GCGCTCGATG \\
\hline 63421 & ACAGTAACA & CGTGCTACTC & $\mathrm{CCGCCCCCCC}$ & GTAACATTTA & CAATTACTAA & GAATGCAAAC \\
\hline 218 & AGGGT & $A G G$ & GGA & GAGGAGAACG & AGATTTTCAC & GGAGCGCAAG \\
\hline 3541 & $\mathrm{CTGP}$ & CGT & CAAT & CGCTACTTTA & AGTTTGGCAA & CGTT \\
\hline 1 & TACTACGAGA & ACTACACGTT & CGTCCGCAAA & GTGCCCCCCA & CGGAAATCGA & GGTTATCAGC \\
\hline 3661 & ACGTACGTTG & AACTAAACTT & GACCCTTTTG & GAAGACCGCG & AGTTTCTGCC & CCTGGAGGTG \\
\hline 3721 & TACACGCGGG & CTGAGCTGGA & GGACACCGGC & CTGCTAGACT & ACAGCGAAAT & ACAGCGCCGC \\
\hline 63781 & $\mathrm{AC}$ & $A G$ & ACGAC & GCG & $\mathrm{AACGT}$ & GGP \\
\hline 63841 & A & & TTT & TTC & $G T$ & GGC \\
\hline 63901 & GTGGGAACGC & TCGTTCTCGG & $\mathrm{CGCCG}$ & GCTGTTGTTT & CAACCGTATC & TGG \\
\hline 63961 & TCGTTTTTAA & ACAACCCATT & TGGGGGGCTA & GCCATCGGCC & TGCTGGTAAT & CGCCGG \\
\hline & $\begin{array}{c}\text { GTAGCTGCGT } \\
\leftarrow \mathbf{R C}\end{array}$ & TTTTTGCTTA & CAGATATGTA & ATGCAGATCC & GCAGTAACCC & CATGAAAGCT \\
\hline & ATACCCCA & ACAACAAA & $A A A$ & AACAAAGCCA & AAACTTCCTA & CGGCCA \\
\hline
\end{tabular}

Figura 3 - Seqüência de nucleotídeos (sentido $5^{\prime} \rightarrow 3^{\prime}$ ) representativa da região do gene que codifica a glicoproteína $B(\mathrm{gB})$ do herpesvírus equino tipo 1 (HVE-1) determinada pelos oligonucleotídeos iniciadores (primers) FC2 (senso), RC (anti-senso) e R1 (anti-senso)

Fonte dos dados brutos: NCBI 
Também foram selecionados oligonucleotídeos iniciadores para a região do gene que codifica a timidina quinase (tk) do HVE-1, sendo os da primeira PCR: tkF1 (5'-CGGGACCGCAGCTGGAAAT-3') senso e tkR2 (5'-CTGGCGAGAACGCTACCC3') anti-senso; e os da segunda semi-nested PCR: tkF3 (5'CCTTGGTTCCTTTGGCGACGCAC-3') senso e tkR2 (5'CTGGCGAGAACGCTACCC-3') anti-senso, para amplificar fragmentos de 333 e de 226pb, respectivamente (Fig. 4) (CARVALHO et al., 2000a).

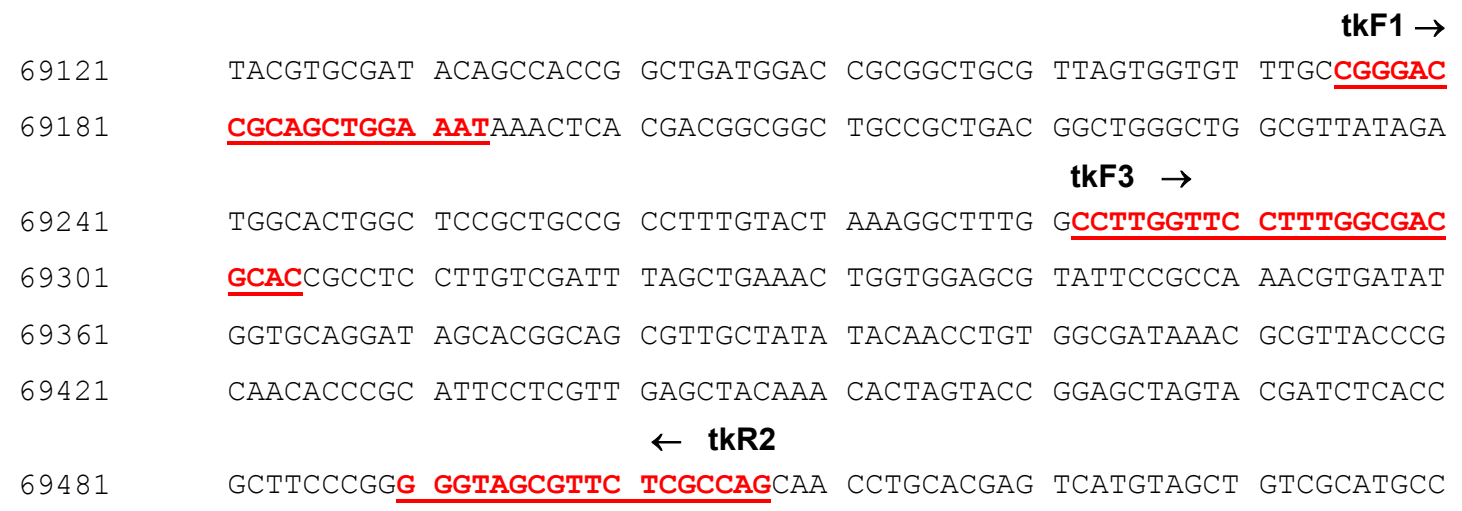

Figura 4 - Seqüência de nucleotídeos (sentido 5' $\rightarrow$ 3') representativa da região do gene que codifica a timidina quinase (tk) do herpesvírus eqüino tipo 1 (HVE-1) determinada pelos oligonucleotídeos iniciadores (primers) tkF1 (senso), tkR2 (anti-senso) e tkF3 (senso)

Fonte dos dados brutos: NCBI

O Quadro 5 demonstra a localização dos oligonucleotídeos iniciadores selecionados para a PCR no genoma do HVE-1. 
Quadro 5 - Oligonucleotídeos iniciadores (primers) selecionados para a reação em cadeia pela polimerase (PCR) para a identificação do herpesvírus eqüino tipo 1 (HVE-1)

\begin{tabular}{lccc}
\hline \multicolumn{1}{c}{ Primers } & Seqüência de nucleotídeos & $\begin{array}{c}\text { Posição no } \\
\text { Genoma Viral } \\
\left({ }^{*}\right)\end{array}$ & Seqüência Alvo \\
\hline FC2 (senso) & 5'-CTTGTGAGATCTAACCGCAC-3' & 62908 & gB \\
RC (anti-senso) & 5'-GGGTATAGAGCTTTCATGGG-3' & 63367 & $\mathrm{gB}$ \\
R1 (anti-senso) & 5'-GCGTTATAGCTATCACGTCC-3' & 64088 & $\mathrm{gB}$ \\
tkF1 (senso) & 5'-CGGGACCGCAGCTGGAAAT-3' & 69175 & tk \\
tkR2 (anti-senso) & 5'-CTGGCGAGAACGCTACCC-3' & 69507 & tk \\
tkF3 (senso) & 5'-CCTTGGTTCCTTTGGCGACGCAC-3' & 69282 & tk \\
\hline
\end{tabular}

gB: glicoproteína B; tk: timidina quinase.

Fonte dos dados brutos: ${ }^{a}$ Kirisawa et al. (1993); ${ }^{b}$ Carvalho et al. (2000a); ( ${ }^{*}$ NCBI

Na primeira etapa da $\mathrm{PCR}$, para ambas as regiões (gB e tk), a reação foi realizada em um volume final de $50 \mu \mathrm{l}$, em microtubos de polipropileno de $200 \mu \mathrm{l}$ (Axygen) contendo $3 \mu \mathrm{l}$ da amostra $(0,5-1,0 \mu \mathrm{g}$ de DNA), $200 \mu \mathrm{M}$ de cada

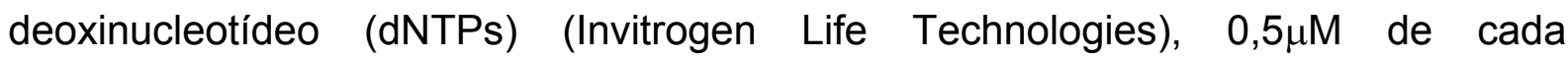
oligonucleotídeo iniciador, $5 \mu \mathrm{l}$ de tampão de reação $1 \times(20 \mathrm{mM}$ de Tris- $\mathrm{HCl}$ pH 8,4 e $50 \mathrm{mM}$ de $\mathrm{KCl}$ ), $1,5 \mathrm{mM}$ de $\mathrm{MgCl}_{2}$ e $0,25 \mu \mathrm{l}(2,5 \mathrm{U})$ de Taq DNA polimerase (Invitrogen Life Technologies).

A amplificação do DNA foi realizada em um termociclador (PTC-200 MJ Research $^{\circledR}$.

Segundo o método descrito por Kirisawa et al. (1993) e modificado por Wilcox e Raidal (2000) para a região do gene que codifica a glicoproteína B (gB) do HVE-1, a amplificação do DNA respeitou o seguinte ciclo: $94^{\circ} \mathrm{C}$ por 5 minutos para a desnaturação inicial, 35 ciclos de $94^{\circ} \mathrm{C}$ por 1 minuto para a desnaturação, $60^{\circ} \mathrm{C}$ por 
1 minuto para a hibridização ("anelamento") dos oligonucleotídeos iniciadores e $72^{\circ} \mathrm{C}$ por 1 minuto para a extensão dos oligonucleotídeos iniciadores. A extensão final foi realizada à temperatura de $72^{\circ} \mathrm{C}$, por 7 minutos. Após a primeira etapa de amplificação, o volume de $1 \mu \mathrm{l}$ de cada amostra (produto da primeira PCR) foi transferido para microtubos novos contendo os reagentes recém adicionados e os dois oligonucleotídeos iniciadores internos. As condições da segunda etapa de PCR (semi-nested) foram idênticas àquelas da primeira etapa (Quadro 6).

Quadro 6 - Condições de temperatura e de tempo selecionadas para o ciclo da reação em cadeia pela polimerase (PCR), utilizando oligonucleotídeos iniciadores (primers) para a região do gene que codifica a glicoproteína $\mathrm{B}(\mathrm{gB})$ do herpesvírus eqüino tipo 1 (HVE-1)

\begin{tabular}{|c|c|c|}
\hline Etapas do programa & & $\begin{array}{c}\text { PCR } \\
\text { (Temperatura/tempo) }\end{array}$ \\
\hline Desnaturação inicial & & $94^{\circ} \mathrm{C}$ (5 minutos) \\
\hline Desnaturação & & $94^{\circ} \mathrm{C}$ (1 minuto) \\
\hline Hibridização ("anelamento") & (35 ciclos) & $60^{\circ} \mathrm{C}$ (1 minuto) \\
\hline Extensão & & $72^{\circ} \mathrm{C}$ (1 minuto) \\
\hline Extensão Final & & $72^{\circ} \mathrm{C}$ (7 minuto $)$ \\
\hline
\end{tabular}

Fonte dos dados brutos: Wilcox e Raidal (2000)

Segundo o método proposto por Carvalho et al. (2000a) para a região do gene que codifica a timidina quinase (tk) do HVE-1, a amplificação do DNA respeitou o seguinte ciclo: $95^{\circ} \mathrm{C}$ por 5 minutos para a desnaturação inicial, 5 ciclos de $94^{\circ} \mathrm{C}$ por 1 minuto para a desnaturação, $56^{\circ} \mathrm{C}$ por 1 minuto para a hibridização dos oligonucleotídeos iniciadores e $72^{\circ} \mathrm{C}$ por 1 minuto para a extensão dos 
oligonucleotídeos iniciadores, seguido de 35 ciclos de $92^{\circ} \mathrm{C}$ por 1 minuto, $56^{\circ} \mathrm{C}$ por 1 minuto e $72^{\circ} \mathrm{C}$ por 1 minuto. A extensão final foi realizada à temperatura de $72^{\circ} \mathrm{C}$, por 1 minuto. Após a primeira etapa de amplificação, o volume de $1 \mu$ le cada amostra (produto da primeira PCR) foi transferido para microtubos novos contendo os reagentes recém adicionados e os dois oligonucleotídeos iniciadores internos. As condições da segunda etapa de PCR foram idênticas àquelas da primeira etapa, exceto pela temperatura de desnaturação - que foi de $90^{\circ} \mathrm{C}$-, e pela temperatura de hibridização dos oligonucleotídeos iniciadores - que foi de $58^{\circ} \mathrm{C}$ nos 35 ciclos após os 5 ciclos iniciais (Quadro 7).

Quadro 7 - Condições de temperatura e de tempo selecionadas para o ciclo da reação em cadeia pela polimerase (PCR), utilizando oligonucleotídeos iniciadores (primers) para a região do gene que codifica a timidina quinase (tk) do herpesvírus eqüino tipo 1 (HVE-1)

\begin{tabular}{|c|c|c|c|}
\hline Etapas do programa & & $\begin{array}{c}\left.\text { PCR ( } 1^{\text {a }} \text { etapa }\right) \\
\text { (Temperatura/tempo) }\end{array}$ & $\begin{array}{c}\text { PCR }\left(2^{\mathrm{a}} \text { etapa }\right) \\
\text { (Temperatura/tempo) }\end{array}$ \\
\hline Desnaturação inicial & & $95^{\circ} \mathrm{C}$ (5 minutos) & $95^{\circ} \mathrm{C}$ (5 minutos) \\
\hline Desnaturação & & $94^{\circ} \mathrm{C}$ (1 minuto) & $94^{\circ} \mathrm{C}$ (1 minuto) \\
\hline Hibridização & (5 ciclos) & $56^{\circ} \mathrm{C}$ (1 minuto) & $56^{\circ} \mathrm{C}$ (1 minuto) \\
\hline Extensão & & $72^{\circ} \mathrm{C}$ (1 minuto) & $72^{\circ} \mathrm{C}$ (1 minuto) \\
\hline Desnaturação & & $92^{\circ} \mathrm{C}$ (1 minuto) & $90^{\circ} \mathrm{C}$ (1 minuto) \\
\hline Hibridização & (35 ciclos) & $56^{\circ} \mathrm{C}$ (1 minuto) & $58^{\circ} \mathrm{C}$ (1 minuto) \\
\hline Extensão & & $72^{\circ} \mathrm{C}$ (1 minuto $)$ & $72^{\circ} \mathrm{C}$ (1 minuto) \\
\hline Extensão Final & & $72^{\circ} \mathrm{C}$ (1 minuto) & $72^{\circ} \mathrm{C}$ (1 minuto) \\
\hline
\end{tabular}

Fonte dos dados brutos: Carvalho et al. (2000a) 
Em todas as reações foram utilizados controles negativos contendo a mesma mistura de reagentes, nos quais o DNA foi substituído por água ultrapura MilliQ ${ }^{\circledR}$.

As amostras de DNA viral utilizadas como controles positivos na PCR foram derivadas das estirpes de HVE-1 como descritas a seguir: (1) amostra padrão A4/72 (Instituto Biológico de São Paulo, São Paulo - SP); (2) vacina de vírus inativado contra aborto eqüino (Equibort ${ }^{\circledR}$, Biovet); (3) vacina de vírus inativado contra rinopneumonite eqüina derivada da estirpe viral Army 183 (Pneumoabort ${ }^{\circledR} \mathrm{K}+1 \mathrm{~b}$, Fort Dodge).

Um volume de $10 \mu \mathrm{l}(7 \mu \mathrm{l}$ dos produtos de amplificação da segunda etapa de PCR adicionados de $3 \mu l$ de azul de bromofenol) foi submetido inicialmente à eletroforese em gel de agarose a 1,5\% em tampão TAE (40mM Tris-acetato, $2 \mathrm{mM}$ EDTA pH 8,5) $1 \times$ concentrado. A corrida eletroforética foi realizada a $100 \mathrm{~V}$ por 70 minutos, em cuba horizontal de $12 \times 14 \mathrm{~cm}$ (Loccus Biotecnologia). As bandas foram visualizadas em transluminador de luz ultravioleta, após corar o gel em uma solução de brometo de etídio (Invitrogen Life Technologies) na concentração de $0,5 \mu \mathrm{g} / \mathrm{ml}$ (Fig. 5), conforme descrito por Sambrook, Fritsch e Maniatis (1989). 

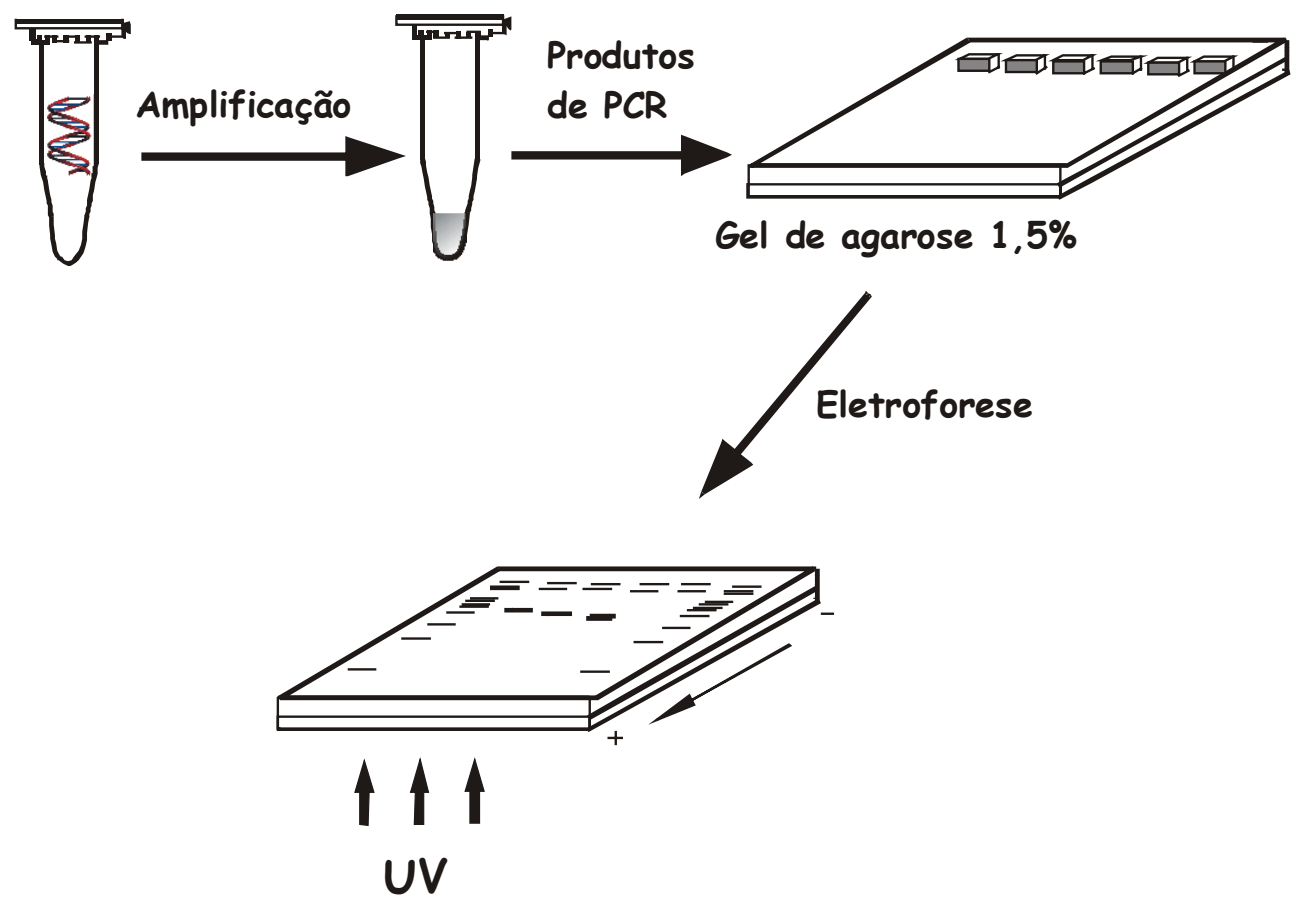

Figura 5 - Representação esquemática das etapas da detecção do herpesvírus eqüino tipo 1 (HVE-1), pela reação em cadeia pela polimerase (PCR)

As amostras que apresentaram resultados negativos ou duvidosos "fracamente" positivos - foram submetidas à eletroforese em gel de poliacrilamida a $8 \%$ em tampão TAE $1 \times$ concentrado. A corrida eletroforética foi realizada a $200 \mathrm{~V}$ por 4 horas, em cuba vertical (Invitrogen Life Technologies). As bandas foram visualizadas após corar o gel em solução de nitrato de prata (Merck), como descrito por Carvalho, Passos e Martins (2000). O gel de poliacrilamida inicialmente foi submerso em $100 \mathrm{ml}$ de solução fixadora $(10 \%$ de etanol e $0,5 \%$ de ácido acético glacial) por 6 minutos; posteriormente essa solução foi desprezada e o gel foi corado em $100 \mathrm{ml}$ de solução de nitrato de prata $0,1 \%$, seguido de lavagem do excedente com água ultra-pura $\mathrm{Milli}^{\circledR}$. A seguir, o gel foi revelado com $100 \mathrm{ml}$ de $\mathrm{NaOH}$ a $3 \%$ associado com $1 \%$ de formaldeídeo.

O tamanho das bandas de DNA foi comparado a um padrão de peso 
molecular conhecido, apresentando escalas de 100pb (100pp DNA Ladder, Invitrogen Life Technologies).

Foram utilizados no mínimo três ambientes separados para evitar contaminação dos produtos pré-amplificados (carry-over): (1) na preparação das amostras (área de extração de DNA); (2) na mistura dos reagentes para a PCR (área pré-PCR); e (3) na análise dos produtos da PCR (área pós-PCR). Além disso, cuidados adicionais foram tomados para evitar essa contaminação, como: uso de ponteiras com filtro resistente a aerossóis, troca periódica de luvas a cada tipo de procedimento e uso de fluxo laminar na manipulação dos produtos amplificados para a segunda etapa de PCR (CARVALHO; PASSOS; MARTINS, 2000).

\subsection{INFECÇÃo EXPERIMENTAL PELO HVE-1 EM CAMUNDONGOS}

Para verificar se a estirpe A4/72 do HVE-1 proveniente do Instituto Biológico de São Paulo mantinha a sua virulência após sucessivas passagens em cultivo de células não-eqüinas (VERO), utilizou-se um modelo de infecção experimental em camundongos, descrito a seguir:

\subsubsection{Camundongos}

Foram utilizados doze camundongos (Mus musculus), BALB/c, fêmeas, com quatro semanas de idade, livre de patógenos específicos (SPF), provenientes do Biotério de Camundongos Isogênicos do Departamento de Imunologia do Instituto de Ciências Biomédicas da Universidade de São Paulo (ICB/USP). 
Os animais foram divididos em lotes de quatro indivíduos e mantidos em gaiolas de polipropileno com filtro medindo $365 \times 270 \times 140 \mathrm{~mm}$. A cama foi a maravalha de pinus autoclavada, trocada semanalmente. Todos os animais foram mantidos em salas com sistema de ar condicionado central e controle de temperatura e umidade relativa do ar, $22 \pm 2{ }^{\circ} \mathrm{C}$ e $55 \pm 10 \%$, respectivamente. A iluminação foi artificial, controlada por timer, com ciclo de 12 horas de claro e 12 horas de escuro. Água filtrada e autoclavada e ração comercial autoclavada foram oferecidas ad libitum durante todo o experimento. As condições de alojamento e de manejo dos animais e os procedimentos experimentais estão de acordo com a Comissão de Bioética da Faculdade de Medicina Veterinária e Zootecnia da Universidade de São Paulo e seguem as normas internacionais, em especial àquelas do National Research Council (1996).

Os camundongos foram distribuídos em dois grupos: oito animais experimentais e quatro animais controle.

\subsubsection{INÓcULO VIRAL}

Foi utilizado o HVE-1 derivado da amostra padrão de vírus A4/72 adaptado em cultura de células VERO, proveniente do Instituto Biológico de São Paulo (São Paulo-SP). O inóculo viral de desafio foi de $10^{6,6}$ DICT $_{50} / \mathrm{ml}$ do HVE-1.

\subsubsection{INOCULAÇÃo INTRANASAL DO HVE-1}

Cerca de $40 \mu \mathrm{l}$ de meio MEM de Eagle contendo a suspensão de vírus foram inoculados nas narinas de oito animais do grupo experimental, até a sua aspiração 
completa (AWAN; CHONG; FIELD, 1990). Nos quatro animais do grupo controle, a inoculação foi realizada pela aspiração do mesmo volume de solução fosfatada salina tamponada (PBS) estéril.

\subsubsection{EXAME Físıco}

Os camundongos dos grupos controle e experimental foram examinados diariamente e pesados individualmente durante o período de nove dias pósinoculação com HVE-1 (AWAN; CHONG; FIELD, 1990).

\subsubsection{EXAmes AnÁtomo e Histopatológico}

Os camundongos foram submetidos à eutanásia de acordo com o aparecimento das manifestações clínicas. Para tanto, foi utilizado tiopental sódico na dosagem de $150 \mathrm{mg} / \mathrm{kg}$. Os animais foram necropsiados, observando-se possíveis alterações macroscópicas. Os órgãos internos (cérebro, pulmão, coração, fígado, rim e baço) foram colhidos e os fragmentos fixados em formol a $10 \%$. Foram confeccionadas lâminas coradas por hematoxilina e eosina (HE).

\subsubsection{ISOLAMENTO DO HVE-1}

Fragmentos de pulmão foram mantidos em meio MEM de Eagle com $10 \%$ de soro fetal bovino (SFB), à temperatura de $-70^{\circ} \mathrm{C}$, até o momento da realização das provas de isolamento viral, conforme descrição de Saxegaard (1966). 


\subsection{Análise dos Resultados}

A análise dos dados foi realizada com o auxílio do programa estatístico GraphPad InStat ${ }^{\circledR}$ versão 3.01, 32 bit para Windows 95/NT. Cada parâmetro foi testado para normalidade aplicando o método de Kolmogorov e Smirnov. Os resultados obtidos em cada experimento foram analisados pela comparação entre as médias e os desvios padrões representativos dos diferentes dias pós-inoculação. 0 teste estatístico aplicado para avaliar os dados obtidos foi a análise de variância (ANOVA). Para a comparação do peso corpóreo dos camundongos utilizou-se o teste $\mathrm{t}$ de Student. Estabeleceu-se o valor de 0,05 como nível de rejeição da hipótese de nulidade $(p)$. 


\subsection{EXames Físico e Endoscópico}

Nos primeiros dez dias após a inoculação com o HVE-1, o exame físico dos animais revelou manifestações clínicas de doença respiratória a seguir descritas:

No exame das mucosas aparentes, óculo-palpebrais e nasal, observou-se a presença de congestão (cor avermelhada) e de secreção (lacrimejamento e corrimento nasal). Nos primeiros três dias pós-inoculação, essa secreção era serosa bilateral, em pequena quantidade, intermitente, transparente e incolor, de consistência líquida e inodora. Após esse período, a secreção tornou-se seromucosa, de coloração esbranquiçada, de consistência viscosa e ressecada ao redor das narinas, desaparecendo entre o nono e o décimo dia pós-inoculação.

Os linfonodos mandibulares apresentaram discreto aumento de tamanho e constatou-se sensibilidade dolorosa à palpação, embora sem alterações de consistência, mobilidade e temperatura.

As freqüências respiratória e cardíaca, em todos os animais, permaneceram dentro dos limites descritos para espécie (SPEIRS, 1997) (Anexo D). Também não ocorreram alterações comportamentais, como depressão ou diminuição do apetite.

A temperatura corpórea de todos os animais oscilou dentro dos limites estabelecidos para a espécie por Speirs (1997) (Anexo D), notando-se, em geral, aferições mais baixas pela manhã e mais altas à tarde (Tab. 1; Graf. 1 e 2).

No exame do sistema respiratório, os animais não apresentaram dispnéia, espirros, tosse ou estridores durante todo o período experimental. Na palpação da traquéia e da laringe não foram detectados aumento da sensibilidade local, do reflexo da tosse ou mesmo presença de frêmitos. Ao se examinar o tórax, não foram observadas presença de frêmito pela palpação ou alterações de sons pela 
percussão. A auscultação da traquéia e do tórax revelou ausência de ruídos respiratórios anormais.

Tabela 1 - Variação da temperatura corpórea $\left({ }^{\circ} \mathrm{C}\right)$ de cavalos dos grupos experimentais I e II inoculados com o herpesvírus eqüino tipo 1 (HVE-1). Os resultados foram expressos em média \pm desvio padrão $(n=5)$. São Paulo, 2004

\begin{tabular}{|c|c|c|c|c|}
\hline \multicolumn{5}{|c|}{ Temperatura Corpórea $\left({ }^{\circ} \mathrm{C}\right)$} \\
\hline \multirow{2}{*}{$\begin{array}{l}\text { Dias pós- } \\
\text { inoculação }\end{array}$} & \multicolumn{2}{|c|}{ Grupo I } & \multicolumn{2}{|c|}{ Grupo II } \\
\hline & Manhã & Tarde & Manhã & Tarde \\
\hline 0 & $36,8 \pm 0,4$ & $37,6 \pm 0,5$ & $36,5 \pm 0,4$ & $37,1 \pm 0,3$ \\
\hline 01 & $37,2 \pm 0,3$ & $37,6 \pm 0,3$ & $36,8 \pm 0,1$ & $37,0 \pm 0,4$ \\
\hline 02 & $37,3 \pm 0,2$ & $37,5 \pm 0,3$ & $36,5 \pm 0,4$ & $36,9 \pm 0,2$ \\
\hline 03 & $37,1 \pm 0,3$ & $37,6 \pm 0,3$ & $36,2 \pm 0,3$ & $37,5 \pm 0,2$ \\
\hline 04 & $37,2 \pm 0,3$ & $37,7 \pm 0,2$ & $36,4 \pm 0,3$ & $37,1 \pm 0,4$ \\
\hline 05 & $37,3 \pm 0,3$ & $37,8 \pm 0,3$ & $36,7 \pm 0,8$ & $36,7 \pm 0,2$ \\
\hline 06 & $36,9 \pm 0,3$ & $37,6 \pm 0,3$ & $36,6 \pm 0,1$ & $37,0 \pm 0,3$ \\
\hline 07 & $36,9 \pm 0,3$ & $37,6 \pm 0,2$ & $36,4 \pm 0,3$ & $37,0 \pm 0,2$ \\
\hline 08 & $37,0 \pm 0,3$ & $37,7 \pm 0,4$ & $36,5 \pm 0,2$ & $37,1 \pm 0,2$ \\
\hline 09 & $36,7 \pm 0,3$ & $37,7 \pm 0,1$ & $36,4 \pm 0,4$ & $37,0 \pm 0,2$ \\
\hline 10 & $37,2 \pm 0,1$ & $37,9 \pm 0,3$ & $36,5 \pm 0,2$ & $37,3 \pm 0,2$ \\
\hline
\end{tabular}




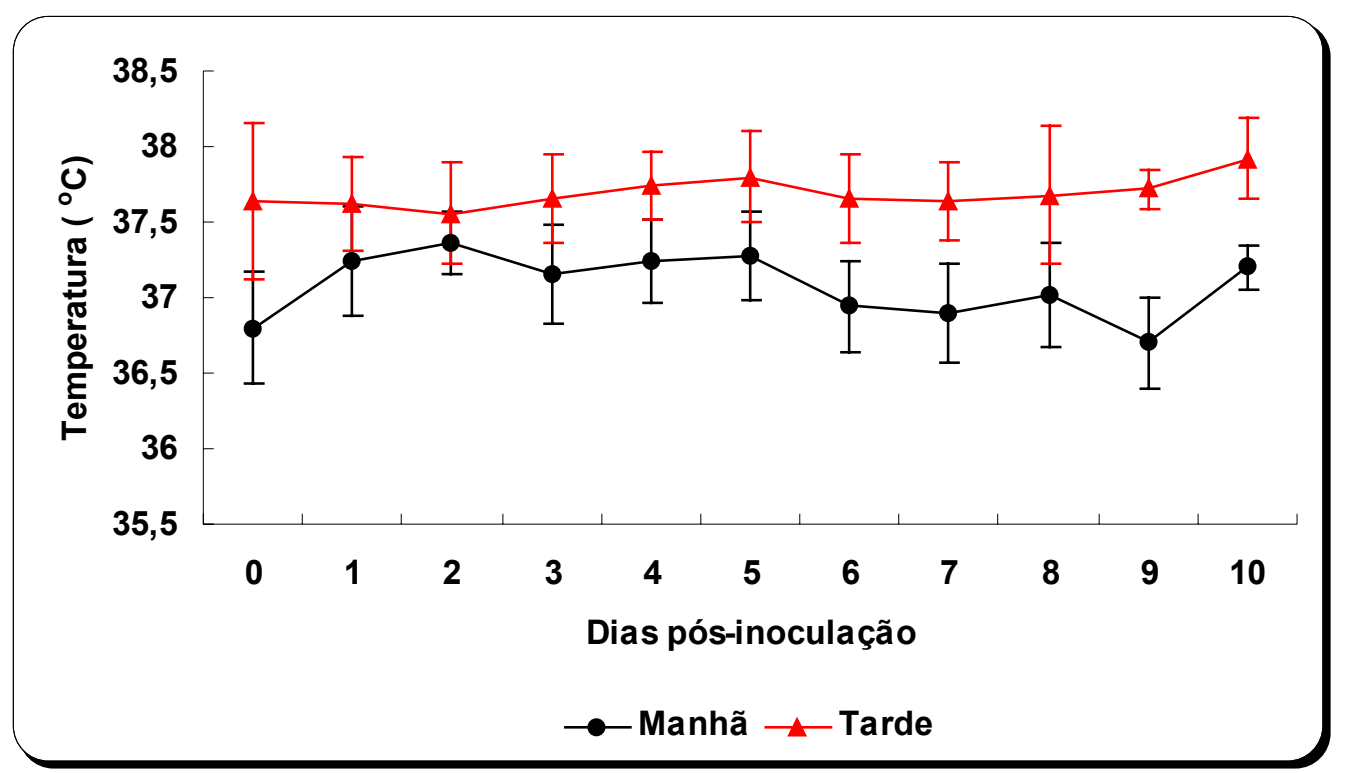

Gráfico 1 - Representação da variação da temperatura corpórea $\left({ }^{\circ} \mathrm{C}\right)$ de cavalos do grupo experimental I inoculados com o herpesvírus eqüino tipo 1 (HVE-1). Os resultados foram expressos em média \pm desvio padrão $(n=5)$. São Paulo, 2004

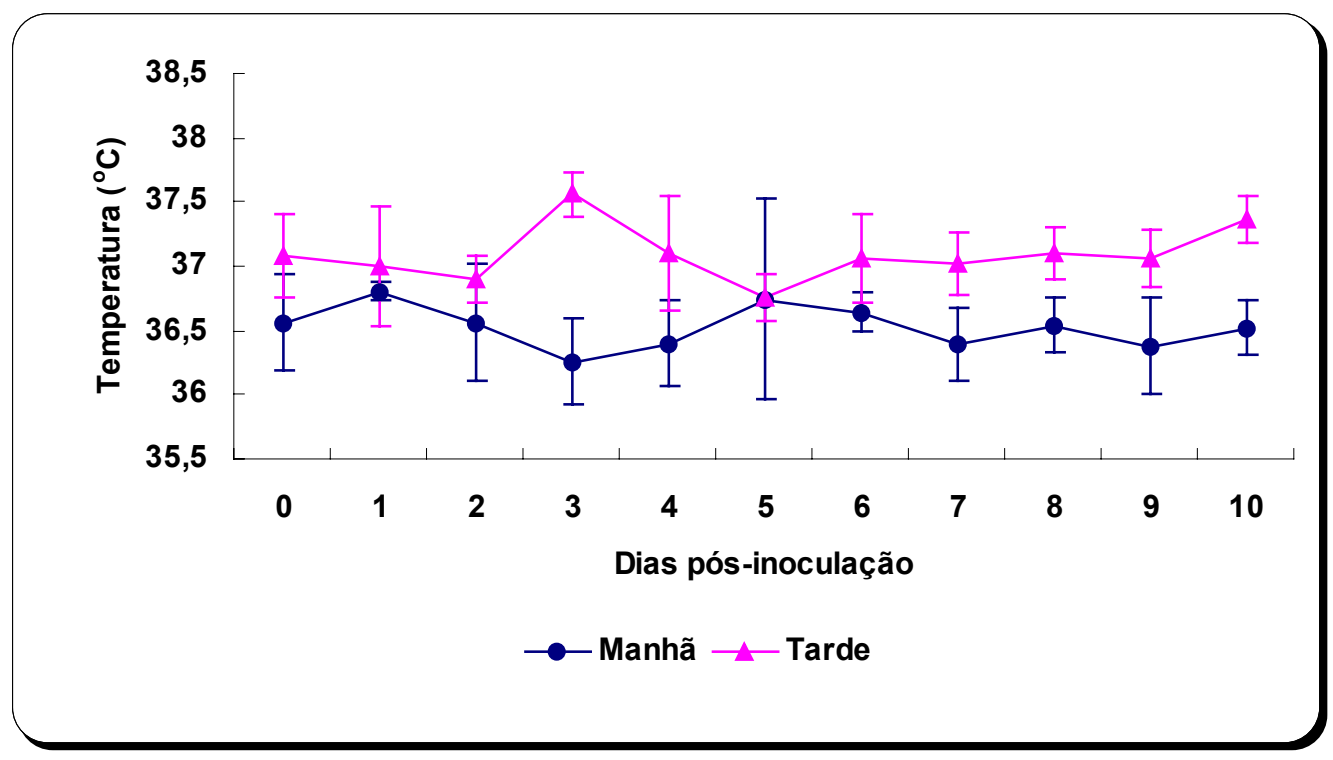

Gráfico 2 - Representação da variação da temperatura corpórea $\left({ }^{\circ} \mathrm{C}\right)$ de cavalos do grupo experimental II inoculados com o herpesvírus eqüino tipo 1 (HVE-1). Os resultados foram expressos em média \pm desvio padrão $(n=5)$. São Paulo, 2004 
No exame endoscópico das vias aéreas anteriores (das narinas até a porção média da traquéia) no quinto dia pós-inoculação (d.p.i.), nenhum animal apresentou alterações macroscópicas que indicassem lesão compatível com infecção viral em relação ao exame realizado no período pré-inoculação (Quadros 8 e 9).

Após duas semanas da inoculação viral, todos as manifestações clínicas observadas desapareceram.

Quadro 8 - $\quad$ Achados macroscópicos observados no exame endoscópico das vias aéreas anteriores de cavalos dos grupos experimentais I e II, no período anterior (dia 0) à inoculação com o herpesvírus eqüino tipo 1 (HVE-1). São Paulo, 2004

\begin{tabular}{|c|c|c|c|c|}
\hline \multirow[t]{2}{*}{ Animal } & \multicolumn{4}{|c|}{ Endoscopia das vias aéreas anteriores } \\
\hline & Mucosa & Vasos sangüíneos & Secreção (tipo) & $\begin{array}{l}\text { Hiperplasia linfóide } \\
\text { faringeana }\end{array}$ \\
\hline 01 & $\begin{array}{l}\text { Avermelhada } \\
\text { (leve hiperemia) }\end{array}$ & $\begin{array}{l}\text { Leve ingurgitamento } \\
\text { em toda a extensão }\end{array}$ & Serosa & Ausente \\
\hline 02 & $\begin{array}{l}\text { Avermelhada } \\
\text { (leve hiperemia) }\end{array}$ & $\begin{array}{l}\text { Leve ingurgitamento } \\
\text { em toda a extensão }\end{array}$ & Seromucosa & Grau 1* \\
\hline 03 & $\begin{array}{l}\text { Avermelhada } \\
\text { (leve hiperemia) }\end{array}$ & $\begin{array}{l}\text { Leve ingurgitamento } \\
\text { em toda a extensão }\end{array}$ & Serosa & Ausente \\
\hline 04 & $\begin{array}{l}\text { Avermelhada } \\
\text { (leve hiperemia) }\end{array}$ & $\begin{array}{l}\text { Leve ingurgitamento } \\
\text { em toda a extensão }\end{array}$ & Serosa & Ausente \\
\hline 05 & $\begin{array}{l}\text { Avermelhada } \\
\text { (leve hiperemia) }\end{array}$ & $\begin{array}{l}\text { Leve ingurgitamento } \\
\text { em toda a extensão }\end{array}$ & Serosa & Ausente \\
\hline 06 & Rósea clara & Sem alterações & Serosa & Ausente \\
\hline 07 & $\begin{array}{l}\text { Avermelhada } \\
\text { (leve hiperemia) }\end{array}$ & $\begin{array}{l}\text { Leve ingurgitamento } \\
\text { em toda a extensão }\end{array}$ & Serosa & Grau 1 \\
\hline 08 & $\begin{array}{l}\text { Avermelhada } \\
\text { (leve hiperemia) }\end{array}$ & $\begin{array}{l}\text { Leve ingurgitamento } \\
\text { em toda a extensão }\end{array}$ & Serosa & Ausente \\
\hline 09 & $\begin{array}{l}\text { Avermelhada } \\
\text { (leve hiperemia) }\end{array}$ & $\begin{array}{l}\text { Leve ingurgitamento } \\
\text { em toda a extensão }\end{array}$ & Serosa & Ausente \\
\hline 10 & $\begin{array}{l}\text { Avermelhada } \\
\text { (leve hiperemia) }\end{array}$ & $\begin{array}{l}\text { Leve ingurgitamento } \\
\text { em toda a extensão }\end{array}$ & Serosa & Ausente \\
\hline
\end{tabular}

*Folículos linfóides inativos em pequena quantidade, pequenos, de coloração esbranquiçada, localizados na parede dorsal da faringe 
Quadro 9 - Achados macroscópicos observados no exame endoscópico das vias aéreas anteriores de cavalos dos grupos experimentais I e II, no quinto dia pósinoculação com o herpesvírus eqüino tipo 1 (HVE-1). São Paulo, 2004

\begin{tabular}{|c|c|c|c|c|}
\hline \multirow[t]{2}{*}{ Animal } & \multicolumn{4}{|c|}{ Endoscopia das vias aéreas anteriores } \\
\hline & Mucosa & Vasos sangüíneos & Secreção (tipo) & $\begin{array}{l}\text { Hiperplasia linfóide } \\
\text { faringeana }\end{array}$ \\
\hline 01 & $\begin{array}{l}\text { Avermelhada } \\
\text { (leve hiperemia) }\end{array}$ & $\begin{array}{l}\text { Leve ingurgitamento } \\
\text { em toda a extensão }\end{array}$ & Seromucosa & Ausente \\
\hline 02 & $\begin{array}{l}\text { Avermelhada } \\
\text { (leve hiperemia) }\end{array}$ & $\begin{array}{l}\text { Leve ingurgitamento } \\
\text { em toda a extensão }\end{array}$ & Seromucosa & Grau $1^{*}$ \\
\hline 03 & $\begin{array}{l}\text { Avermelhada } \\
\text { (leve hiperemia) }\end{array}$ & $\begin{array}{l}\text { Leve ingurgitamento } \\
\text { em toda a extensão }\end{array}$ & Seromucosa & Grau 1 \\
\hline 04 & $\begin{array}{l}\text { Avermelhada } \\
\text { (leve hiperemia) }\end{array}$ & $\begin{array}{l}\text { Leve ingurgitamento } \\
\text { em toda a extensão }\end{array}$ & Seromucosa & Ausente \\
\hline 05 & $\begin{array}{l}\text { Avermelhada } \\
\text { (leve hiperemia) }\end{array}$ & $\begin{array}{l}\text { Leve ingurgitamento } \\
\text { em toda a extensão }\end{array}$ & Seromucosa & Ausente \\
\hline 06 & $\begin{array}{l}\text { Avermelhada } \\
\text { (leve hiperemia) }\end{array}$ & $\begin{array}{l}\text { Leve ingurgitamento } \\
\text { em toda a extensão } \\
\text { Sem alterações }\end{array}$ & Seromucosa & Ausente \\
\hline 07 & $\begin{array}{l}\text { Avermelhada } \\
\text { (leve hiperemia) }\end{array}$ & $\begin{array}{l}\text { Leve ingurgitamento } \\
\text { em toda a extensão }\end{array}$ & Seromucosa & Grau 1 \\
\hline 08 & $\begin{array}{l}\text { Avermelhada } \\
\text { (leve hiperemia) }\end{array}$ & $\begin{array}{l}\text { Leve ingurgitamento } \\
\text { em toda a extensão }\end{array}$ & Seromucosa & Ausente \\
\hline 09 & $\begin{array}{l}\text { Avermelhada } \\
\text { (leve hiperemia) }\end{array}$ & $\begin{array}{l}\text { Leve ingurgitamento } \\
\text { em toda a extensão }\end{array}$ & Seromucosa & Ausente \\
\hline 10 & $\begin{array}{l}\text { Avermelhada } \\
\text { (leve hiperemia) }\end{array}$ & $\begin{array}{l}\text { Leve ingurgitamento } \\
\text { em toda a extensão }\end{array}$ & Seromucosa & Ausente \\
\hline
\end{tabular}

*Folículos linfóides inativos em pequena quantidade, pequenos, de coloração esbranquiçada, localizados na parede dorsal da faringe

\subsection{Hemograma}

Não se observou alteração no eritrograma após a inoculação com o HVE-1.

Também não houve diferenças significativas na análise da média \pm desvio padrão das contagens total e diferencial, em valores absolutos, dos tipos celulares presentes no leucograma dos animais dos grupos experimentais I e II (Tab. 2 e 3). 
Tabela 2 - Contagens total e diferencial do leucograma de cavalos do grupo experimental I inoculados com o herpesvírus eqüino tipo 1 (HVE-1). Os resultados foram expressos em média \pm desvio padrão do número de células $/ \mathrm{mm}^{3}$ (valor absoluto), $\mathrm{n}=5$. São Paulo, 2004

\begin{tabular}{ccccccc}
\hline & & \multicolumn{5}{c}{ Leucócitos } \\
\cline { 3 - 7 } $\begin{array}{c}\text { Dias pós- } \\
\text { inoculação }\end{array}$ & $\begin{array}{c}\text { Leucócitos Totais } \\
\left(\times 10^{3} / \mathrm{mm}^{3}\right)\end{array}$ & $\begin{array}{c}\text { Neutrófilos } \\
\left(\times 10^{3} / \mathrm{mm}^{3}\right)\end{array}$ & $\begin{array}{c}\text { Linfócitos } \\
\left(\times 10^{3} / \mathrm{mm}^{3}\right)\end{array}$ & $\begin{array}{c}\text { Monócitos } \\
\left(\times 10^{2} / \mathrm{mm}^{3}\right)\end{array}$ & $\begin{array}{c}\text { Eosinófilos } \\
\left(\times 10^{2} / \mathrm{mm}^{3}\right)\end{array}$ & $\begin{array}{c}\text { Basófilos } \\
\left(\times 10^{1} / \mathrm{mm}^{3}\right)\end{array}$ \\
\hline 0 & $6,72 \pm 0,65$ & $4,04 \pm 0,33$ & $2,40 \pm 0,52$ & $0,06 \pm 0,14$ & $2,30 \pm 0,69$ & $4,77 \pm 3,88$ \\
01 & $6,72 \pm 1,04$ & $4,00 \pm 0,55$ & $2,57 \pm 0,56$ & $0,00 \pm 0,00$ & $1,38 \pm 1,28$ & $1,18 \pm 1,62$ \\
02 & $6,92 \pm 1,24$ & $4,29 \pm 0,65$ & $2,52 \pm 0,71$ & $0,00 \pm 0,00$ & $0,93 \pm 0,73$ & $2,17 \pm 2,05$ \\
03 & $7,48 \pm 1,33$ & $5,06 \pm 1,41$ & $2,24 \pm 0,56$ & $0,06 \pm 0,13$ & $1,12 \pm 0,96$ & $2,77 \pm 2,66$ \\
04 & $6,84 \pm 1,35$ & $4,42 \pm 1,40$ & $2,35 \pm 0,80$ & $0,06 \pm 0,13$ & $0,47 \pm 0,65$ & $2,24 \pm 2,11$ \\
05 & $7,28 \pm 1,29$ & $5,05 \pm 1,78$ & $2,09 \pm 0,57$ & $0,16 \pm 0,22$ & $1,01 \pm 0,88$ & $2,00 \pm 1,86$ \\
06 & $6,82 \pm 0,55$ & $4,28 \pm 0,29$ & $2,38 \pm 0,50$ & $0,15 \pm 0,20$ & $1,23 \pm 1,01$ & $2,50 \pm 4,05$ \\
07 & $6,62 \pm 1,69$ & $4,16 \pm 1,07$ & $2,32 \pm 0,61$ & $0,00 \pm 0,00$ & $1,34 \pm 0,74$ & $0,54 \pm 1,21$ \\
08 & $6,42 \pm 1,58$ & $4,24 \pm 1,13$ & $2,09 \pm 0,54$ & $0,00 \pm 0,00$ & $0,87 \pm 0,79$ & $0,71 \pm 1,59$ \\
09 & $6,44 \pm 1,21$ & $4,17 \pm 0,80$ & $2,19 \pm 0,63$ & $0,00 \pm 0,00$ & $0,83 \pm 0,48$ & $0,00 \pm 0,00$ \\
10 & $7,14 \pm 1,10$ & $5,05 \pm 0,49$ & $1,90 \pm 0,56$ & $0,00 \pm 0,00$ & $1,70 \pm 0,91$ & $1,83 \pm 2,70$ \\
\hline
\end{tabular}

$p<0,05$ Teste ANOVA de Kruskal-Wallis 
Tabela 3 - $\quad$ Contagem total e diferencial do leucograma de cavalos do grupo experimental II inoculados com o herpesvírus eqüino tipo 1 (HVE-1). Os resultados foram expressos em média \pm desvio padrão do número de células $/ \mathrm{mm}^{3}$ (valor absoluto), n=5. São Paulo, 2004

\begin{tabular}{ccccccc}
\hline & & \multicolumn{5}{c}{ Leucócitos } \\
\cline { 3 - 7 } $\begin{array}{c}\text { Dias pós- } \\
\text { inoculação }\end{array}$ & $\begin{array}{c}\text { Leucócitos Totais } \\
\left(\times 10^{3} / \mathrm{mm}^{3}\right)\end{array}$ & $\begin{array}{c}\text { Neutrófilos } \\
\left(\times 10^{3} / \mathrm{mm}^{3}\right)\end{array}$ & $\begin{array}{c}\text { Linfócitos } \\
\left(\times 10^{3} / \mathrm{mm}^{3}\right)\end{array}$ & $\begin{array}{c}\text { Monócitos } \\
\left(\times 10^{2} / \mathrm{mm}^{3}\right)\end{array}$ & $\begin{array}{c}\text { Eosinófilos } \\
\left(\times 10^{2} / \mathrm{mm}^{3}\right)\end{array}$ & $\begin{array}{c}\text { Basófilos } \\
\left(\times 10^{1} / \mathrm{mm}^{3}\right)\end{array}$ \\
\hline 0 & $6,82 \pm 1,50$ & $4,36 \pm 1,40$ & $2,03 \pm 0,64$ & $1,69 \pm 1,34$ & $2,66 \pm 2,36$ & $0,00 \pm 0,00$ \\
01 & $9,06 \pm 4,15$ & $6,58 \pm 3,84$ & $2,16 \pm 0,96$ & $1,30 \pm 0,55$ & $1,93 \pm 1,22$ & $0,00 \pm 0,00$ \\
02 & $7,34 \pm 1,40$ & $5,35 \pm 1,13$ & $1,71 \pm 0,47$ & $1,73 \pm 1,30$ & $1,09 \pm 0,74$ & $0,00 \pm 0,00$ \\
03 & $8,06 \pm 1,22$ & $5,50 \pm 0,85$ & $2,27 \pm 0,65$ & $2,03 \pm 1,30$ & $0,80 \pm 0,64$ & $0,00 \pm 0,00$ \\
04 & $7,46 \pm 0,89$ & $4,24 \pm 0,80$ & $2,89 \pm 0,75$ & $1,65 \pm 1,08$ & $1,72 \pm 1,45$ & $0,00 \pm 0,00$ \\
05 & $6,84 \pm 0,93$ & $5,31 \pm 1,96$ & $2,23 \pm 0,50$ & $3,68 \pm 3,69$ & $2,60 \pm 2,36$ & $0,00 \pm 0,00$ \\
06 & $6,68 \pm 1,38$ & $3,82 \pm 0,84$ & $2,43 \pm 0,70$ & $2,20 \pm 1,12$ & $1,98 \pm 1,51$ & $1,10 \pm 2,46$ \\
07 & $7,02 \pm 1,27$ & $4,37 \pm 0,70$ & $2,33 \pm 1,22$ & $1,70 \pm 1,18$ & $1,50 \pm 1,14$ & $0,00 \pm 0,00$ \\
08 & $6,38 \pm 1,53$ & $3,92 \pm 0,61$ & $2,10 \pm 1,07$ & $2,32 \pm 2,55$ & $1,06 \pm 0,74$ & $1,66 \pm 3,71$ \\
09 & $7,06 \pm 1,40$ & $4,59 \pm 1,07$ & $2,12 \pm 0,41$ & $1,83 \pm 0,86$ & $1,59 \pm 1,75$ & $1,50 \pm 3,35$ \\
10 & $6,52 \pm 1,43$ & $3,91 \pm 1,10$ & $2,23 \pm 0,54$ & $2,23 \pm 2,19$ & $1,53 \pm 2,36$ & $0,00 \pm 0,00$ \\
\hline
\end{tabular}

$p<0,05$ Teste ANOVA de Kruskal-Wallis

Em relação aos animais analisados individualmente, foram observadas alterações na contagem de leucócitos totais, neutrófilos e linfócitos. O animal 06 apresentou leucocitose no primeiro d.p.i. Já os animais 04, 09 e 10 apresentaram leucopenia em diferentes dias, com maior ocorrência entre o sexto e o décimo d.p.i. (Quadro 10; Graf. 3 e 4). O animal 05 apresentou neutrofilia no quinto d.p.i e o animal 06 no primeiro d.p.i. (Quadro 11, Graf. 5 e 6). Observou-se linfopenia nos animais 02, 05, 08, 09 e 10, em diferentes dias pós-inoculação (Quadro 12; Graf. 7 e 8). 
Quadro 10 - Contagem dos leucócitos sangüíneos totais de cavalos dos grupos experimentais I e II inoculados com o herpesvírus eqüino tipo 1 (HVE-1). Os resultados foram expressos em número de células $/ \mathrm{mm}^{3}$. São Paulo, 2004

\begin{tabular}{|c|c|c|c|c|c|c|c|c|c|c|}
\hline \multicolumn{11}{|c|}{ Leucócitos Sangüíneos Totais $\left(\times 10^{3} / \mathrm{mm}^{3}\right)$} \\
\hline \multirow[b]{2}{*}{$\begin{array}{l}\text { Dias pós- } \\
\text { inoculação }\end{array}$} & \multicolumn{5}{|c|}{ Grupo I } & \multicolumn{5}{|c|}{ Grupo II } \\
\hline & 01 & 02 & 03 & 04 & 05 & 06 & 07 & 08 & 09 & 10 \\
\hline 0 & 7,80 & 6,40 & 6,50 & 6,80 & 6,10 & 7,30 & 8,50 & 7,80 & $5,20^{\mathrm{L}}$ & 5,30 \\
\hline 01 & 7,80 & 5,90 & 5,90 & 7,90 & 6,10 & $16,3^{\text {Lc }}$ & 8,30 & 6,90 & 7,90 & 5,90 \\
\hline 02 & 8,80 & 5,90 & 7,00 & 7,20 & 5,70 & 9,20 & 8,00 & 7,60 & 5,90 & 6,00 \\
\hline 03 & 8,40 & 5,80 & 6,90 & 9,20 & 7,10 & 9,00 & 8,90 & 8,90 & 6,40 & 7,10 \\
\hline 04 & 8,00 & 5,80 & 5,80 & 8,60 & 6,00 & 7,20 & 8,40 & 8,40 & 6,60 & 6,70 \\
\hline 05 & 7,20 & 5,80 & 7,70 & 6,50 & 9,20 & 7,20 & 6,30 & 8,30 & 6,00 & 6,40 \\
\hline 06 & 7,60 & 6,20 & 6,90 & 7,00 & 6,40 & 6,50 & 8,10 & 8,10 & $5,20^{\mathrm{L}}$ & 5,50 \\
\hline 07 & 9,30 & 5,70 & 7,30 & 5,40 & 5,40 & 6,20 & 8,40 & 8,40 & 5,90 & 6,20 \\
\hline 08 & 8,80 & 5,60 & 7,10 & $4,70^{\mathrm{L}}$ & 5,90 & 7,60 & 8,30 & 6,10 & $4,80^{\mathrm{L}}$ & $5,10^{\mathrm{L}}$ \\
\hline 09 & 8,50 & 5,80 & 6,50 & 5,50 & 5,90 & 8,30 & 8,30 & 7,50 & $5,20^{\mathrm{L}}$ & 6,00 \\
\hline 10 & 8,80 & 6,00 & 7,40 & 7,20 & 6,30 & 8,10 & 7,90 & 6,30 & $5,10^{\mathrm{L}}$ & $5,20^{\mathrm{L}}$ \\
\hline
\end{tabular}

L: leucopenia

Lc: leucocitose 


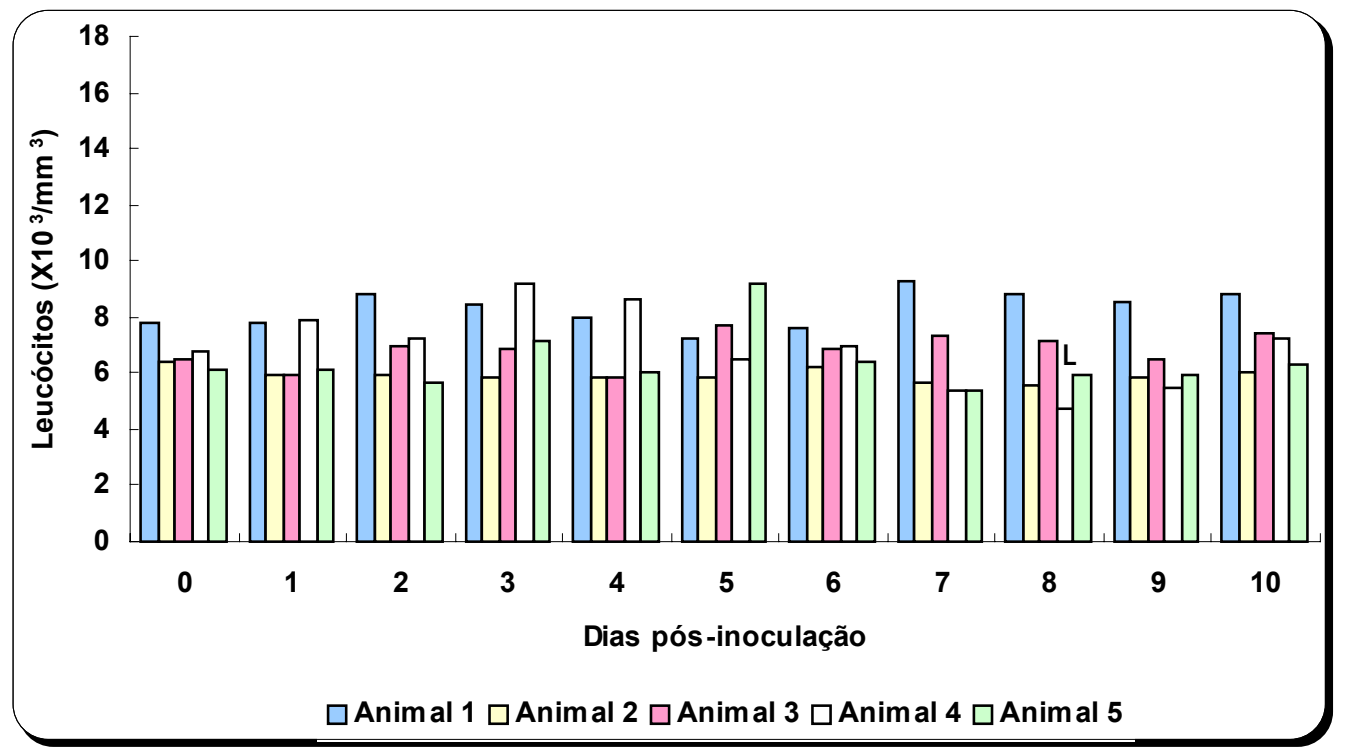

Gráfico 3 - Contagem dos leucócitos sangüíneos totais de cavalos do grupo experimental I inoculados com o herpesvírus eqüino tipo 1 (HVE-1). Os resultados foram expressos em número de células $/ \mathrm{mm}^{3}$. São Paulo, 2004 L: leucopenia

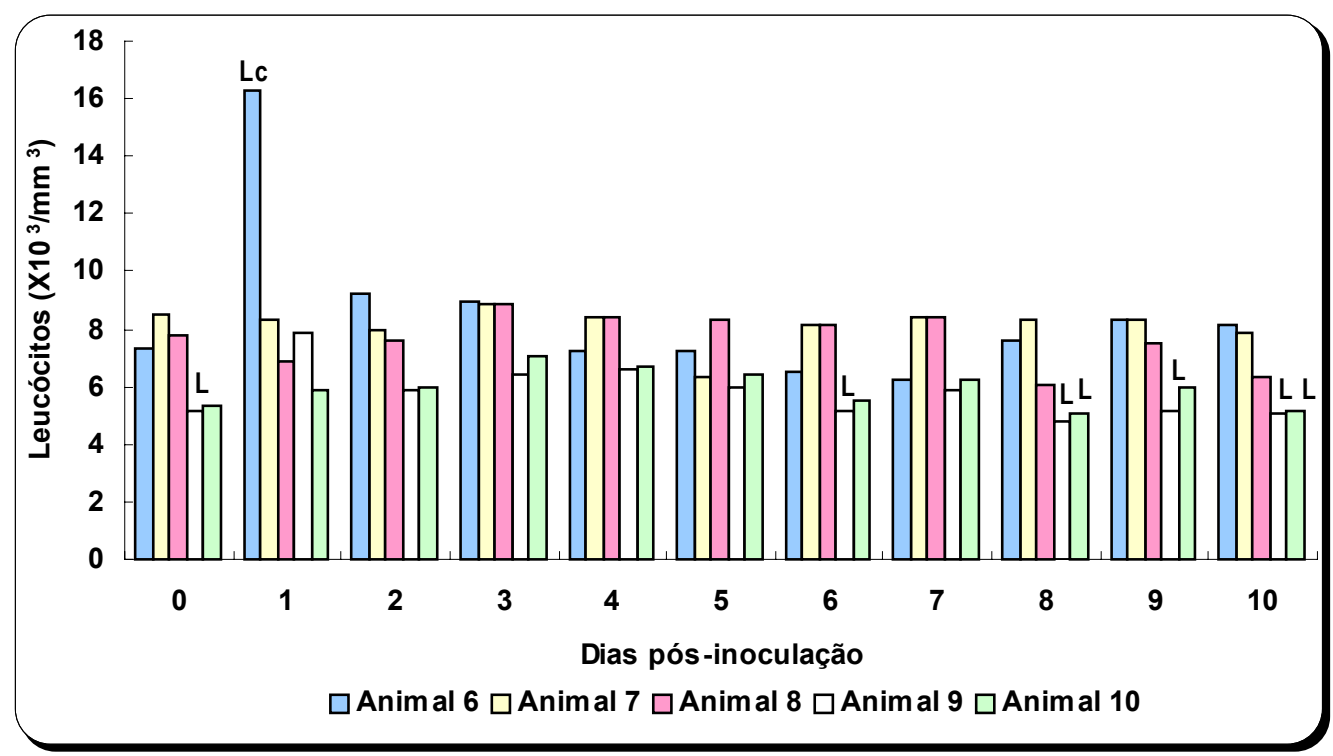

Gráfico 4 - Contagem dos leucócitos sangüíneos totais de cavalos do grupo experimental II inoculados com o herpesvírus eqüino tipo 1 (HVE-1). Os resultados foram expressos em número de células $/ \mathrm{mm}^{3}$. São Paulo, 2004

L: leucopenia

Lc: leucocitose 
Quadro 11 - Contagem diferencial dos neutrófilos sangüíneos de cavalos dos grupos experimentais I e II inoculados com o herpesvírus eqüino tipo 1 (HVE-1). Os resultados foram expressos em número de células $/ \mathrm{mm}^{3}$ (valor absoluto). São Paulo, 2004

\begin{tabular}{|c|c|c|c|c|c|c|c|c|c|c|}
\hline \multicolumn{11}{|c|}{ Neutrófilos Sangüíneos $\left(\times 10^{3} / \mathrm{mm}^{3}\right)$} \\
\hline \multirow[b]{2}{*}{$\begin{array}{l}\text { Dias pós- } \\
\text { inoculação }\end{array}$} & \multicolumn{5}{|c|}{ Grupo I } & \multicolumn{5}{|c|}{ Grupo II } \\
\hline & 01 & 02 & 03 & 04 & 05 & 06 & 07 & 08 & 09 & 10 \\
\hline 0 & 4,37 & 4,19 & 3,70 & 4,25 & 3,66 & 4,31 & 5,70 & 5,85 & 2,96 & 2,97 \\
\hline 01 & 4,60 & 4,10 & 3,21 & 4,38 & 3,72 & $13,4^{\mathrm{N}}$ & 4,57 & 4,76 & 5,85 & 4,37 \\
\hline 02 & 5,20 & 3,63 & 4,69 & 4,17 & 3,76 & 7,08 & 5,20 & 5,70 & 4,43 & 4,32 \\
\hline 03 & 5,21 & 3,45 & 4,35 & 7,27 & 5,04 & 5,49 & 6,32 & 6,23 & 4,22 & 5,25 \\
\hline 04 & 4,44 & 2,78 & 3,88 & 6,62 & 4,35 & 3,53 & 5,04 & 4,62 & 3,23 & 4,76 \\
\hline 05 & 4,21 & 3,48 & 5,50 & 4,09 & $7,96^{\mathrm{N}}$ & 3,96 & 3,78 & 4,15 & 3,72 & 4,29 \\
\hline 06 & 4,22 & 3,90 & 4,31 & 4,72 & 4,22 & 3,12 & 4,86 & 4,62 & 3,28 & 3,25 \\
\hline 07 & 5,72 & 3,76 & 4,78 & 3,21 & 3,32 & 3,47 & 3,86 & 5,21 & 4,60 & 4,71 \\
\hline 08 & 5,67 & 4,14 & 4,90 & 2,70 & 3,77 & 3,65 & 4,65 & 4,45 & 3,70 & 3,16 \\
\hline 09 & 5,27 & 3,94 & 4,52 & 3,08 & 4,04 & 5,15 & 5,81 & 5,03 & 3,22 & 3,72 \\
\hline 10 & 5,76 & 4,59 & 5,18 & 5,11 & 4,60 & 4,78 & 4,98 & 4,16 & 3,37 & 2,29 \\
\hline
\end{tabular}

$\mathrm{N}$ : neutrofilia 


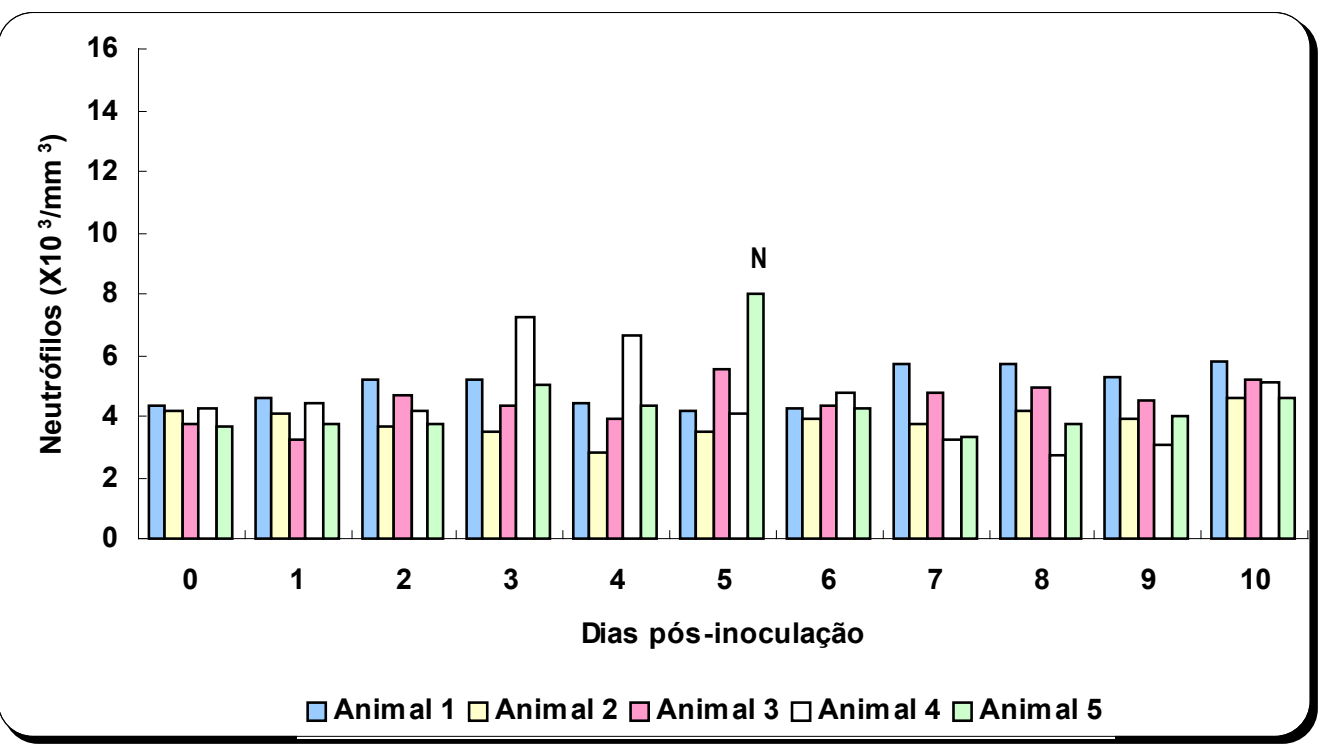

Gráfico 5 - Contagem diferencial dos neutrófilos sangüíneos de cavalos do grupo experimental I inoculados com o herpesvírus eqüino tipo 1 (HVE-1). Os resultados foram expressos em número de células $/ \mathrm{mm}^{3}$ (valor absoluto). São Paulo, 2004

$\mathrm{N}$ : neutrofilia

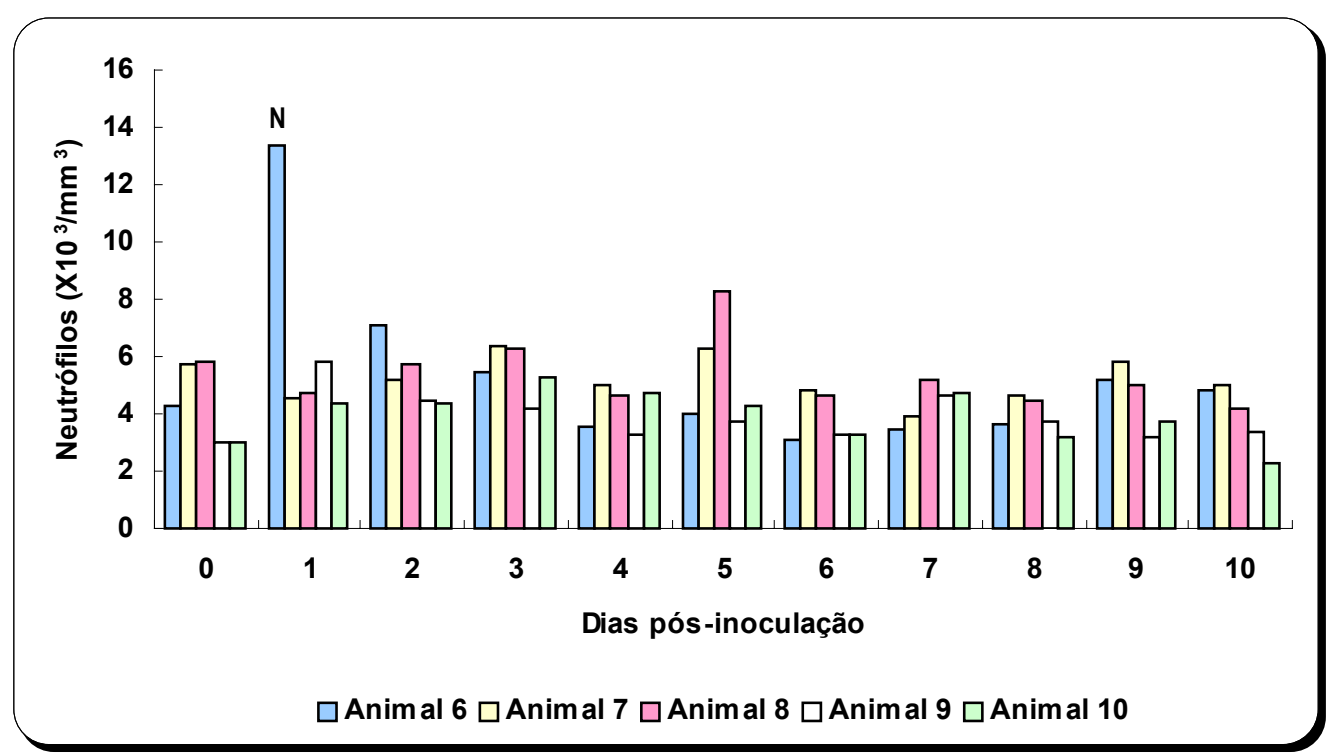

Gráfico 6 - Contagem diferencial dos neutrófilos sangüíneos de cavalos do grupo experimental II inoculados com o herpesvírus eqüino tipo 1 (HVE-1). Os resultados foram expressos em número de células $/ \mathrm{mm}^{3}$ (valor absoluto). São Paulo, 2004

$\mathrm{N}$ : neutrofilia 
Quadro 12 - Contagem diferencial dos linfócitos sangüíneos de cavalos dos grupos experimentais I e II inoculados com o herpesvírus eqüino tipo 1 (HVE-1). Os resultados foram expressos em número de células $/ \mathrm{mm}^{3}$ (valor absoluto). São Paulo, 2004

\begin{tabular}{|c|c|c|c|c|c|c|c|c|c|c|}
\hline \multicolumn{11}{|c|}{ Linfócitos Sangüíneos $\left(\times 10^{3} / \mathrm{mm}^{3}\right)$} \\
\hline \multirow[b]{2}{*}{$\begin{array}{c}\text { Dias pós- } \\
\text { inoculação }\end{array}$} & \multicolumn{5}{|c|}{ Grupo I } & \multicolumn{5}{|c|}{ Grupo II } \\
\hline & 01 & 02 & 03 & 04 & 05 & 06 & 07 & 08 & 09 & 10 \\
\hline 0 & 3,16 & 1,79 & 2,57 & 2,38 & 2,10 & 2,85 & 2,38 & $1,25^{\mathrm{L}}$ & 2,13 & 1,54 \\
\hline 01 & 3,00 & 1,77 & 2,51 & 3,20 & 2,35 & 2,61 & 3,57 & 1,59 & 1,90 & $1,12^{\mathrm{L}}$ \\
\hline 02 & 3,52 & 2,12 & 2,06 & 3,00 & 1,88 & 1,66 & 2,48 & 1,75 & $1,36^{\mathrm{L}}$ & $1,32^{\mathrm{L}}$ \\
\hline 03 & 3,11 & 2,20 & 2,31 & 1,61 & 1,95 & 3,33 & 2,14 & 2,40 & 1,79 & 1,70 \\
\hline 04 & 3,40 & 3,01 & 1,74 & 1,93 & 1,65 & 3,53 & 2,86 & 3,28 & 3,17 & 1,61 \\
\hline 05 & 2,77 & 2,20 & 2,12 & 2,18 & $1,19^{\mathrm{L}}$ & 2,95 & 2,02 & 2,49 & 2,04 & 1,66 \\
\hline 06 & 3,27 & 2,08 & 2,28 & 2,13 & 2,14 & 3,19 & 2,67 & 2,92 & 1,72 & 1,65 \\
\hline 07 & 3,35 & 1,85 & 2,41 & 2,00 & 2,00 & 2,48 & 4,12 & 2,69 & $1,18^{\mathrm{L}}$ & $1,18^{\mathrm{L}}$ \\
\hline 08 & 2,90 & $1,40^{\mathrm{L}}$ & 2,13 & 1,90 & 2,09 & 3,57 & 2,82 & $1,28^{\mathrm{L}}$ & $1,01^{\mathrm{L}}$ & 1,84 \\
\hline 09 & 3,23 & 1,77 & 1,88 & 2,31 & 1,74 & 2,82 & 2,16 & 1,88 & 1,87 & 1,86 \\
\hline 10 & 2,73 & $1,26^{\mathrm{L}}$ & 2,11 & 1,87 & 1,54 & 2,67 & 2,84 & 1,76 & 1,63 & 2,24 \\
\hline
\end{tabular}

L: linfopenia 


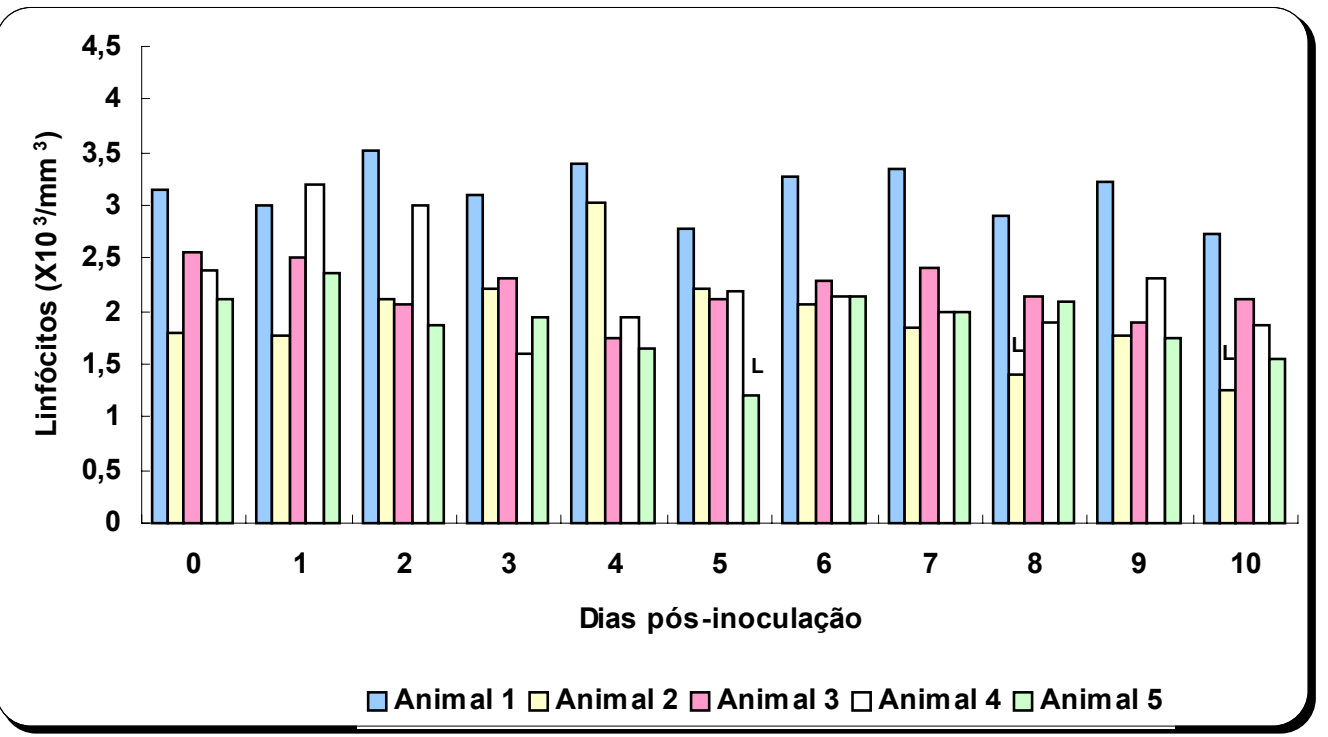

Gráfico 7 - Contagem diferencial dos linfócitos sangüíneos de cavalos do grupo experimental I inoculados com o herpesvírus eqüino tipo 1 (HVE-1). Os resultados foram expressos em número de células $/ \mathrm{mm}^{3}$ (valor absoluto). São Paulo, 2004

L: linfopenia

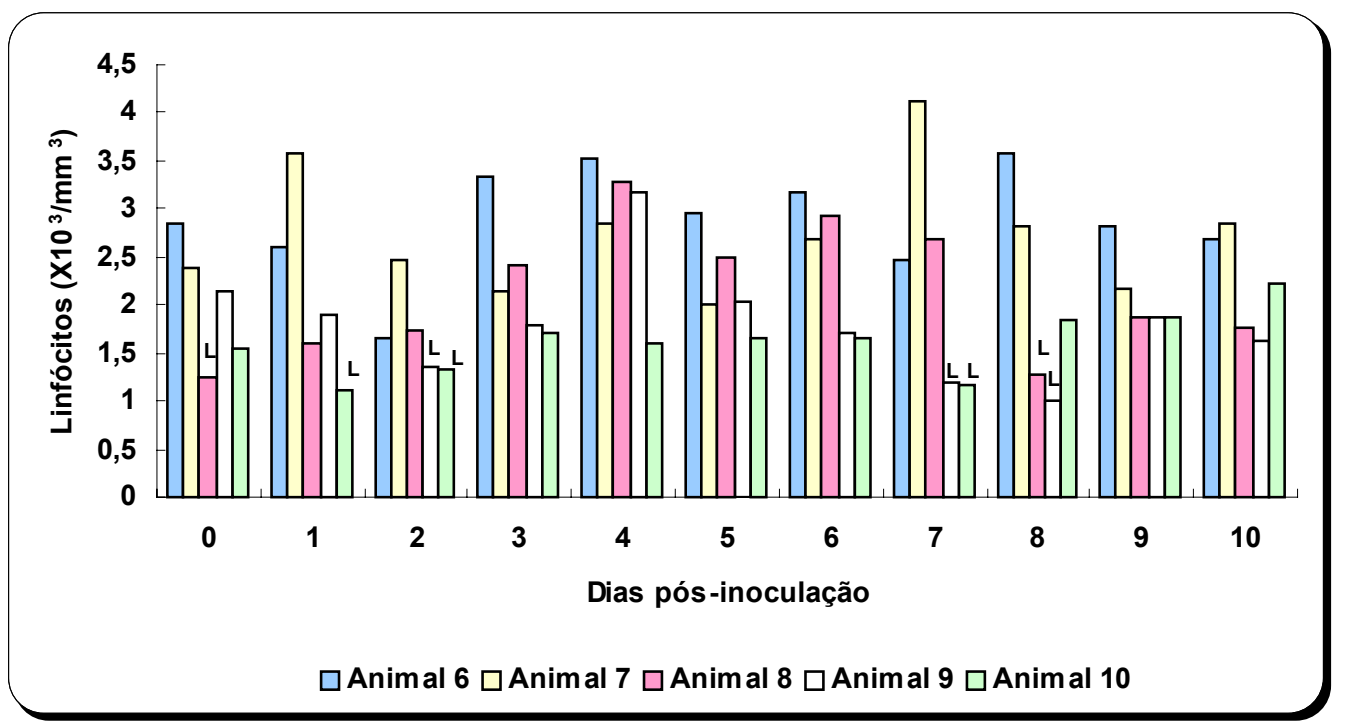

Gráfico 8 - Contagem diferencial dos linfócitos sangüíneos de cavalos do grupo experimental II inoculados com o herpesvírus eqüino tipo 1 (HVE-1). Os resultados foram expressos em número de células $/ \mathrm{mm}^{3}$ (valor absoluto). São Paulo, 2004

L: linfopenia 
Quadro 13 - Contagem diferencial dos monócitos sangüíneos de cavalos dos grupos experimentais I e II inoculados com o herpesvírus eqüino tipo 1 (HVE-1). Os resultados foram expressos em número de células $/ \mathrm{mm}^{3}$ (valor absoluto). São Paulo, 2004

\begin{tabular}{|c|c|c|c|c|c|c|c|c|c|c|}
\hline \multicolumn{11}{|c|}{ Monócitos Sangüíneos $\left(\times 10^{2} / \mathrm{mm}^{3}\right)$} \\
\hline \multirow[b]{2}{*}{$\begin{array}{l}\text { Dias pós- } \\
\text { inoculação }\end{array}$} & \multicolumn{5}{|c|}{ Grupo I } & \multicolumn{5}{|c|}{ Grupo II } \\
\hline & 01 & 02 & 03 & 04 & 05 & 06 & 07 & 08 & 09 & 10 \\
\hline 0 & 0,00 & 0,32 & 0,00 & 0,00 & 0,00 & 0,73 & 1,70 & 3,90 & 0,52 & 1,59 \\
\hline 01 & 0,00 & 0,00 & 0,00 & 0,00 & 0,00 & 1,63 & 0,83 & 2,07 & 0,79 & 1,18 \\
\hline 02 & 0,00 & 0,00 & 0,00 & 0,00 & 0,00 & 3,68 & 2,40 & 0,76 & 0,59 & 1,20 \\
\hline 03 & 0,00 & 0,29 & 0,00 & 0,00 & 0,00 & 1,80 & 3,56 & 0,89 & 3,20 & 0,71 \\
\hline 04 & 0,00 & 0,00 & 0,29 & 0,00 & 0,00 & 0,72 & 3,36 & 0,84 & 1,32 & 2,01 \\
\hline 05 & 0,00 & 0,00 & 0,00 & 0,32 & 0,46 & 2,16 & 3,78 & 9,96 & 0,60 & 1,92 \\
\hline 06 & 0,38 & 0,00 & 0,34 & 0,00 & 0,00 & 1,30 & 2,43 & 4,05 & 1,56 & 1,65 \\
\hline 07 & 0,00 & 0,00 & 0,00 & 0,00 & 0,00 & 1,24 & 0,84 & 3,36 & 0,59 & 2,48 \\
\hline 08 & 0,00 & 0,00 & 0,00 & 0,00 & 0,00 & 1,52 & 6,64 & 2,44 & 0,48 & 0,51 \\
\hline 09 & 0,00 & 0,00 & 0,00 & 0,00 & 0,00 & 2,49 & 2,49 & 0,75 & 1,04 & 2,40 \\
\hline 10 & 0,00 & 0,00 & 0,00 & 0,00 & 0,00 & 5,67 & 0,79 & 3,15 & 0,51 & 1,04 \\
\hline
\end{tabular}


Quadro 14 - Contagem diferencial dos eosinófilos sangüíneos de cavalos dos grupos experimentais I e II inoculados com o herpesvírus eqüino tipo 1 (HVE-1). Os resultados foram expressos em número de células $/ \mathrm{mm}^{3}$ (valor absoluto). São Paulo, 2004

\begin{tabular}{|c|c|c|c|c|c|c|c|c|c|c|}
\hline \multicolumn{11}{|c|}{ Eosinófilos Sangüíneos $\left(\times 10^{2} / \mathrm{mm}^{3}\right)$} \\
\hline \multirow[b]{2}{*}{$\begin{array}{l}\text { Dias pós- } \\
\text { inoculação }\end{array}$} & \multicolumn{5}{|c|}{ Grupo I } & \multicolumn{5}{|c|}{ Grupo II } \\
\hline & 01 & 02 & 03 & 04 & 05 & 06 & 07 & 08 & 09 & 10 \\
\hline 0 & 0,19 & 2,88 & 2,28 & 1,36 & 3,05 & 0,73 & 2,55 & 3,12 & 0,52 & 6,36 \\
\hline 01 & 0,19 & 0,00 & 1,47 & 3,16 & 0,30 & 1,63 & 0,83 & 3,45 & 0,79 & 2,95 \\
\hline 02 & 0,44 & 1,18 & 2,10 & 0,36 & 0,57 & 0,92 & 0,80 & 0,76 & 0,59 & 2,40 \\
\hline 03 & 0,84 & 0,50 & 0,34 & 2,76 & 1,06 & 0,00 & 0,89 & 1,78 & 0,64 & 0,71 \\
\hline 04 & 1,20 & 0,00 & 1,16 & 0,00 & 0,00 & 0,72 & 1,68 & 4,20 & 0,66 & 1,34 \\
\hline 05 & 2,16 & 0,87 & 0,38 & 1,62 & 0,00 & 0,72 & 1,26 & 6,64 & 1,80 & 2,56 \\
\hline 06 & 0,76 & 1,24 & 2,76 & 1,40 & 0,00 & 0,65 & 3,24 & 1,62 & 0,52 & 3,85 \\
\hline 07 & 2,32 & 0,85 & 1,09 & 1,89 & 0,54 & 1,24 & 3,36 & 1,68 & 0,59 & 0,62 \\
\hline 08 & 2,20 & 0,56 & 0,35 & 0,94 & 0,29 & 2,28 & 0,83 & 1,22 & 0,48 & 0,51 \\
\hline 09 & 0,00 & 0,87 & 0,97 & 1,10 & 1,18 & 0,83 & 0,83 & 4,50 & 0,00 & 1,80 \\
\hline 10 & 3,08 & 0,90 & 1,11 & 2,16 & 1,26 & 0,81 & 0,00 & 0,63 & 0,51 & 5,72 \\
\hline
\end{tabular}


Quadro 15 - Contagem diferencial dos basófilos sangüíneos de cavalos dos grupos experimentais I e II inoculados com o herpesvírus eqüino tipo 1 (HVE-1). Os resultados foram expressos em número de células $/ \mathrm{mm}^{3}$ (valor absoluto). São Paulo, 2004

\begin{tabular}{|c|c|c|c|c|c|c|c|c|c|c|}
\hline \multicolumn{11}{|c|}{ Basófilos Sangüíneos $\left(\times 10^{1} / \mathrm{mm}^{3}\right)$} \\
\hline \multirow[b]{2}{*}{$\begin{array}{l}\text { Dias pós- } \\
\text { inoculação }\end{array}$} & \multicolumn{5}{|c|}{ Grupo I } & \multicolumn{5}{|c|}{ Grupo II } \\
\hline & 01 & 02 & 03 & 04 & 05 & 06 & 07 & 08 & 09 & 10 \\
\hline 0 & 7,80 & 9,60 & 0,00 & 3,40 & 3,05 & 0,00 & 0,00 & 0,00 & 0,00 & 0,00 \\
\hline 01 & 0,00 & 2,95 & 2,95 & 0,00 & 0,00 & 0,00 & 0,00 & 0,00 & 0,00 & 0,00 \\
\hline 02 & 4,40 & 2,95 & 3,50 & 0,00 & 0,00 & 0,00 & 0,00 & 0,00 & 0,00 & 0,00 \\
\hline 03 & 0,00 & 5,80 & 3,45 & 4,60 & 0,00 & 0,00 & 0,00 & 0,00 & 0,00 & 0,00 \\
\hline 04 & 4,00 & 0,00 & 2,90 & 4,30 & 0,00 & 0,00 & 0,00 & 0,00 & 0,00 & 0,00 \\
\hline 05 & 0,00 & 2,90 & 3,85 & 3,25 & 0,00 & 0,00 & 0,00 & 0,00 & 0,00 & 0,00 \\
\hline 06 & 0,00 & 9,30 & 0,00 & 0,00 & 3,20 & 0,00 & 0,00 & 0,00 & 0,00 & 5,50 \\
\hline 07 & 0,00 & 0,00 & 0,00 & 0,00 & 2,70 & 0,00 & 0,00 & 0,00 & 0,00 & 0,00 \\
\hline 08 & 0,00 & 0,00 & 3,55 & 0,00 & 0,00 & 0,00 & 8,30 & 0,00 & 0,00 & 0,00 \\
\hline 09 & 0,00 & 0,00 & 0,00 & 0,00 & 0,00 & 0,00 & 0,00 & 7,50 & 0,00 & 0,00 \\
\hline 10 & 0,00 & 6,00 & 0,00 & 0,00 & 3,15 & 0,00 & 0,00 & 0,00 & 0,00 & 0,00 \\
\hline
\end{tabular}




\subsection{Prova de SoRodiagnóstico PaRa o HVE-1}

A análise da média \pm desvio-padrão para a prova de soroneutralização viral não apontou diferença significativa entre os títulos de anticorpos soroneutralizantes contra HVE-1 nos grupos experimentais I e II (Tab. 4 e 5).

Em relação aos resultados analisados individualmente, houve aumento maior que $10^{0,6}$ nos títulos de anticorpos soroneutralizantes contra o HVE-1 entre os dias $+14,+21$ e +28 pós-inoculação nos animais $02,03,08,09$ e 10 quando comparados com o período pré-inoculação (Quadro 16; Graf. 9 e 10).

Tabela 4 - Títulos de anticorpos soroneutralizantes contra o herpesvírus eqüino tipo 1 (HVE-1) em soros sangüíneos de cavalos do grupo experimental I. Os resultados foram expressos em média \pm desvio padrão $\left(\log _{10}\right), n=5$. São Paulo, 2004

\begin{tabular}{ccccccc}
\hline \multicolumn{7}{c}{ Títulos de Anticorpos $\left(\log _{10}\right)$} \\
\hline \multicolumn{7}{c}{ Dias pós-inoculação } \\
\hline-21 & -14 & 0 & +07 & +14 & +21 & +28 \\
\hline- & $0,8 \pm 0,5$ & $0,8 \pm 0,5$ & $0,8 \pm 0,5$ & $1,4 \pm 0,5$ & $1,2 \pm 0,5$ & $1,3 \pm 0,4$
\end{tabular}

$p<0,05$ Teste ANOVA de Kruskal-Wallis

Tabela 5 - $\quad$ Títulos de anticorpos soroneutralizantes contra o herpesvírus eqüino tipo 1 (HVE-1) em soros sangüíneos de cavalos do grupo experimental II. Os resultados foram expressos em média \pm desvio padrão $\left(\log _{10}\right), n=5$. São Paulo, 2004

\begin{tabular}{ccccccc}
\hline \multicolumn{7}{c}{ Títulos de Anticorpos $\left(\log _{10}\right)$} \\
\hline \multicolumn{7}{c}{ Dias pós-inoculação } \\
\hline-21 & -14 & 0 & +07 & +14 & +21 & +28 \\
\hline $1,5 \pm 0,2$ & $1,3 \pm 0,3$ & $1,5 \pm 0,6$ & $1,6 \pm 0,7$ & $2,1 \pm 0,6$ & $1,9 \pm 0,5$ & $1,8 \pm 0,6$
\end{tabular}

$p<0,05$ Teste ANOVA de Kruskal-Wallis 
Quadro 16 - Títulos de anticorpos soroneutralizantes contra o herpesvírus eqüino tipo 1 (HVE-1) em soros sangüíneos de cavalos dos grupos experimentais I e II. Os resultados foram expressos em $\log _{10}$. São Paulo, 2004

\begin{tabular}{|c|c|c|c|c|c|c|c|c|c|c|}
\hline \multicolumn{11}{|c|}{ Títulos de Anticorpos $\left(\log _{10}\right)$} \\
\hline \multirow[b]{2}{*}{$\begin{array}{l}\text { Dias pós- } \\
\text { inoculação }\end{array}$} & \multicolumn{5}{|c|}{ Grupo I } & \multicolumn{5}{|c|}{ Grupo II } \\
\hline & 01 & 02 & 03 & 04 & 05 & 06 & 07 & 08 & 09 & 10 \\
\hline-21 & - & - & - & - & - & 1,8 & 1,2 & 1,5 & 1,5 & - \\
\hline-14 & 1,2 & 0,0 & 0,7 & 1,0 & 1,0 & 1,8 & 1,0 & 1,2 & 1,2 & 1,2 \\
\hline 0 & 1,0 & 0,0 & 0,7 & 1,0 & 1,2 & 2,4 & 1,0 & 1,5 & 1,5 & 1,0 \\
\hline+07 & 1,0 & 0,0 & 1,0 & 1,2 & 1,0 & 2,7 & 1,0 & 1,8 & 1,8 & 1,0 \\
\hline+14 & 1,5 & $0,7^{\mathrm{s}}$ & $2,1^{\mathrm{s}}$ & 1,5 & 1,0 & 2,7 & 1,2 & 1,8 & $2,7^{\mathrm{s}}$ & $1,8^{\mathrm{s}}$ \\
\hline+21 & 1,2 & $0,7^{\mathrm{s}}$ & $2,1^{\mathrm{s}}$ & 1,0 & 1,2 & 2,4 & 1,5 & $2,1^{\mathrm{s}}$ & $2,1^{\mathrm{s}}$ & 1,2 \\
\hline+28 & 1,0 & $1,0^{\mathrm{s}}$ & $1,8^{\mathbf{s}}$ & 1,5 & 1,2 & 2,7 & 1,2 & 1,8 & 1,8 & 1,2 \\
\hline
\end{tabular}

s: soroconversão

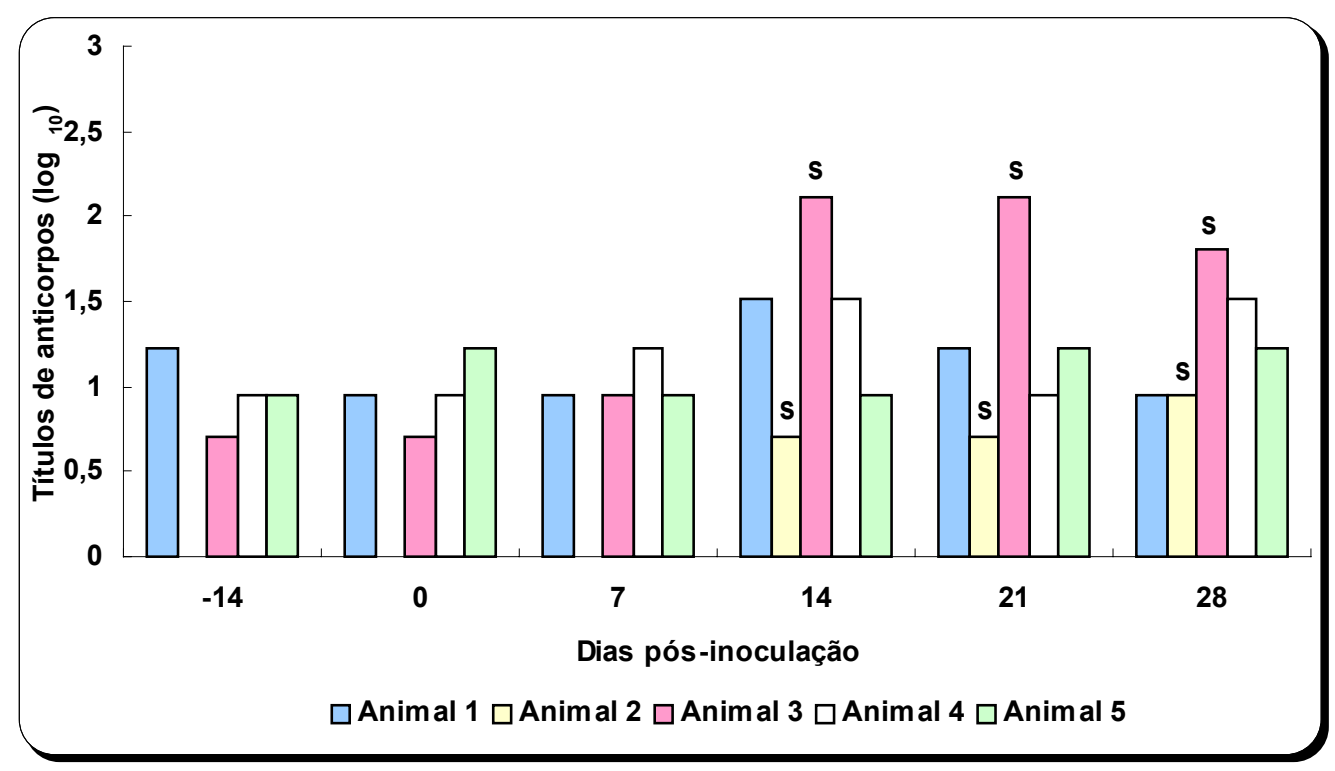

Gráfico 9 - Representação dos títulos de anticorpos soroneutralizantes contra o herpesvírus eqüino tipo 1 (HVE-1) em soros sangüíneos de cavalos do grupo experimental I. Os resultados foram expressos em $\log _{10}$. São Paulo, 2004 s: soroconversão 


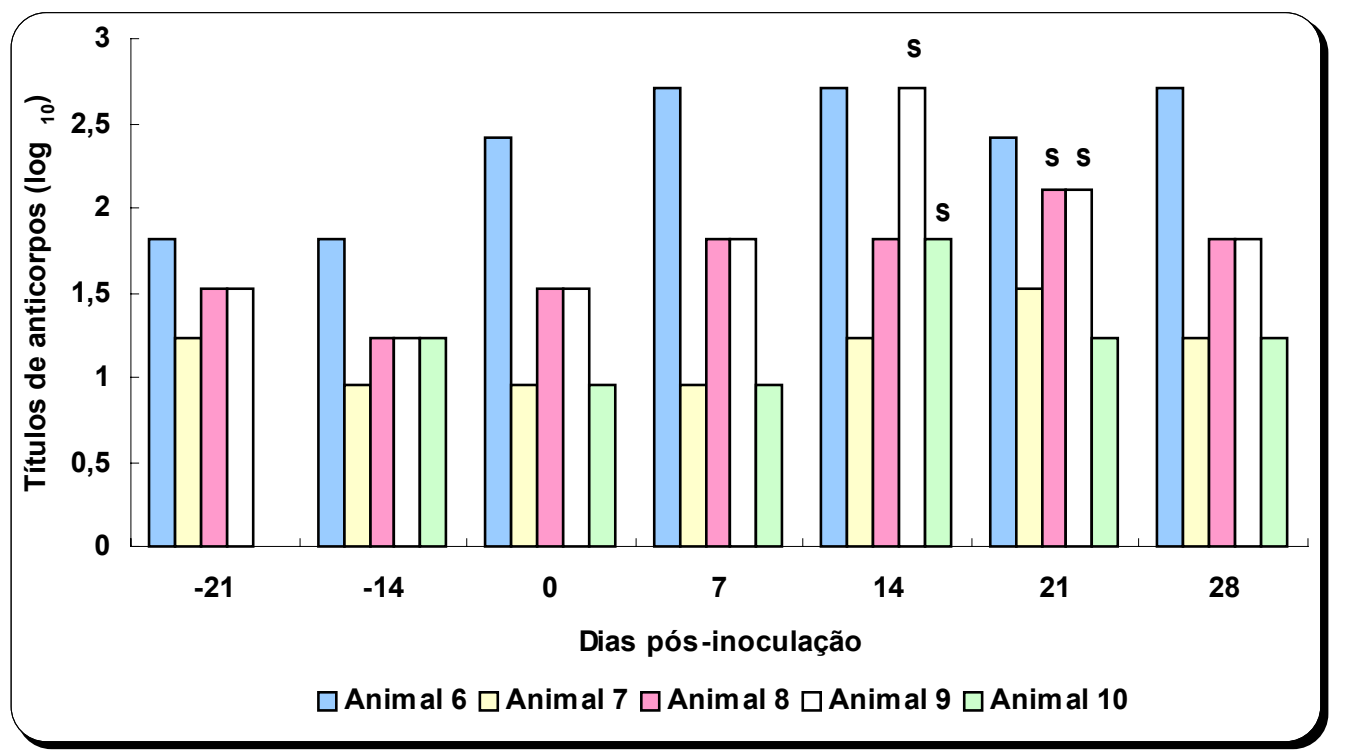

Gráfico 10 - Representação dos títulos de anticorpos soroneutralizantes contra o herpesvírus eqüino tipo 1 (HVE-1) em soros sangüíneos de cavalos do grupo experimental II. Os resultados foram expressos em $\log _{10}$. São Paulo, 2004 s: soroconversão

\subsection{ISOLAMENTO DO HVE-1}

Todas as amostras de secreções nasais, colhidas nos dez primeiros dias pósinoculação com HVE-1, apresentaram isolamento viral negativo em cultura de células VERO.

\subsection{Citologia do lavado Broncoalveolar (LBA)}

Os macrófagos alveolares apresentaram diferenças morfológicas no transcorrer dos experimentos: no início (dias -7 e +2 pós-inoculação com HVE-1) eles geralmente eram pequenos, de formato esférico e regular, com ausência de projeções e de vacúolos citoplasmáticos (Fig. 6). No final do período experimental 
(dias +23 e +30 pós-inoculação) os macrófagos tornaram-se maiores, com grande número de vacúolos dispersos no citoplasma - o que lhes dava um aspecto espumoso -, além de apresentarem mais comumente partículas fagocitadas no interior do citoplasma e formas bi, tri e multinucleadas (Fig. 7, 8, 9 e 10).

De modo geral, na citologia do LBA os macrófagos foram o tipo celular predominante em ambos os grupos. Em segundo lugar observou-se a presença de linfócitos e, em menor número, foram encontrados neutrófilos, eosinófilos e mastócitos (Fig. 11).

A análise da média \pm desvio padrão da contagem diferencial de células alveolares não revelou diferença significativa entre os animais dos grupos experimentais I e II após a inoculação com HVE-1 (Tab. 6 e 7).

Ao analisar os resultados da citologia do LBA obtidos individualmente, foram observadas diminuição do número dos macrófagos alveolares no animal 07 no décimo sexto d.p.i. (Quadro 17; Graf. 12), neutrofilia nos animais 03, 05, 06 e 07 em diferentes dias experimentais (Quadro 19; Graf. 13 e 14); o animal 10 apresentou um grande número de eosinófilos no dia -07 antes da inoculação com HVE-1 (Quadro 20; Fig. 12). 
Tabela 6 - $\quad$ Contagem diferencial de células alveolares de cavalos do grupo experimental I inoculados com o herpesvírus eqüino tipo 1 (HVE-1). Os resultados foram expressos em média \pm desvio padrão da porcentagem de macrófagos, linfócitos, neutrófilos, eosinófilos e mastócitos, (n=5). São Paulo, 2004

\begin{tabular}{lcccccc}
\hline \multicolumn{7}{c}{ Contagem Diferencial (\%) } \\
\hline Tipo celular & \multicolumn{5}{c}{ Dias pós-inoculação } \\
\cline { 2 - 7 } & -07 & +02 & +09 & +16 & +23 & +30 \\
\hline Macrófagos & $62,1 \pm 23,4$ & $70,0 \pm 26,2$ & $56,0 \pm 14,8$ & $73,6 \pm 11,3$ & $53,9 \pm 11,4$ & $43,4 \pm 13,6$ \\
Linfócitos & $31,3 \pm 20,5$ & $19,8 \pm 13,5$ & $31,1 \pm 12,1$ & $22,7 \pm 9,0$ & $37,5 \pm 12,6$ & $38,8 \pm 16,1$ \\
Neutrófilos & $5,1 \pm 3,3$ & $9,9 \pm 14,8$ & $12,2 \pm 10,7$ & $2,6 \pm 1,9$ & $7,9 \pm 4,0$ & $16,4 \pm 13,0$ \\
Eosinófilos & $1,3 \pm 1,1$ & $0,4 \pm 0,7$ & $0,5 \pm 0,4$ & $0,9 \pm 1,4$ & $0,5 \pm 0,4$ & $0,2 \pm 0,4$ \\
Mastócitos & $0,0 \pm 0,0$ & $0,0 \pm 0,0$ & $0,1 \pm 0,3$ & $0,2 \pm 0,3$ & $0,3 \pm 0,3$ & $1,2 \pm 0,3$ \\
\hline
\end{tabular}

$p<0,05$ Teste ANOVA de Tukey-Kramer

Tabela 7 - $\quad$ Contagem diferencial de células alveolares de cavalos do grupo experimental II inoculados com o herpesvírus eqüino tipo 1 (HVE-1). Os resultados foram expressos em média \pm desvio padrão da porcentagem de macrófagos, linfócitos, neutrófilos, eosinófilos e mastócitos, (n=5). São Paulo, 2004

\begin{tabular}{lcccccc}
\hline \multicolumn{7}{c}{ Contagem Diferencial (\%) } \\
\hline Tipo celular & \multicolumn{5}{c}{ Dias pós-inoculação } \\
\cline { 2 - 7 } & -07 & +02 & +09 & +16 & +23 & +30 \\
\hline Macrófagos & $50,0 \pm 11,9$ & $49,9 \pm 7,1$ & $51,0 \pm 15,6$ & $41,3 \pm 14,9$ & $45,0 \pm 10,5$ & $58,1 \pm 5,3$ \\
Linfócitos & $36,9 \pm 9,6$ & $40,2 \pm 4,6$ & $39,9 \pm 16,4$ & $34,9 \pm 10,7$ & $34,6 \pm 8,2$ & $29,0 \pm 8,4$ \\
Neutrófilos & $9,8 \pm 8,4$ & $8,8 \pm 5,0$ & $8,6 \pm 4,2$ & $22,9 \pm 22,3$ & $18,7 \pm 5,6$ & $10,7 \pm 6,8$ \\
Eosinófilos & $3,2 \pm 7,2$ & $0,6 \pm 1,3$ & $0,4 \pm 0,5$ & $0,8 \pm 0,8$ & $1,5 \pm 1,8$ & $2,2 \pm 3,0$ \\
Mastócitos & $0,1 \pm 0,2$ & $0,4 \pm 0,9$ & $0,1 \pm 0,2$ & $0,1 \pm 0,2$ & $0,1 \pm 0,2$ & $0,1 \pm 0,1$ \\
\hline
\end{tabular}

$\mathrm{p}<0,05$ Teste ANOVA de Tukey-Kramer 
Quadro 17 - Contagem diferencial (\%) dos macrófagos alveolares de cavalos dos grupos experimentais I e II inoculados com o herpesvírus eqüino tipo 1 (HVE-1). São Paulo, 2004

\begin{tabular}{|c|c|c|c|c|c|c|c|c|c|c|}
\hline \multicolumn{11}{|c|}{ Macrófagos Alveolares (\%) } \\
\hline \multirow[b]{2}{*}{$\begin{array}{l}\text { Dias pós- } \\
\text { inoculação }\end{array}$} & \multicolumn{5}{|c|}{ Grupo 1} & \multicolumn{5}{|c|}{ Grupo II } \\
\hline & 01 & 02 & 03 & 04 & 05 & 06 & 07 & 08 & 09 & 10 \\
\hline-07 & 45,7 & 74,3 & 31,3 & 69,0 & 90,0 & 52,0 & 59,0 & 47,5 & 60,5 & 31,0 \\
\hline+02 & 65,0 & 89,7 & 26,3 & 81,7 & 87,3 & 52,0 & 57,0 & 55,5 & 44,0 & 41,0 \\
\hline+09 & 35,3 & 71,7 & 50,7 & 53,7 & 68,7 & 60,5 & 45,5 & 64,0 & 59,0 & 26,0 \\
\hline+16 & 90,0 & 76,0 & 63,0 & 62,7 & 76,3 & 41,5 & $16,0^{\mathrm{M}}$ & 55,0 & 46,5 & 47,5 \\
\hline+23 & 58,3 & 59,3 & 35,3 & 51,3 & 65,0 & 39,5 & 45,0 & 51,5 & 58,0 & 31,0 \\
\hline+30 & 36,3 & 65,3 & 29,3 & 40,7 & 45,3 & 58,7 & 53,7 & 64,4 & 62,0 & 52,0 \\
\hline
\end{tabular}

M: diminuição do número de macrófagos alveolares

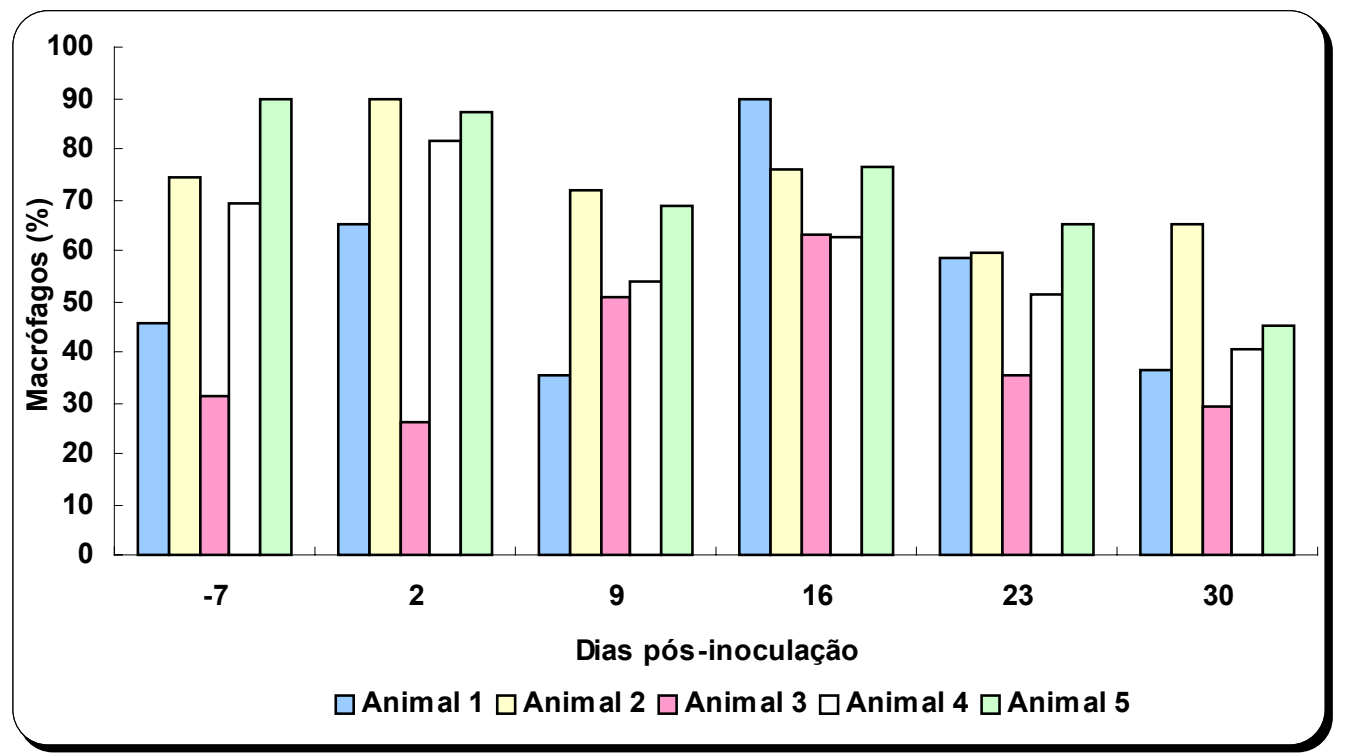

Gráfico 11 - Representação da contagem diferencial (\%) dos macrófagos alveolares de cavalos do grupo experimental I inoculados com o herpesvírus eqüino tipo 1 (HVE-1). São Paulo, 2004 


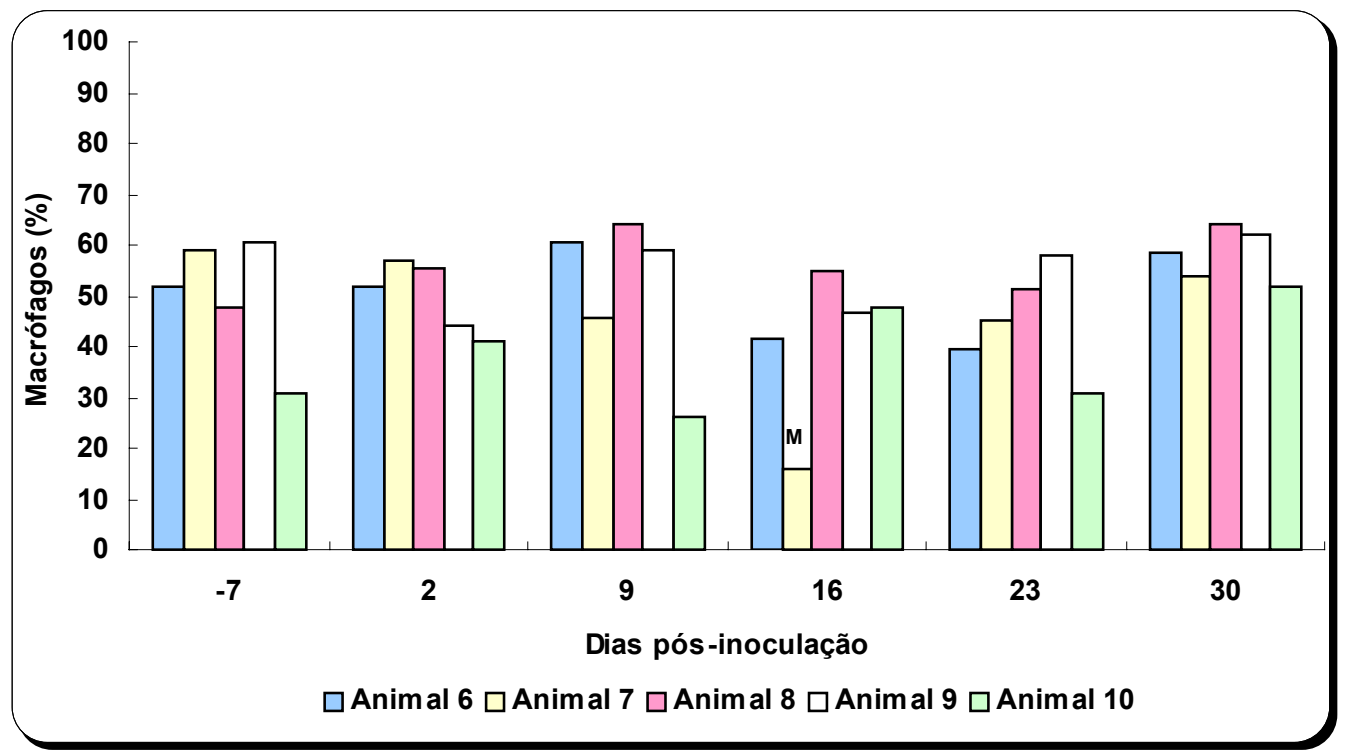

Gráfico 12 - Representação da contagem diferencial (\%) dos macrófagos alveolares de cavalos do grupo experimental II inoculados com o herpesvírus eqüino tipo 1 (HVE-1). São Paulo, 2004

M: diminuição no número de macrófagos alveolares

Quadro 18 - Contagem diferencial (\%) dos linfócitos alveolares de cavalos dos grupos experimentais I e II inoculados com o herpesvírus eqüino tipo 1 (HVE-1). São Paulo, 2004

\begin{tabular}{|c|c|c|c|c|c|c|c|c|c|c|}
\hline \multirow[b]{3}{*}{$\begin{array}{l}\text { Dias pós- } \\
\text { inoculação }\end{array}$} & \multicolumn{9}{|c|}{ Linfócitos Alveolares (\%) } & \\
\hline & \multicolumn{5}{|c|}{ Grupo I } & \multicolumn{5}{|c|}{ Grupo II } \\
\hline & 01 & 02 & 03 & 04 & 05 & 06 & 07 & 08 & 09 & 10 \\
\hline-07 & 43,0 & 17,7 & 60,7 & 25,3 & 10,0 & 38,0 & 40,0 & 31,0 & 25,0 & 50,5 \\
\hline+02 & 32,7 & 9,3 & 36,3 & 9,3 & 11,0 & 36,0 & 42,0 & 35,0 & 46,0 & 42,0 \\
\hline+09 & 48,7 & 24,7 & 18,7 & 38,3 & 25,3 & 33,5 & 52,0 & 23,0 & 29,0 & 62,0 \\
\hline+16 & 9,0 & 20,3 & 31,7 & 30,0 & 22,7 & 30,0 & 24,0 & 28,0 & 48,5 & 44,0 \\
\hline+23 & 34,0 & 34,7 & 59,0 & 34,3 & 25,3 & 32,0 & 40,0 & 28,0 & 27,0 & 46,0 \\
\hline+30 & 50,3 & 30,7 & 54,7 & 43,3 & 15,0 & 33,0 & 40,0 & 24,4 & 29,7 & 18,0 \\
\hline
\end{tabular}


Quadro 19 - Contagem diferencial (\%) dos neutrófilos alveolares de cavalos dos grupos experimentais I e II inoculados com o herpesvírus eqüino tipo 1 (HVE-1). São Paulo, 2004

\begin{tabular}{|c|c|c|c|c|c|c|c|c|c|c|}
\hline \multicolumn{11}{|c|}{ Neutrófilos Alveolares (\%) } \\
\hline \multirow[b]{2}{*}{$\begin{array}{l}\text { Dias pós- } \\
\text { inoculação }\end{array}$} & \multicolumn{5}{|c|}{ Grupo I } & \multicolumn{5}{|c|}{ Grupo II } \\
\hline & 01 & 02 & 03 & 04 & 05 & 06 & 07 & 08 & 09 & 10 \\
\hline-07 & 8,7 & 7,0 & 5,3 & 4,7 & 0,0 & 10,0 & 1,0 & 21,5 & 14,0 & 2,5 \\
\hline+02 & 2,3 & 1,0 & $35,7^{\mathrm{N}}$ & 8,7 & 1,7 & 12,0 & 1,0 & 9,0 & 8,0 & 14,0 \\
\hline+09 & 15,3 & 3,7 & $29,7^{\mathrm{N}}$ & 6,7 & 5,7 & 6,0 & 2,5 & 11,5 & 12,0 & 11,0 \\
\hline+16 & 1,0 & 2,7 & 5,3 & 3,3 & 0,7 & $28,5^{\mathrm{N}}$ & $59,0^{\mathrm{N}}$ & 16,0 & 4,5 & 6,5 \\
\hline+23 & 6,3 & 4,3 & 5,0 & 14,0 & 9,7 & $28,0^{\mathrm{N}}$ & 13,5 & 19,0 & 15,0 & 18,0 \\
\hline+30 & 12,3 & 3,0 & 14,0 & 14,7 & $38,0^{\mathbf{N}}$ & 8,4 & 4,7 & 9,7 & 8,4 & 22,5 \\
\hline
\end{tabular}

$\mathrm{N}$ : neutrofilia

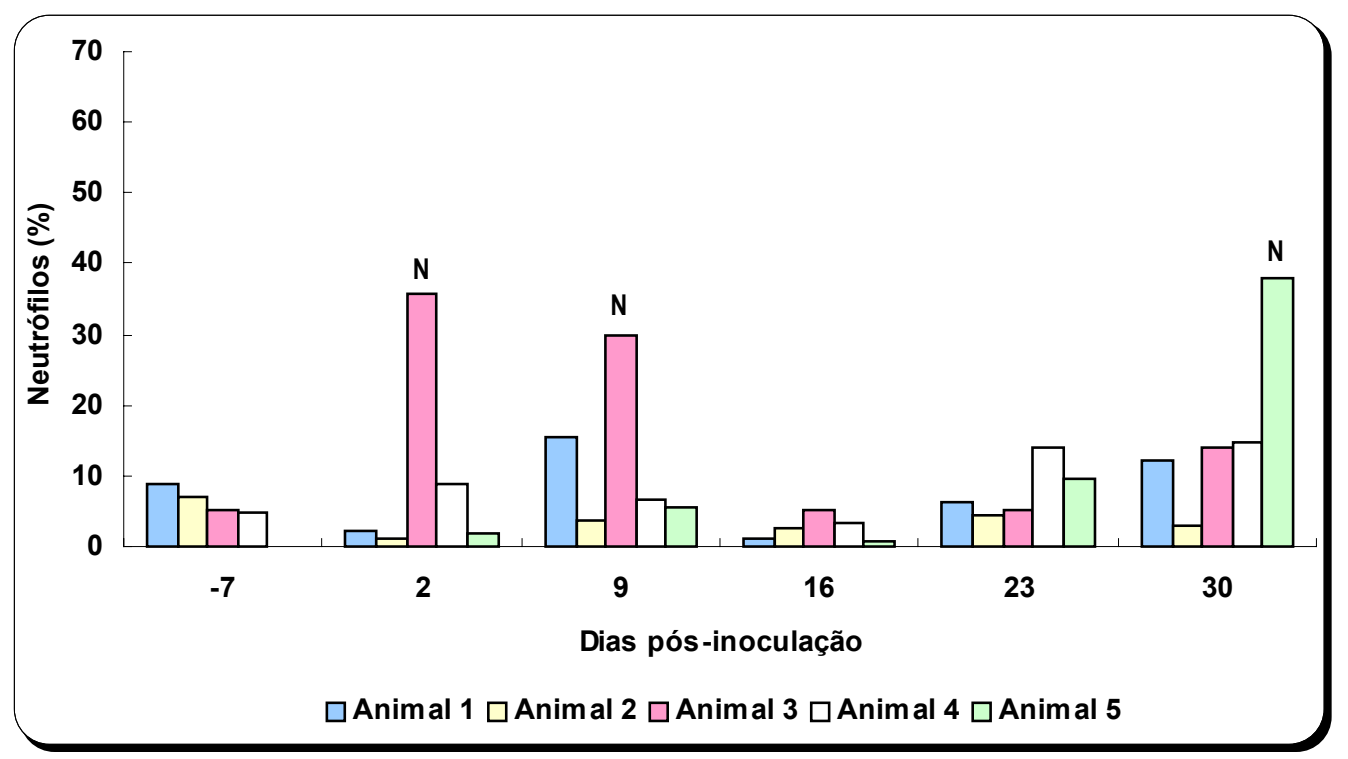

Gráfico 13- Representação da contagem diferencial (\%) dos neutrófilos alveolares de cavalos do grupo experimental I inoculados com o herpesvírus eqüino tipo 1 (HVE-1). São Paulo, 2004

$\mathrm{N}$ : neutrofilia 


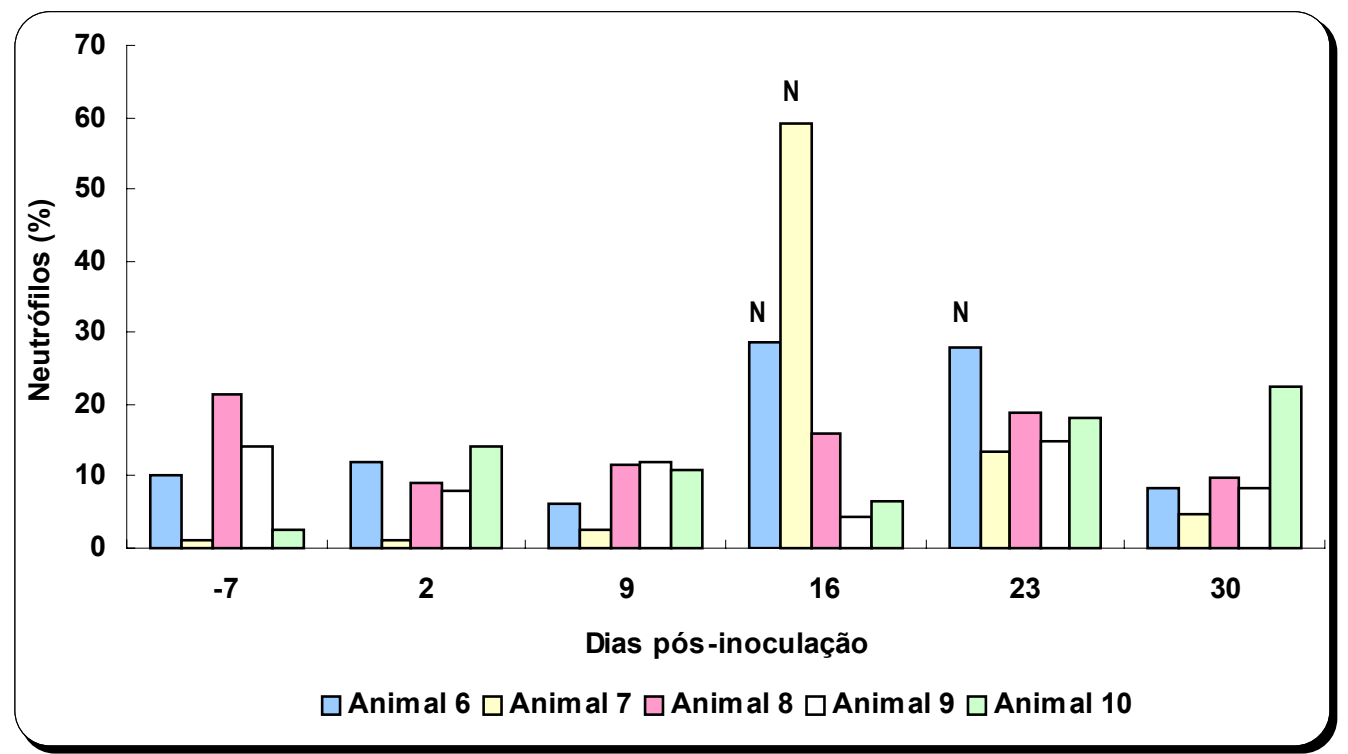

Gráfico 14 - Representação da contagem diferencial (\%) dos neutrófilos alveolares de cavalos do grupo experimental II inoculados com o herpesvírus eqüino tipo 1 (HVE-1). São Paulo, 2004

$\mathrm{N}$ : neutrofilia

Quadro 20 - Contagem diferencial (\%) dos eosinófilos alveolares de cavalos dos grupos experimentais I e II inoculados com o herpesvírus eqüino tipo 1 (HVE-1). São Paulo, 2004

\begin{tabular}{|c|c|c|c|c|c|c|c|c|c|c|}
\hline \multicolumn{11}{|c|}{ Eosinófilos Alveolares (\%) } \\
\hline \multirow[b]{2}{*}{$\begin{array}{l}\text { Dias pós- } \\
\text { inoculação }\end{array}$} & \multicolumn{5}{|c|}{ Grupo I } & \multicolumn{5}{|c|}{ Grupo II } \\
\hline & 01 & 02 & 03 & 04 & 05 & 06 & 07 & 08 & 09 & 10 \\
\hline-07 & 2,7 & 0,7 & 2,0 & 1,0 & 0,0 & 0,0 & 0,0 & 0,0 & 0,0 & 16,0 \\
\hline+02 & 0,0 & 0,0 & 1,7 & 0,3 & 0,0 & 0,0 & 0,0 & 0,0 & 0,0 & 3,0 \\
\hline+09 & 0,7 & 0,0 & 1,0 & 0,7 & 0,3 & 0,0 & 0,0 & 1,0 & 0,0 & 1,0 \\
\hline+16 & 0,0 & 1,0 & 0,0 & 3,3 & 0,0 & 0,0 & 1,0 & 1,0 & 0,0 & 2,0 \\
\hline+23 & 0,7 & 1,0 & 0,3 & 0,3 & 0,0 & 0,0 & 1,5 & 1,5 & 0,0 & 4,5 \\
\hline+30 & 0,0 & 0,0 & 1,0 & 0,0 & 0,0 & 0,7 & 1,3 & 1,3 & 0,0 & 7,5 \\
\hline
\end{tabular}


Quadro 21 - Contagem diferencial (\%) dos mastócitos alveolares de cavalos dos grupos experimentais I e II inoculados com o herpesvírus eqüino tipo 1 (HVE-1). São Paulo, 2004

\begin{tabular}{|c|c|c|c|c|c|c|c|c|c|c|}
\hline \multicolumn{11}{|c|}{ Mastócitos Alveolares (\%) } \\
\hline \multirow[b]{2}{*}{$\begin{array}{l}\text { Dias pós- } \\
\text { inoculação }\end{array}$} & \multicolumn{5}{|c|}{ Grupo I } & \multicolumn{5}{|c|}{ Grupo II } \\
\hline & 01 & 02 & 03 & 04 & 05 & 06 & 07 & 08 & 09 & 10 \\
\hline-07 & 0,0 & 0,0 & 0,0 & 0,0 & 0,0 & 0,0 & 0,0 & 0,0 & 0,5 & 0,0 \\
\hline+02 & 0,0 & 0,0 & 0,0 & 0,0 & 0,0 & 0,0 & 0,0 & 0,0 & 2,0 & 0,0 \\
\hline+09 & 0,0 & 0,0 & 0,0 & 0,7 & 0,0 & 0,0 & 0,0 & 0,5 & 0,0 & 0,0 \\
\hline+16 & 0,0 & 0,0 & 0,0 & 0,7 & 0,3 & 0,0 & 0,0 & 0,0 & 0,5 & 0,0 \\
\hline+23 & 0,7 & 0,7 & 0,3 & 0,0 & 0,0 & 0,5 & 0,0 & 0,0 & 0,0 & 0,0 \\
\hline+30 & 1,0 & 1,0 & 1,0 & 1,3 & 1,7 & 0,0 & 0,3 & 0,0 & 0,0 & 0,0 \\
\hline
\end{tabular}

Figura 6 - Fotomicrografia de células do lavado broncoalveolar de cavalo. Em destaque: macrófagos inativos. Coloração de Rosenfeld. Microscopia óptica de imersão, aumento $1000 \times$ 


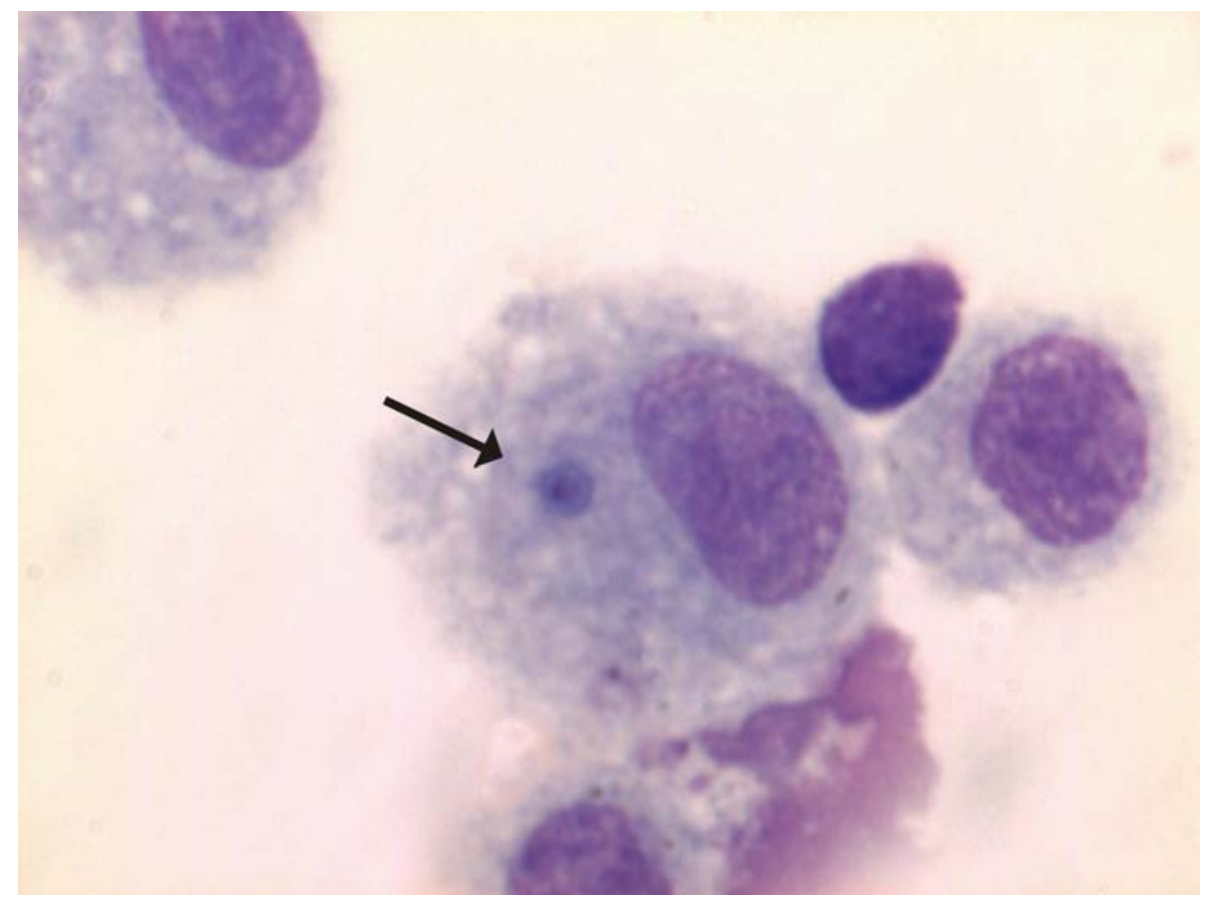

Figura 7 - Fotomicrografia de células do lavado broncoalveolar de cavalo. Em destaque: macrófago contendo partícula fagocitada no interior do citoplasma. Coloração de Rosenfeld. Microscopia óptica de imersão, aumento 1000×

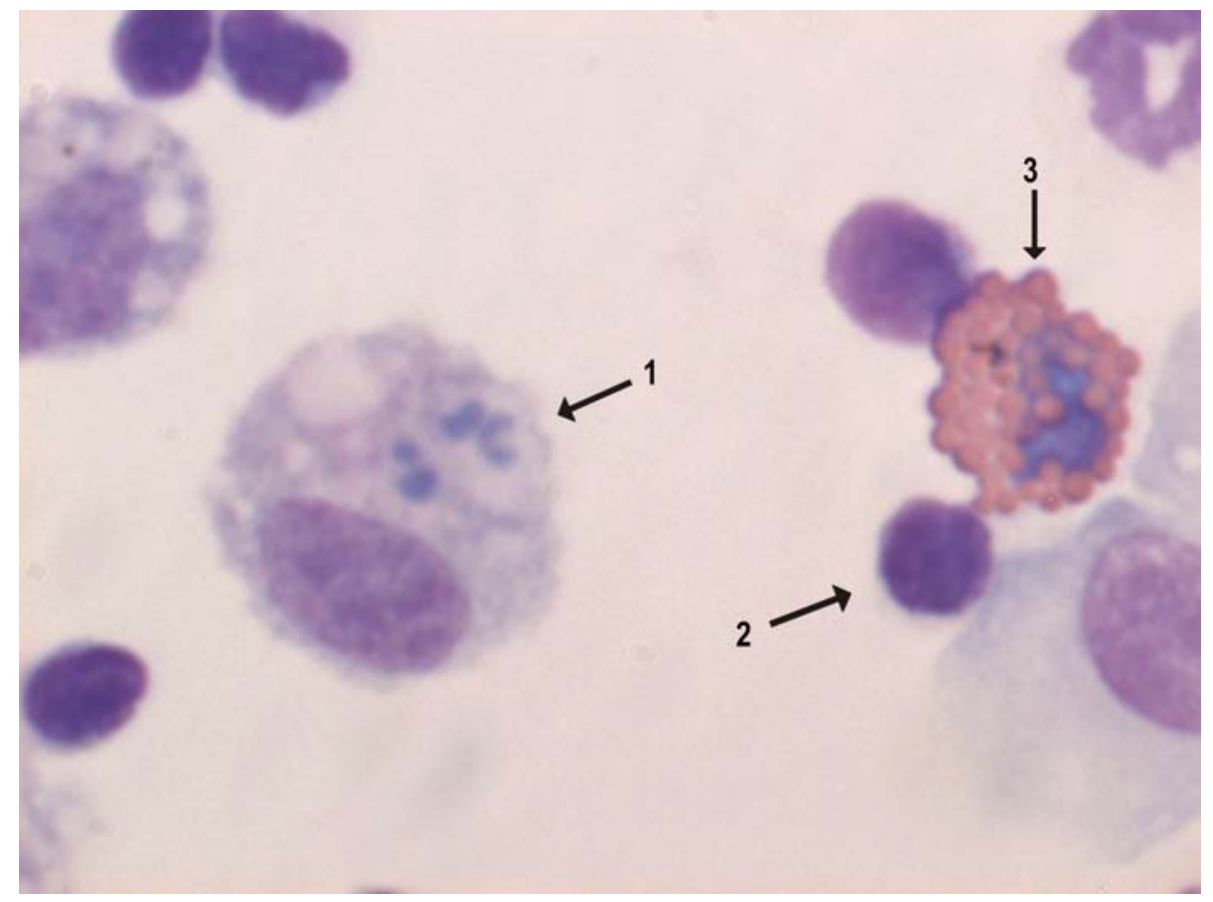

Figura 8 - Fotomicrografia de células do lavado broncoalveolar de cavalo. Em destaque: 1. macrófago contendo neutrófilo fagocitado no interior do citoplasma; 2. linfócito; 3. eosinófilo. Coloração de Rosenfeld. Microscopia óptica de imersão, aumento $1000 \times$ 


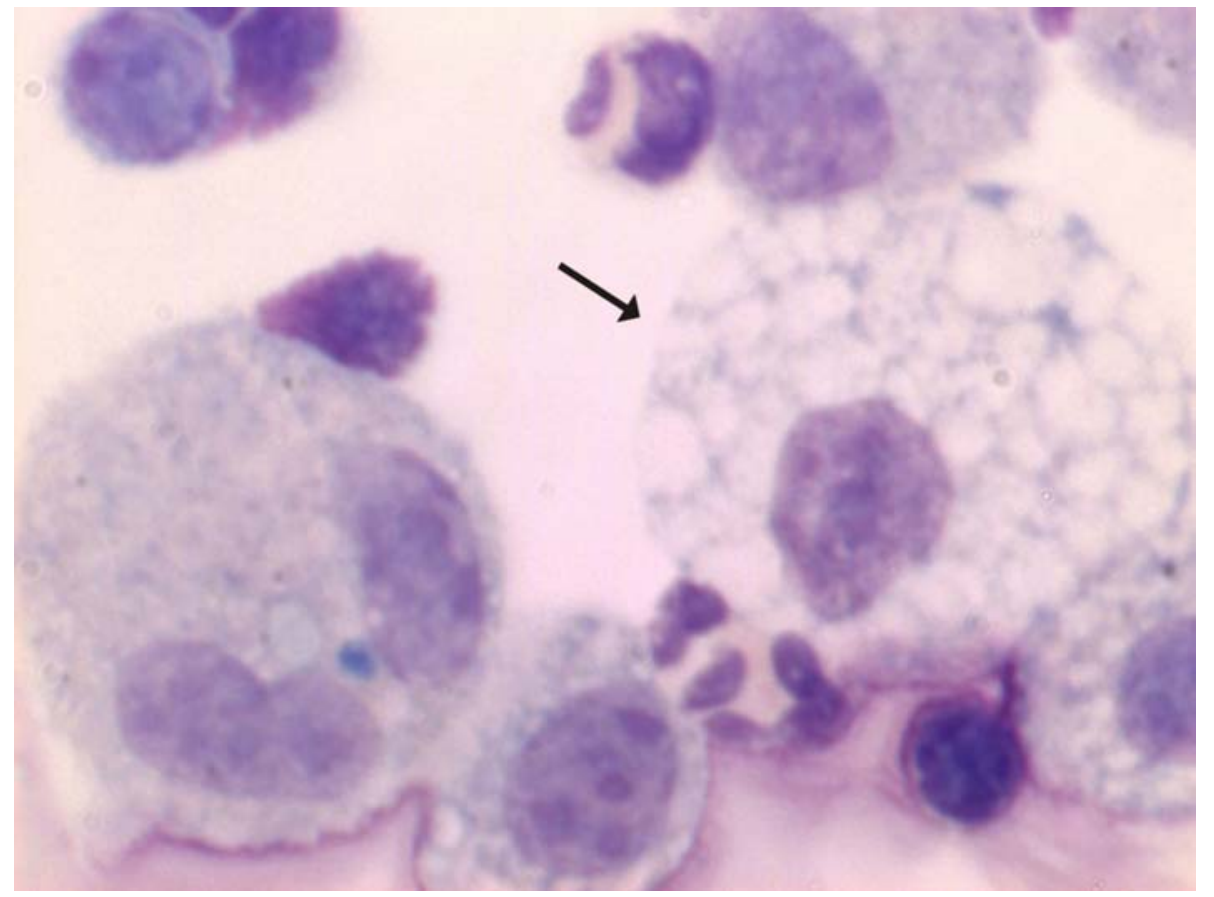

Figura 9 - Fotomicrografia de células do lavado broncoalveolar de cavalo. Em destaque: macrófago espumoso. Coloração de Rosenfeld. Microscopia óptica de imersão, aumento $1000 \times$

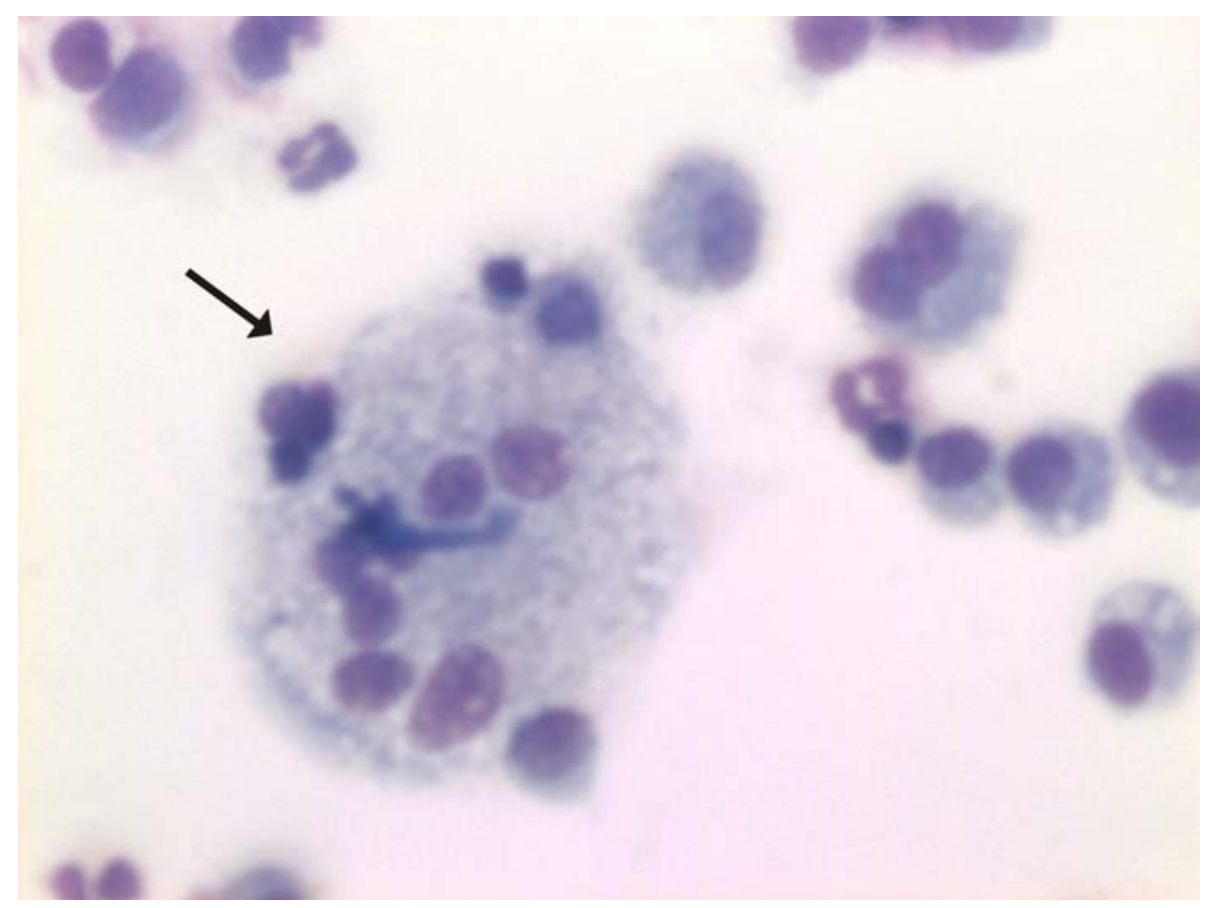

Figura 10 - Fotomicrografia de células do lavado broncoalveolar de cavalo. Em destaque: célula gigante multinucleada. Coloração de Rosenfeld. Microscopia óptica, aumento $400 \times$ 


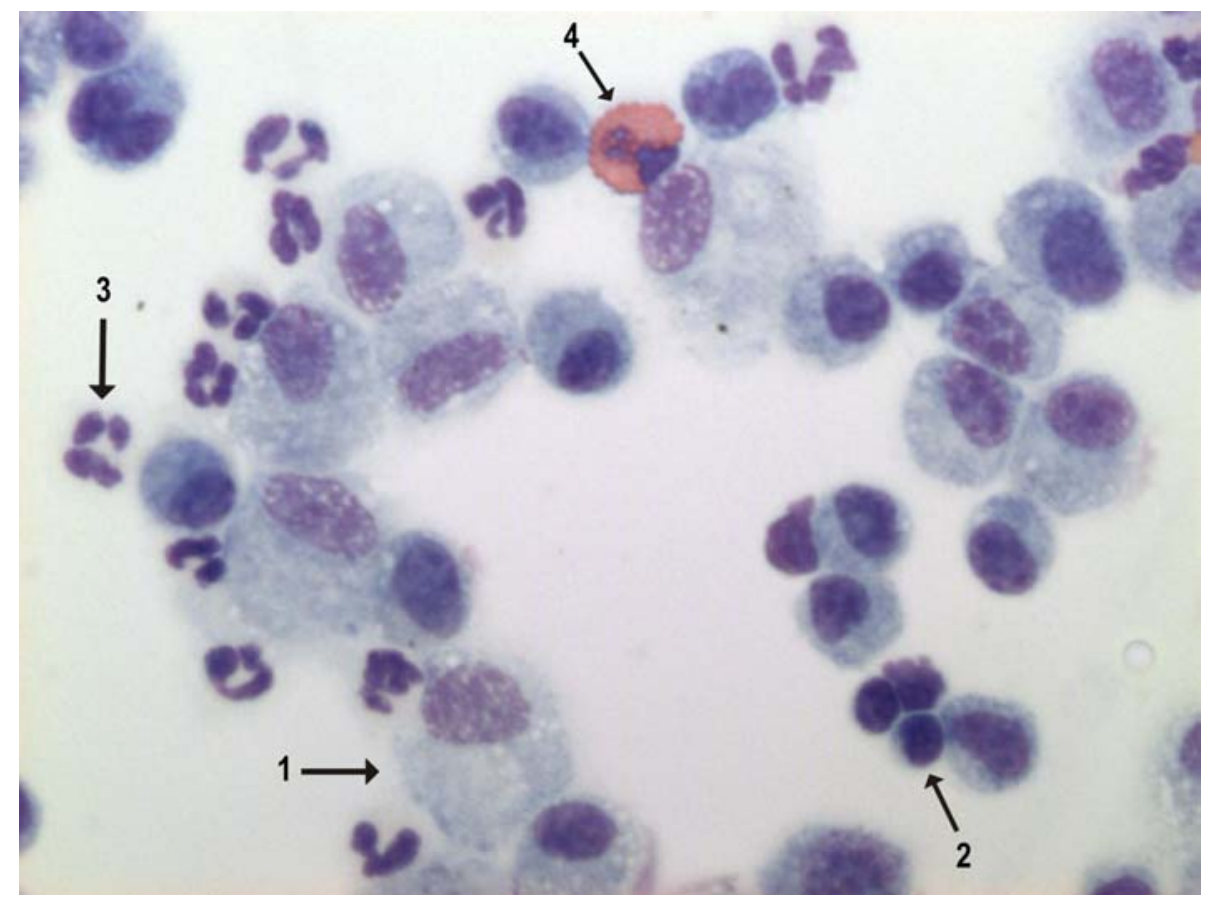

Figura 11 - Fotomicrografia de células do lavado broncoalveolar de cavalo. Em destaque: 1. macrófago; 2. linfócito; 3. neutrófilo; 4. eosinófilo. Coloração de Rosenfeld. Microscopia óptica, aumento $400 \times$

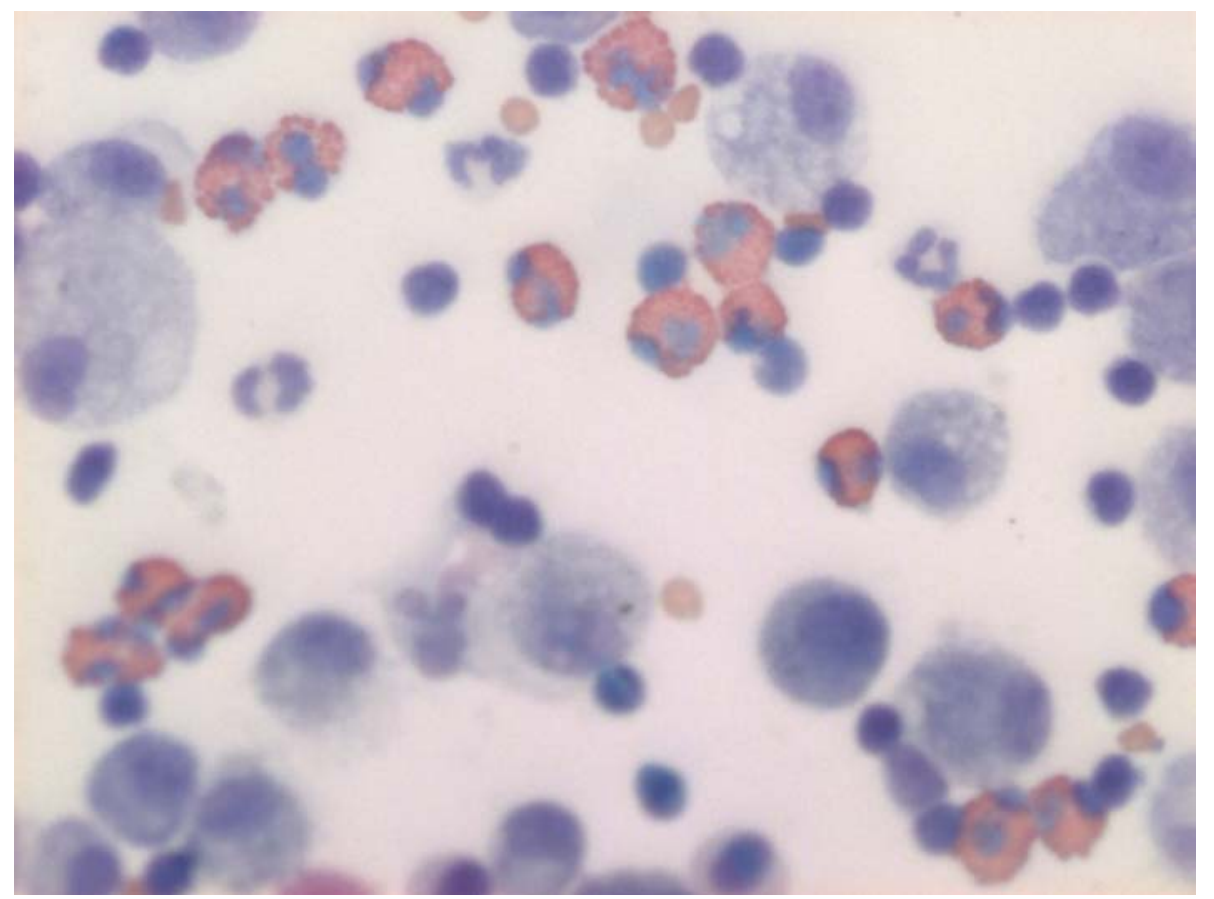

Figura 12 - Fotomicrografia de células do lavado broncoalveolar de cavalo. Em destaque: presença de grande número de eosinófilos. Coloração de Rosenfeld. Microscopia óptica, aumento 400x 


\subsection{DETECÇÃo do DNA VIRAL PELA ELETROFORESE dos PRODUTOS DA PCR}

O controle positivo derivado da estirpe viral Army 183 do HVE-1 foi consistentemente amplificado, produzindo bandas de tamanho esperado de $226 \mathrm{pb}$, utilizando pares específicos de primers para a região do gene do HVE-1 que codifica a timidina quinase (tk). Já os outros dois controles positivos - a amostra padrão A4/72 do HVE-1 e a vacina Equibort ${ }^{\circledR}$ Biovet -, não foram amplificados na mesma reação (Fig. 13).

A detecção do DNA viral nas amostras de LBA e de sangue dos cavalos dos grupos experimentais I e II, utilizando os pares específicos de primers tkF1/R2 e tkF3/R2, apresentou resultados positivos, de forma dispersa, conforme pode ser observado nos quadros 22 e 23 .

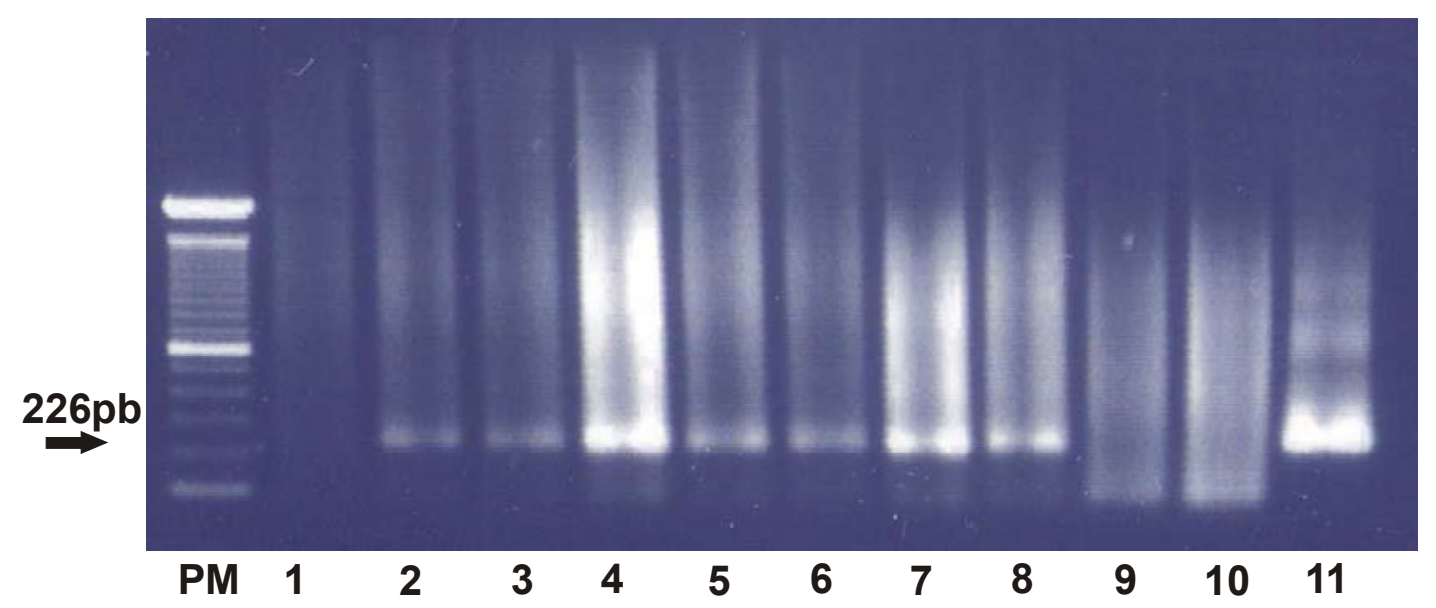

Figura 13 - Eletroforese em gel de agarose a 1,5\% corado com brometo de etídio. Produtos amplificados com tamanho de $226 \mathrm{pb}$ obtidos com oligonucleotídeos iniciadores (primers) para a região do gene do herpesvírus eqüino tipo 1 (HVE-1) que codifica a timidina quinase (tk). PM: padrão de peso molecular de 100pb. 1: controle negativo. 2 a 4: amostras positivas do sangue de cavalos. 5 a 8: amostras positivas de lavado broncoalveolar (LBA) de cavalos. 9: vacina Equibort ${ }^{\circledR}$ Biovet. 10: amostra padrão A4/72. 11: vacina derivada da estirpe viral Army 183 
Quadro 22 - Detecção do herpesvírus eqüino tipo 1 (HVE-1) proveniente de amostras do lavado broncoalveolar (LBA) de cavalos pela reação em cadeia pela polimerase (PCR), utilizando oligonucleotídeos iniciadores (primers) para a região do gene que codifica a timidina quinase (tk). São Paulo, 2004

\begin{tabular}{ccccccc}
\hline & \multicolumn{7}{c}{ PCR } \\
\cline { 2 - 7 } Animal & \multicolumn{7}{c}{ Dias pós-inoculação } \\
\cline { 2 - 7 } & -07 & +02 & +09 & +16 & +23 & +30 \\
\hline 01 & - & - & - & - & - & + \\
02 & - & - & + & - & + & + \\
03 & - & - & - & - & - & - \\
04 & - & - & + & - & - & - \\
05 & - & - & - & - & - & - \\
06 & - & - & - & - & - & + \\
07 & - & - & - & - & + & - \\
08 & - & - & - & - & - & - \\
09 & - & - & - & + & - & - \\
10 & - & - & - & - & - & $3 / 10$ \\
\hline Total & $0 / 10$ & $0 / 10$ & $2 / 10$ & $1 / 10$ & $2 / 10$ & \\
\hline
\end{tabular}

+: positivo.-: negativo 
Quadro 23 - Detecção do herpesvírus eqüino tipo 1 (HVE-1) proveniente de amostras de sangue de cavalos pela reação em cadeia pela polimerase (PCR), utilizando oligonucleotídeos iniciadores (primers) para a região do gene que codifica a timidina quinase (tk). São Paulo, 2004

\begin{tabular}{|c|c|c|c|c|c|c|c|c|c|c|c|c|c|c|}
\hline \multirow{3}{*}{ Animal } & \multicolumn{14}{|c|}{ PCR } \\
\hline & \multicolumn{14}{|c|}{ Dias pós-inoculação } \\
\hline & 0 & 01 & 02 & 03 & 04 & 05 & 06 & 07 & 08 & 09 & 10 & 16 & 23 & 30 \\
\hline 01 & - & - & + & - & - & - & - & + & - & - & - & - & + & - \\
\hline 02 & - & - & - & - & - & - & - & - & - & - & - & - & - & - \\
\hline 03 & - & + & - & - & - & + & + & - & - & - & - & - & - & - \\
\hline 04 & + & - & - & - & - & - & - & - & - & - & - & - & - & - \\
\hline 05 & - & - & - & - & - & - & - & - & - & - & + & - & - & - \\
\hline 06 & + & - & - & - & - & + & - & - & - & - & - & + & - & - \\
\hline 07 & - & - & - & - & - & - & + & - & - & - & - & - & - & + \\
\hline 08 & - & + & - & - & - & - & - & - & - & + & - & - & - & - \\
\hline 09 & - & + & - & - & - & - & - & - & - & - & - & + & - & - \\
\hline 10 & - & - & - & - & - & - & - & - & - & - & + & + & - & - \\
\hline Total & $2 / 10$ & $3 / 10$ & $1 / 10$ & $0 / 10$ & $0 / 10$ & $2 / 10$ & $2 / 10$ & $1 / 10$ & $0 / 10$ & $1 / 10$ & $2 / 10$ & $3 / 10$ & $1 / 10$ & $1 / 10$ \\
\hline
\end{tabular}

+: positivo. -: negativo

Todos os controles positivos - estirpe viral Army 183 do HVE-1, amostra padrão A4/72 do HVE-1 e vacina Equibort ${ }^{\circledR}$ Biovet - foram consistentemente amplificados, produzindo bandas de tamanho esperado de $460 \mathrm{pb}$, utilizando os pares específicos de primers para a região do gene do HVE-1 que codifica a glicopropteína B (gB) (Fig. 14 e 15).

No grupo experimental I, os pares de primers FC2/RC e FC2/R1 detectaram a presença de DNA viral no LBA do animal 04 no nono d.p.i., e do animal 02 no nono, décimo-sexto e trigésimo d.p.i. (Quadro 24). Nas amostras de LBA dos cavalos do grupo experimental II detectou-se PCR positiva a partir do nono d.p.i., e todos os animais tornaram-se positivos nos dias +23 e +30 pós-inoculação. A única exceção 
foi o animal 07 , no qual detectou-se PCR positiva para o HVE-1 a partir do segundo d.p.i. (Quadro 24).

$\mathrm{Na}$ detecção do DNA viral das amostras de sangue dos animais dos grupos experimentais I e II utilizando os mesmos pares de primers, a maioria dos resultados positivos concentraram-se entre os dias +03 e +08 pós-inoculação, conforme observado no Quadro 25.

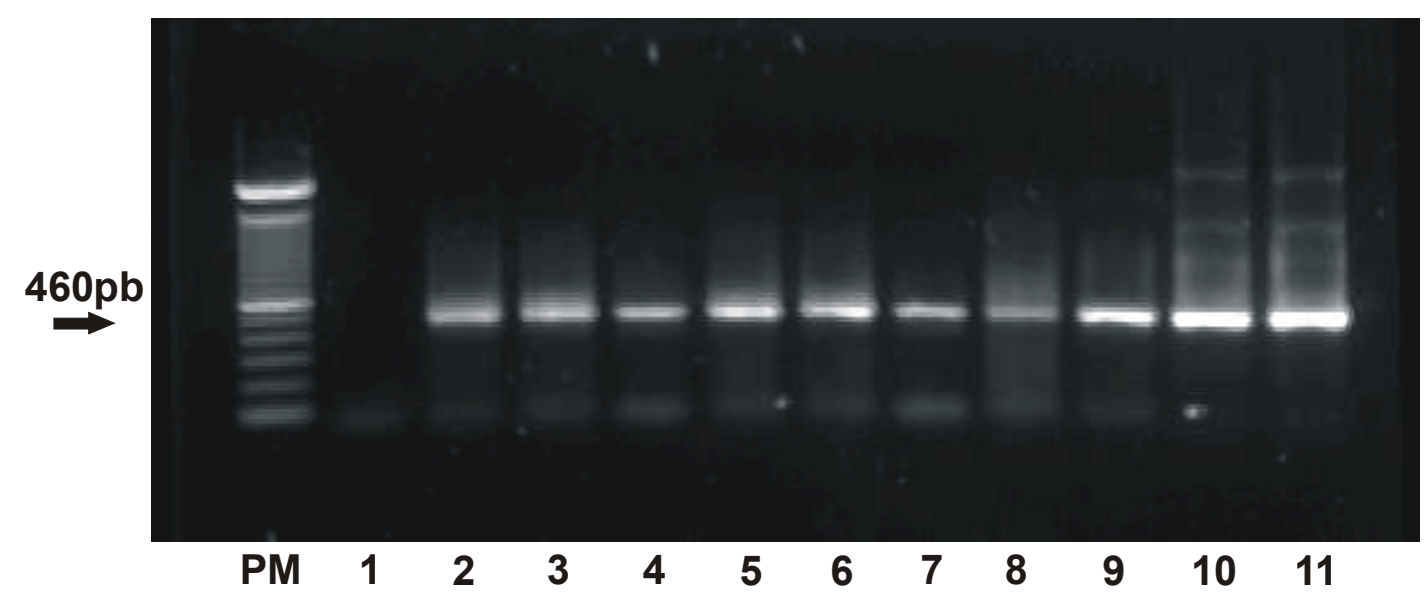

Figura 14 - Eletroforese em gel de agarose a 1,5\% corado com brometo de etídio. Produtos amplificados com tamanho de $460 \mathrm{pb}$ obtidos com oligonucleotídeos iniciadores (primers) para a região do gene do herpesvírus eqüino tipo 1 (HVE-1) que codifica a glicoproteína B (gB). PM: padrão de peso molecular de 100pb. 1: controle negativo. 2 a 4: amostras positivas do sangue de cavalos. 5 a 8: amostras positivas de lavado broncoalveolar (LBA) de cavalos. 9: vacina Equibort ${ }^{\circledR}$ Biovet. 10: amostra padrão A4/72. 11: vacina derivada da estirpe viral Army 183 


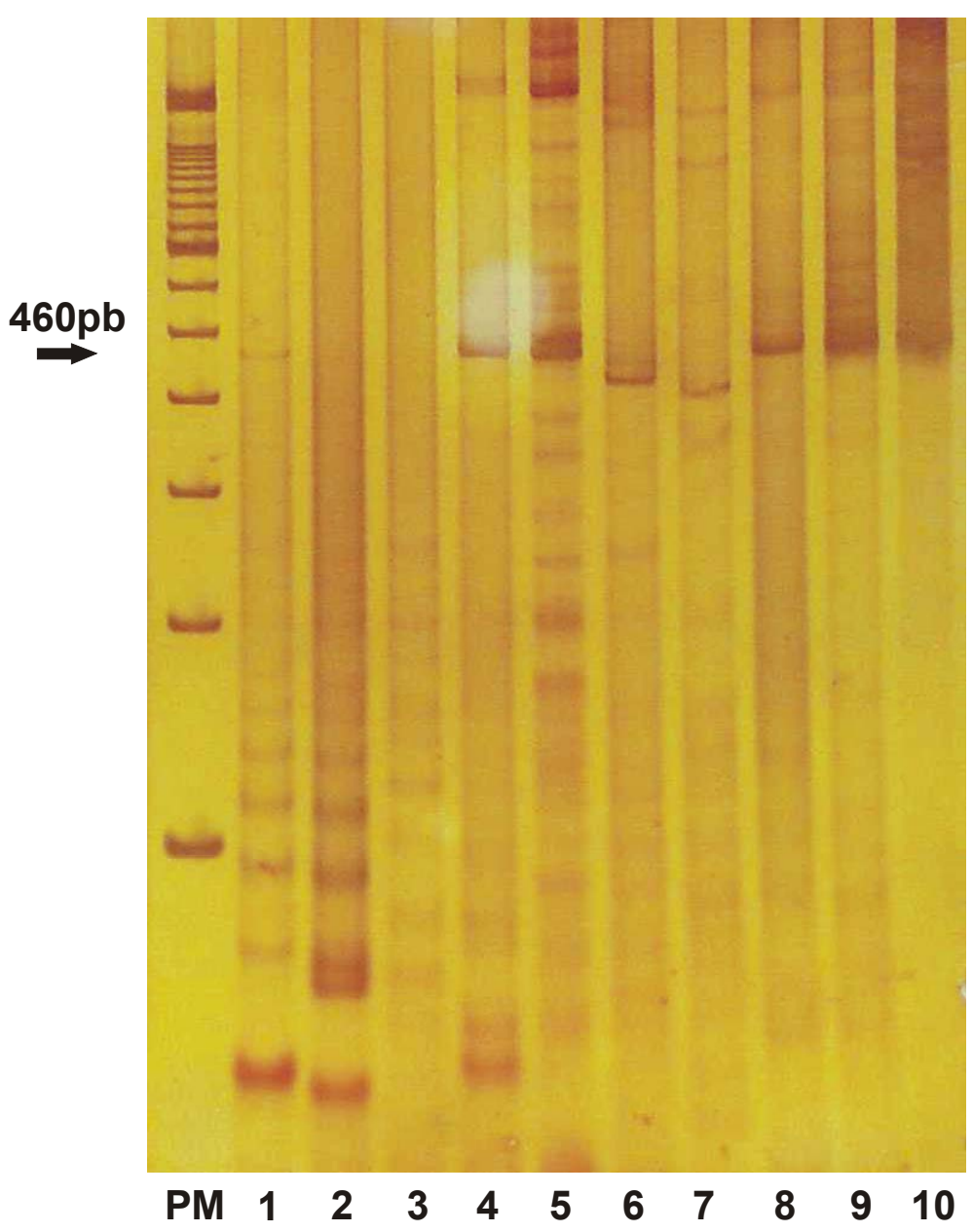

Figura 15 - Eletroforese em gel de poliacrilamida a $8 \%$ corado com nitrato de prata. Produtos amplificados com tamanho de $460 \mathrm{pb}$ obtidos com oligonucleotídeos iniciadores (primers) para a região do gene do herpesvírus eqüino tipo 1 (HVE-1) que codifica a glicoproteína B (gB). PM: padrão de peso molecular de 100pb. 1: amostra "fracamente" positiva de lavado broncoalveolar (LBA) de cavalo. 2: amostra negativa de LBA de cavalo. 3: controle negativo. 4 e 5: amostras positivas de sangue de cavalo. 6 e 7: amostras negativas (reações inespecíficas) de sangue de cavalo. 8: vacina Equibort ${ }^{\circledR}$ Biovet. 9: amostra padrão A4/72. 10: vacina derivada da estirpe viral Army 183 
Quadro 24 - Detecção do herpesvírus eqüino tipo 1 (HVE-1) proveniente de amostras do lavado broncoalveolar (LBA) de cavalos pela reação em cadeia pela polimerase (PCR), utilizando oligonucleotídeos iniciadores (primers) para a região do gene que codifica a glicoproteína B (gB). São Paulo, 2004

\begin{tabular}{ccccccc}
\hline & \multicolumn{7}{c}{ PCR } \\
\cline { 2 - 7 } Animal & \multicolumn{7}{c}{ Dias pós-inoculação } \\
\cline { 2 - 7 } & -07 & +02 & +09 & +16 & +23 & +30 \\
\hline 01 & - & - & - & - & - & - \\
02 & - & - & + & + & - & + \\
03 & - & - & - & - & - & - \\
04 & - & - & + & - & - & - \\
05 & - & - & - & - & - & - \\
06 & - & - & + & + & + & + \\
07 & - & + & + & + & + & + \\
08 & - & - & - & - & + & + \\
09 & - & - & + & + & + & + \\
10 & - & - & + & + & + & + \\
\hline Total & $0 / 10$ & $1 / 10$ & $6 / 10$ & $5 / 10$ & $5 / 10$ & $6 / 10$ \\
\hline
\end{tabular}

+: positivo. -: negativo 
Quadro 25 - Detecção do herpesvírus eqüino tipo 1 (HVE-1) proveniente de amostras de sangue de cavalos pela reação em cadeia pela polimerase (PCR), utilizando oligonucleotídeos iniciadores (primers) para a região do gene que codifica a glicoproteína B (gB). São Paulo, 2004

\begin{tabular}{|c|c|c|c|c|c|c|c|c|c|c|c|c|c|c|}
\hline \multirow{3}{*}{ Animal } & \multicolumn{14}{|c|}{ PCR } \\
\hline & \multicolumn{14}{|c|}{ Dias pós-inoculação } \\
\hline & 0 & 01 & 02 & 03 & 04 & 05 & 06 & 07 & 08 & 09 & 10 & 16 & 23 & 30 \\
\hline 01 & - & - & + & + & + & + & + & + & + & - & - & - & - & - \\
\hline 02 & - & - & + & + & - & + & + & + & + & - & - & - & - & - \\
\hline 03 & + & + & + & - & + & + & + & + & + & - & - & - & - & - \\
\hline 04 & + & + & - & + & + & + & + & + & - & - & - & - & - & - \\
\hline 05 & - & + & - & + & - & + & + & + & - & - & + & - & - & - \\
\hline 06 & + & - & - & - & + & + & + & + & + & + & + & + & - & - \\
\hline 07 & - & - & - & + & + & + & + & + & + & - & - & - & - & + \\
\hline 08 & - & - & - & + & - & + & - & + & + & + & + & - & - & - \\
\hline 09 & - & - & - & + & + & + & + & + & - & + & - & + & - & - \\
\hline 10 & - & - & - & - & + & + & - & + & + & + & - & + & - & - \\
\hline Total & $3 / 10$ & $3 / 10$ & $3 / 10$ & $7 / 10$ & $7 / 10$ & $10 / 10$ & $8 / 10$ & $10 / 10$ & $7 / 10$ & $4 / 10$ & $3 / 10$ & $3 / 10$ & $0 / 10$ & $1 / 10$ \\
\hline
\end{tabular}

+: positivo. -: negativo 


\subsection{INFECÇÃo EXPERIMENTAL PELO HVE-1 em CAMUNDONgos}

\subsubsection{EXAME Físıco}

A partir do segundo d.p.i. os camundongos inoculados com HVE-1 apresentaram conjuntivite bilateral muco-purulenta, pelame áspero, sem brilho e eriçado, desidratação, apatia, arqueamento de dorso, taquipnéia e dispnéia (Fig. 16, 17 e 18). Nesse dia um animal foi sacrificado para colheita dos órgãos internos.

No terceiro d.p.i., seis animais apresentaram piora no quadro clínico anteriormente mencionado, com tetraparesia, diminuição na propriocepção, decúbito lateral e hiperexcitabilidade demonstrada por seguidos episódios convulsivos (Fig. 19 e 20). Esses animais foram submetidos à eutanásia para colheita de material. Somente um animal do grupo experimental sobreviveu e não apresentou manifestações clínicas, sendo sacrificado no quadragésimo segundo d.p.i.

Os sete camundongos que desenvolveram manifestações clínicas apresentaram menor desenvolvimento corpóreo do que aqueles do grupo controle. No segundo e terceiro d.p.i. observou-se diferença significativa de peso corpóreo entre os camundongos dos grupos controle e experimental (Tab. 8). 
Tabela 8 - $\quad$ Peso corpóreo (g) de camundongos dos grupos controle e experimental (inoculados com o herpesvírus eqüino tipo 1). Os resultados foram expressos em média \pm desvio padrão. São Paulo, 2004

\begin{tabular}{|c|c|c|}
\hline Dias pós-inoculação & Controle & Experimental \\
\hline 0 & $\begin{array}{c}18,67 \pm 1,79 \\
(n=4)\end{array}$ & $\begin{array}{c}18,12 \pm 1,79 \\
(n=8)\end{array}$ \\
\hline 01 & $\begin{array}{c}19,58 \pm 1,76 \\
(n=4)\end{array}$ & $\begin{array}{c}18,79 \pm 1,68 \\
(n=8)\end{array}$ \\
\hline 02 & $\begin{array}{c}20,00 \pm 1,82^{a} \\
(n=4)\end{array}$ & $\begin{array}{c}18,03 \pm 1,74^{b} \\
(n=7)\end{array}$ \\
\hline 03 & $\begin{array}{c}20,78 \pm 2,01^{a} \\
(n=4)\end{array}$ & $\begin{array}{c}15,81 \pm 3,03^{b} \\
(n=7)\end{array}$ \\
\hline 04 & $\begin{array}{c}21,13 \pm 1,99 \\
(n=4)\end{array}$ & $\begin{array}{l}22,16 \\
(n=1)\end{array}$ \\
\hline 05 & $\begin{array}{c}21,40 \pm 2,24 \\
(n=4)\end{array}$ & $\begin{array}{l}22,30 \\
(n=1)\end{array}$ \\
\hline 06 & $\begin{array}{c}21,25 \pm 1,83 \\
(n=4)\end{array}$ & $\begin{array}{l}22,80 \\
(n=1)\end{array}$ \\
\hline 07 & $\begin{array}{c}21,58 \pm 1,93 \\
(n=4)\end{array}$ & $\begin{array}{l}22,70 \\
(n=1)\end{array}$ \\
\hline 08 & $\begin{array}{c}21,80 \pm 1,75 \\
(n=4)\end{array}$ & $\begin{array}{l}21,70 \\
(n=1)\end{array}$ \\
\hline 09 & $\begin{array}{c}21,08 \pm 1,64 \\
(n=4)\end{array}$ & $\begin{array}{l}21,80 \\
(n=1)\end{array}$ \\
\hline
\end{tabular}

Letras diferentes na mesma linha expressam diferenças significativas. $p<0,05$ Teste t de student. 


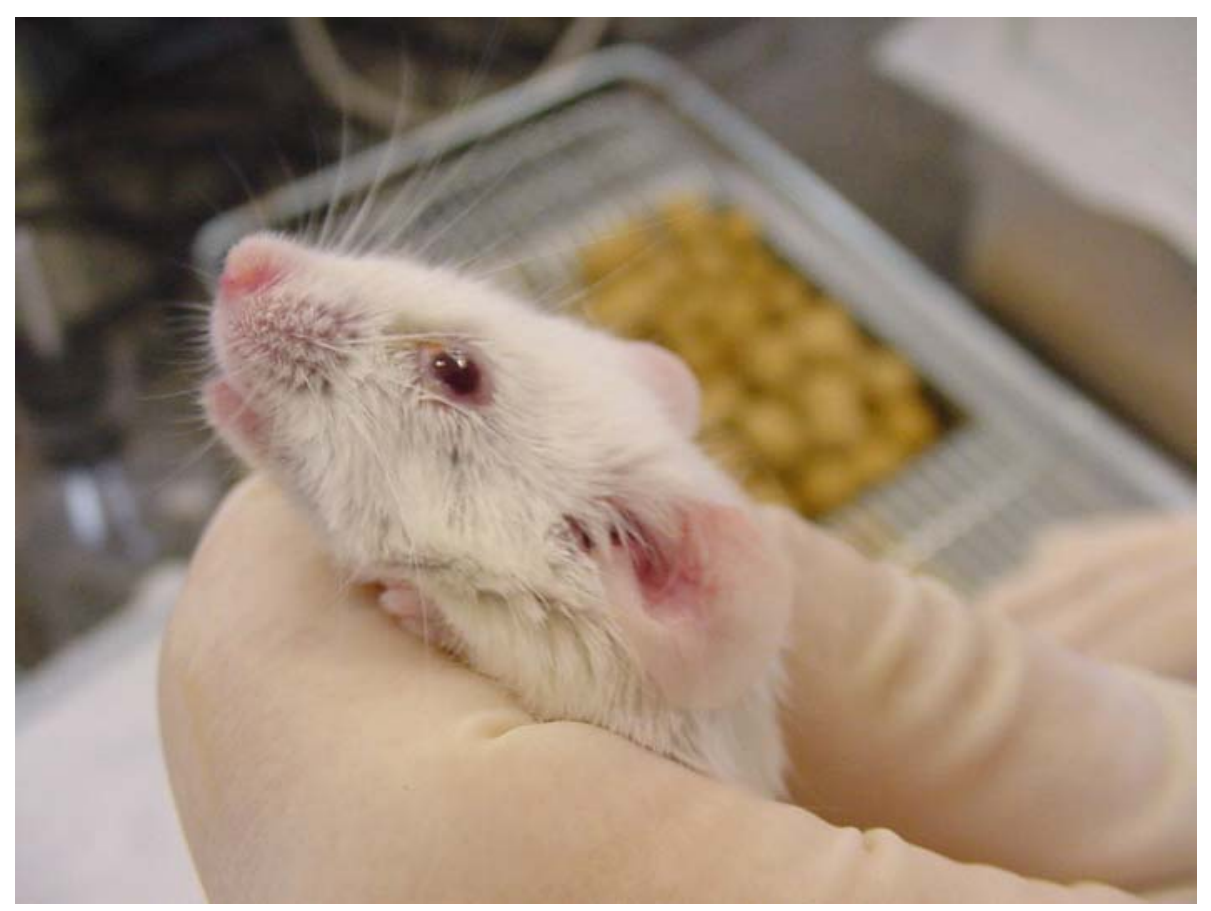

Figura 16 - Camundongo inoculado com o herpesvírus eqüino tipo 1 (HVE-1) apresentando conjuntivite mucopurulenta

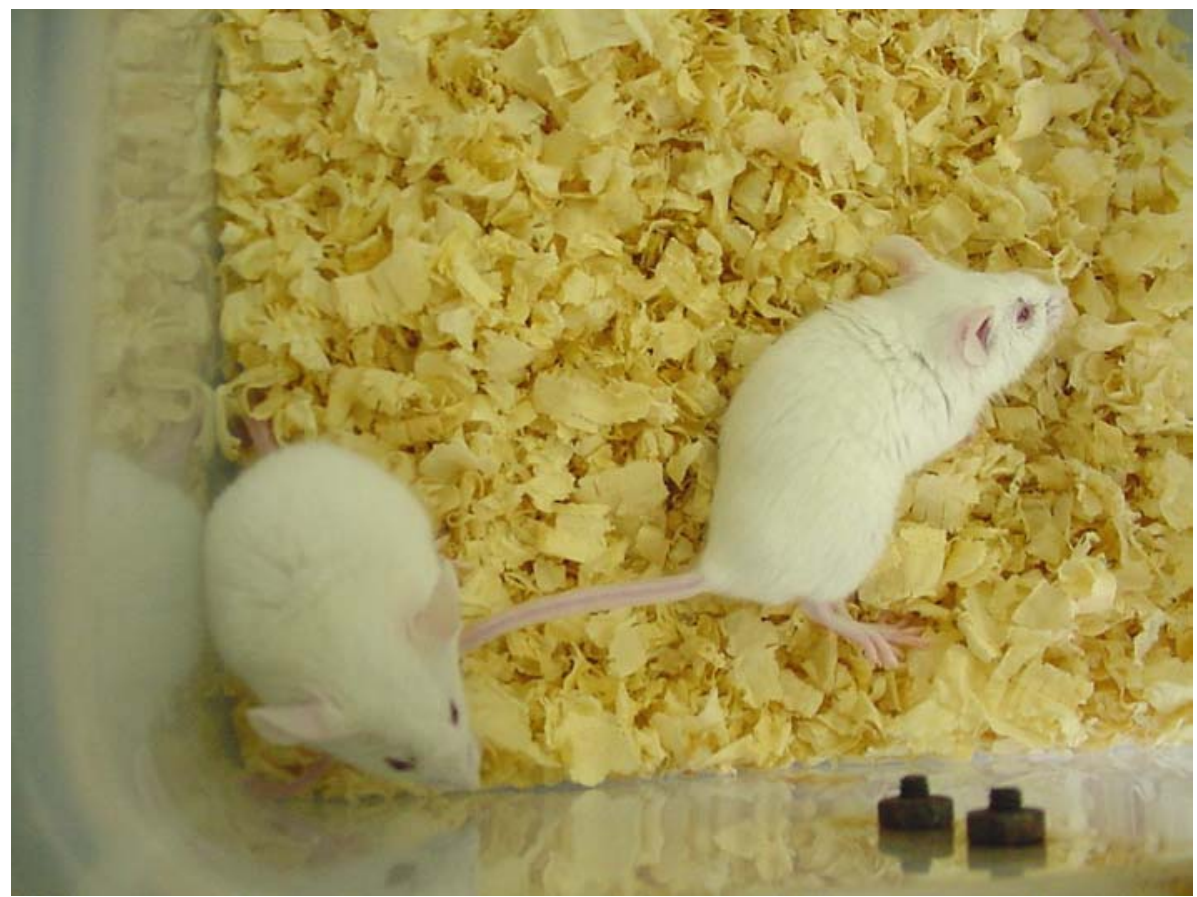

Figura 17 - Camundongos inoculados com o herpesvírus eqüino tipo 1 (HVE-1) apresentando apatia e arqueamento do dorso 


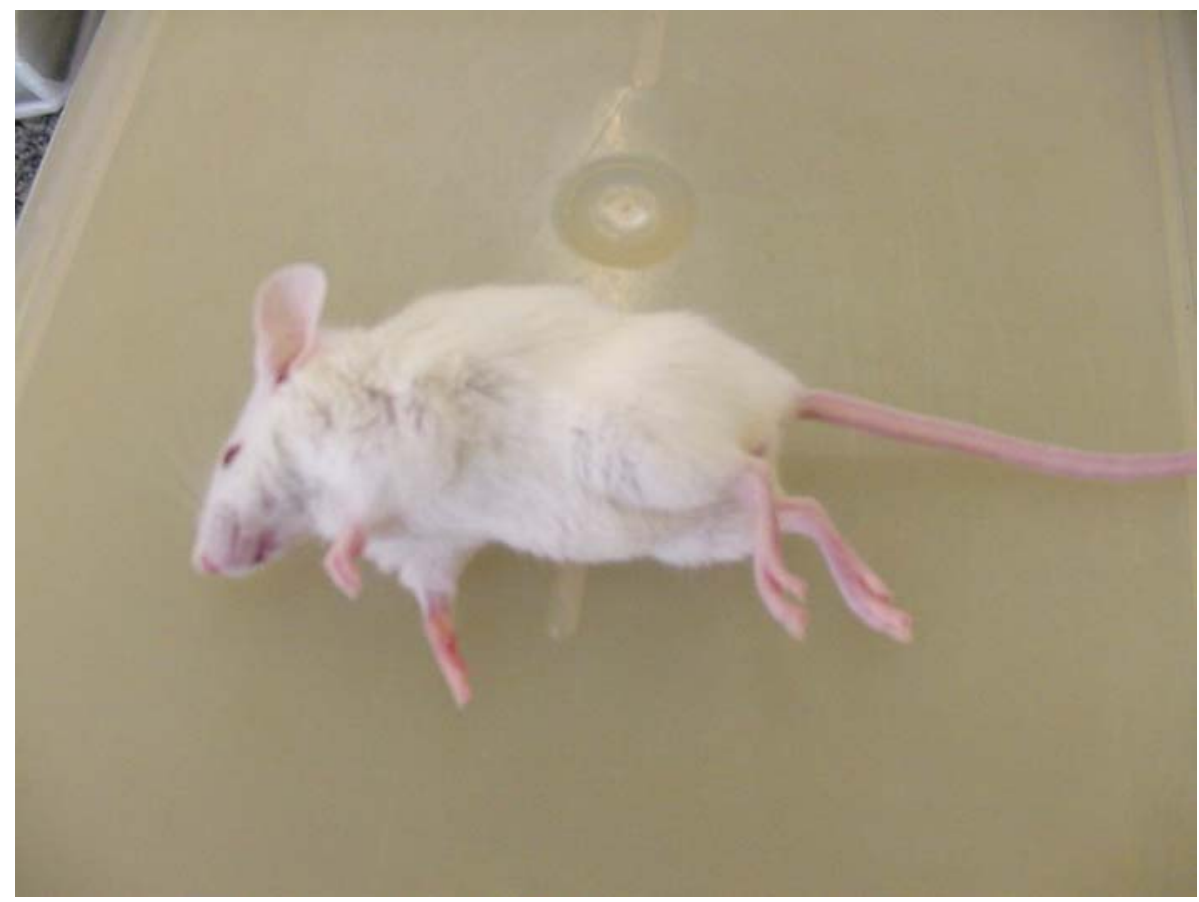

Figura 18 - Camundongo inoculado com o herpesvírus eqüino tipo 1 (HVE-1) apresentando severa dispnéia

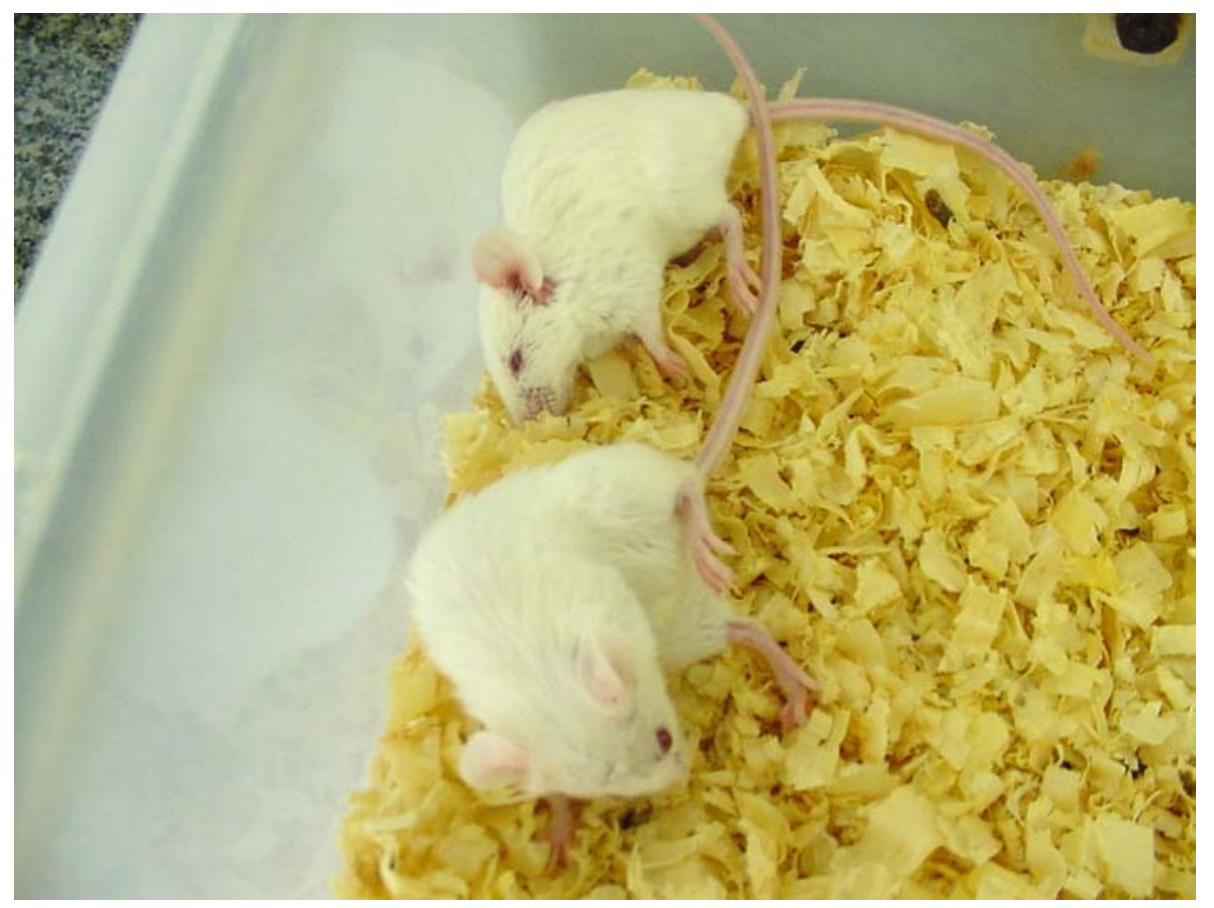

Figura 19- Camundongos inoculados com o herpesvírus eqüino tipo 1 (HVE-1) apresentando quadro convulsivo 


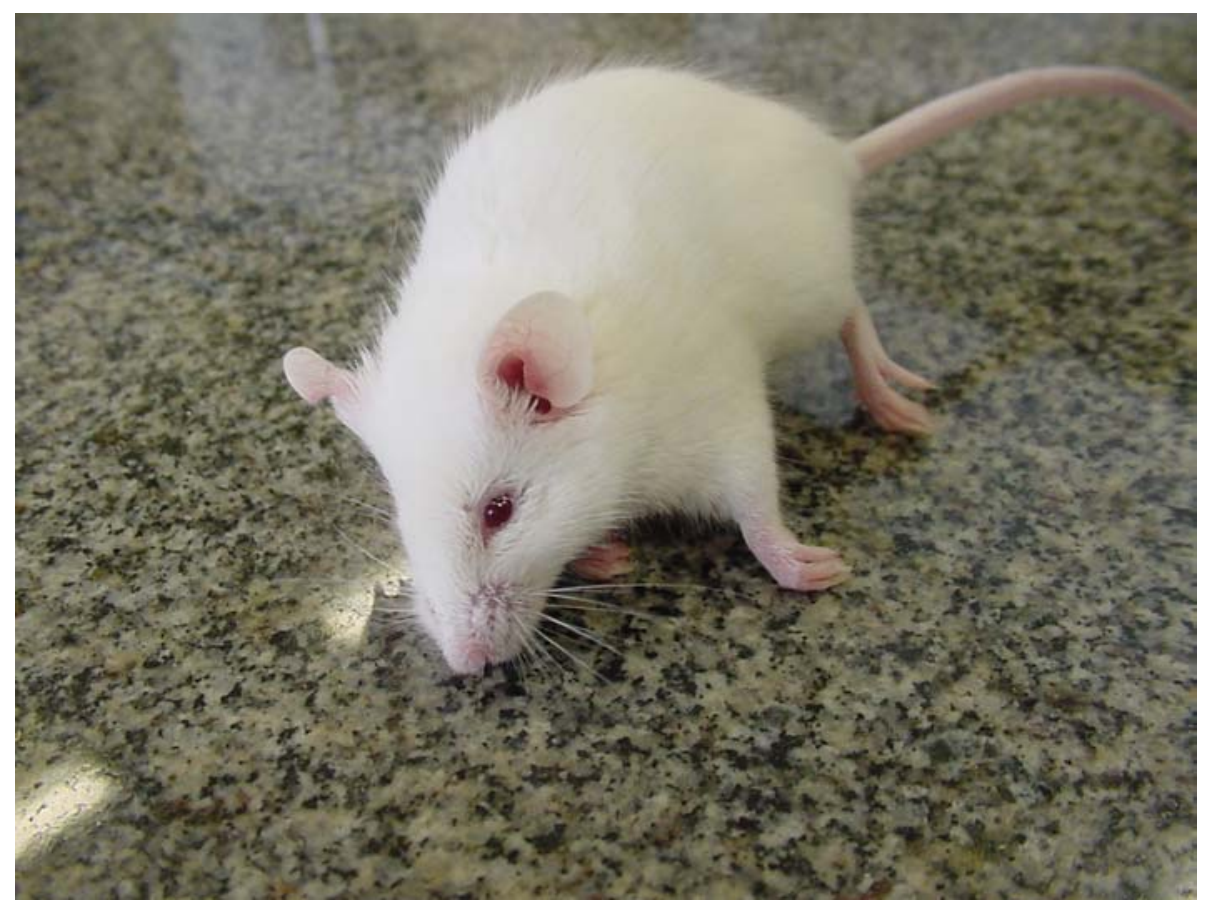

Figura 20 - Camundongo inoculado com o herpesvírus eqüino tipo 1 (HVE-1) apresentando diminuição na propriocepção

\subsubsection{EXAmes ANÁtomo e Histopatológico}

Não foram observadas alterações macroscópicas ou microscópicas nos diferentes órgãos internos (cérebro, pulmão, coração, fígado, rim e baço) dos camundongos dos grupos controle e experimental.

\subsubsection{ISOLAMENTO DO HVE-1}

O HVE-1 foi isolado dos fragmentos de pulmão dos sete camundongos que apresentaram manifestações clínicas, em cultura de células VERO. 
Os resultados obtidos no presente trabalho demonstraram a ocorrência de infecção respiratória leve e transitória em todos os cavalos, após a inoculação com o herpesvírus eqüino tipo 1 (HVE-1). Essa infecção restringiu-se às vias aéreas anteriores e apresentou-se sob a forma de rinite, de modo semelhante ao que descrevem outros autores (BURROWS; GOODRIDGE; DENYER, 1984; CRANDELL; DRYSDALE; STEIN, 1979; GIBSON et al., 1992a; GLEESON; COGGINS, 1980; KYDD et al., 1994a; MCCULLOCH et al., 1993; O’NEILL et al., 1999; STOKES; CORTEYN; MURRAY, 1991).

Esse achado foi evidenciado pelas manifestações clínicas, como corrimento nasal seroso ou seromucoso bilateral, aumento discreto dos linfonodos mandibulares, congestão das mucosas nasais e óculo-palpebrais com lacrimejamento, porém sem que houvesse o desenvolvimento de complicações secundárias como broncopneumonia, doenças oculares ou mesmo manifestações neurológicas.

Assim como relatam Mori et al. (2003) - que realizaram experimento no qual cavalos adultos foram inoculados com a mesma estirpe viral (A4/72) de origem fetal eqüina -, não foi constatada febre em nenhum dos animais no período de dez dias após a inoculação viral, provavelmente devido às respostas anamnésticas.

Além da resposta anamnéstica, outro importante fator que influencia a severidade das manifestações clínicas da infecção pelo HVE-1 é a natureza da estirpe viral e sua conseqüente virulência para a espécie eqüina (MUMFORD, 1994; MUMFORD; ROSSDALE, 1980).

Entretanto, animais submetidos a inoculações sucessivas com HVE-1 de estirpes comprovadamente virulentas para a espécie eqüina também não tiveram febre. Assim ocorreu com as estirpes 3551/80 (STOKES; CORTEYN; MURRAY, 
1991), Ab4 (GIBSON et al., 1992a; O'NEILL et al., 1999) e Army 183 (BREATHNACH et al., 2001). A manutenção de altos títulos de anticorpos soroneutralizantes protetores, conseqüentes aos repetidos desafios impostos por infecções experimentais ou naturais pelo HVE-1 reduziria a multiplicação viral no trato respiratório dos animais, causando enfermidade inaparente (BRYANS, 1969; BURROWS; GOODRIDGE, 1975; POWELL; BURROWS; GOODRIDGE, 1974).

Relatos da literatura demonstram a ocorrência de manifestações clínicas mais severas, incluindo febre e complicações secundárias, em primoinfecções pelo HVE-1 (BRIDGES; EDINGTON; 1986; GIBSON et al., 1992a; STOKES; CORTEYN; MURRAY, 1991; SUTTON et al., 1998). Por outro lado, Slater et al. (1994) observaram manifestações clínicas leves, com febre de curta duração, após primoinfecção em pôneis com a estirpe Ab4 mutante de HVE-1, deficiente em timidina quinase (tk).

De acordo com Mori (2000) e Raker (1982), os achados macroscópicos observados no exame endoscópico do trato respiratório anterior são considerados fisiológicos, e podem estar relacionados à faixa etária dos animais ou mesmo à condição ambiental à qual eles estão expostos. Lesões de caráter leve, como a hiperplasia linfóide faringeana de grau 1, podem ser observadas em decorrência de estímulos antigênicos ambientais, como a presença de poluentes atmosféricos ou particulados de cama ou de ração (RAKER, 1982; ROBERTSON, 1991). Outros pesquisadores, entretanto, verificaram alterações macroscópicas características da rinopneumonite eqüina em infecções experimentais pelo HVE-1, como hiperemia, ulcerações e necrose focal da mucosa da nasofaringe e presença de exsudato mucopurulento na traquéia (PRICKETT, 1970; SUTTTON et al.,1998). Sabe-se que o grau de lesão tecidual responsável pelo aparecimento das manifestações clínicas 
está intimamente relacionado à eficácia dos mecanismos de defesa da mucosa respiratória, como a quantidade de anticorpos neutralizantes virais locais disponíveis (BREATHNACH et al., 2001; BRYANS, 1969).

Embora a análise estatística do leucograma não tenha demonstrado diferenças entre os períodos pré e pós-inoculação nos dois grupos estudados, foram observadas variações individuais, com alteração na composição dos tipos celulares, nos primeiros dez dias após a inoculação com o HVE-1.

De forma semelhante a alguns relatos constantes da literatura, os animais 02 , 08, 09 e 10 apresentaram linfopenia após a inoculação com o HVE-1 (BUMGARDNER et al., 1982; DUTTA; MYRUP; BUMGARDNER, 1980; GIBSON et al., 1992a; MCCULLOCH et al., 1993; PERKINS et al., 1999; SCOTT; DUTTA; MYRUP, 1983). Nos estágios agudos das infecções virais, a linfopenia pode ocorrer como conseqüência de uma combinação de eventos, conforme segue: (1) migração de linfócitos $\mathrm{T}$ circulantes para os tecidos acometidos pelo processo infeccioso como, por exemplo, o trato respiratório; (2) seqüestro dos linfócitos T nos tecidos linfóides que drenam essas regiões; (3) replicação do HVE-1 no interior dos linfócitos T, com posterior destruição dos mesmos na fase de viremia (MCCULLOCH et al., 1993).

Houve também diminuição do número de neutrófilos, com conseqüente leucopenia, nos animais 04 (oitavo d.p.i.) e 10 (décimo d.p.i.). Esse achado assemelha-se àqueles mencionados por diversos autores, os quais também observaram neutropenia após a inoculação experimental com o HVE-1 (BUMGARDNER et al., 1982; GIBSON et al., 1992a; MCCULLOCH et al., 1993; PERKINS et al., 1999; SUTTON et al., 1998). A neutropenia após a infecção pelo HVE-1 ocorre em conseqüência da marginalização e da migração de neutrófilos 
circulantes para os tecidos acometidos pelo processo infeccioso, devido à liberação de substâncias quimiotáticas (JAIN, 1986; KYDD; HANNANT; MUMFORD, 1996).

Constatou-se neutrofilia associada a linfopenia e eosinopenia, em valores absolutos e relativos, nos animais 05 e 06 nos dias +05 e +01 pós-inoculação, respectivamente. Essas alterações hematológicas foram de caráter transitório e, provavelmente, devem ser de natureza fisiológica, conseqüente aos efeitos dos corticosteróides endógenos liberados pelos animais em resposta ao estresse causado pelas manipulações experimentais.

A maioria dos cavalos já apresentava títulos de anticorpos soroneutralizantes contra o HVE-1 no período pré-inoculação, o que está de acordo com os relatos da literatura para animais de faixa etária semelhante àquela dos cavalos utilizados no presente experimento (BRYANS; ALLEN, 1989; DOLL; BRYANS, 1962; MORI et al., 2003; MUMFORD, 1994). Estudos realizados no Estado de São Paulo revelaram que a infecção pelo HVE-1 é endêmica, pois está amplamente disseminada na população eqüina dessa região (CUNHA et al., 2002; FERNANDES, 1988; GAMA, 1992; KOTAIT et al., 1989a; KOTAIT et al., 1989b; LARA et al., 2003b; MODOLO et al., 1989; VASCONCELLOS, 1992). Animais adultos pertencentes a uma população na qual o HVE-1 é endêmico geralmente são positivos para a prova de neutralização viral, possuindo anticorpos neutralizantes que persistem em títulos altos por tempo prolongado, muitas vezes por mais de um ano (BRYANS; ALLEN, 1989; DOLL; BRYANS, 1962; MUMFORD, 1994; THOMSON et al., 1976).

Após a inoculação com o HVE-1, observou-se comportamento distinto entre os grupos experimentais em função da dose infectante. No grupo experimental I, somente dois cavalos apresentaram soroconversão dos títulos de anticorpos: o animal 02 , que era negativo, e o animal 03 , que possuía baixo título de anticorpos 
antes da inoculação viral. A soroconversão, ou seja, o aumento nos títulos de anticorpos neutralizantes superior a $10^{0,6}$ na fase de convalescença - após o dia +14 -, em relação à fase aguda da doença, indicou a ocorrência de infecção viral recente por esse agente (MORI et al., 2003; THOMSON et al., 1976). Os animais 01 e 04 apresentaram elevação nos títulos de anticorpos neutralizantes após a inoculação com o HVE-1, mas esse aumento foi insuficiente para ser considerado soroconversão. Já o animal 05 não apresentou resposta de anticorpos após a inoculação.

De modo semelhante, Allen e Bryans (1986), Bryans (1969) e Gibson et al. (1992b) relatam que cavalos com altos títulos de anticorpos neutralizantes prévios ao desafio viral não apresentaram resposta sorológica depois de repetidas infecções pelo HVE-1. Esses animais desenvolveram infecção restrita ao trato respiratório anterior, não sendo possível o isolamento viral das secreções nasais e dos leucócitos sangüíneos.

Por outro lado, os animais 08, 09 e 10 do grupo experimental II, apesar de possuírem títulos de anticorpos neutralizantes elevados, apresentaram soroconversão após a inoculação com o HVE-1. Segundo Donaldson (2003) e Mumford (1994), a submissão desses animais a um desafio viral maior poderia explicar o sucesso alcançado pelo agente na estimulação antigênica no período de 2 a 3 semanas após a inoculação.

Já o animal 06 apresentou soroconversão durante o período pré-inoculação, provavelmente devido à reativação do HVE-1 latente pela ação dos corticosteróides endógenos liberados pelo estresse, conforme evidenciado pelos resultados do leucograma (EDINGTON; BRIDGES; HUCKLE, 1985). 
Da mesma forma que os animais 01 e 04, o animal 07 também apresentou elevação no título de anticorpos neutralizantes após a inoculação com o HVE-1, mas sem soroconversão. Embora a maioria das viroses estimulem a produção de um alto título de anticorpos por volta de 2 a 3 semanas após a infecção, o HVE-1 é considerado uma exceção, pois algumas vezes provoca soroconversão somente 4 a 6 semanas após a infecção (BEECH, 1991; MUMFORD; ROSSDALE, 1980). Devido a isso, os anticorpos neutralizantes são descritos como uma ferramenta eficaz para determinar a ocorrência do vírus em uma população, mas apresentam menor sensibilidade que outras provas sorológicas, como a fixação de complemento, para avaliar a ocorrência de infecções recentes (BEECH, 1991; DOLL; BRYANS, 1962).

Diferentemente do que observaram Mori et al. (2003), não foi possível isolar o HVE-1 a partir de amostras de secreções nasais de qualquer um dos animais utilizados no presente trabalho nos primeiros dias pós-inoculação. Sabe-se que animais com infecções inaparentes podem apresentar eliminação viral curta, transitória - no período de 24 a 48 horas pós-infecção - e em pequena quantidade. Tal fato geralmente ocorre nos casos de reinfecções pelo HVE-1, nos quais a multiplicação do agente é reduzida e restringe-se ao trato respiratório anterior, nem sempre sendo detectada com sucesso pelos métodos diagnósticos convencionais de isolamento viral (ALLEN; BRYANS, 1986; BEECH, 1991; BRYANS, 1969; MUMFORD; ROSSDALE, 1980; SHARMA et al., 1992). Um aspecto que contribui para a redução da eliminação viral nas secreções nasais é o aumento dos títulos de anticorpos neutralizantes na mucosa nasal, como a imunoglobulina A (IgA) (BREATHNACH et al., 2001).

Em relação à citologia do LBA, os valores de referência apontados na literatura são variáveis (HEWSON; VIEL, 2002; SWEENEY; BEECH, 1991; VIEL, 
HEWSON, 2003), o que dificulta a correta interpretação dos resultados da análise laboratorial. Alguns fatores, como as diferentes técnicas de colheita e de processamento das amostras, a faixa etária dos animais, além de influências ambientais e genéticas - como raça e sexo -, poderiam explicar tais variações. Entretanto, até o presente momento não foram realizados estudos com a finalidade específica de determinar o grau de influência de cada um desses fatores na composição celular do fluido do LBA.

Assim sendo, a análise dos resultados da citologia do LBA obtidos no presente estudo baseou-se nos achados de Fernandes, Mori e Sanches (2000), em cuja investigação os animais haviam sido submetidos a condições experimentais bastante similares. Talvez por essa razão, os valores médios dos diferentes tipos celulares encontrados no fluido do LBA no período que antecedeu a inoculação com o HVE-1 tenham sido semelhantes àqueles apontados por tais autores para cavalos hígidos. Os macrófagos foram o tipo celular predominante, seguidos pelos linfócitos e, em menor número, os neutrófilos, os eosinófilos e os mastócitos. A composição celular e a ausência de células epiteliais cilíndricas ciliadas confirmaram a capacidade da técnica de lavagem broncoalveolar em obter amostras provenientes das vias aéreas mais distais e dos alvéolos (BAIN, 1997; ZINKL, 1992).

Alguns relatos da literatura demonstram que valores superiores a $5 \%$ de neutrófilos no LBA de cavalos são indicativos de neutrofilia relacionada à inflamação das vias aéreas (DIXON; RAILTON; MCGORUM, 1995a; MCGORUM; DIXON, 1994; MCGORUM; DIXON; HALLIWELL, 1993).

Os animais 01, 02, 03, 06, 08 e 09 desta investigação apresentaram valores superiores a $5 \%$ de neutrófilos alveolares no período pré-inoculação. Entretanto, o exame endoscópico das vias aéreas anteriores desses animais não detectou 
quantidade excessiva de muco, descartando-se assim a existência de um processo inflamatório. O efeito da estabulação é citado como fator responsável pelo aumento dos neutrófilos na população celular pulmonar em cavalos clinicamente saudáveis. Provavelmente, o influxo de neutrófilos nas vias aéreas ocorre como uma resposta não-específica à exposição à poeira orgânica no interior das baias, não estando relacionado com manifestação de doença respiratória (DERKSEN et al., 1985; HOLCOMBE et al., 2001; TREMBLAY et al., 1993). Além disso, a contagem diferencial da população neutrofílica também é influenciada pela faixa etária dos animais, ou seja, observam-se valores médios maiores que $15 \%$ em cavalos adultos (>6 anos) clinicamente saudáveis (VIEL; HEWSON, 2003).

No décimo-sexto dia pós-inoculação houve diminuição nos valores dos macrófagos alveolares do animal 07. Essa diminuição foi conseqüência do aumento do número dos neutrófilos e não da linfocitose, como verificaram Mori et al. (2003). Kydd, Hannant e Mumford (1996) observaram diminuição nos macrófagos alveolares no segundo dia pós-inoculação, o que não foi constatado no presente trabalho.

Embora a porcentagem de linfócitos alveolares observada nos animais 01, 02 , 03, 04, 05 e 10, em diferentes dias experimentais, tenha sido inferior aos percentuais apontados por outros pesquisadores (HOLCOMBE et al., 2001; KYDD; HANNANT; MUMFORD, 1996; MCGORUM; DIXON, 1993; MCGORUM; DIXON; HALLIWELL, 1993; TREMBLAY et al., 1993), ela está de acordo com os valores obtidos por Fernandes, Mori e Sanches (2000) e Mair, Stokes e Bourne (1987) para cavalos hígidos. Essa divergência pode estar relacionada à ampla faixa de variação dos valores dos linfócitos alveolares observada na espécie eqüina (MCGORUM; DIXON, 1994), ou à estirpe viral ou à pré-exposição ao agente. 
Diferentemente dos resultados obtidos por Kydd, Hannant e Mumford (1996), que revelaram diminuição do número de linfócitos alveolares no segundo dia pósinoculação com o HVE-1, não foi possível estabelecer uma relação entre as variações desse tipo celular e a ação do agente viral neste estudo.

Somente o animal 03 apresentou neutrofilia no LBA nos dez primeiros dias pós-inoculação, semelhantemente ao descrito por Kydd, Hannant e Mumford (1996). Segundo tais autores, a neutrofilia no LBA nos primeiros dias após a infecção com o HVE-1 pode estar relacionada ao recrutamento desse tipo celular em direção às áreas acometidas do trato respiratório, em virtude da liberação de substâncias quimiotáticas.

Outros autores, porém, não verificaram neutrofilia no LBA em cavalos infectados pelo vírus da rinopneumonite eqüina (DIXON; RAILTON; MCGORUM, 1995b; MORI et al., 2003). Da mesma forma, os animais 01, 02, 04, 08, 09 e 10 do presente experimento não apresentaram neutrofilia no LBA em nenhum momento após a inoculação.

A presença de neutrofilia no LBA dos animais 05, 06 e 07 entre o décimo sexto e trigésimo dias pós-inoculação pode não estar diretamente associada à infecção viral. Alguns fatores como lavagens sucessivas são capazes de influenciar a constituição da população celular pulmonar (CRISMAN et al., 1992; SWEENEY et al., 1994; TRAUB-DARGATZ et al., 1988), ou o procedimento de colheita do LBA pela passagem de um cateter pelas narinas -, poderia transferir alguns microrganismos pertencentes à microbiota normal da nasofaringe para as vias aéreas posteriores, resultando em inflamação local (CRISMAN et al., 1992). Outra possível causa dessa neutrofilia poderia ser as características físicas da solução salina infundida no LBA, em termos de $\mathrm{pH}$, conteúdo eletrolítico e osmolaridade 
(CRISMAN et al., 1992; SWEENEY et al., 1994; TRAUB-DARGATZ et al., 1988). Quantidades residuais de solução salina deixada nas vias aéreas após o procedimento de lavagem broncoalveolar poderiam também induzir resposta inflamatória (CLARK et al., 1995).

De modo geral, ocorreram alterações morfológicas sugestivas de menor atividade macrofágica durante a primeira semana pós-inoculação, com posterior ativação dessas células na fase de convalescença da infecção viral. Os macrófagos inativos eram pequenos, de formato esférico e regular, e notou-se a ausência de projeções e de vacúolos citoplasmáticos. Já os macrófagos ativados apresentaram formato variável, tornaram-se maiores, com citoplasma abundante e grande quantidade de vacúolos citoplasmáticos, o que Ihes conferia o aspecto de células espumosas. Foram observadas, com maior freqüência, partículas fagocitadas no interior de seu citoplasma, além de formas bi, tri e multinucleadas. Segundo Mori, Mori e Fernandes (2001) e Wong et al. (1990), as diferenças morfológicas observadas nos macrófagos ativados em relação aos macrófagos inativos estão relacionadas com alterações funcionais e metabólicas dessas células, no intuito de aumentar sua atividade antimicrobiana.

Em relação à detecção do DNA viral pela PCR, constataram-se padrões de amplificação divergentes entre os primers das regiões tk e gB. Enquanto os primers da região tk amplificaram somente o controle positivo vacinal derivado da estirpe Army 183 (Pneumoabort ${ }^{\circledR} \mathrm{K}+1 \mathrm{~b}$ Fort Dodge), os primers da região gB amplificaram de forma consistente todos os três controles positivos (vacina derivada da estirpe Army 183 , estirpe $A 4 / 72$ e vacina Equibort ${ }^{\circledR}$ Biovet). De maneira semelhante, Lawrence et al. (1994) e Sharma et al. (1992) observaram discrepâncias na detecção do DNA do HVE-1 utilizando primers escolhidos para diferentes regiões 
genômicas em uma mesma amostra clínica, o que sugere variações na sensibilidade desses oligonucleotídeos de acordo com a estirpe viral.

A seqüência de nucleotídeos da região-alvo, escolhida para amplificação com os primers da região tk, provavelmente não deve estar presente na estirpe A4/72 devido a uma variação genética nessa região em relação àquela descrita para a estirpe Ab4p - seqüenciada por Telford et al. (1992) -, da qual são derivados os desenhos de todos os primers para o HVE-1. Para a confirmação de possíveis variações genéticas entre as estirpes de um mesmo tipo viral, Sharma et al. (1992) sugerem o seqüenciamento dos nucleotídeos.

Já a detecção de DNA viral nas amostras de sangue e de LBA utilizando primers da região tk deu-se de forma dispersa e inconsistente, sugerindo a presença de infecção latente por outra estirpe do HVE-1, a qual provavelmente apresenta seqüência de nucleotídeos na região tk distinta daquela presente na estirpe A4/72, utilizada nas inoculações experimentais.

Segundo Kirisawa et al. (1993) os primers da região gB possuem alta sensibilidade para detectar o HVE-1 em diferentes estirpes, naturais (HH1 e KyD) ou atenuadas em cultivo celular (BK343). Outros autores utilizaram com sucesso os mesmos primers como ferramenta para a detecção do HVE-1 em vários países, como Japão (KIRISAWA et al., 1993), França (TAOUJI et al., 2002) e Austrália (WILCOX; RAIDAL, 2000).

Tendo em vista que a região do gene que codifica a glicoproteína B (gB) é considerada uma das mais conservadas entre os membros da família Herpesviridae (KIRISAWA et al., 1993; WAGNER et al., 1992; WELCH et al., 1992), a análise dos resultados da PCR para as amostras de sangue e de LBA dos cavalos inoculados com o HVE-1 baseou-se na seqüência amplificada por esses primers. 
Os animais 03, 04 e 06 apresentaram PCR positiva para o HVE-1 antes da inoculação viral, provavelmente em decorrência de infecção latente nos leucócitos sangüíneos, o que se assemelha aos achados de Carvalho et al. (2000b), que detectaram DNA viral em 88\% das amostras de 116 cavalos provenientes de diferentes Estados brasileiros. Outros autores também detectaram alta prevalência da infecção latente pelo HVE-1 em cavalos provenientes do Reino Unido (EDINGTON; WELCH; GRIFFTHS, 1994) e da França (TAOUJl et al., 2002), utilizando técnicas de PCR.

No presente estudo, o período de detecção máxima do HVE-1 nos leucócitos sangüíneos ocorreu entre o terceiro e o oitavo dias pós-inoculação em todos os animais de ambos os grupos. É interessante salientar que outros pesquisadores apontam esse período como ideal para a detecção da viremia pelo isolamento viral (ALLEN, 2002a; BRYANS, 1969). Portanto, tais resultados são indicativos de que os animais desenvolveram viremia após a inoculação com o HVE-1.

No grupo experimental I, a presença de DNA viral somente foi detectada no LBA dos cavalos 02 e 04 na fase aguda da doença (dia +09 pós-inoculação), sugerindo que tais animais tinham baixo nível de infecção aguda ou lítica viral nas células pulmonares. É provável que esse fato seja conseqüência da manifestação leve da rinopneumonite, com replicação viral limitada no trato respiratório anterior, refletida também pelo isolamento viral negativo das secreções nasais. Por outro lado, mesmo em quadros mais severos de rinopneumonite aguda, com desenvolvimento de pirexia e viremia, Kydd et al. (1994a) verificaram que a presença de partículas infecciosas virais nos pulmões foi um evento transitório e de curta duração após a inoculação com o HVE-1. 
Já o resultado positivo da PCR para o HVE-1 no LBA do animal 02 no trigésimo d.p.i. pode ser conseqüente à detecção da forma latente desse vírus, pois foi um evento isolado e tardio. Entretanto, não é possível descartar um baixo nível de infecção persistente no trato respiratório. Esse resultado está de acordo com os achados de outros autores, que descrevem baixa detecção do HVE-1 pela PCR no LBA de cavalos sem manifestações clínicas de rinopneumonite (EDINGTON; WELCH; GRIFFITHS, 1994; WILCOX; RAIDAL, 2000). Slater et al. (1994) verificaram que, após imunossupressão, a habilidade de reativação do HVE-1 latente nas células pulmonares é menor do que no nervo trigêmeo, fato esse que poderia explicar a baixa sensibilidade de detecção pela PCR nas amostras de LBA.

A maioria dos cavalos do grupo experimental II apresentaram PCR positiva para HVE-1 no LBA no nono dia pós-inoculação, ou seja, na fase aguda da doença. Esses resultados são indicativos de uma replicação ativa do vírus nas células pulmonares a qual, provavelmente, está relacionada com o maior desafio viral imposto a esses animais. Kydd et al. (1994a) e Patel, Edington e Mumford (1982) obtiveram isolamento viral positivo a partir das células pulmonares de cavalos até o oitavo d.p.i. com o HVE-1, confirmando a ocorrência de replicação viral nesses tipos celulares na fase aguda da rinopneumonite.

A detecção do DNA viral no LBA de todos os cavalos do grupo experimental II, a partir do décimo-sexto dia pós-inoculação, é sugestiva de uma replicação viral ativa persistente. Entretanto, a hipótese de infecção latente não pode ser descartada por tratar-se de um evento tardio à inoculação. Devido à alta sensibilidade da PCR, a detecção do HVE-1 ocorre em situações nas quais os animais não apresentam manifestações clínicas, ou seja, em infecções inaparentes que não seriam diagnosticadas pelos métodos convencionais de isolamento viral e de sorologia 
(REUBEL; STUDDERT, 1998). Esse quadro torna difícil a interpretação dos resultados, pois a PCR utilizada nesta investigação é considerada um método qualitativo.

Segundo Slater (2001), durante a infecção latente pelo HVE-1 não se observa replicação viral, a transcrição dos genes está restrita a uma única região do genoma e não ocorre a tradução do RNA mensageiro. Além disso, a expressão dos antígenos virais na superfície celular está ausente, não ocorre destruição das células infectadas e as partículas virais não são liberadas. Dessa forma, para determinar a carga viral presente nas amostras clínicas é necessário utilizar técnicas complementares quantitativas como, por exemplo, a PCR em tempo real.

Conforme mencionado anteriormente, os achados clínicos e laboratoriais, após a inoculação com o HVE-1 permitiram concluir que os cavalos desenvolveram uma infecção respiratória leve e transitória, provavelmente devido à influência de fatores intrínsecos como idade e nível de imunidade humoral. Entretanto, outras variáveis, como a dose infectante e a patogenicidade da estirpe do vírus envolvido na etiologia da doença, também foram investigadas.

Embora os cavalos do grupo experimental II tenham recebido uma dose infectante cinco vezes maior do que aqueles do grupo experimental I, as manifestações clínicas foram idênticas em ambos os grupos. Entretanto, notou-se que a resposta dos anticorpos soroneutralizantes e a detecção do DNA viral no LBA foram influenciadas pelo desafio viral.

Então, questionou-se a virulência da estirpe A4/72 utilizada nos experimentos, que é mantida em cultura de células VERO com quinze passagens desde seu isolamento por Reiner et al. (1972), e sabe-se que o vírus pode ser atenuado devido 
a sucessivas passagens em células que não sejam provenientes da espécie-alvo (OSTERRIEDER et al., 1994).

A inoculação experimental em animais de laboratório é um método fácil e eficiente para confirmar a virulência do HVE-1. Segundo Van Woensel et al. (1995), as estirpes patogênicas para cavalos geralmente também são responsáveis pelo aparecimento de manifestações clínicas severas em camundongos.

Os resultados da inoculação experimental em camundongos com a estirpe A4/72 do HVE-1, por via intranasal, demonstraram a ocorrência de manifestações clínicas semelhantes àquelas descritas na literatura, como conjuntivite bilateral mucopurulenta, pelame áspero, sem brilho e eriçado, desidratação, apatia, arqueamento de dorso, taquipnéia e dispnéia (AWAN; CHONG; FIELD, 1990; GALOSI et al., 2004; INAZU et al., 1993; VAN WOENSEL et al., 1995; WALKER; LOVE; WHALLEY, 1999; WALKER et al., 1998). No terceiro d.p.i. foram observadas manifestações neurológicas, como diminuição na propriocepção, hiperexcitabilidade e convulsões. Para Awan, Chong e Field (1990) e Walker, Love e Whalley (1999), o neurotropismo é um comportamento incomum para o HVE-1 quando este é inoculado por via intranasal em camundongos. A neuropatogenicidade nessa espécie somente foi comprovada com a utilização de estirpes previamente adaptadas em células neuronais (HASEBE et al., 2002).

À semelhança do que verificaram outros pesquisadores, o tropismo do HVE-1 pelo trato respiratório de camundongos foi confirmado pelo isolamento viral em cultivo celular, a partir de fragmentos de pulmões dos animais inoculados (AWAN; CHONG; FIELD, 1990; INAZU et al., 1993; VAN WOENSEL et al., 1995; WALKER; LOVE; WHALLEY, 1999; WALKER et al., 1998). 
Neste experimento, variáveis intrínsecas como faixa etária e nível de imunidade puderam ser controladas, pois foram utilizados camundongos isogênicos BALB/c, livres de patógenos específicos (SPF), recém-desmamados - faixa etária mais susceptível ao vírus -, os quais não haviam tido contato prévio com o vírus, ou seja, eram imunologicamente inexperientes.

A severidade das manifestações clínicas observadas nesses animais, associada ao isolamento viral positivo, permitiu que se concluísse que a estirpe A4/72 do HVE-1 manteve a sua virulência in vivo.

A ocorrência de manifestações neurológicas severas em camundongos inoculados por via intranasal, além de resultados divergentes na amplificação pelos primers das regiões tk e gB, indicam que a estirpe $\mathrm{A} 4 / 72$ possui um comportamento distinto daquele das demais estirpes do HVE-1 descritas na literatura. Então, para melhor caracterizar esse vírus, são necessários estudos mais aprofundados, que contemplem, por exemplo, inoculações experimentais em cavalos e em animais de laboratório, escolha de primers para a PCR baseados em outras regiões genômicas e seqüenciamento dos nucleotídeos desse vírus. 


\section{Conclusões}


Nas condições de realização do presente trabalho, os resultados obtidos permitiram as seguintes conclusões:

6.1 A reprodução do quadro mórbido da rinopneumonite, após a inoculação com o HVE-1, foi característico de eqüinos que já tiveram contato prévio com o agente, ou seja, ocorreu manifestação respiratória de caráter leve e transitório, restrita às vias aéreas anteriores. Essas manifestações foram idênticas em ambos os grupos, indicando que não houve influência da dose infectante.

6.2 A análise do leucograma, no período pós-inoculação com o HVE-1, demonstrou a ocorrência de linfopenia e de neutropenia em poucos animais, refletindo um leve grau de envolvimento desses tipos celulares no trato respiratório e nos tecidos linfóides frente ao desafio viral em cavalos adultos.

6.3 A resposta imune humoral conseqüente à inoculação com o HVE-1 foi de caráter anamnéstico e sofreu influência da dose infectante. Os cavalos submetidos ao maior desafio viral, mesmo já possuindo elevados títulos de anticorpos, apresentaram soroconversão no período pós-inoculação.

6.4 O isolamento do HVE-1 a partir de amostras das secreções nasais não foi bem sucedido, indicando a ocorrência de eliminação viral transitória e em quantidade insuficiente para produzir efeito citopático em cultivo celular.

6.5 No exame citológico do LBA não foram observadas alterações decorrentes da infecção pelo HVE-1 na composição dos tipos celulares. Já na análise morfológica, notou-se de maneira geral a ocorrência de ativação dos 
macrófagos alveolares na fase de convalescença da infecção, refletindo as alterações funcionais e metabólicas sofridas por essas células frente ao desafio viral.

6.6 A detecção pela PCR do HVE-1 nos leucócitos sangüíneos demonstrou a ocorrência de viremia entre o terceiro e o oitavo dias pós-inoculação. A detecção do DNA viral no LBA evidenciou a presença de infecção lítica aguda nos dez primeiros dias pós-inoculação e, na fase mais tardia, houve replicação viral ativa persistente dependente da dose infectante nos leucócitos pulmonares.

6.7 A PCR demonstrou ser uma técnica de alta sensibilidade para o diagnóstico do HVE-1, capaz de detectar a presença do DNA viral mesmo quando não ocorre a constatação do agente pelos métodos tradicionais. 
ALLEN, G. P. Epidemic disease caused by equine herpesvirus-1: recommendations for prevention and control. Equine Veterinary Education, Newmarket, v. 14, n. 3, p. 136-142, June 2002b.

ALLEN, G. P. Equine rhinopneumonitis. In: TRUSZCZYNSKI, M.; PEARSON, J. E.; EDWARDS, S.; SCHMITT, B. Office international des épizooties: manual of standards for diagnostic tests and vaccines. 4. ed. Paris: O.I.E. Press, 2000, p. 565-575.

ALLEN, G. P. Respiratory infections by equine herpesvirus types 1 and 4 . In: LEKEUX, P. Equine respiratory diseases. New York: International Veterinary Information Service (IVIS), 2002a. Disponível em: <http://www.ivis.org>. Acesso em: 09 nov. 2002.

ALLEN, G. P.; BRYANS, J. T. Molecular epizootiology, pathogenesis, and prophylaxis of equine herpesvirus-1 infectious. In: PANDEY, R. Progress in veterinary microbiology and immunology: veterinary microbiology. Basel: D. Karger, 1986. p. 78-144.

AWAN, A. R.; CHONG, Y. C.; FIELD, H. J. The pathogenesis of equine herpesvirus type 1 in the mouse: a new model for studying host responses to the infection. Journal of General Virology, Berks, v. 71, n. 5, p. 1131-1140, May 1990.

AZMI, M.; FIELD, H. J. Interactions between herpesvirus type 1 and equine herpesvirus type 4: T cell responses in a murine infection model. Journal of General Virology, Berks, v. 74, n. 11, p. 2339-2345, Nov. 1993.

BAIN, F. T. Cytology of the respiratory tract. The Veterinary Clinics of North America Equine Practice, Philadelphia, v. 13, n. 3, p. 477-486, Dec. 1997.

BALLAGI-PORDÁNY, A.; KLINGEBORN, B.; FLENSBURG, J.; BELÁK, S. Equine herpesvirus type 1: detection of viral DNA sequences in aborted fetuses with the polymerase chain reaction. Veterinary Microbiology, Amsterdam, v. 22, n. 4, p. 373-381, May 1990.

BASCUÑANA, C. R. Diagnostic application of the polymerase chain reaction (PCR) in veterinary medicine. 1997. $47 \mathrm{f}$. Doctoral thesis - Swedish University of Agricultural Sciences, Uppsala, 1997.

BAXI, M. K.; BORCHERS, K.; BARTELS, T.; SCHELLENBACH, A.; BAXI, S.; FIELD, $H$. J. Molecular studies of the acute infection, latency and reactivation of equine herpesvirus-1 (EHV-1) in the mouse model. Virus Research, Amsterdam, v. 40, n. 1, p. 33-45, Jan. 1996.

$\mathrm{BEECH}, \mathrm{J}$. Infections caused by viruses. In: Equine respiratory disorders. Philadelphia: Lea \& Febiger, 1991. p. 153-180.

Conforme as diretrizes para apresentação de dissertações e teses na Faculdade de Medicina Veterinária e Zootecnia da Universidade de São Paulo. 4.ed. São Paulo: FMVZ-USP, 2003. 84 p. 
BIRGEL, E. H. Patologia Clínica Veterinária. In: BIRGEL, E. H.; BENESI, F. J. Patologia clínica veterinária. São Paulo: Sociedade Paulista de Medicina Veterinária, 1982, p. 1-50.

BÖRCHERS, K.; FRÖLICH, K. Antibodies against equine herpesviruses in freeranging mountain zebras from Namibia. Journal of Wildlife Diseases, Lawrence, $v$. 33, n. 4, p. 812-817, Oct. 1997.

BÖRCHERS, K.; FRÖLICH, K.; LUDWIG, H. Detection of equine herpesvirus types 2 and 5 (EHV-2 and EHV-5) in Przewalski's wild horses. Archives of Virology, Wein, v. 144, n. 4, p. 771-780, Apr. 1999.

BÖRCHERS, K.; SLATER, J. A nested PCR for detection and differentiation of EHV1 and EHV-4. Journal of Virology Methods, Amsterdam, v. 45, n. 3, p. 331-336, Dec. 1993.

BREATHNACH, C. C.; YEARGAN, M. R.; SHEORAN, A. S.; ALLEN, G. P. The mucosal humoral immune response of the horse to infective challenge and vaccination with equine herpesvirus-1 antigens. Equine Veterinary Journal, Newmarket, v. 33, n. 7, p. 651-657, Nov. 2001.

BRIDGES, C. G.; EDINGTON, N. Innate immunity during equid herpesvirus (EHV-1) infection. Clinical and Experimental Immunology, Oxford, v. 65, n. 1, p. 172-181, Jul. 1986.

BROWNING, G. F.; FICORILLI, N.; STUDDERT, M. J. Asinine herpesvirus genomes: comparison with those of the equine herpesvirus. Archives of Virology, Wein, $v$. 101, n. 3-4, p. 183-190, 1988.

BRYANS, J. T. On immunity to disease caused by equine herpesvírus 1 . Journal of the American Veterinary Medical Association, Schaumburg, v. 155, n. 2, p. 294300, July, 1969.

BRYANS, J. T.; ALLEN, G. P. Herpesviral diseases of the horse. In: WITTMANN, G. Herpesvirus diseases of cattle, horses, and pigs. Boston: Kluwer Academic Publishers, 1989. p. 176-229.

BUMGARDNER, M. K.; DUTTA, S. K.; CAMPBELL, D. L.; MYRUP, A. C. Lymphocytes from ponies experimentally infected with equine herpesvirus 1 : subpopulation dynamics and their response to mitogens. American Journal Veterinary Research, Schaumburg, v. 43, n. 7, p. 1308-1310, July 1982.

BURROWS, R.; GOODRIDGE, D. Experimental studies on equine herpesvirus type 1 infections. The Journal Reproduction Fertility Supplement, Oxford, v. 23, p. 611615, Oct. 1975.

BURROWS, R.; GOODRIDGE, D.; DENYER, M. S. Trials of an inactivated equid herpesvirus 1 vaccine: Challenge with a subtype 1 virus. The Veterinary Record, London, v. 114, n. 15, p. 369-74, Apr. 1984.

CAMPBELL, T. M.; STUDDERT, M. J. Equine herpesvírus type 1 (EHV1). Veterinary Bulletin, Wallingford, v. 53, n. 2, p. 135-146, Feb. 1983. 
CANADIAN COUNCIL ON ANIMAL CARE (CCAC). In: OLFERD, E. D.; CROSS, B. M.; MCWILLIAM, A. A. Guide to the care and use of experimental animals. Ottawa: Canadian Council on Animal Care, 1993, v. 1, p. 63-64.

CARVALHO, R.; OLIVEIRA, A. M.; SOUZA, A. M.; PASSOS, L. M. F.; MARTINS, A. $S$. Prevalence of equine herpesvirus type 1 latency detected by polymerase chain reaction. Arquives of Virology, Wein, v. 145, n. 9, p. 1773-1787, Sept. 2000b.

CARVALHO, R.; PASSOS, L. M. F.; MARTINS, A. S. Development of a differential multiplex PCR assay for equine herpesvirus 1 and 4 as a diagnostic tool. Journal of Veterinary Medicine B, Berlin, v. 47, n. 5, p. 351-359, June 2000.

CARVALHO, R.; PASSOS, L. M. F.; OLIVEIRA, A. M.; HENRY, M.; MARTINS, A. S. Detection of equine herpesvirus 1 DNA in a single embryo and in horse semen by polymerase chain reaction. Arquivo Brasileiro de Medicina Veterinária e Zootecnia, Belo Horizonte, v. 52, n. 4, p. 302-306, Ago. 2000a.

CHOMCZYNSKI, P. A reagent for the single-step simultaneous isolation of RNA, DNA and proteins from cells and tissue samples. Biotechniques, Natick, v. 15, n. 3, p. 532-537, 1993.

CLARK, C. K.; LESTER, G. D.; VETRO, T.; RICE, B. Bronchoalveolar lavage in horses: effect of exercise and repeated sampling on cytology. Australian Veterinary Journal, Melbourne, v. 72, n. 7, p. 249-252, July 1995.

CORREAA, W. M.; NILSSON, M. R. Observações preliminares sobre o aborto eqüino a vírus no Brasil. Arquivos do Instituto Biológico, São Paulo, v. 31, n. 3, p. 13-15, 1964.

CRABB, B. S.; STUDDERT, M. J. Equine herpesviruses 4 (equine rhinopneumonitis virus) and 1 (equine abortion virus). Advances in Virus Research, San Diego, v. 45, p. 153-190, 1995.

CRANDELL, R. A. Selected animal herpesviruses: new concepts and technologies. Advances in Veterinary Science and Comparative Medicine, London, v. 29, p. 281-327, 1985.

CRANDELL, R. A.; DRYSDALE, S.; STEIN, T. L. A comparative study of bovine herpesvirus 1247 and equine herpesvirus 1 in ponies. Canadian Journal of Comparative Medicine, Ottawa, v. 43, n. 1, p. 94-97, Jan. 1979.

CRISMAN, M. V.; HODGSON, D. R.; BAYLY, W. M.; LIGGITT, H. D. Effects of transport on constituents of bronchoalveolar lavage fluid from horses. The Cornell Veterinarian, New York, v. 82, n. 3, p. 233-246, July, 1992.

CUNHA, E. M. S.; DE FERRARI, C. I., LARA, M. C. C. S. H.; SILVA, L. H. Q. Presença de anticorpos contra o herpesvírus eqüino 1 (HVE-1) em eqüinos do noroeste do Estado de São Paulo. Arquivos do Instituto Biológico, São Paulo, v. 69, n. 1, p. 1-5, Jan.-Mar. 2002. 
DERKSEN, F. J.; SCOTT, J. S.; MILLER, D. C.; SLOCOMBE, R. F.; ROBINSON, N. $E$. Bronchoalveolar lavage in ponies with recurrent airway obstruction (heaves). American Review of Respiratory Diseases, v. 132, n. 5, p. 1066-1070, Nov. 1985.

DIMOCK, W. W.; EDWARDS, P. R. the differential diagnosis of equine abortion with special reference to a hitherto undescribed form of epizootic abortion of mares. The Cornell Veterinarian, New York, v. 26, n. 3, p. 231-240, July 1936.

DIRKSEN, G.; GRÜNDER, H. -D; STÖBER, M. In: Rosenberger Exame Clínico dos Bovinos. 3. ed. Rio de Janeiro: Guanabara Koogan S.A., 1993. 419 p.

DIXON, P. M.; RAILTON, D. I.; MCGORUM, B. C. Equine pulmonary disease: a case control study of 300 referred cases. part 1: examination techniques, diagnostic criteria and diagnoses. Equine Veterinary Journal, Newmarket, v. 27, n. 6, p. 416421, Nov. 1995a.

DIXON, P. M.; RAILTON, D. I.; MCGORUM, B. C. Equine pulmonary disease: a case control study of 300 referred cases. part 3: ancillary diagnostic findings. Equine Veterinary Journal, Newmarket, v. 27, n. 6, p. 428-435, Nov. 1995b.

DOLL, E. R.; BRYANS, J. T. Development of complement-fixing and virus neutralizing antibodies in viral rhinopneumonitis of horses. American Journal Veterinary Research, Schaumburg, v. 23, n. 95, p. 843-846, July 1962.

DONALDSON, M. T. Equine herpesvirus. In: ROBINSON, N. E. Current Therapy Equine Medicine. 5. ed. Philadelphia: W.B. Saunders, 2003. p. 38-42.

DUTTA, S. K.; MYRUP, A. C.; BUMGARDNER, M. K. Lymphocytes responses to virus and mitogen in ponies during experimental infection with equine herpesvirus-1. American Journal Veterinary Research, Schaumburg, v. 41, n. 12, p. 2066-2068, Dec. 1980.

EDINGTON, N.; BRIDGES, C. G.; HUCKLE, A. Experimental reactivation of equid herpesvírus 1 (EHV 1) following the administration of corticosteroids. Equine Veterinary Journal, Newmarket, v. 17, n. 5, p. 369-372, Sep. 1985.

EDINGTON, N.; WELCH, H. M.; GRIFFITHS, L. The prevalence of latent of equid herpesvírus 1 in the tissues of 40 abattoir horses. Equine Veterinary Journal, Newmarket, v. 26, n. 2, p. 140-142, Mar. 1994.

FERNANDES, W. R. Determinação da infecção por herpesvírus eqüino tipo-1 em animais criados no Estado de São Paulo, através da reação de fixação do complemento. 1988. 64 f. Dissertação (Mestrado em Medicina Veterinária) Faculdade de Medicina Veterinária e Zootecnia, Universidade de São Paulo, São Paulo, 1988.

FERNANDES, W. R. Estudo clínico e da dinâmica de imunoglobulinas séricas e no lavado broncoalveolar de eqüinos experimentalmente infectados com herpesvírus eqüino tipo 1. 2001. 92 f. Tese (Livre-docência) - Faculdade de Medicina Veterinária e Zootecnia, Universidade de São Paulo, São Paulo, 2001. 
FERNANDES, W. R., MORI, E., SANCHES, A. Avaliação citológica de lavados traqueobrônquico e broncoalveolar em cavalos clinicamente sadios pelo método de coloração de Rosenfeld. Arquivo Brasileiro de Medicina Veterinária e Zootecnia, Belo Horizonte, v. 52, n. 6, p. 604-609, Dez. 2000.

FERNANDES, W. R.; SANCHES, A. Utilização da citologia do lavado traqueobrônquico no diagnóstico de afecções virais do sistema respiratório de eqüinos. Ars Veterinária, Jaboticabal, v. 18, n. 1, p. 25-32, Abr. 2002.

FICORILLI, N.; STUDDERT, M. J.; CRABB, B. S. The nucleotide sequence of asinine herpesvirus 3 glycoprotein $G$ indicates that the donkey virus is closely related to equine herpesvirus 1. Arquives of Virology, Wein, v. 140, n. 9, 1653-1662, 1995.

FOOTE, C. E.; LOVE, D. N.; GILKERSON, J. R.; WHALLEY, J. M. Detection of EHV1 and EHV-4 DNA in unweaned thoroughbred foals from vaccinated mares on a large stud farm. Equine Veterinary Journal, Newmarket, v. 36, n. 4, p. 341-345, May 2004.

FUKUSHI, H.; TOMITA, T.; TANIGUCHI, A.; OCHIAI, Y.; KIRISAWA, R.; MATSUMURA, T.; YANAI, T.; MASEGI, T.; YAMAGUCHI, T.; HIRAI, K. Gazelle herpesvírus 1: a new neurotropic herpesvírus immunologically related to equine herpesvírus 1. Virology, Oxford, v. 227, n. 1, p. 34-44, Jan. 1997.

GALOSI, C. M.; BARBEITO, C. G.; VILA ROZA, M. V.; CID DE LA PAZ, V.; AYALA, M. A.; CORVA, S. G.; ETCHEVERRIGARAY, M. E.; GIMENO, E. J. Argentine strain of equine herpesvirus 1 isolated from an aborted foetus shows low virulence in mouse respiratory and abortion models. Veterinary Microbiology, Amsterdam, v. 103, n. 1-2, p. 1-12, Oct. 2004.

GALOSI, C. M.; VILA ROZA, M. V.; OLIVA, G. A.; PECORARO, M. R.; ECHEVERRIA, M. G.; CORVA, S.; ETCHEVERRIGARAY, M. E. A polymerase chain reaction for detection of equine herpesvirus 1 in routine diagnostic submission of tissues from aborted foetuses. Journal of Veterinary Medicine B, Berlin, v. 48, n. 5, p. 341-346, June 2001.

GAMA, L. Estudo comparativo de técnicas para o diagnóstico sorológico da rinopneumonite eqüina. 1992. 94 f. Dissertação (Mestrado em Microbiologia) Instituto de Ciências Biomédicas, Universidade de São Paulo, São Paulo, 1992.

GIBSON, J. S.; O’NEILL, T. O.; THACKRAY, A.; HANNANT, D.; FIELD, H. J. Serologic responses of specific pathogen-free foals to equine herpesvírus-1: primary and secondary infections, and reactivation. Veterinary Microbiology, Amsterdam, v. 32, n. 3-4, p. 199-214, Oct. 1992b.

GIBSON, J. S.; SLATER, J. D.; AWAN, A. R.; FIELD, H. J. Pathogenesis of equine herpesvírus-1 in specific pathogen-free foals: primary and secondary infections and reactivation. Archives of Virology, Wein, v. 123, n. 3-4, p. 351-366, 1992a.

GILKERSON, J. R.; WHALLEY, J. M.; DRUMMER, H. E.; STUDDERT, M. J.; LOVE, D. N. Epidemiology studies of equine herpesvirus 1 (EHV-1) in thoroughbred foals: a review of studies conducted in the Hunter Valley of New South Wales between 1995 and 1997. Veterinary Microbiology, Amsterdam, v. 68, n. 1-2, p. 15-25, Aug. 1999a. 
GILKERSON, J. R.; WHALLEY, J. M.; DRUMMER, H. E.; STUDDERT, M. J.; LOVE, D. N. Epidemiology of EHV-1 and EHV-4 in the mare and foals populations on the Hunter Valley stud farm: are mares the source of EHV-1 for unweaned foals.

Veterinary Microbiology, Amsterdam, v. 68, n. 1-2, p. 27-34, Aug. 1999b.

GLEESON, L. J.; COGGINS, L. Response of pregnant mares to equine herpesvirus 1 (EHV1). The Cornell Veterinarian, New York, v. 70, n. 4, p. 391-400, Oct. 1980.

GRAPHPAD INSTAT. The instat guide to choosing and interpreting statistical tests. Versão 3.0132 bit para Windows 95/NT. San Diego: GraphPad Software, 1998. 153 p.

GUPTA, A. K.; RATTAN, B.; MALIK, P.; KAUR, D.; SINGH, B. K.; YADAV, M. P. Experimental infection of donkeys with EHV-1 of horse origin - a study. Journal of Equine Science, v. 11, n. 2, p. 29-33, June 2000.

GUPTA, A. K.; SINGH, B. K.; YADAV, M. P. Application of polymerase chain reaction (PCR) for diagnosis of equine herpesvirus-1 (EHV-1). Indian Journal of

Experimental Biology, New Delhi, v. 34, n. 11, p. 1077-1080, Nov. 1996.

HASEBE, R.; KIMURA, T.; SATO, E.; OKAZAKI, K.; OCHIAI, K.; WADA, R.; UMEMURA, T. Equine herpesvirus-1-induced encephalomyelitis in mice: a comparative study of neuroadapted virus and its parental strain. Journal of Comparative Pathology, London, v. 127, n. 2-3, p. 118-125, Oct. 2002.

HEINEMANN, M. B.; CORTEZ, A.; SOUZA, M. C. C.; GOTTI, T.; FERREIRA, F.; HOMEM, V. S. F.; FERREIRA NETO, J. S.; SOARES, R. M.; SAKAMOTO, S. M.; CUNHA, E. M. S. RICHTZENHAIN, L. J. Soroprevalência da anemia infecciosa eqüina, da arterite viral dos eqüinos e do aborto viral eqüino no município de Uruará, PA, Brasil. Brazilian Journal of Veterinary Research and Animal Science, São Paulo, v. 39, n. 1, p. 50-53, 2002.

HEWSON, J.; VIEL, L. Sampling, microbiology and cytology of the respiratory tract. In: LEKEUX, P. Equine respiratory diseases. New York: International Veterinary Information Service (IVIS), 2002. Disponível em: <http://www.ivis.org>. Acesso em: 09 nov. 2002.

HOLCOMBE, S. J.; JACKSON, C.; GERBER, V.; JEFCOAT, A.; BERNEY, C.; EBERHARDT, S.; ROBINSON, N. E. Stabling is associated with airway inflammation in young Arabian horses. Equine Veterinary Journal, Newmarket, v. 33, n. 3, p. 244-249, May 2001.

INAZU, M.; TSUHA, O.; KIRISAWA, R.; KAWAKAMI, Y.; IWAI, H. Equid herpesvirus 1 infection in mice. Journal of Veterinary Medicine Science, Tokyo, v. 55, n. 1, p. 119-121, Feb. 1993.

JAIN, N. C. Schalm's veterinary hematology. 4. ed. Philadelphia: Lea \& Febiger. , 1986. $1221 \mathrm{p}$.

KIRISAWA, R.; ENDO, A.; IWAI, H.; KAWAKAMI, Y. Detection and identification of equine herpesvirus-1 and -4 by polymerase chain reaction. Veterinary

Microbiology, Amsterdam, v. 36, n. 1-2, p. 57-67, July 1993. 
KOTAIT, I. Herpesvírus eqüino tipo 1: incidência e diagnóstico laboratorial. Revista Brasileira de Reprodução Animal, Belo Horizonte, v. 1, p. 164-171, 1991.

Suplemento 3.

KOTAIT, I.; PEIXOTO, Z. M. P.; QUEIROZ, L. H.; CUNHA, E. M. S.; SOUZA, M. C. A. M.; MACRUZ, R.; FREITAS, C. A. Diagnóstico laboratorial do aborto eqüino a vírus através de imunofluorescência e soroneutralização. Revista de Microbiologia, São Paulo, v. 20, n. 1, p. 128-132, Jan./Mar. 1989a.

KOTAIT, I.; TOLEDO, C. Z. P.; CUNHA, E. M. S.; SANTOS, O. L.; QUEIROZ, L. H.; PEIXOTO, Z. M. P. Pesquisa de anticorpos anti EHV-1 ("equine herpesvirus type 1") em eqüinos da região de Ribeirão Preto (SP). In: ENCONTRO REGIONAL SUL DE VIROLOGIA: VIROLÓGICA 89, 1., 1989, Florianópolis. Anais... Florianópolis: Sociedade Brasileira de Virologia, 1989b, Resumo 054.

KYDD, J. H.; SMITH, K. C.; HANNANT, D.; LIVESAY, G. J.; MUMFORD, J. A. Distribution of equid herpesvirus-1 (EHV-1) in the respiratory tract of ponies: implications for vaccination strategies. Equine Veterinary Journal, Newmarket, v. 26, n. 6, p. 466-469, Nov. 1994a.

KYDD, J. H.; SMITH, K. C.; HANNANT, D.; LIVESAY, G. J.; MUMFORD, J. A. Distribution of equid herpesvirus-1 (EHV-1) in the respiratory tract associated lymphoid tissue: implications for cellular immunity. Equine Veterinary Journal, Newmarket, v. 26, n. 6, p. 470-473, Nov. 1994b.

KYDD, J.H.; HANNANT, D.; MUMFORD, J.A. Residence and recruitment of leukocytes to the equine lung after EHV-1 infection. Veterinary Immunology and Immunopathology, Amsterdam, v. 52, n. 1-2, p. 15-26, Jun. 1996.

LARA, M. C. C. S. H.; BARROS FILHO, I.; VIANA, F.; GREGORY, L.; CUNHA, E. M. S.; CASTRO, A. F.; BIRGEL, E. H.; FERNANDES, W. R. Pesquisa de anticorpos contra o vírus da arterite dos eqüinos (VAE) e herpes eqüino tipo 1 (HVE-1) em cavalos criados em Curitiba, PR. A Hora Veterinária, Porto Alegre, v. 23, n. 135, p. 26-28, Set.-Out. 2003a.

LARA, M. C. C. S. H.; CUNHA, E. M. S.; NASSAR, A. F. C.; GREGORY, L.; BIRGEL, E. H.; FERNANDES, W. R. Ocorrência do herpesvírus eqüino 1 (HVE-1) em cavalos criados no Estado de São Paulo, Brasil. Ars Veterinária, Jaboticabal, v. 19, n. 3, p. 254-259, 2003b.

LAWRENCE, G. L.; GILKERSON, J.; LOVE, D. N.; SABINE, M.; WHALLEY, J. M. Rapid, single-step differentiation of equid herpesviruses 1 and 4 from clinical material using the polymerase chain reaction and virus-specific primers. Journal of Virological Methods, Amsterdam, v. 47, n. 1-2, p. 59-72, Apr. 1994.

MACKIE, J. T.; MACLEOD, G. A.; REUBEL,G. H.; STUDDERT, M. J. Diagnosis of equine herpesvirus 1 abortion using polymerase chain reaction. Australian

Veterinary Journal, Melbourne, v. 74, n. 5, p. 390-391, Nov. 1996.

MAIR, T. S.; STOKES, C. R.; BOURNE, F. J. Cellular content of secretions obtained by lavage from different levels of the equine respiratory tract. Equine Veterinary Journal, NewMarket, v. 19, n. 5, p. 458-462, Sep. 1987. 
MCCANN, S. H. E.; MUMFORD, J. A.; BINNS, M. M. Development of PCR assays to detect genetic variation amongst equine herpesvirus-1 isolates as an aid to epidemiological investigation. Journal of Virological Methods, Amsterdam. v. 52, n. 1-2, p. 183-194, Mar. 1995.

MCCULLOCH, J.; WILLIAMSON, S. A.; POWIS, S. J.; EDINGTON, N. The effect of EHV-1 infection upon circulating leukocyte populations in the natural equine host. Veterinary Microbiology, Amsterdam, v. 37, n. 1-2, p. 147-161, Oct. 1993.

MCGORUM, B. C.; DIXON, P. M. Evaluation of local endobronchial antigen challenges in the investigation of equine chronic obstructive pulmonary disease. Equine Veterinary Journal, Newmarket, v. 25, n. 4, p. 269-272, July 1993.

MCGORUM, B. C.; DIXON, P. M. The analysis and interpretation of equine bronchoalveolar lavage fluid (BALF) cytology. Equine Veterinary Education, Newmarket, v. 6, n. 4, p. 203-209, 1994.

MCGORUM, B. C.; DIXON, P. M.; HALLIWELL, R. E. W. Responses of horses affected with chronic obstructive pulmonary disease to inhalation challenges with mould antigens. Equine Veterinary Journal, Newmarket, v. 25, n. 4, p. 261-267, July 1993.

MINSON, A. C.; DAVISON, A.; EBERLE, R.; DESROSIERS, R. C.; FLECKENSTEIN, B.; MCGEOCH, D. J.; PELLET, P. E.; ROIZMAN, B; STUDDERT, D. M. J. Family Herpesviridae. In: VAN REGENMORTEL, M. H. V.; FAUQUET, C. M.; BISHOP, D. H. L.; CARSTENS, E. B.; ESTES, M. K.; LEMON, S. M.; MANILOFF, J.; MAYO, M. A.; MCGEOCH, D. J.; PRINGLE, C. R.; WICKNER, R. B. Virus taxonomy: the classification and nomenclature of viruses: the seventh report of the international committee on taxonomy of viruses. San Diego: Academic Press, 2000. p. 203-225.

MODOLO, J. R.; PETZOLDT, K.; GOTTS-CHALK, A. F.; MARGATHO, L. F. F.; FORLIN, W.; CARREIRA, E. L. C. Investigação sorológica do Herpesvirus equi-1 em eqüinos pelo teste de fixação de complemento, considerações sobre seu uso na saúde do haras. A Hora Veterinária, Porto Alegre, v. 8, n. 48, p. 25-27, Mar.-Abr. 1989.

MORI, E. Avaliação da função dos macrófagos alveolares após infecção experimental em cavalos (Equus cabalus - Linnaeus, 1758) por herpesvírus eqüino tipo 1 (HVE-1). 2000. 98 f. Dissertação (Mestrado em Medicina Veterinária) - Faculdade de Medicina Veterinária e Zootecnia, Universidade de São Paulo, São Paulo, 2000.

MORI, E., MORI, C. M. C., FERNANDES, W. R. Avaliação da função de macrófagos alveolares em cavalos clinicamente sadios. Arquivo Brasileiro de Medicina Veterinária e Zootecnia, Belo Horizonte, v. 53, n. 2, p. 172-178, Abr. 2001.

MORI, E; MORI, C. M. C.; DELLA LIBERA, A. M. M. P.; LARA, M. C. C. S. H.; FERNANDES, W. R. Evaluation of equine alveolar macrophage function after experimental infection with equine herpesvirus-1 (EHV-1) in horses. Arquivo Brasileiro de Medicina Veterinária e Zootecnia, Belo Horizonte, v. 55, n. 3, p. 271278, Jun. 2003. 
MULLIS, K. B.; FALOONA, F. A. Specific synthesis of DNA in vitro via polymerasecatalyzed chain reaction. Methods in Enzymology,San Diego, v. 155, p. 335-350, 1987.

MUMFORD, J. A. Equid herpesvirus 1 and 4 infections. In: COETZER, J. A. W; THOMSOM, G. R.; TUSTIN, R. C. Infectious diseases of livestock. Oxford: Oxford University Press, 1994. v. 2, p. 911-925.

MUMFORD, J. A.; ROSSDALE, P. D. Virus and its relationship to the "poor performance" syndrome. Equine Veterinary Journal, Newmarket, v. 12, n. 1, p. 3-9, Jan. 1980.

NATIONAL RESEARCH COUNCIL (NRC). Guide for the Care and Use of Laboratory Animals. Washington D.C: National Academy Press, 1996. 125 p.

NCBI: National Center for Biotechnology Information. Disponível em: <http://www.ncbi.nlm.nih.gov>. Acesso em: 12 jan. 2004.

NICOLSON, L.; CULLINANE, A. A.; ONIONS, D. E. The nucleotide sequence of the equine herpesvirus 4 thymidine kinase gene. Journal of General Virology, Berks, v. 71, n.8, p. 1801-1805, Aug. 1990.

NICOLSON, L.; ONIONS, D. E. The nucleotide sequence of equine herpesvirus $4 \mathrm{gC}$ gene homologue. Virology, Oxford, v. 179, n. 1, p. 378-387, Nov. 1990.

NILSSON, M. R.; CORREAA, W. M. Isolamento do vírus do aborto eqüino no Estado de São Paulo. Arquivos do Instituto Biológico, São Paulo, v. 33, n. 2, p. 23-25, Abr.-Jun. 1966.

NOWOTNY, N.; BURTSCHER, H.; BÜRKI, F. Neuropathogenicity for suckling mice of equine herpesvirus 1 from the Lipizzan outbreak 1983 and of selected other EHV 1 strains. Journal of Veterinary Medicine B, Berlin and Hamburg, v. 34, n. 6, p. 441448, Aug. 1987.

O'KEEFE, J. S.; JULIAN, A.; MORIARTY, K.; MURRAY, A.; WILKS, C. R. A comparison of the polymerase chain reaction with standard laboratory methods for the detection of EHV-1 and EHV-4 in archival tissue samples. New Zealand Veterinary Journal, Wellington, v. 42, n. 3, p. 93-96, June 1994.

O'KEEFE, J. S.; MURRAY, A.; WILKS, C. R.; MORIARTY, K. M. Amplification and differentiation of the DNA of an abortigenic (type 1) and a respiratory (type 4) strain of equine herpesvirus by the polymerase chain reaction. Research in Veterinary Science, London, v. 50, n. 3, p. 349-351, May 1991.

O'NEILL, T.; KYDD, J. H.; ALLEN, G. P.; WATTRANG, E.; MUMFORD, J. A.; HANNANT, D. Determination of equid herpesvirus 1-specific, CD8 ${ }^{+}$, cytotoxic T lymphocyte precursor frequencies in ponies. Veterinary Immunology and Immunopathology, Amsterdam, v. 70, n. 1-2, p. 43-54, Sept. 1999. 
OSTERRIEDER, N.; HÜBERT, P. H.; BRANDMÜLLER, C.; KAADEN, O. -R. A touchdown PCR for the differentiation of equine herpesvirus type 1 (EHV-1) field strains from the modified live vaccine strain $\mathrm{RacH}$. Journal of Virological Methods, Amsterdam, v. 50, n. 1-3, p. 129-136, Dec. 1994.

OSTLUND, E. N. The equine herpesviruses. The Veterinary Clinics of North America Equine Practice, Philadelphia, v. 9, n. 2, p. 283-294, Aug. 1993.

PALFI, V.; CHRISTENSEN, L. S. Analyses of restriction fragment patterns (RFPs) and pathogenicity in baby mice of equine herpesvirus 1 and 4 (EHV-1 and EHV-4) strains circulating in Danish horses. Veterinary Microbiology, Amsterdam, v. 47, n. 1-2, p. 199-204, Nov. 1995.

PATEL, J. R.; EDINGTON, N. The pathogenicity in mice of respiratory, abortion and paresis isolates of equine herpesvirus-1. Veterinary Microbiology, Amsterdam, v. 8, n. 3, p. 301-305, Jun. 1983.

PATEL, J. R.; EDINGTON, N.; MUMFORD, J. A. Variation in cellular tropism between isolates of equine herpesvírus-1 in foals. Archives of Virology, Wein, v. 74, n. 1, p. 41-51, 1982.

PERKINS, G.; AINSWORTH, D. M.; ERB, H. N.; DEL PIERO, F.; MILLER, M.; WILKINS, P. A.; PALMER, J.; FRAZER, M. Clinical, haematological and biochemical findings in foals with neonatal equine herpesvírus-1 infection compared with septic and premature foals. Equine Veterinary Journal, Newmarket, v. 31, n. 5, p. 422426, Sept. 1999.

POWELL, D. G. Equine infections respiratory disease. The Veterinary Record, London, v. 96, n. 2, p. 30-34, Jan. 1975.

POWELL, D. G. Viral respiratory disease of the horse. The Veterinary Clinics of North America Equine Practice, Philadelphia, v. 7, n. 1, p. 27-52, Apr. 1991.

POWELL, D. G.; BURROWS, R.; GOODRIDGE, D. Respiratory viral infections among thoroughbred horses in training during 1972. Equine Veterinary Journal, Newmarket, v. 6, n. 1, p. 19-24, Jan. 1974.

PRICKETT, M. E. The pathology of disease caused by equine herpesvírus 1. In: INTERNATIONAL CONFERENCE ON EQUINE INFECTIOUS DISEASES, 2., 1969, Paris. Proceedings...Basel: S. Karger, 1970, p. 24-33.

RAKER, C. W. The nasopharynx.. In: MANSMANN, R. A.; MCALLISTER, E. S. Equine medicine and surgery. 3. ed. Santa Barbara: American Veterinary Publications, 1982. v. 2, p. 747-757.

REINER, U. R.; DE LUCCA NETO, D.; NILSSON, M. R.; NILSSON, T. T.; KOTAIT, I. Isolamento do vírus do aborto eqüino em Campinas, Estado de São Paulo. In: CONGRESSO BRASILEIRO DE MEDICINA VETERINÁRIA, 13., 1972, Brasília. Anais... Brasília: Sociedade Brasileira de Medicina Veterinária, 1972. p. 283-284. 
REUBEL, G. H.; STUDDERT, M. J. Benefits and limitations of polymerase chain reaction (PCR) in veterinary diagnostic virology. Veterinary Bulletin, Wallingford, v. 68, n. 5, p. 505-516, May 1998.

RIGGIO, M. P.; CULLINANE, A. A.; ONIONS, D. E. Identification and nucleotide sequence of the glycoprotein gB gene of equine herpesvirus 4. Journal of Virology, Washington, v. 63, n. 3, p. 1123-1133, Mar. 1989.

RIMSTAD, E.; EVENSEN, $\varnothing$. The identification of equid herpesvirus 1 in paraffinembedded tissues from aborted fetuses by polymerase chain reaction and immunohistochemistry. Journal of Veterinary Diagnostic Investigation, Turlock, v. 5, n. 2, p. 174-183, Apr. 1993.

RIMSTAD, E.; HYLLSETH, B. Equine herpesviruses 1 and 4: amplification and differentiation by polymerase chain reaction. Acta Veterinaria Scandinavica, Kobenhavn, v. 35, n. 3, p. 303-306, 1994.

ROBERTSON, J. T. Pharynx and larynx. In: BEECH, J. Equine respiratory disorders. Philadelphia: Lea \& Febiger, 1991. p. 331-87.

ROSENFELD, G. Corante pancrômico para hematologia e citologia clínica. Nova combinação dos componentes do May-Grunwald e do Giemsa num só corante de emprego rápido. Memórias do Instituto Butantan, São Paulo, v. 20, p. 329-334, Dez. 1947.

SAIKI, R. K.; GELFAND, D. H.; STOFFEL, S.; SCHARF, S. J.; HIGUCHI, R.; HORN, G. T.; MULLIS, K. B.; ERLICH, H. A. Primer-directed enzymatic amplification of DNA with thermostable DNA polymerase. Science, Wasington, v. 239, n. 4839, p. 487491, Jan. 1988.

SAMBROOK, J.; FRITSCH, E. F.; MANIATS, T. Molecular Cloning: a laboratory manual. 2 ed. New York: Cold Spring Harbor Laboratory Press, 1989, 957 p.

SAXEGAARD, F. Isolation and identification of equine rhinopneumonitis virus (equine abortion virus) from causes of abortion and paralysis. Nordisk Veterinaer Medicin, v. 18 , p. 504-512, Nov. 1966.

SCOTT, J. C.; DUTTA, S. K.; MYRUP, A. C. In vivo harboring of equine herpesvirus1 in leukocyte populations and subpopulations and their quantitation from experimentally infected ponies. American Journal Veterinary Research, Schaumburg, v. 44, n. 7, p. 1344-1348, July 1983.

SHARMA, P. C.; CULLINANE, A. A.; ONIONS, D. E.; NICOLSON, L. Diagnosis of equid herpesviruses- 1 and -4 by polymerase chain reaction. Equine Veterinary Journal, Newmarket, v. 24, n. 1, p. 20-25, Jan. 1992.

SLATER, J. Equine herpesvirus-1: immunity in lytic and latent infections. In: WORKSHOP ON EQUINE IMMUNOLOGY. 2001, Santa Fé.

Proceedings...Newmarket: R \& W Publications Limited, 2001. p. 14-16. 
SLATER, J. D.; BORCHERS, K.; THACKRAY, A. M.; FIELD, H. J. The trigeminal ganglion is a location for equine herpesvirus 1 latency and reactivation in the horse. Journal of General Virology, Berks, v. 75, n. 8, p. 2007-2016, Aug. 1994.

SLATER, J. D.; GIBSON, J. S.; FIELD, H. J. Pathogenicity of thymidine kinasedeficient mutant of equine herpesvirus 1 in mice and specific pathogen-free foals. Journal of General Virology, Berks, v. 74, n. 5, p. 819-828, May 1993.

SPEIRS, V. C. Clinical examination of horses. Philadelphia: W. B. Saunders Company, 1997. 358 p.

STOKES, A.; CORTEYN, A. H.; MURRAY, P. K. Clinical signs and humoral immune response in horses following equine herpesvirus type-1 infection and their susceptibility to equine herpesvirus type-4 challenge. Research in Veterinary Science, London, v. 51, n. 2, p. 141-8, Sep. 1991.

STUDDERT, M. J.; HARTLEY, C. A.; DYNON, K.; SANDY, J. R.; SLOCOMBE, R. F.; CHARLES, J. A.; MILNE, M. E.; CLARKE, A. F.; EL-HAGE, C. Outbreak of equine herpesvirus type 1 myeloencephalitis: new insights from virus identification by PCR and the application of an EHV-1-specific antibody detection ELISA. The Veterinary Record, London, v. 153, n. 14, p. 417-423, Oct. 2003.

STUDDERT, M. J.; SIMPSON, T.; ROIZMAN, B. Differentiation of respiratory and abortigenic isolates of equine herpesvírus 1 by restriction endonucleases. Science, Washington v. 214, n. 4520, p. 562-564, Oct. 1981.

SUTTON, G.A.; VIEL, L.; CARMAN, P.S.; BOAG, B.L. Pathogenesis and clinical signs of equine herpesvirus-1 in experimentally infected ponies in vivo. Canadian Journal Veterinary Research, Ottawa, v. 62, n. 1, p. 49-55, Jan. 1998.

SWEENEY, C. R.; BEECH, J. Bronchoalveolar lavage. In: BEECH, J. Equine respiratory disorders. Philadelphia: Lea \& Febiger, 1991. p. 55-61.

SWEENEY, C. R.; ROSSIER, Y.; ZIEMER, E. L.; LINDBORG, S. Effects of prior lavage on bronchoalveolar lavage fluid cell population of lavaged and unlavaged lung segments in horses. American Journal Veterinary Research, Schaumburg, v. 55, n. 11, p. 1501-1505, Nov. 1994.

TANIGUCHI, A.; FUKUSHI, H.; MATSUMURA, T.; YANAI, T.; MASEGI, T.; HIRAI, K. Pathogenicity of new neurotropic equine herpesvirus 9 (gazelle herpesvirus 1 ) in horses. Journal of Veterinary Medicine Science, Tokyo, v. 62, n. 2, p. 215-218, Feb. 2000.

TAOUJI, S.; COLLOBERT, C.; GICQUEL, B.; SAILLEAU, C.; BRISSEAU, N.; MOUSSU, C.; BREUIL, M. -F.; PRONOST, S.; BORCHERS, K.; ZIENTARA, S. Detection and isolation of equine herpesviruses 1 and 4 from horses in Normandy: an autopsy study of tissue distribution in relation to vaccination status. Journal of Veterinary Medicine B, Berlin, v. 49, n. 8, p. 394-399, Oct. 2002.

TELFORD, E. A., WATSON, M. S., MCBRIDE, K.; DAVISON, A. J. The DNA sequence of equine herpesvirus-1. Virology, Oxford, v. 189, n. 1, p. 304-316, July 1992. 
TELFORD, E. A., WATSON, M. S., PERRY, J.; CULLINANE, A. A.; DAVISON, A. J. The DNA sequence of equine herpesvirus-4. Journal of General Virology, Berks, v. 79, n. 5, p. 1197-1203, May 1998.

THOMSON, G. R.; MUMFORD, J. A.; CAMPBELL, J.; GRIFFITHS, L.; CLAPHAM, P. Serological detection of equid herpesvírus 1 infections of the respiratory tract.

Equine Veterinary Journal, Newmarket, v. 8, n. 2, p. 58-65, Apr. 1976.

TRAUB-DARGATZ, J. L.; MCKINNON, A. O.; BRUYNINCKX, W. J.; THRALL, M. A.; JONES, R. L.; BLANCQUAERT, A. -M. B. Effect of transportation stress on bronchoalveolar lavage fluid analysis in female horses. American Journal Veterinary Research, Schaumburg, v. 49, n. 7, p. 1026-1029, July 1988.

TREMBLAY, G. M.; FERLAND, C.; LAPOINTE, J. -M.; VRINS, A.; LAVOIE, J. P.; CORMIER, Y. Effect of stabling on bronchoalveolar cells obtained from normal and COPD horses. Equine Veterinary Journal, Newmarket, v. 25, n. 3, p. 194-197, May 1993.

VAN MAANEN, C. Equine herpesvirus 1 and 4 infectious: an update. The Veterinary Quarterly, Utrecht, v. 24, n. 2, p. 57-78, June 2002.

VAN MAANEN, C.; WILLINK, D. L.; SMEENK, L. A. J.; BRINKHOF, J.; TERPSTRA, C. An equine herpesvirus 1 (EHV1) abortion storm at a riding school. The Veterinary Quarterly, Utrecht, v. 22, n. 2, p. 83-87, Apr. 2000.

VAN WOENSEL, P. A. M.; GOOVAERTS, D.; MARKX, D.; VISSER, N. A mouse model for testing the pathogenicity of equine herpes virus-1 strains. Journal of Virological Methods, Amsterdam, v. 54, n. 1, p. 39-49, Jul. 1995.

VARASSO, A.; DYNON, K.; FICORILLI, N.; HARTLEY, C. A.; STUDDERT, M. J.; DRUMMER, $H$. E. Identification of equine herpesviruses 1 and 4 by polymerase chain reaction. Australian Veterinary Journal, Melbourne, v. 79, n. 8, p. 563-569, Aug. 2001.

VARGAS, A. C.; WEIBLEN R. Prevalência de anticorpos contra herpesvírus eqüino tipo 1 (HVE 1) em eqüinos de alguns municípios do Estado do Rio Grande do Sul. A Hora Veterinária, Porto Alegre, v. 10, n. 59, p. 5-8, Jan.-Fev., 1991.

VASCONCELLOS, L.A.S. Correlação entre abortamento eqüino e os níveis de anticorpos séricos para Leptospira interrogans, Leptospira biflexa e herpesvírus eqüino tipo 1. 1992. 50 f. Dissertação (Mestrado em Medicina Veterinária) - Faculdade de Medicina Veterinária e Zootecnia, Universidade de São Paulo, São Paulo, 1992.

VIEL, L.; HEWSON, J. Bronchoalveolar lavage. In: ROBINSON, N. E. Current Therapy Equine Medicine. 5. ed. Philadelphia: W.B. Saunders, 2003, p. 407-411.

WAGNER, W. N.; BOGDAN, J.; HAINES, D.; TOWNSEND, H. G. G.; MISRA, V. Detection of equine herpesvirus and differentiation of equine herpesvirus type 1 from 4 by the polymerase chain reaction. Canadian Journal of Microbiology, Ottawa, v. 38, n. 11, p. 1193-1196, Nov. 1992. 
WALKER, C.; LOVE, D. N.; WHALLEY, J. M. Comparison of the pathogenesis of acute equine herpesvírus $1(E H V-1)$ infection in the horse and the mouse model: a review. Veterinary Microbiology, Amsterdam, v. 68, n. 1-2, p. 3-13, Aug. 1999.

WALKER, C.; PACKIARAJAH, P.; GILKERSON, J. R.; LOVE, D. N.; WHALLEY, J. $M$. Primary and challenge infection of mice with equine herpesvirus 1, strain HSV25A. Virus Research, Amsterdam, v. 57, n. 2, p. 151-162, Oct. 1998.

WELCH, H. M.; BRIDGES, C. G.; LYON, A. M.; GRIFFITHS, L.; EDINGTON, N. Latent equid herpesviruses 1 and 4 : detection and distinction using the polymerase chain reaction and co-cultivation from lymphoid tissues. Journal of General Virology, Berks, v. 73, n. 2, p. 261-268, Feb. 1992.

WILCOX, G. E.; RAIDAL, S. Role of viruses in respiratory disease. Rural Industries Research \& Development Corporation, 2000. Disponível em: <http://www.rirdc.gov.au/reports/Index.htm>. Acesso em: 09 nov. 2002.]

WONG, C. W.; THOMPSON, H. L.; THONG, Y. H.; THORNTON, J. R. Effect of strenuous exercise stress on chemiluminescence response of equine alveolar macrophages. Equine Veterinary Journal, Newmarket, v. 22, n. 1, p. 33-35, Jan. 1990.

ZINKL, J. G. The lower respiratory tract. In: COWELL, R. L.; TYLER, R. D. Cytology and hematology of the horse. St. Louis: The C.V. Mosby Company, 1992. p. 77-87. 


\section{Apêndices}


APÊNDICE A - Variação da temperatura corpórea $\left({ }^{\circ} \mathrm{C}\right)$ matutina de cavalos dos grupos experimentais I e II, durante o período de 10 dias após a inoculação com o herpesvírus eqüino tipo 1 (HVE-1). São Paulo, 2004

\begin{tabular}{|c|c|c|c|c|c|c|c|c|c|c|}
\hline \multicolumn{11}{|c|}{ Temperatura Corpórea $\left({ }^{\circ} \mathrm{C}\right)$ Matutina } \\
\hline \multirow[b]{2}{*}{$\begin{array}{c}\text { Dias pós- } \\
\text { inoculação }\end{array}$} & \multicolumn{5}{|c|}{ Grupo I } & \multicolumn{5}{|c|}{ Grupo II } \\
\hline & 01 & 02 & 03 & 04 & 05 & 06 & 07 & 08 & 09 & 10 \\
\hline 0 & 36,2 & 37,1 & 36,8 & 37,1 & 36,8 & 36,2 & 36,9 & 37,0 & 36,2 & 36,5 \\
\hline 01 & 36,9 & 37,4 & 36,8 & 37,6 & 37,5 & 36,7 & 36,8 & 36,8 & 36,9 & 36,8 \\
\hline 02 & 37,2 & 37,7 & 37,3 & 37,4 & 37,2 & 35,8 & 37,0 & 36,8 & 36,5 & 36,7 \\
\hline 03 & 37,0 & 37,4 & 36,8 & 37,6 & 37,0 & 36,1 & 36,1 & 36,5 & 35,9 & 36,7 \\
\hline 04 & 37,2 & 37,3 & 37,5 & 37,4 & 36,8 & 36,0 & 36,5 & 36,9 & 36,3 & 36,3 \\
\hline 05 & 36,8 & 37,4 & 37,3 & 37,3 & 37,6 & 37,0 & 37,4 & 37,1 & 35,4 & 36,8 \\
\hline 06 & 36,8 & 37,0 & 36,5 & 37,3 & 37,1 & 36,8 & 36,4 & 36,7 & 36,7 & 36,6 \\
\hline 07 & 36,8 & 37,0 & 36,4 & 37,3 & 37,0 & 36,3 & 36,3 & 36,9 & 36,3 & 36,2 \\
\hline 08 & 36,9 & 37,4 & 36,5 & 37,2 & 37,1 & 36,3 & 36,7 & 36,4 & 36,8 & 36,5 \\
\hline 09 & 36,4 & 36,7 & 36,4 & 37,1 & 36,9 & 35,9 & 36,2 & 36,9 & 36,4 & 36,5 \\
\hline 10 & 37,1 & 37,3 & 37,0 & 37,3 & 37,3 & 36,2 & 36,7 & 36,7 & 36,4 & 36,6 \\
\hline
\end{tabular}


APÊNDICE B - Variação da temperatura corpórea $\left({ }^{\circ} \mathrm{C}\right)$ vespertina de cavalos dos grupos experimentais I e II inoculados com o herpesvírus eqüino tipo 1 (HVE-1). São Paulo, 2004

\begin{tabular}{|c|c|c|c|c|c|c|c|c|c|c|}
\hline \multicolumn{11}{|c|}{ Temperatura Corpórea $\left({ }^{\circ} \mathrm{C}\right)$ Vespertina } \\
\hline \multirow[b]{2}{*}{$\begin{array}{l}\text { Dias pós- } \\
\text { inoculação }\end{array}$} & \multicolumn{5}{|c|}{ Grupo I } & \multicolumn{5}{|c|}{ Grupo II } \\
\hline & 01 & 02 & 03 & 04 & 05 & 06 & 07 & 08 & 09 & 10 \\
\hline 0 & 37,2 & 38,2 & 38,2 & 37,3 & 37,3 & 36,9 & 37,3 & 37,2 & 36,6 & 37,4 \\
\hline 01 & 37,6 & 38,0 & 37,8 & 37,5 & 37,2 & 36,4 & 37,6 & 37,3 & 36,8 & 36,9 \\
\hline 02 & 37,2 & 38,1 & 37,6 & 37,5 & 37,4 & 36,8 & 37,1 & 37,1 & 36,7 & 36,8 \\
\hline 03 & 37,3 & 37,8 & 37,8 & 38,0 & 37,4 & 37,4 & 37,4 & 37,8 & 37,6 & 37,6 \\
\hline 04 & 37,8 & 37,8 & 38,0 & 37,7 & 37,4 & 37,3 & 37,3 & 37,4 & 36,3 & 37,2 \\
\hline 05 & 37,3 & 38,0 & 38,1 & 37,8 & 37,8 & 36,7 & 36,6 & 36,9 & 36,6 & 37,0 \\
\hline 06 & 37,4 & 38,1 & 37,8 & 37,4 & 37,6 & 37,1 & 36,9 & 37,2 & 36,6 & 37,5 \\
\hline 07 & 37,6 & 37,8 & 37,8 & 37,8 & 37,2 & 37,1 & 36,7 & 37,3 & 36,9 & 37,0 \\
\hline 08 & 37,8 & 38,2 & 37,0 & 37,9 & 37,5 & 37,0 & 37,0 & 37,4 & 37,2 & 36,9 \\
\hline 09 & 37,7 & 37,8 & 37,8 & 37,8 & 37,5 & 36,9 & 36,9 & 37,4 & 36,9 & 37,2 \\
\hline 10 & 37,8 & 38,2 & 37,8 & 38,2 & 37,6 & 37,5 & 37,2 & 37,3 & 37,6 & 37,2 \\
\hline
\end{tabular}


APÊNDICE C - Contagem total do número de hemácias sangüíneas de cavalos dos grupos experimentais I e II inoculados com o herpesvírus eqüino tipo 1 (HVE-1). Os resultados foram expressos em número de células $/ \mathrm{mm}^{3}$. São Paulo, 2004

\begin{tabular}{|c|c|c|c|c|c|c|c|c|c|c|}
\hline \multicolumn{11}{|c|}{ Número de Hemácias Sangüíneas $\left(\times 10^{6} / \mathrm{mm}^{3}\right)$} \\
\hline \multirow[b]{2}{*}{$\begin{array}{l}\text { Dias pós- } \\
\text { inoculação }\end{array}$} & \multicolumn{5}{|c|}{ Grupo I } & \multicolumn{5}{|c|}{ Grupo II } \\
\hline & 01 & 02 & 03 & 04 & 05 & 06 & 07 & 08 & 09 & 10 \\
\hline 0 & 8,08 & 8,14 & 7,93 & 8,20 & 8,07 & 8,17 & 7,98 & 9,93 & 7,24 & 7,87 \\
\hline 01 & 7,71 & 7,47 & 7,57 & 8,21 & 8,81 & 8,05 & 7,82 & 8,75 & 6,68 & 7,49 \\
\hline 02 & 7,49 & 8,62 & 8,14 & 7,58 & 7,79 & 8,82 & 7,08 & 8,59 & 6,19 & 7,48 \\
\hline 03 & 8,18 & 7,22 & 8,10 & 8,76 & 7,86 & 9,29 & 8,24 & 11,03 & 7,08 & 9,54 \\
\hline 04 & 7,28 & 8,45 & 7,98 & 7,37 & 8,22 & 8,97 & 7,79 & 10,36 & 6,78 & 8,68 \\
\hline 05 & 7,56 & 8,44 & 7,48 & 7,52 & 8,10 & 8,40 & 4,92 & 8,08 & 6,30 & 7,40 \\
\hline 06 & 7,39 & 7,51 & 8,16 & 8,00 & 8,34 & 7,68 & 6,54 & 8,28 & 6,36 & 7,36 \\
\hline 07 & 7,76 & 6,83 & 8,38 & 7,45 & 7,93 & 8,06 & 7,17 & 10,14 & 6,54 & 8,39 \\
\hline 08 & 7,04 & 7,00 & 7,39 & 7,78 & 7,81 & 8,86 & 6,05 & 11,51 & 6,34 & 7,61 \\
\hline 09 & 7,29 & 7,74 & 7,74 & 7,64 & 8,18 & 8,84 & 6,75 & 8,55 & 6,48 & 8,21 \\
\hline 10 & 6,74 & 6,91 & 7,20 & 7,26 & 7,43 & 8,99 & 5,94 & 8,33 & 6,31 & 7,13 \\
\hline
\end{tabular}


APÊNDICE D- Volume globular sangüíneo de cavalos dos grupos experimentais I e II inoculados com o herpesvírus eqüino tipo 1 (HVE-1). Os resultados foram expressos em \%. São Paulo, 2004

\begin{tabular}{|c|c|c|c|c|c|c|c|c|c|c|}
\hline \multicolumn{11}{|c|}{ Volume Globular Sangüíneo (\%) } \\
\hline \multirow[b]{2}{*}{$\begin{array}{l}\text { Dias pós- } \\
\text { inoculação }\end{array}$} & \multicolumn{5}{|c|}{ Grupo I } & \multicolumn{5}{|c|}{ Grupo II } \\
\hline & 01 & 02 & 03 & 04 & 05 & 06 & 07 & 08 & 09 & 10 \\
\hline 0 & 37,0 & 34,0 & 34,0 & 33,0 & 35,0 & 37,0 & 39,0 & 43,0 & 37,0 & 33,0 \\
\hline 01 & 36,0 & 32,0 & 32,0 & 33,0 & 38,0 & 37,0 & 37,0 & 39,0 & 34,0 & 34,0 \\
\hline 02 & 33,0 & 34,0 & 34,0 & 36,0 & 34,0 & 40,0 & 37,0 & 38,0 & 30,0 & 34,0 \\
\hline 03 & 37,0 & 31,0 & 34,0 & 36,0 & 34,0 & 38,0 & 35,0 & 41,0 & 30,0 & 34,0 \\
\hline 04 & 31,0 & 34,0 & 34,0 & 30,0 & 35,0 & 37,0 & 32,0 & 38,0 & 28,0 & 32,0 \\
\hline 05 & 36,0 & 36,0 & 31,0 & 32,0 & 34,0 & 38,0 & 32,0 & 37,0 & 34,0 & 36,0 \\
\hline 06 & 34,0 & 30,0 & 33,0 & 33,0 & 36,0 & 38,0 & 36,0 & 42,0 & 35,0 & 37,0 \\
\hline 07 & 35,0 & 31,0 & 36,0 & 32,0 & 36,0 & 37,0 & 37,0 & 44,0 & 33,0 & 36,0 \\
\hline 08 & 32,0 & 33,0 & 30,0 & 33,0 & 33,0 & 37,0 & 30,0 & 33,0 & 30,0 & 34,0 \\
\hline 09 & 33,0 & 33,0 & 33,0 & 32,0 & 36,0 & 38,0 & 35,0 & 38,0 & 30,0 & 35,0 \\
\hline 10 & 30,0 & 30,0 & 31,0 & 29,0 & 33,0 & 37,0 & 33,0 & 34,0 & 30,0 & 32,0 \\
\hline
\end{tabular}


APÊNDICE E -Taxa de hemoglobina sangüínea de cavalos dos grupos experimentais I e II inoculados com o herpesvírus eqüino tipo 1 (HVE-1). Os resultados foram expressos em g/dl. São Paulo, 2004

\begin{tabular}{|c|c|c|c|c|c|c|c|c|c|c|}
\hline \multirow[b]{3}{*}{$\begin{array}{l}\text { Dias pós- } \\
\text { inoculação }\end{array}$} & \multicolumn{9}{|c|}{ Taxa de hemoglobina sangüínea (g/dl) } & \\
\hline & \multicolumn{5}{|c|}{ Grupo I } & \multicolumn{5}{|c|}{ Grupo II } \\
\hline & 01 & 02 & 03 & 04 & 05 & 06 & 07 & 08 & 09 & 10 \\
\hline 0 & 13,4 & 12,5 & 12,2 & 11,9 & 12,4 & 12,6 & 14,3 & 15,4 & 13,0 & 11,8 \\
\hline 01 & 12,9 & 11,7 & 11,7 & 12,1 & 13,5 & 12,9 & 13,2 & 13,7 & 12,1 & 11,5 \\
\hline 02 & 12,0 & 12,9 & 12,0 & 12,8 & 12,0 & 13,9 & 12,6 & 13,7 & 10,7 & 12,1 \\
\hline 03 & 13,4 & 11,1 & 12,4 & 12,6 & 12,0 & 12,9 & 12,7 & 15,0 & 11,2 & 12,9 \\
\hline 04 & 11,5 & 12,6 & 12,0 & 10,6 & 12,7 & 12,8 & 12,6 & 14,2 & 11,0 & 12,3 \\
\hline 05 & 12,3 & 13,0 & 11,6 & 11,1 & 12,6 & 13,2 & 9,1 & 12,8 & 11,9 & 11,9 \\
\hline 06 & 12,3 & 11,4 & 12,3 & 11,6 & 12,9 & 12,5 & 11,6 & 13,4 & 11,6 & 11,8 \\
\hline 07 & 13,0 & 10,9 & 13,0 & 11,0 & 12,4 & 13,3 & 12,9 & 16,0 & 12,4 & 12,9 \\
\hline 08 & 11,4 & 10,4 & 11,0 & 11,3 & 11,7 & 14,4 & 11,1 & 17,1 & 10,9 & 11,8 \\
\hline 09 & 12,4 & 12,1 & 12,1 & 11,2 & 12,4 & 13,4 & 11,8 & 12,9 & 11,3 & 12,1 \\
\hline 10 & 10,9 & 10,4 & 10,9 & 10,5 & 11,2 & 13,5 & 11,0 & 12,4 & 10,8 & 10,9 \\
\hline
\end{tabular}


APÊNDICE F - Volume corpuscular médio (VCM), calculado a partir do volume globular e número de hemácias sangüíneas, de cavalos dos grupos experimentais I e II inoculados com o herpesvírus eqüino tipo 1 (HVE-1). Os resultados foram expressos em fl. São Paulo, 2004

\begin{tabular}{|c|c|c|c|c|c|c|c|c|c|c|}
\hline \multicolumn{11}{|c|}{ Volume Corpuscular Médio (fl) } \\
\hline \multirow[b]{2}{*}{$\begin{array}{l}\text { Dias pós- } \\
\text { inoculação }\end{array}$} & \multicolumn{5}{|c|}{ Grupo I } & \multicolumn{5}{|c|}{ Grupo II } \\
\hline & 01 & 02 & 03 & 04 & 05 & 06 & 07 & 08 & 09 & 10 \\
\hline 0 & 45,8 & 41,8 & 42,9 & 40,2 & 43,4 & 45,3 & 48,9 & 43,3 & 51,1 & 41,9 \\
\hline 01 & 46,7 & 42,8 & 42,3 & 40,2 & 43,1 & 46,0 & 47,3 & 44,6 & 50,9 & 45,4 \\
\hline 02 & 44,1 & 39,4 & 41,8 & 47,5 & 43,6 & 45,4 & 52,3 & 44,2 & 48,5 & 45,5 \\
\hline 03 & 45,2 & 42,9 & 42,0 & 41,1 & 43,3 & 40,9 & 42,5 & 37,2 & 42,4 & 35,6 \\
\hline 04 & 42,6 & 40,2 & 42,6 & 40,7 & 42,6 & 41,2 & 41,1 & 36,7 & 41,3 & 36,9 \\
\hline 05 & 47,6 & 42,7 & 41,4 & 42,6 & 42,0 & 45,2 & 65,0 & 45,8 & 54,0 & 48,6 \\
\hline 06 & 46,0 & 39,9 & 40,4 & 41,3 & 43,2 & 49,5 & 55,0 & 50,7 & 55,0 & 50,3 \\
\hline 07 & 45,1 & 45,4 & 43,0 & 43,0 & 45,4 & 45,9 & 51,6 & 43,4 & 50,5 & 42,9 \\
\hline 08 & 45,5 & 47,1 & 40,6 & 42,4 & 42,3 & 41,8 & 49,6 & 28,7 & 47,3 & 44,7 \\
\hline 09 & 45,3 & 42,6 & 42,6 & 41,9 & 44,0 & 43,0 & 51,9 & 44,4 & 46,3 & 42,6 \\
\hline 10 & 44,5 & 43,4 & 43,1 & 39,9 & 44,4 & 41,2 & 55,6 & 40,8 & 47,5 & 44,9 \\
\hline
\end{tabular}


APÊNDICE G - Hemoglobina corpuscular média (HCM), calculado a partir da taxa de hemoglobina e número de hemácias sangüíneas, de cavalos dos grupos experimentais I e II inoculados com o herpesvírus eqüino tipo 1 (HVE-1). Os resultados foram expressos em pg. São Paulo, 2004

\begin{tabular}{|c|c|c|c|c|c|c|c|c|c|c|}
\hline \multirow[b]{3}{*}{$\begin{array}{l}\text { Dias pós- } \\
\text { inoculação }\end{array}$} & \multicolumn{9}{|c|}{ Hemoglobina Corpuscular Média (pg) } & \\
\hline & \multicolumn{5}{|c|}{ Grupo I } & \multicolumn{5}{|c|}{ Grupo II } \\
\hline & 01 & 02 & 03 & 04 & 05 & 06 & 07 & 08 & 09 & 10 \\
\hline 0 & 16,6 & 15,4 & 15,4 & 14,5 & 15,4 & 15,4 & 17,9 & 15,5 & 18,0 & 15,0 \\
\hline 01 & 16,7 & 15,7 & 15,5 & 14,7 & 15,3 & 16,0 & 16,9 & 15,7 & 18,1 & 15,4 \\
\hline 02 & 16,0 & 15,0 & 14,7 & 16,9 & 15,4 & 15,8 & 17,8 & 15,9 & 17,3 & 16,2 \\
\hline 03 & 16,4 & 15,4 & 15,3 & 14,4 & 15,3 & 13,9 & 15,4 & 13,6 & 15,8 & 13,5 \\
\hline 04 & 15,8 & 14,9 & 15,0 & 14,4 & 15,5 & 14,3 & 16,2 & 13,7 & 16,2 & 14,2 \\
\hline 05 & 16,3 & 15,4 & 15,5 & 14,8 & 15,6 & 15,7 & 18,5 & 15,8 & 18,9 & 16,1 \\
\hline 06 & 16,6 & 15,2 & 15,1 & 14,5 & 15,5 & 16,3 & 17,7 & 16,2 & 18,2 & 16,0 \\
\hline 07 & 16,8 & 16,0 & 15,5 & 14,8 & 15,6 & 16,5 & 18,0 & 15,8 & 19,0 & 15,4 \\
\hline 08 & 16,2 & 14,9 & 14,9 & 14,5 & 15,0 & 16,3 & 18,3 & 14,9 & 17,2 & 15,5 \\
\hline 09 & 17,0 & 15,6 & 15,6 & 14,7 & 15,2 & 15,2 & 17,5 & 15,1 & 17,4 & 14,7 \\
\hline 10 & 16,2 & 15,1 & 15,1 & 14,5 & 15,1 & 15,0 & 18,5 & 14,9 & 17,1 & 15,3 \\
\hline
\end{tabular}


APÊNDICE H - Concentração de hemoglobina corpuscular média (CHCM), calculado a partir da taxa de hemoglobina e volume globular sangüíneos, de cavalos dos grupos experimentais I e II inoculados com o herpesvírus eqüino tipo 1 (HVE-1). Os resultados foram expressos em g/dl. São Paulo, 2004

\begin{tabular}{|c|c|c|c|c|c|c|c|c|c|c|}
\hline \multicolumn{11}{|c|}{ Concentração de Hemoglobina Corpuscular Média (g/dl) } \\
\hline \multirow[b]{2}{*}{$\begin{array}{l}\text { Dias pós- } \\
\text { inoculação }\end{array}$} & \multicolumn{5}{|c|}{ Grupo I } & \multicolumn{5}{|c|}{ Grupo II } \\
\hline & 01 & 02 & 03 & 04 & 05 & 06 & 07 & 08 & 09 & 10 \\
\hline 0 & 36,2 & 36,8 & 35,9 & 36,1 & 35,4 & 34,1 & 36,7 & 35,8 & 35,1 & 35,8 \\
\hline 01 & 35,8 & 36,6 & 36,6 & 36,7 & 35,5 & 34,9 & 35,7 & 35,1 & 35,6 & 33,8 \\
\hline 02 & 36,4 & 37,9 & 35,3 & 35,6 & 35,3 & 34,8 & 34,1 & 36,1 & 35,7 & 35,6 \\
\hline 03 & 36,2 & 35,8 & 36,5 & 35,0 & 35,3 & 33,9 & 36,3 & 36,6 & 37,3 & 37,9 \\
\hline 04 & 37,1 & 37,1 & 35,3 & 35,3 & 36,3 & 34,6 & 39,4 & 37,4 & 39,3 & 38,4 \\
\hline 05 & 34,2 & 36,1 & 37,4 & 34,7 & 37,1 & 34,7 & 28,4 & 34,6 & 35,0 & 33,1 \\
\hline 06 & 36,2 & 38,0 & 37,3 & 35,2 & 35,8 & 32,9 & 32,2 & 31,9 & 33,1 & 31,9 \\
\hline 07 & 37,1 & 35,2 & 36,1 & 34,4 & 34,4 & 35,9 & 34,9 & 36,4 & 37,6 & 35,8 \\
\hline 08 & 35,6 & 31,5 & 36,7 & 34,2 & 35,5 & 38,9 & 37,0 & 51,8 & 36,3 & 34,7 \\
\hline 09 & 37,6 & 36,7 & 36,7 & 35,0 & 34,4 & 35,3 & 33,7 & 33,9 & 37,7 & 34,6 \\
\hline 10 & 36,3 & 34,7 & 35,2 & 36,2 & 33,9 & 36,5 & 33,3 & 36,5 & 36,0 & 34,1 \\
\hline
\end{tabular}


APÊNDICE I - Títulos de anticorpos soroneutralizantes contra o herpesvírus eqüino tipo 1 (HVE-1) em soros sangüíneos de cavalos dos grupos experimentais I e II. São Paulo, 2004

\begin{tabular}{|c|c|c|c|c|c|c|c|c|c|c|}
\hline \multicolumn{11}{|c|}{ Títulos de Anticorpos } \\
\hline \multirow[b]{2}{*}{$\begin{array}{l}\text { Dias pós- } \\
\text { inoculação }\end{array}$} & \multicolumn{5}{|c|}{ Grupo I } & \multicolumn{5}{|c|}{ Grupo II } \\
\hline & 01 & 02 & 03 & 04 & 05 & 06 & 07 & 08 & 09 & 10 \\
\hline-21 & - & - & - & - & - & 64 & 16 & 32 & 32 & - \\
\hline-14 & 16 & 0 & 4 & 8 & 8 & 64 & 8 & 16 & 16 & 16 \\
\hline 0 & 8 & 0 & 4 & 8 & 16 & 256 & 8 & 32 & 32 & 8 \\
\hline+07 & 8 & 0 & 8 & 16 & 8 & 512 & 8 & 64 & 64 & 8 \\
\hline+14 & 32 & 4 & 128 & 32 & 8 & 512 & 16 & 64 & 512 & 64 \\
\hline+21 & 16 & 4 & 128 & 8 & 16 & 256 & 32 & 128 & 128 & 16 \\
\hline+28 & 8 & 8 & 64 & 32 & 16 & 512 & 16 & 64 & 64 & 16 \\
\hline
\end{tabular}


APÊNDICE J - Concentração de DNA no LBA (ng/ $\mu$ l) de cavalos dos grupos experimentais I e II. Grau de pureza do DNA (razão $A_{260} / A_{280}$ ) entre parênteses. São Paulo, 2004

\begin{tabular}{|c|c|c|c|c|c|c|}
\hline & \multicolumn{6}{|c|}{ Concentração de DNA no LBA (ng/ $\mu \mathrm{l})$} \\
\hline \multirow[t]{2}{*}{ Animal } & \multicolumn{6}{|c|}{ Dias pós-inoculação } \\
\hline & -07 & +02 & +09 & +16 & +23 & +30 \\
\hline 01 & $\begin{array}{c}223,20 \\
(2,32)\end{array}$ & $\begin{array}{l}379,0 \\
(1,81)\end{array}$ & $\begin{array}{l}714,0 \\
(1,85)\end{array}$ & $\begin{array}{l}562,0 \\
(1,78)\end{array}$ & $\begin{array}{l}412,0 \\
(1,85)\end{array}$ & $\begin{array}{c}142,0 \\
(1,80)\end{array}$ \\
\hline 02 & $\begin{array}{c}338,30 \\
(2,14)\end{array}$ & $\begin{array}{l}227,0 \\
(1,73)\end{array}$ & $\begin{array}{c}1013,0 \\
(1,84)\end{array}$ & $\begin{array}{l}332,0 \\
(1,84)\end{array}$ & $\begin{array}{l}251,0 \\
(1,84)\end{array}$ & $\begin{array}{l}292,0 \\
(1,85)\end{array}$ \\
\hline 03 & $\begin{array}{c}335,60 \\
(2,20)\end{array}$ & $\begin{array}{l}428,0 \\
(1,81)\end{array}$ & $\begin{array}{l}236,0 \\
(1,88)\end{array}$ & $\begin{array}{c}1637,0 \\
(1,86)\end{array}$ & $\begin{array}{l}545,0 \\
(1,82)\end{array}$ & $\begin{array}{l}252,6 \\
(2,48)\end{array}$ \\
\hline 04 & $\begin{array}{c}180,90 \\
(2,83)\end{array}$ & $\begin{array}{l}194,0 \\
(1,91)\end{array}$ & $\begin{array}{r}177,0 \\
(1,89)\end{array}$ & $\begin{array}{l}444,0 \\
(1,86)\end{array}$ & $\begin{array}{l}431,0 \\
(1,87)\end{array}$ & $\begin{array}{r}193,0 \\
(1,84)\end{array}$ \\
\hline 05 & $\begin{array}{c}105,90 \\
(3,36)\end{array}$ & $\begin{array}{l}349,0 \\
(1,74)\end{array}$ & $\begin{array}{l}308,0 \\
(1,73)\end{array}$ & $\begin{array}{l}523,0 \\
(1,84)\end{array}$ & $\begin{array}{l}361,0 \\
(1,88)\end{array}$ & $\begin{array}{l}418,0 \\
(1,79)\end{array}$ \\
\hline 06 & $\begin{array}{l}268,0 \\
(1,89)\end{array}$ & $\begin{array}{l}128,0 \\
(1,88)\end{array}$ & $\begin{array}{c}93,0 \\
(1,74)\end{array}$ & $\begin{array}{c}105,0 \\
(1,93)\end{array}$ & $\begin{array}{c}57,0 \\
(1,83)\end{array}$ & $\begin{array}{l}171,0 \\
(1,88)\end{array}$ \\
\hline 07 & $\begin{array}{l}465,0 \\
(1,88)\end{array}$ & $\begin{array}{c}166,0 \\
(1,80)\end{array}$ & $\begin{array}{c}121,0 \\
(1,89)\end{array}$ & $\begin{array}{c}157,0 \\
(1,91)\end{array}$ & $\begin{array}{c}151,0 \\
(1,94)\end{array}$ & $\begin{array}{l}180,0 \\
(2,02)\end{array}$ \\
\hline 08 & $\begin{array}{l}360,0 \\
(1,88)\end{array}$ & $\begin{array}{l}134,0 \\
(1,83)\end{array}$ & $\begin{array}{c}55,0 \\
(1,86)\end{array}$ & $\begin{array}{l}116,0 \\
(1,93)\end{array}$ & $\begin{array}{l}100,0 \\
(1,89)\end{array}$ & $\begin{array}{c}98,0 \\
(2,09)\end{array}$ \\
\hline 09 & $\begin{array}{l}416,0 \\
(1,82)\end{array}$ & $\begin{array}{l}171,0 \\
(1,86)\end{array}$ & $\begin{array}{c}124,0 \\
(1,66)\end{array}$ & $\begin{array}{l}143,0 \\
(1,79)\end{array}$ & $\begin{array}{l}181,0 \\
(1,90)\end{array}$ & $\begin{array}{l}286,0 \\
(2,01)\end{array}$ \\
\hline 10 & $\begin{array}{r}2111,0 \\
(1,84)\end{array}$ & $\begin{array}{c}84,0 \\
(1,92)\end{array}$ & $\begin{array}{c}58,0 \\
(1,94)\end{array}$ & $\begin{array}{l}109,0 \\
(1,88)\end{array}$ & $\begin{array}{l}370,0 \\
(1,76)\end{array}$ & $\begin{array}{l}176,0 \\
(2,10)\end{array}$ \\
\hline
\end{tabular}




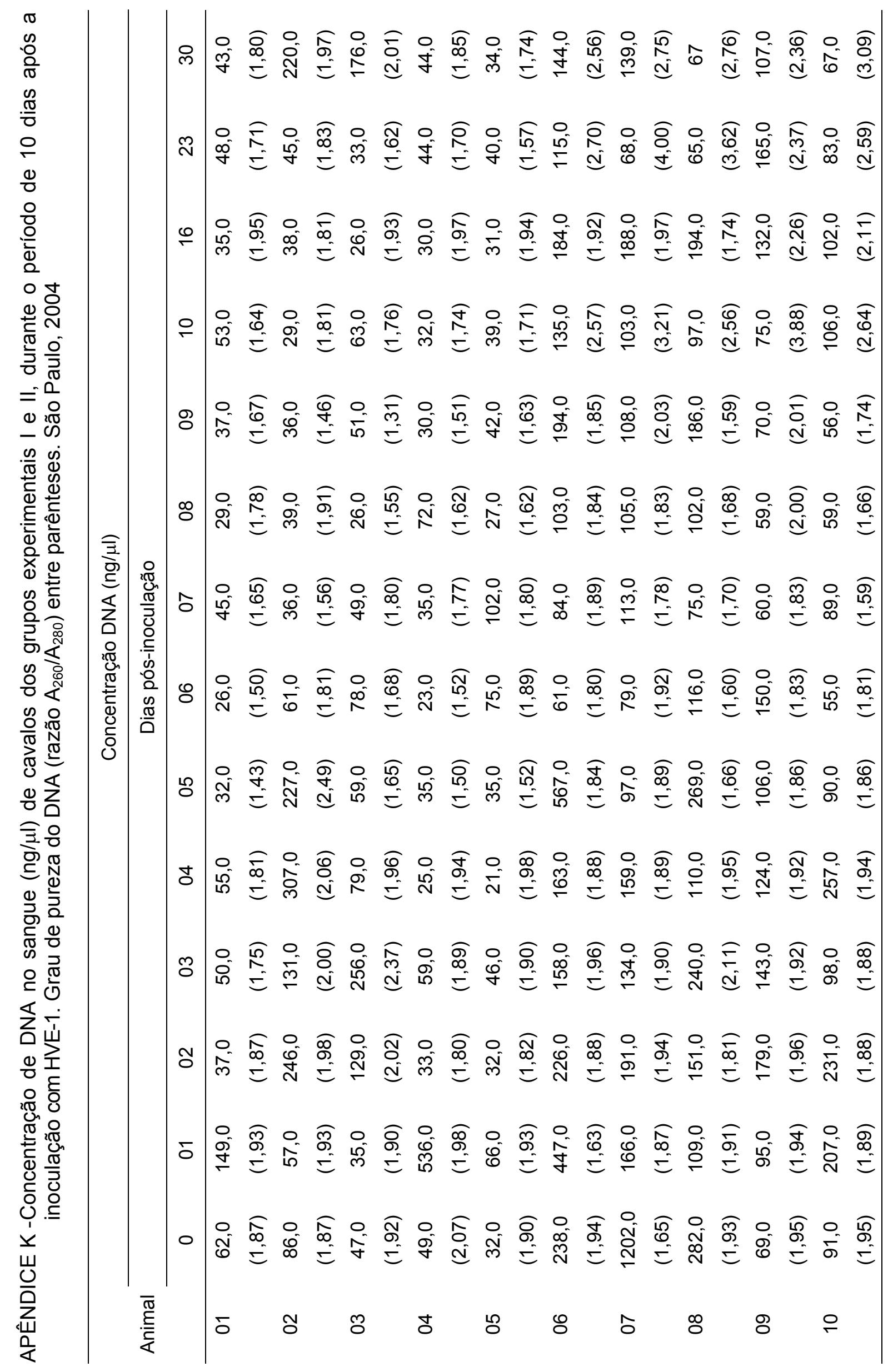


ANEXO A - Graduação da hiperplasia linfóide faringeana em cavalos avaliada por endoscopia, observando a variação na coloração, localização, tamanho e quantidade dos folículos linfóides no trato respiratório anterior

\begin{tabular}{|c|c|c|c|c|c|}
\hline \multirow[t]{3}{*}{ Grau } & \multicolumn{5}{|c|}{ Hiperplasia linfóide faringeana } \\
\hline & \multicolumn{4}{|c|}{ Folículos linfóides } & \multirow[t]{2}{*}{ Observações } \\
\hline & Coloração & Localização & Tamanho & Quantidade & \\
\hline 1 & Branca & Parede dorsal da faringe & Pequenos & Poucos & Folículos linfóides inativos \\
\hline 2 & $\begin{array}{l}\text { Branca ou } \\
\text { rósea }\end{array}$ & $\begin{array}{l}\text { Parede dorsal e lateral da } \\
\text { faringe e abertura das } \\
\text { bolsas guturais }\end{array}$ & Variáveis & Muitos & $\begin{array}{l}\text { Folículos linfóides inativos } \\
\text { intercalados com ativos }\end{array}$ \\
\hline 3 & $\begin{array}{l}\text { Branca ou } \\
\text { rósea }\end{array}$ & $\begin{array}{c}\text { Parede dorsal e lateral da } \\
\text { faringe e superfície dorsal } \\
\text { do palato mole }\end{array}$ & Grandes & Muitos & $\begin{array}{l}\text { Hiperplasia do epitélio tonsilar } \\
\text { faringeano }\end{array}$ \\
\hline 4 & Rósea & $\begin{array}{c}\text { Toda a superfície da } \\
\text { faringe, superfície dorsal } \\
\text { palato mole, superfície da } \\
\text { epiglote e abertura da } \\
\text { bolsa gutural }\end{array}$ & Grandes & Muitos & $\begin{array}{c}\text { Pólipos de tecido linfóide no } \\
\text { recesso faríngeo ou parede lateral } \\
\text { ou dorsal da faringe }\end{array}$ \\
\hline
\end{tabular}

Fonte dos dados brutos: Raker (1982)

ANEXO B - Valores de referência do leucograma de cavalos adultos (acima de 5 anos de idade) expressos em média \pm desvio padrão do número de células $/ \mathrm{mm}^{3}$ (valor absoluto)

\begin{tabular}{|c|c|c|c|c|c|c|}
\hline \multirow[b]{2}{*}{$\begin{array}{l}\text { Leucócitos } \\
\text { Totais } \\
\left(\times 10^{3} / \mathrm{mm}^{3}\right)\end{array}$} & \multicolumn{6}{|c|}{ Leucócitos } \\
\hline & $\begin{array}{l}\text { Neutrófilos } \\
\text { Bastonetes } \\
\left(\times 10^{1} / \mathrm{mm}^{3}\right)\end{array}$ & $\begin{array}{l}\text { Neutrófilos } \\
\text { Segmentados } \\
\left(\times 10^{3} / \mathrm{mm}^{3}\right)\end{array}$ & $\begin{array}{l}\text { Linfócitos } \\
\left(\times 10^{3} / \mathrm{mm}^{3}\right)\end{array}$ & $\begin{array}{l}\text { Monócitos } \\
\left(\times 10^{2} / \mathrm{mm}^{3}\right)\end{array}$ & $\begin{array}{l}\text { Eosinófilos } \\
\left(\times 10^{2} / \mathrm{mm}^{3}\right)\end{array}$ & $\begin{array}{c}\text { Basófilos } \\
\left(\times 10^{1} / \mathrm{mm}^{3}\right)\end{array}$ \\
\hline $8,822 \pm 1,760$ & $2,200 \pm 5,700$ & $4,877 \pm 1,316$ & $3,146 \pm 0,826$ & $3,850 \pm 2,400$ & $3,160 \pm 2,310$ & $6,000 \pm 7,200$ \\
\hline
\end{tabular}

Fonte dos dados brutos: Jain (1986)

ANEXO C - Valores de referência de células provenientes do lavado broncoalveolar de cavalos adultos clinicamente sadios expressos em média \pm desvio padrão da porcentagem de macrófagos, linfócitos, neutrófilos, eosinófilos e mastócitos

\begin{tabular}{ccccc}
\hline Macrófago & Linfócito & Neutrófilo & Eosinófilo & Mastócito \\
\hline $54,78 \pm 15,92$ & $33,70 \pm 14,41$ & $9,76 \pm 7,43$ & $0,98 \pm 2,46$ & $0,78 \pm 1,21$
\end{tabular}

Fonte dos dados brutos: Fernandes, Mori, Sanches (2000) 
ANEXO D - Valores normais de freqüência cardíaca, respiratória e temperatura corpórea em cavalos adultos

\begin{tabular}{ccc}
\hline Freqüência cardíaca & Freqüência respiratória & Temperatura corpórea \\
\hline $30-40$ b.p.m. & $18-20$ m.r.m. & $38,0 \pm 1,0^{\circ} \mathrm{C}$ \\
\hline
\end{tabular}

b.p.m.: batimentos cardíacos por minuto. m.r.m.: movimentos respiratórios por minuto Fonte dos dados brutos: Speirs (1997) 